\title{
Geology and Ore Deposits of the Cuyuna North Range Minnesota
}

GEOLOGIGAL SURVEY PROFESIIONAL PAPER 407

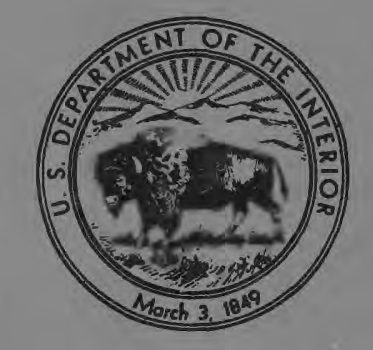


Geology and Ore Deposits of the Cuyuna North Range

Minnesota

$B y$ ROBERT GORDON SCHMIDT

GEOLOGICAL SURVEY PROFESSIONAL PAPER 407

The occurrence and origin of Precambrian iron ore and manganiferous iron ore

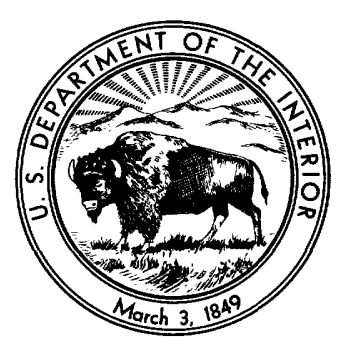

UNITED STATES GOVERNMENT PRINTING OFFICE, WASHINGTON : 1963 
UNITED STATES DEPARTMENT OF THE INTERIOR

STEWART L. UDALL, Secretary

GEOLOGIGAL SURVEY

Thomas B. Nolan, Director

The U.S. Geological Survey Llbrary has cataloged this publication as follows:

Schmidt, Robert Gordon, 1924-

Geology and ore deposits of the Cuyuna North range, Minnesota. Washington, U.S. Govt. Print. Off., 1963.

v, 96 p. illus., maps, diagrs., tables and portfolio (col. maps, diagrs. (part col.)) $29 \mathrm{~cm}$. (U.S. Geological Survey. Professional paper 407)

Bibliography : p. 87-91.

1.Geology-Minnesota-Cuyuna North range. 2.Ore-deposits-Minnesota-Cuyuna North Range. 3.Iron ores-Minnesota-Cuyuna North range. I.Title: The Cuyuna North range, Minnesota. (Series)

For sale by the Superintendent of Documents, U.S. Government Printing Office Washington 25, D.C. 


\section{CONTENTS}

Abstract

Introduction

History of the district.

Previous geologic investigations

Present investigation . . . . . .

Acknowledgments.

General geology . . . . . . .

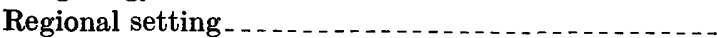

Cuyuna district.......

Sedimentary rocks.

Mahnomen formation . .

Mahnomen No. 1 mine

Mahnomen No. 3 mine..................

Other exposures and drill hole sections of the

Mahnomen formation.

Trommald formation

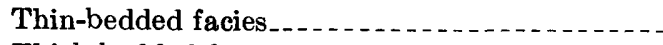

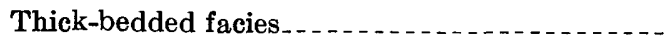

Clastic material included in the Trommald formation. . . . . .

Sandy layers in the Trommald formation. -

Argillaceous layers in the thin-bedded facies.

Rabbit Lake formation

Black argillite and slate. . . . . . . . . . . . .

Upper iron-formation lenses...............

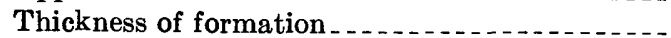

Chlorite and chlorite-biotite schists . . . ......

Conditions of sedimentation in the Cuyuna district.-

Mahnomen formation. ........

Trommald formation

Source of iron-rich sediments and conditions of sedimentation..........................

Rabbit Lake formation

Correlation of the Cuyuna sequence..............

Comparison of the proposed stratigraphic section and others formerly described....

North range

South range.

Correlation with the Emily and Mesabi districts

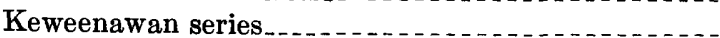

Cretaceous system . . . .

Pleistocene series

Igneous rocks

Dike rocks

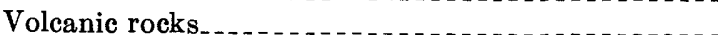

Veins and fracture fillings.

Structural features.

Folds

Faults

Metamorphism

Sedimentary rocks . . . . . . . . . .

Igneous rocks.
Page
Mineral deposits

Iron ores and manganiferous iron ores........... 48

Iron-ore minerals . . . . . .

Manganese-ore minerals _................. 48

Miscellaneous minerals ................. 49

Classification of ore .

Commercial grades of ore ............... 49

Types of ore observed in the field........ 49

Laminated ore

Gnarled ore

Bedded wash ore $\ldots \ldots$

Wash ore with conspicuous replacement

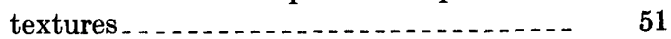

Specular ore

Cindery and massive ore

Solution-banded ore

Distribution of types relative to facies........... $\quad 53$

Distribution of manganese in the iron-formations . - $\quad 53$

Distribution of phosphorus in the Trommald formation

Magnetic attraction as related to the iron-formation $\quad 55$

Origin and occurrence of ore $\ldots \ldots$

Relation of major ore bodies to geologic features $\quad 57$

Occurrence of ore in the Trommald formation _- $\quad 57$

Thin-bedded facies.... 57

Distribution of ore minerals and ore

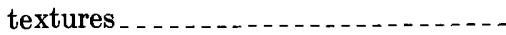

Relative time of formation........

Shapes of brown ore bodies and relation to unoxidized iron-formation

Association of brown ore with nontronitic iron-formation............ Red-brown ores

Relation of ore to structure in the thinbedded facies...........................

Boron content related to origin of ore

Thick-bedded facies..................

Occurrence of ore in upper iron-formation within

the Rabbit Lake formation....... 61

Suggested origin

Recommendations for further exploration

Thin-bedded facies

Thick-bedded facies $\ldots \ldots$

Exploration for manganiferous ores. 64

Low-grade manganese reserves . . . . . . . . . . . . 64

Description of mines

Kennedy mine

Rabbit Lake mine.

Northland mine

Milford mine

Preston mine

Gloria mine

Algoma mine 
Description of mines-Continued

Ferro mine

Joan No. 4 mine-

Merritt mine

Pontiac mine

Joan No. 3 mine

North Yawkey mine

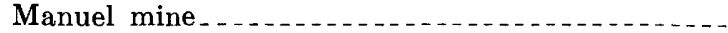

Croft mine

Meacham mine

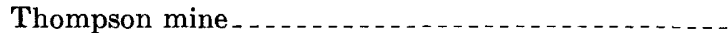

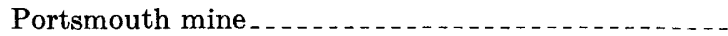

Armour No. 2 mines . . . .

Armour No. 1 mine

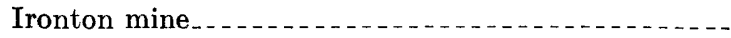

Bonnie Belle mine

Pennington mine

Feigh mine

South Hillcrest mine

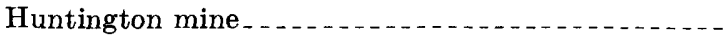

Martin mine

Mangan No. 2 mine

\begin{tabular}{|c|c|c|}
\hline Page & Description of mines-Continued & Page \\
\hline 68 & Mahnomen No. 1 mine & 78 \\
\hline 69 & Mahnomen No. 3 mine & 79 \\
\hline 69 & Hillcrest Extension mine & 79 \\
\hline 69 & Mahnomen No. 4 mine & 79 \\
\hline 69 & Sultana-Hopkins mine & 80 \\
\hline 69 & Louise mines. & 80 \\
\hline 69 & Mahnomen No. 2 mine & 81 \\
\hline 70 & ine $_{-\ldots}$ & 81 \\
\hline 70 & Alstead-North Hillcrest mine & 82 \\
\hline 71 & Mangan No. 1 mines.............. & 82 \\
\hline 71 & Joan No. 1 mines & 83 \\
\hline 72 & Maroco mine & 84 \\
\hline 73 & ine & 84 \\
\hline 74 & ne & 84 \\
\hline 74 & - - & 85 \\
\hline 74 & Carlson-Nelson mine & 85 \\
\hline 75 & - & 85 \\
\hline 76 & ine $_{-1}$ & 85 \\
\hline 76 & Sagamore mine and the Syracuse property & 86 \\
\hline 77 & ted references & 87 \\
\hline 77 & $-\ldots . .-1$ & 93 \\
\hline
\end{tabular}

\section{ILLUSTRATIONS}

Plate 1. Regional bedrock geologic map of central Minnesota.

2. Bedrock geologic map of the North range, Cuyuna district, Minnesota.

3. Detailed geologic map and sections of the Crosby-Ironton-Trommald area.

4. Detailed geologic map and sections of the Rowe-Sagamore mine area.

5. The North range, Cuyuna district, showing distribution of the thin-bedded and thick-bedded facies of the Trommald formation and the total thickness of the Trommald formation.

6. Stratigraphic sections of the middle Precambrian rocks of the Cuyuna North range showing changes of facies and thickness in the Trommald formation.

7. Bedrock geologic map of Feigh-Pennington-Armour mines area showing geologic contacts previous to mining and positions of sections on plate 8 .

8. Isometric sections in the Feigh-Pennington-Armour mines area.

9. Generalized distribution of manganese in the Trommald formation, Cuyuna North range.

10. Approximate outlines of ore mined from the thin-bedded facies of the Trommald formation.

11. Approximate outlines of ore mined from the thick-bedded facies of the Trommald formation.

FIGURE 1. Index map showing location of North range, Cuyuna district

2. Unoxidized thin-bedded Trommald formation, northwest side of Portsmouth mine, SE $1 / 4$ SE $1 / 4$ sec. 2 , T. 46 N., R. 29 W

3. Straight-bedded subfacies, thick-bedded Trommald formation, northeast end of Joan No. 1 mine $\ldots$

4. Wash ore in wavy-bedded subfacies, thick-bedded Trommald formation, southwest end of Joan No. 1 mine ....

5. Single bed of mottled chert, straight-bedded subfacies, thick-bedded Trommald formation, Joan No. 1 mine.....-

6. Light-brown titaniferous ferruginous slate from lens in Trommald formation, with radiating sheaves of tourmaline crystals. Portsmouth mine, sec. 11, T. 46 N., R. 29 W.

7. Thin-bedded magnetite-silicate iron-formation and crosscutting layer of iron-formation breccia with titaniferous matrix

8. Titania content of the Precambrian rocks in a part of the North Range, Cuyuna district

9. View in Virginia mine looking southwest and showing intricate folding in argillaceous siliceous upper iron-formation interbedded in the Rabbit Lake formation.

10. Bedded biotite-chlorite schist at the base of the Rabbit Lake formation in open folds on the south side of the Pennington mine, looking west

11. Alumina-titania ratios in 40 samples of iron-formation and associated rocks, Cuyuna district.

12. Tabulation of data from exploration drilling in the NE1/4NE1/4 sec. 32, T. 47 N., R. 29 W

13. Polished and striated roches moutonnée of unoxidized thin-bedded Trommald formation exposed by stripping of glacial drift in Arko mine.

14. Tuffaceous layer overlying a light-colored bed of titaniferous argillite, Maroco mine

15. Stilpnomelane-quartz vein cutting silicate-rich thin-bedded Trommald formation, North Hillcrest mine.......-

Page 
16. Brown columnar gnarled ore, Sagamore No. 2 mine

17. Idealized vertical section showing narrow zone of red oxidized iron-formation along joints and later associated brown oxidized iron-formation

18. Vertical alteration content of gnarled ore on the left and partly oxidized nontronitic iron-formation on the right, thin-bedded Trommald formation, Sagamore No. 2 mine

19. Drag-folded cherty thin-bedded Trommald formation showing textures caused by local migration of iron and replacement of quartz, Armour No. 2 open-pit mine.

20. The Mahnomen No. 1 mine, looking northeast

21. Brown gnarled ore occurring beneath unoxidized thin-bedded Trommald formation, Sagamore No. 2 mine $\ldots . .$.

\section{TABLES}

TABLE 1. Chemical analyses of two samples from the Mahnomen formation

2. Analyses of minor constituents of Cuyuna district rocks

3. Chemical analyses of 18 samples from the unoxidized thin-bedded facies of the Trommald formation..........

4. Chemical analyses of samples of partly altered iron-formation and ores from the thin-bedded facies of the Trommald formation . .

5. Chemical analysis of channel sample 937 from the thick-bedded facies of the Trommald formation

6. Chemical analyses of seven samples of miscellaneous rocks from the Cuyuna district

7. Chemical analyses of eight samples of rocks in the Rabbit Lake formation.

8. Average analyses of grades of Cuyuna North range ore

9. Changes in phosphorus content produced by alteration of the thin-bedded facies of the Trommald formation to ore

10. Boron and germanium content of unoxidized thin-bedded facies of the iron-formation in the Trommald formation and stratigraphically equivalent ores in the formation.

11. Production of iron ore, manganiferous iron ore, and ferruginous manganese ore from mines in the Cuyuna district, 1911-54 


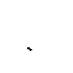

. 


\title{
GEOLOGY AND ORE DEPOSITS OF THE GUYUNA NORTH RANGE, MINNESOTA
}

\author{
By Robert Gordon Schmidt
}

\begin{abstract}
The Cuyuna North range in central Minnesota produces iron ore and manganiferous iron ore from several types of sedimentary iron-formation of probable Animikie age. The iron-formation is in a tightly folded weakly metamorphosed sequence of generally argillaceous rocks.
\end{abstract}

The Cuyuna district is divided into two or three smaller areas. The study described here was limited to an area of about 50 square miles called the North range in which most of the ore has been produced, and in which all the currently operating mines are located. A much larger part of the district, the South range, was only briefly studied. The Emily district, which is 8 to 20 miles north of the North range and is included in the Cuyuna district by most other authors, lies between the Cuyuna and the Mesabi districts. The Emily district has been extensively explored, but no mines have been opened there.

The Cuyuna district was discovered in 1904 when the first merchantable ore was penetrated during exploratory drilling that was prompted by many conspicuous magnetic anomalies. Ore shipments were begun in 1911 and have generally increased, except during the pronounced economic depression periods in the early 1920 's and 1930 's. A record of $3,875,125$ gross tons was produced in 1953 . Total shipments from the district through 1954 were $82,783,778$ tons of all types of direct-shipping ore and concentrates; production at present is 2 to 3 million tons per year.

The rocks in the North range consist of a sequence of three sedimentary formations, tightly folded and intruded locally by large dikes of mafic composition. The sedimentary rocks and intrusives have been metamorphosed into the biotite and chlorite zones. The bedrock in the Cuyuna district is covered by Pleistocene glacial drift, except for natural outcrops in two places in the South range. The paucity of outcrops makes it very difficult to study the relation of the Cuyuna rocks to other rocks of central Minnesota. The three Cuyuna North range formations probably also occur in the South range and occupy a northeastward-trending basin, more than 70 miles long and about 15 miles wide, surrounded by older granites and metamorphosed sedimentary rocks. They are probably equivalent to the sedimentary rocks in the Emily district which, in turn, are probably correlative with the Animikie rocks of the Mesabi district. Lower or middle Precambrian granites occur along most of the southeast side of the basin; information is sparse or lacking in the other directions.

The metamorphosed sedimentary rocks in the North range have been divided into three conformable formations; from oldest to youngest, they are the Mahnomen, Trommald, and Rabbit Lake. Neither the bottom nor the top of the succession has been found. The Mahnomen formation is at least 2,000 feet thick and consists of generally well sorted fine clastic material that is low in iron, and locally includes quartzitic lenses near the top.

The Trommald formation consists almost entirely of ironformation of varied mineral composition and texture, and it ranges in thickness from 45 to more than 500 feet. The formation has a thin- and thick-bedded facies which have characteristic compositional and textural differences. In parts of the North range, the entire Trommald formation is the thinbedded facies; in others, the formation is all the thick-bedded facies; and in about one-third, the thin-bedded underlies the thick-bedded and grades upward into it. The thin-bedded facies generally corresponds to the carbonate or silicatecarbonate facies, and the thick-bedded facies resembles the oxide facies as described by James in 1954. The thin-bedded facies includes a few local thin layers containing abundant quartz sand and local argillaceous lenses that are probably tuffaceous.

The Rabbit Lake formation is largely gray and black partly ferruginous argillite and slate at least 2,000 feet thick and contains lenses of lean siliceous argillaceous iron-formation. The lowermost 300 feet of the formation contains about 2.0 percent titania in contrast with 0 to 1.0 percent in the rest of the formation and averages of 0.5 percent in the Mahnomen formation and 0.2 percent in the Trommald formation. The titaniferous zone at the base of the Rabbit Lake formation has been found in almost all parts of the North range and at the northeast end of the South range, which was the only place tested in that range. In part of the North range, the base of the formation includes as many as three basaltic flows or sills and probably also beds of water-laid tuff.

Thin horizontal Keweenawan flows have been reported in a small area of the South range, but have not been observed in the North range. If their assumed age is correct, the flows indicate that the generally horizontal bedrock erosion surface was formed during or before Keweenawan time. The surface was subjected to deep weathering, and thick saprolites including iron ores were developed on those rocks that were profoundly affected by surface conditions; the argillites and slates were little changed. The relationship of the Keweenawan flows to this period of weathering was not studied.

Horizontal conglomerates overlying the eroded Precambrian surface have been called Cretaceous in the past because of their resemblance to conglomerates of Cretaceous age in the Mesabi district, but are actually consolidated Pleistocene gravels. The deeply weathered low-relief surface of the Precambrian rocks was vigorously scoured by Pleistocene continental glaciation, which was followed by the deposition of stratifled and unstratifled drift to depths of 15 to more than 200 feet in the North range. The present topographic surface is entirely the result of the last Pleistocene deposition and does not seem to reflect the gentle configuration of the underlying bedrock surface. 
GEOLOGY AND ORE DEPOSITS OF THE CUYUNA NORTH RANGE, MINNESOTA

Clastic sedimentation of clay and silt, which was relatively free of iron, preceded deposition of the Cuyuna iron-formation and produced the Mahnomen formation, which is probably more than 2,000 feet thick. A sharp contact separates the chemical sediments of the Trommald formation, which consists of chert and iron oxides, silicates, and carbonates. The iron-rich chemical precipitates were deposited in two general marine or lacustrine environments. Deep quiet reducing water yielded the thin-bedded facies that consists of chert, carbonates, and silicates corresponding to the carbonate and carbonate-silicate facies defined by James. Shallower, probably agitated, oxidizing water yielded the thick-bedded facies that consists of chert and iron oxides, the oxide facies of James. The thick-bedded facies covered about one-third of the area of Trommald formation deposition in the North range at the beginning of deposition and gradually spread over the thin-bedded facies as iron-formation accumulated until it covered about two-thirds of the area of deposition at the end of Trommald time. Manganese was deposited most abundantly in a zone near the transition between the facies.

The deposition of the Trommald formation was terminated abruptly by an infiux of clay and silt and, locally, tuff and flows into the sedimentary basin. The bottom waters became stagnant and the Rabbit Lake formation, which consisted of more than 2,000 feet of gray and black muds, was laid down. Iron deposition continuęd, probably as siderite and pyrite. Locally, chert and iron minerals were precipitated in sufficient abundance to produce lenses and layers of lean argillaceous iron-formation.

Study of the North range has produced a stratigraphic column and an areal geologic map different in many respects from those of previous authors, particularly Grout and Wolff. The proposal that nearly all the Cuyuna ores occur in one unit, the Trommald formation, which is less than 45 feet to more than 500 feet in thickness and generally from 100 to 400 feet, is in sharp contrast to the 2,575- to 3,465-foot orebearing unit described by Wolff.

The three sedimentary formations have been intruded by mafic rocks that appear sill-like in limited areas but that generally cut across all the stratigraphic units to form a discontinuous group of dikes in a belt at least 6 miles long and half a mile wide along the southeast edge of the North range. The dikes roughly parallel the fold axial planes and were probably injected during or after folding.

The sedimentary rocks of the district have been tightly folded into northeastward-trending folds that are generally overturned to the northwest and are locally isoclinal. The folds plunge both northeast and southwest. About half of the bedrock in the North range is Mahnomen formation; the Trommald and Rabbit Lake formations occur as synclines downfolded into it. A few minor faults were mapped in the mines and a larger fault was inferred at the southwest end of the Sagamore mine, but no major faults were detected. Evidence was not found to substantiate the major faults described by Wolff.

The argillaceous sedimentary rocks, iron-formations, and mafic dikes have been metamorphosed in the chlorite or biotite zone in most of the North range, and definitely in the biotite zone in a few places along the southeast edge of the range. The most abundant minerals in the argillites and slates are muscovite and quartz; in the thin-bedded facies of the Trommald formation, quartz, ferrous and manganous carhonate, minnesotaite, and stilpnomelane; in the basalt fiows, chlorite and epidote; and in the mafic dikes, chlorite, epidote, clinozoisite, albite or oligoclase, and calcite. The grain size of recrystallized chert was used as an index of metamorphic grade in the thick-bedded facies of the Trommald formation and in the upper iron-formation within the Rabbit Lake formation, both of which generally contained no minerals indicative of metamorphic grade.

The iron ore and manganiferous iron ore of the North range occur almost entirely in the Trommald formation; only a minor amount has formed in the upper iron-formation of the Rabbit Lake formation, and the stratigraphic position of the ore in the small Snowshoe mine could not be determined. The ore occurs as residual concentrations of porous or vuggy iron and manganese oxide minerals and quartz that remain after carbon dioxide, magnesia, and part of the quartz have been removed by oxidizing and leaching waters. Both directshipping ores and those requiring treatment to remove some of the remaining quartz are produced in the district, and the production of concentrates somewhat exceeds direct-shipping ore at present. The type of ore is related to the formation and facies in which it is developed. Direct-shipping ores occur mostly in the thin-bedded facies of the Trommald formation; concentrating ores are also abundant in this unit, but constitute most of the production from the thick-bedded facies and from the upper iron-formation in the Rabbit Lake formation. Manganiferous iron-formation occurs in both the Trommald and Rabbit Lake formations, but it is more abundant in the Trommald formation. In the Trommald it is generally within or close to the area in which the thin- and thick-bedded facies overlap; locally, it is most abundant in a particular stratigraphic zone, though the zones are in different positions in different parts of the district. The highest grade manganese ores, which formerly were selectively mined by underground methods, were within or near the zone of transition from the thin- to the thick-bedded facies.

The phosphorus in the Cuyuna ores was largely or wholly derived from the parent iron-formation rather than introduced during or after the development of ore. In some places, chemical analyses showed that the phosphorus is greater in the ore than in the original iron-formation; in other places, less phosphorus is present. The range of phosphorus content in the iron-formation is from a trace to several percent in unoxidized and in oxidized and leached phases. Low phosphorus analyses in the unoxidized rock correspond to low analyses in adjacent oxidized iron-formation and ore; similarly, where the parent rock is high in phosphrous, oxidized iron-formation derived from it is also high in phosphorus.

Most of the information regarding the origin of the North range ores was obtained from the thin-bedded facies of the Trommald formation, and the discussions of origin apply principally to that unit. The ores in the thin-bedded facies, and perhaps in all the iron-formation, formed in two stages.

During the first stage, warm or hot water, which was possibly mostly ground water heated and caused to circulate with greater vigor by the admixture of magmatic emanations, widely oxidized the iron-formation in part of the district and leached some of the oxidized iron-formation to ore. The resultant ore bodies are red brown and largely hematitic; they are tabular or lenticular, generally in the plane of the bedding, and some of them are known to extend many hundreds of feet below the bedrock surface. These ore bodies, which seem to be accompanied by a relatively large amount of oxidized hematitic marginal ore, contain consistently more boron than the ores formed in the second stage and more boron than occurs in the unaltered iron-formation. All the largest mines 
in the district include or consist entirely of ore bodies of this type.

The second stage of ore concentration occurred when all the rocks were subjected to very deep surface weathering. Goethitic ores were formed as irregular blankets over exposures of the thin-bedded facies, and possibly most of the ores in the thick-bedded facies and in the upper iron-formation lenses of the Rabbit Lake formation were also formed at this time. Brown iron oxides and ore were formed on almost all residual masses of unoxidized iron-formation that remained within the earlier altered hematitic iron-formation. Where the porous hematitic ores extended downward for several hundred feet and unoxidized iron-formation remained nearby, the existent ore served as a channelway for the weathering solutions to form brown ore at seemingly anomalous great depths. Some of the large ore bodies, of which the best example is at the Sagamore mine, formed in this twostage manner. Weathering solutions also oxidized and leached the iron-formation preferentially where joints perpendicular to the fold axes were abundant and to a minor extent along the sides of shattered mineral-filled veins.

The Trommald formation deserves further exploration for ore in certain limited areas in the North range. The thickbedded facies may be explored for local bodies of wash ore any place the facies is known to occur. The thin-bedded facies occurs more extensively than the thick-bedded facies, but should be explored for wash ores and direct-shipping ores only in a mile-wide belt along the southeast edge of the range. No further exploration of iron-formation within the Rabbit Lake formation is recommended.

Manganiferous ores are most apt to be found where the thin-bedded facies occurs alone and in both facies near the facies overlap. The rich ferruginous manganese ores, which were largely mined selectively by underground methods, occurred near the facies transition.

The marginal ores and the unoxidized iron-formation of the Cuyuna district have been considered as a source of large quantities of manganese, particularly in a national emergency. In 1951, Lewis made an estimate of 500 million minable tons that contained more than 2 percent manganese, including unoxidized iron-formation and marginal ores in the North range and ferruginous slate in western Aitkin County.

The last part of the report is a series of descriptions of individual mines in the Cuyuna North range.

\section{INTRODUCTION}

The Cuyuna iron-ore district is near the geographic center of Minnesota in Morrison, Crow Wing, and Aitkin Counties (fig. 1). The district is about 68 miles long, and extends from Randall in Morrison County northeastward to a point 11 miles east of the small community of Hassman in Aitkin County. The width of the district ranges from less than 1 mile near the northeast end to more than 10 miles where the North and South ranges are continguous, or to more than 25 miles if the Emily district in northern Crow Wing County is included.

The Cuyuna district is traditionally divided into three general subdistricts or ranges-the South range, the North range, and the area that the writer prefers to designate as the separate Emily district. The
Cuyuna South range is a long narrow area (fig. 1) extending the full length of the district; it is less than 1 mile to 7 miles or perhaps 11 miles wide, depending upon the validity of some of the little-known outlying belts of iron-formation. The South range was the site of much early exploration and several underground mines, now all abandoned. Recently one small open-pit mine, the Gorman, was operated near Randall in Morrison County. The South range has attracted a moderate amount of exploratory drilling in recent years, but most exploration has been concentrated in the North range and in the Emily district.

The North range (fig. 1), a much smaller area about 12 miles long and 5 miles wide, is near the villages of Crosby and Ironton in Crow Wing County, includes all current mining activity, and is the area studied in this survey.

Northwest of the Mississippi River in the northern part of Crow Wing County is the Emily district (fig. 1), where small amounts of exploration had been carried on for many years, and a large amount of both drilling and geophysical exploration have been conducted since about 1950. Geographic boundaries can scarcely be placed on the Emily district, for the continuance of exploration has steadily expanded the area known to be underlain by iron-formation; and it is possible that future exploration will connect the district with the Cuyuna North range at the south and the Mesabi district at the northeast (pl. 1).

Iron-bearing rock possibly related geologically to the rocks of the Cuyuna district has also been found near Philbrook in Todd County to the west.

The Cuyuna district, unlike other iron-bearing districts in the Lake Superior region, is in a generally flat area almost entirely covered by a thick mantle of Pleistocene glacial drift. Outcrops occur in the near vicinity of the iron-formation only in Todd and Morrison Counties and at one place in Aitkin County. The topography of the district is dominated by features developed by the retreating continental glacial ice and is a poorly drained morainic surface of irregular hills and many lakes and swamps. Part of the area is relatixely level outwash plain. The area is drained by the Mississippi River, which passes directly through the district from near the northeast end at Hassman southwestward past Aitkin, Riverton, and Brainerd to Fort Ripley. The extremes in altitude in the area are 1,150 and 1,450 feet above sea level. Natural altitudes in the North range are from 1,172 to 1,390 feet above sea level, but most of the bigger hills have less than 100 feet of relief. In contrast with the natural topography, some of the open-pit mines 


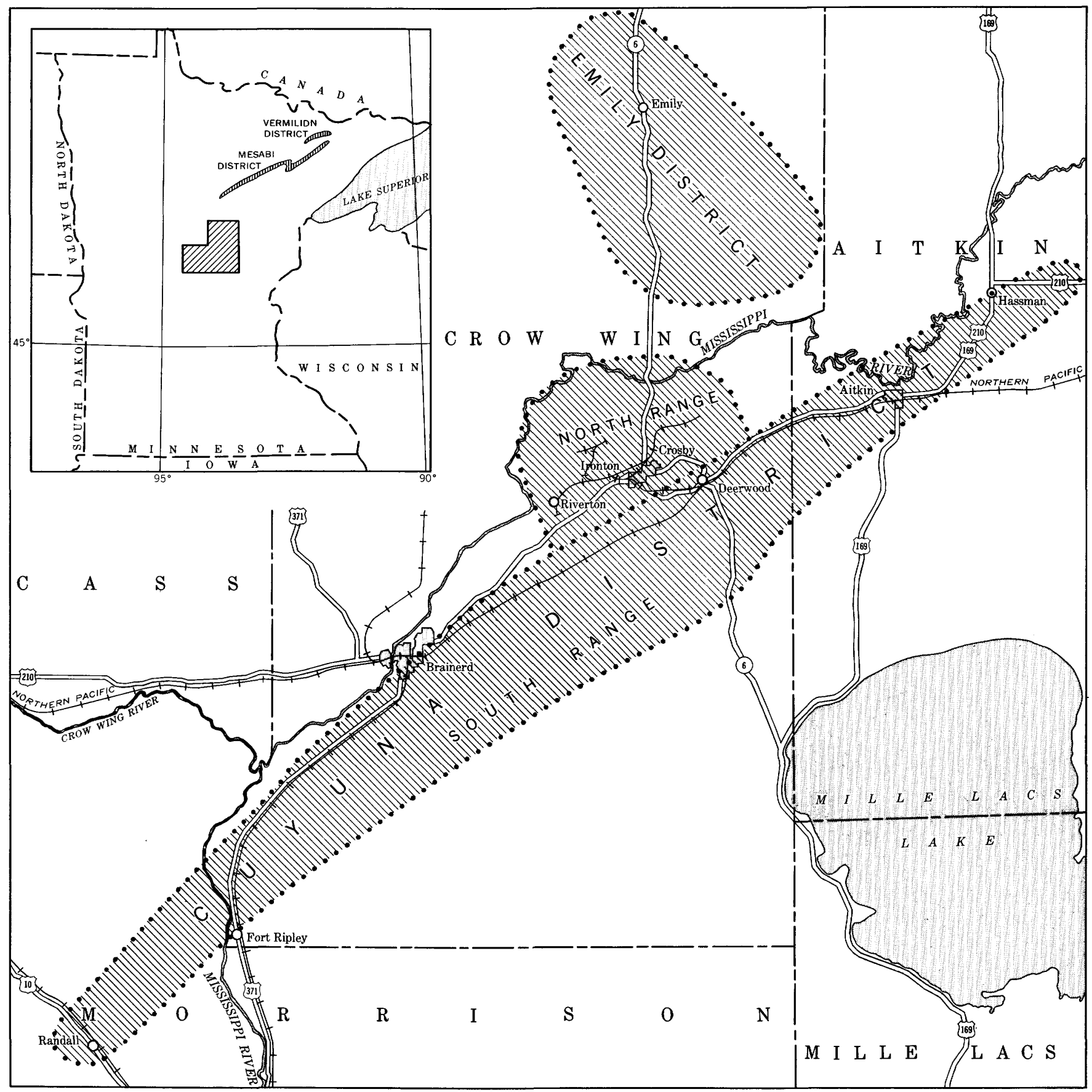

Frgure 1.-Index map showing location of North range, Cuyuna district. 
are more than 350 feet deep, and some stripping and lean ore dumps are more than 150 feet high, which has resulted in a manmade relief of 500 feet. Of course the open pits lack natural drainage, and when pumping of ground water stops they soon fill to within a few tens of feet below the surface.

All the communities in the North range are incorporated as villages. Crosby and Ironton are immediately adjacent and form the most important business and residential center of the area studied. Cuyuna, Manganese, Trommald, and Riverton, like Crosby and Ironton, have been built since the development of mining in the district, but they have declined in population and in importance as more rapid transportation has permitted consolidation of most of the mining and business community into one center at Crosby and Ironton. According to 1950 census figures, the population of Crosby was 2,777; Ironton, 828; Cuyuna, 112; Manganese, 41; Trommald, 117; and Riverton, 148.

The area south of Crosby and Ironton is farmland and second-growth forest; north of the villages farming is less important and much of the land is included within State forests. Timber products are an important source of income. Many of the lakes are surrounded by summer homes and cottages, and services for tourists form a thriving industry in the area.

The North range is served by good highways and railroads capable of handling the heavy freight load imposed by the shipping of the Cuyuna iron ores (fig. 1). The main highway, U.S. 210, is a modern concrete road extending generally east-west. From Crosby it leads 15 miles southwest to Brainerd, a city of 12,637. Eastward it passes through Deerwood and Aitkin and extends to Duluth, 102 miles distant; at Aitkin it connects with U.S. 169, the main road linking this area with the Mesabi district. State Highway 6 extends northward from Crosby and southward from Deerwood. In earlier years, the range was served by separate lines of the Northern Pacific Railway and the Minneapolis, St. Paul \& Sault Ste. Marie RR. At present the railroads within the range are jointly operated by the two companies, and all trains serve Crosby and Ironton over the Northern Pacific tracks through Deerwood.

\section{HISTORY OF THE DISTRICT}

The Cuyuna district, its iron-formation hidden by glacial drift, was the last major iron-ore district discovered in the part of the Lake Superior region in the United States. In 1859, land surveyors laying out section lines in the northern part of T. 45 N., R. 29 W., noted deflection of the magnetic compass and wrote that "there was very great locäl attraction caused by Bog Iron in the low marshes" (Himrod, 1940, p. 3). Eli Griffin is reported to have been the first person to trace systematically the lines of magnetic attraction in the district. He spent much time doing this during 1875 and 1876 , but he was unable to obtain capital for subsurface exploration (Himrod, 1940, p. 4).

In 1882, Henry Pajari saw pieces of iron ore in the glacial drift along the railroad near Deerwood. He had had experience in the iron mines near Michigamme, Mich., and as a compassman for C. R. Van Hise in Michigan and Wisconsin. Convinced that iron ore was nearby, Pajari began explorations with a dip needle, and is said to have found areas of magnetic anomaly on both the North and the South ranges (Zapffe, 1938, p. 24). He tried to reach bedrock by sinking test pits, seemingly only in an area midway between the ranges; but the pits all went below the water table long before reaching bedrock, and he was forced to abandon the venture (Himrod, 1940, p. 4-7, 149-150).

On July 9, 1889, C. R. Van Hise made the following entry in his field notebook ${ }^{1}$ at St. Paul, Minn.:

Mr. Hopewell Clark, Land Commissioner of the St. Paul and Duluth Ry. informs me that an outcrop of granite has been found upon the northeast shore of Mille Lacs. Some distance northeast of this point, well up towards Rice Lake, 2 he also reports that there are numerous large angular blocks of a rock which he calls a quartzite, which he believes to represent an exposure. He also reports that between Mille Lacs and the line of the Northern Pacific ${ }^{3}$ is a line of magnetic attractions which has been traced for miles. Another line of attractions has been formed north and east of Mille Lacs and north of the Pacific road. Is it possible that these lines of attraction represent lower horizons of the Animikie formations which have not yet been discovered? If the supposed quartzite exposure is a bona fide one, this, combined with the attractions, would seem to indicate this.

A group of Brainerd men led by P. G. Fogelstrom drilled 1 hole 50 feet deep near Brainerd in 1893, but their hope of finding iron ore was unfulfilled (Himrod, 1940, p. 9-10).

About 1895 Cuyler Adams became interested in exploring for iron ore near Deerwood (Zapffe, 1938, p. 24). Adams made extensive surveys with a dip needle and mapped lines of maximum deflection. In May 1903, with W. C. White and W. D. Edson, he began drilling in the SE $1 / 4$ sec. 16, T. 46 N., R. 28 .W., and located lean ore later that year. H. B. Ayres began drilling in November 1903 and found lean ore in sec. 35, T. 47 N., R. 25 W., near Dam Lake in

\footnotetext{
1 C. R: Van Hise, unpublished field notes.

2 Probably the same Rice Lake shown on plate 1.

3 See fig. 1.
} 
CUYUNA NORTH RANGE, MINNESOTA

Aitkin County. By this time a great many people were interested in the search for ore in the area.

The first merchantable ore seems to have been discovered on the South range in the SE1/4NE1/4 sec. 20, T. 46 N., R. 28 W., in May 1904 (Himrod, 1940, p. 18). The drilling had been conducted by a partnership including Cuyler Adams, R. C. Jamieson, W. D. Edson, and others. Drilling was started on the North range in July 1904, in sec. 30 , T. 47 N., R. 28 W., near what was to become the Kennedy mine. The first hole was stopped by a boulder and the second penetrated good ore (Himrod, 1940, p. 18).

The name of the district, according to Himrod (1940, p. 20-21), was suggested by Mrs. Cuyler Adams from the first syllable of Cuyler and the name of Adams' dog Una, who was a companion on his explorations. Leith publicized the name very soon afterward in September 1904 (Leith, 1906, p. 149-150).

Shaft sinking was begun by the Hobart Iron Co. of Pickands Mather \& Co. in 1905. This shaft, the Sigma mine, was on the South range in the SW1/4 SE $1 / 4$ sec. 8 , T. 45 N., R. 29 W. It was abandoned after a few months in 1906. More drilling and shaft sinking came quickly. By 1909 , about 2,000 drill holes had been completed, and the general limits of the district had been established. The new townsites of Cuyuna, Crosby, and Ironton were established in 1908, 1909, and 1910.

The first shaft of the Kennedy mine reached bedrock in April 1908, and construction of the Cuyuna Range Railroad (later purchased by the Minneapolis, St. Paul \& Sault Ste. Marie RR) to serve the mine and the new towns was begun in 1909. The tracks reached the mine in January 1911, where a stockpile of ore was waiting. The first ore shipped from the district left the mine on April 11 of that year.

Stripping of overburden for open-pit mining was started at the Rowe mine in 1912 and at the Pennington, Armour No. 1, and Thompson mines in 1913.

The demand for manganiferous ores during the war years of 1914-18 exerted a tremendous influence on the Cuyuna district. At the height of this boom 32 mines were operated, most of them in the North range. Activity then diminished until only seven mines were operating in 1921. Mining increased and decreased again following the course of prosperity and depression. From four mines in 1934, the number of operations has increased steadily; the production of the individual properties also increased until 1953, when 3.9 million gross tons of ore was produced. Open-pit mining has replaced underground mining except at the Armour mines, and large trucks and conveyor belts now entirely supplant the railroads in the open pits. About 20 mines are operating, but several of these include more than one of the earlier mines now consolidated for efficiency of operation.

Production of iron ore in the Cuyuna district has decreased since 1953 and may very likely continue at a reduced rate. The marketing of high-grade manganiferous iron ores from the Labrador-Quebec district is expected to continue to be serious competition to the Cuyuna ores.

The prosperity of the villages of Riverton, Trommald, Manganese, Cuyuna, Crosby, and Ironton has risen and fallen regularly with the activity of the mines. All except Crosby and Ironton have been greatly reduced in importance by this fluctuation of income. Crosby has developed some other industries, especially businesses serving summer vacationers, and is no longer so completely dependent on the operation of the mines.

The history of mining in the Cuyuna district includes one great mine disaster. The Milford mine was suddenly flooded by mud and water on February 5, 1924 , and 41 men were killed; only 6 of those working underground escaped (Holbrook, 1939, p. 142-149).

Five companies are now active in the mining operations of the Cuyuna district: Inland Steel Co., M. A. Hanna Co., Pickands Mather \& Co., Rhude and Fryberger, and Zontelli Division of Pittsburgh Pacific Co. Many other persons and companies control significant amounts of property in the North range: George H. Crosby, Adams Bros. Co., W. S. Moore, Snyder Mining Co., Oliver Iron Mining Division of the United States Steel Corp., Ernest·Amberg, Louis Knudson, J. W. Van Evera, E. R. Burns, ClevelandCliffs Iron Co., Gust Carlson, Northern Pacific Railway, the State of Minnesota, and many more. Additional companies and persons have been active in the district in the past.

The land in the Cuyuna district is divided into General Land Office townships and sections. Most sections are subdivided into the smallest standard unit, the sixteenth of a section (40 acres) and partial sections of irregular size are called lots and designated by numbers. Only a few sixteenth sections and lots of mineral land are further subdivided in the district. Property ownership is sometimes separated into "surface rights" and "mineral rights," either or both or which are owned or leased by the iron-mining companies, and there are many complex arrangements of leases and successive subleases. The many lakes in the district further complicate the ownership of mineral rights. Subsurface proprietorship is bounded by planes extending vertically downward from the property lines. 


\section{PREVIOUS GEOLOGIC INVESTIGATIONS}

The first reference to the geology of the district was by Upham (1888, p. 580-611), who briefly described the surficial geology. Owing to the lack of outcrops and deep wells, he knew nothing of the nature of the bedrock in the area that is now the Cuyuna range.

Irving and Van Hise (1892) showed this area on a preliminary geologic map of the Lake Superior region, though they did not discuss it. An area extending from Duluth southwestward to include most of the Cuyuna district and swinging more nearly southward along the Mississippi River to beyond Little Falls was shown as underlain by "Huronian" rocks, the "St. Louis slates."

A similar map accompanied a later publication by Van Hise (1896) in which he discussed (p. 790) contemporaneity of "the greater part of the PenokeeGogebic iron-bearing series of Michigan and Wisconsin; the Chippewa and Baraboo quartzites of Wisconsin; the St. Louis slates of Minnesota; and the newly developed Mesabi range of Minnesota. That most and perhaps all of these areas were once connected, there can be no reasonable doubt."

Later, Leith (1903, p. 202-204) showed a sketch of a possible connection of the iron-bearing rocks in the Mesabi with those in the Penokee-Gogebic district. The suggested belt passed north of Dam Lake, in $\mathrm{T}$. 47 N., R. 25 W., and through the general area of the North range. There is no indication that this map was published in time to have any influence on the search for iron ore in the area.

After the discovery of iron ore in the district, Leith (1907) was the first to publish a lucid geologic report. Many short papers by other persons followed. The section of Monograph 52 (Van Hise and Leith, 1911) on the Cuyuna district is a good review of the knowledge about the district at that time.

The district was first described in detail by Harder and Johnston (1918). They studied the rocks penetrated in drilling and published detailed maps of several of the mines. Many structural features were briefly discussed, and a map of the known belts of iron-formation was the best available for many years afterward. Along with Leith, Zapffe, and other geologists of the time, Harder and Johnston believed that the Cuyuna iron-formation occurred as discontinuous lenses scattered through a slate sequence. Lacking more specific data on correlation with the Mesabi district, Harder and Johnston hesitated to give names to the Cuyuna strata and preferred general terms. Detailed mine maps, descriptions of the individual properties, and complete chemical analyses of ores and wallrocks from Harder and Johnston's bulletin were extensively used in the preparation of this report.

One of the most profuse authors on the Cuyuna district was Carl Zapffe, whose contributions appeared in many short articles rather than in a long report. Undoubtedly Zapffe was as important for his influence on the interpretations of others-for example, Leith, and Harder and Johnston - as he was for his own publications. He was an enthusiastic champion of the district as a source of manganese. In earlier years, he considered the iron ores to occur in discontinuous, sometimes overlapping, lenses of iron-bearing rock (the "Deerwood iron-bearing member") at one general "horizon" in the Virginia slate (Van Hise, and others, 1911, p. 219; Zapffe and Barrows, 1912 , p. 3, 4; Zapffe, 1925a, p. 372). Later, Zapffe argued strongly that the Cuyuna iron-formation was younger than the Animikie rocks of the Mesabi district (1925b) and proposed that the Cuyuna rocks were Upper Huronian, the Mesabi rocks Middle $\mathrm{Hu}$ ronian. Most of his arguments depended on debatable interpretations:

1. The presence of soft, unconsolidated sericitic shale above the Virginia slate at the west end of the Mesabi district, which material Zapffe correlated with the slate abundant in the Cuyuna district.

2. The Cuyuna rocks were probably younger than the St. Louis slate (now called Thomson formation) which had been correlated with the Virginia slate by Van Hise and Leith (1911, p. 611). The Cuyuna rocks were thought to be younger because they seemed to occupy the center of a syncline in which the St. Louis slate and its correlative at Little Falls were on the south and the Virginia slate of the Mesabi district on the north.

3. One drill hole about 30 miles north of Brainerd (probably the hole in the $\mathrm{NW}^{1} / 4$, sec. 5, T. $136 \mathrm{~N}$., R. 29 W., Cass County, near Jenkins) in which, after going through "considerable typical soft, light green, slaty material with steeply inclined schistosity, an undoubted Cuyuna rocks, the drill penetrated flat-lying, banded greyish-black slates, breaking readily and the core parting like poker chips," (Zapffe, 1925b, p. 99). A sample of the dark slaty rock that was probably from the same hole was identified by this writer as quartz-biotite schist, but Zapffe thought "it is exactly like phases of the Mesabi (Virginia) slate formation."

Thiel (1927, p. 788), remarked in reference to the above statement, "Such a structure is difficult to visualize and more difficult to explain if the upper bed is considered the younger."

Zapffe's first point pertaining to the soft lightcolored sedimentary rock overlying the Virginia for- 
mation at the west end of the Mesabi district was developed at great length in a later paper (Zapffe, 1926). The existence of the soft sediments and, in many places, basal conglomerates in the Mesabi, was established beyond a doubt, but no good reason was given for supposing them to be correlatives of the Cuyuna slates. Furthermore, Zapffe himself describes "horizontal beds of soft gray, green, and reddish shaly material, containing conglomerate at the base or above the base" overlying the bedrock in part of the South range (1933. p. 78) which he called post-Keweenawan. These seem a more reasonable correlative of the soft post-Virginia beds of the Mesabi than the Cuyuna slates.

In 1928, Zapffe described the division of the ironbearing rock in the district into a lower and an upper layer. Much of his reasoning probably depended on the interpretation that a large structure was an anticline, even though his own map (Zapffe, 1928, fig. 6) showed it to be synclinal. Had this structure been properly described as a syncline, it is difficult to visualize how Zapffe might have maintained his theory that the ores occurred at two main horizons.

Zapffe later (1930) prepared a general stratigraphic section for the district, dividing the Upper Huronian rocks into a lower Aitkin formation and an upper Crow Wing formation, the latter consisting of an Emily member and a Cuyuna member. The Deerwood iron-bearing member comprised two separated layers of iron-bearing rock enclosed in the Cuyuna member. The iron-formation and ores of the Emily district were believed to be numerous but short lenses of iron-bearing rock.

Zapffe's contribution to the Guidebook of the 16th International Geological Congress, 1933, contained practically the same information as his 1930 publication.

Royce studied the district over a long period of time and knew parts of the district very well, but unfortunately he published only short general papers without detailed maps (Royce, 1938, 1942). In these he proposed a stratigraphic sequence which, except for omission of the upper iron-formation, was very similar to that proposed in this report.

Wolff collected data in the Cuyuna district from 1908 to 1917 , spent most of 1918 in the area, and subsequently visited the district many times. He was particularly familiar with the geology of the Mesabi district, and on the basis of lithologic similarities, he correlated parts of the iron-formation in the Cuyuna district with iron-formation in the Mesabi district (Wolff, 1919) and applied the Mesabi formational names, Pokegama, Biwabik, and Virginia, to the
Cuyuna rocks. Much later the same general ideas, but with considerable revision in details, were presented with a detailed geologic map of the North range and a small part of the South range (Wolff, 1951). The same map appeared later as plate 2, of Bulletin 36 of the Minnesota Geological Survey, of which Wolff and Grout were joint authors. Specific correlations were made by Wolff without much regard to the structure and the changes in sedimentary facies in the district; then faults were inserted where the geology of the adjacent areas seemed incompatible.

Geologic investigations have been conducted over the years by geologists and engineers of many of the mining companies in the district. Detailed maps and the interpretations and deductions resulting from some of these unreported studies are of very high quality and surpass much of the material that has been published. The author was privileged to see some of these maps and to discuss the geology at great length with the mining company personnel.

\section{PRESENT INVESTIGATION}

The fieldwork of this investigation was begun in 1951 and completed in 1954, except for a month in 1955 and a few days in 1956. C. E. Dutton worked in the field with the writer for 2 months during the summer of 1951 and gave the benefit of his broad experience at the beginning of the project. He also remained project adviser until this report was completed.

Fieldwork consisted of detailed mapping of all accessible mines. Up-to-date company mine maps were used in the field for plotting geologic information. The maps of open pits, which were at a scale of 1 inch equals 50 feet, showed details of benches and banks, which made it possible to locate any point in a mine quickly and accurately to within a few feet. Geologic mapping in the Armour underground mines was likewise done on prints of the company maps at a scale of 1 inch equals 30 feet. Maps of the whole North range were prepared on a base provided by the M. A. Hanna Co.

Much of the work necessary for the preparation of detailed maps was the examination and classification of many thousands of samples consisting of drill cores and cuttings from about 2,000 exploratory holes. These included samples from holes drilled from 1905 to 1956. In addition, the company logs of 8,000 drill holes were scanned, and those yielding pertinent information were used in the development of the geologic details. Samples were collected in the mines for 38 complete chemical analyses of representative ores and related rocks, for 120 thin sections, and for many mineralogic 
determinations, partial chemical analyses, heavy mineral separations, and semiquantitative spectrographic analyses.

A group of preliminary geologic maps of the accessible mines was prepared and placed on open file in 1952 (Schmidt and Dutton, 1952). Detailed geologic maps of the entire North range were published in 1957, 1958, and 1959 (Schmidt and Dutton, 1957; Schmidt, 1958a, 1959).

Much geophysical work has been done by the Geological Survey in the area by using a variety of geophysical methods closely coordinated with the results of the geological study provided by the writer. A later report will describe the geophysical investigation.

\section{ACKNOWLEDGMENTS}

The present investigation could hardly have been carried to completion without the generous help of a host of persons. So many assisted that it would be impracticable to name them all, though it would please the writer to do so.

Several men are cited for their outstanding contributions to the project. C. E. Dutton spent much time and effort helping with the field studies during the early months, reviewing the manuscripts, and advising on the conduct of the project throughout. J. O. Owens, of the M. A. Hanna Co., gave generously of his time and knowledge, provided a tremendous amount of geologic data, assistance in sample logging, and encouragement and valuable criticism of geologic theories. George Chamberlain and Neal Walker, of Pickands Mather \& Co., likewise gave considerable time in the search for obscure records and provided helpful advice. Louis Knudson, of the Oliver Iron Mining Division, United States Steel Corp., was a ready source of information on exploratory drilling methods, geophysical methods, and on geographic and historical details about the district.

Other persons who were especially helpful are T. A. Anderson, Cecil Carlton, D. W. Carlton, F. M. Chase, Rodger Chapman, S. E. Erickson, Jack Everett, Nelo Hill, Dudley Kean, Lemoyne Olson, Clyde Pearce, Richard Strong, Michael Walle, and Paul Zimmer.

Drill records, access to sample collections, and mine maps were provided by all the operating mining companies and several companies and individuals controlling properties in the district. These included Adams Brothers Co., E. R. Burns, Cleveland-Cliffs Iron Co., M. A. Hanna Co., Inland Steel Co., W. S. Moore Co., Oliver Iron Mining Division of United States Steel Corp., Pickands Mather \& Co., Rhude and Fryberger, Snyder Mining Co., and Zontelli Bros., Inc.

\section{GENERAL GEOLOGY}

REGIONAL SETTING

The strata of the Cuyuna district are a tightly folded sequence of slightly metamorphosed Precambrian rocks consisting of argillite, slate, phyllite, and iron-formations, and lesser amounts of coarser clastic rocks and volcanic tuff and flows. The bedrock is covered by Pleistocene glacial drift to depths of 15 to more than 200 feet throughout the area studied, except where exposed by mining operations. Only beyond the southwest and northeast limits of the mapped area have a few scattered outcrops been found, and the relation of these to the Cuyuna rocks is not adequately known.

The trend of the Cuyuna folds is about N. $65^{\circ} \mathrm{E}$. and parallels the axis of the Lake Superior synclinorium. Previous writers (Harder and Johnston, 1918 , p. 112; Zapffe, 1928, p. 625) have considered that the Cuyuna district is near, or somewhat north of, the axis of the geosyncline, which was thought to explain the intensity of the folding and perhaps also the degree of metamorphism.

There is very little information on the relation of the sequence of metasedimentary rocks in the Cuyuna district to the other Precambrian rocks of Minnesota. The geology has been determined in detail, however, for areas of extensive exploration in the Mesabi district, in part of the Emily district, in the Cuyuna North range, and in small parts of the Cuyuna South range. The general geology of the area southeast of the Cuyuna district has been described in a report on the Thomson formation by Schwartz (1942) and one on the intrusive igneous rocks by Woyski (1949). In other directions from the Cuyuna district and in the areas east and west of the Emily district, outcrops and drill-hole data are exceedingly sparse, and the relation of the various outcrops and the drill-hole samples to each other are as unknown as their relation to the Cuyuna rocks.

The areas of various rocks adjacent to the Cuyuna district are shown on plate 1 , on which the available geologic data have been compiled from many sources with adaptations by the writer, and the sources of various data are shown on the accompanying index map. The rocks occurring near the Cuyuna district are discussed in the following paragraphs.

Only widely scattered drilling has been done on the north side of the Mississippi River in the 8-mile gap that separates the Cuyuna and Emily districts. Drilling has been insufficient to establish or disprove a direct connection between the iron-formation of the two areas, but the writer believes that the connection 
probably exists. White (1954) has described similarities between the rocks of the Emily and Mesabi districts, which are generally believed to be correlative, but between which no actual connections have been made.

Very little is known of the rocks west of the Emily district and northwest of the Cuyuna North range. Grout and Wolff (1955, pl. 1) show scattered small areas of dolomite, greenstone schist, and granite in the northwestern part of Crow Wing County and in the adjacent part of Cass County. They assumed these to be pre-Animikie, but no specific relationships are known.

Thirteen holes were drilled in secs. 23 and $33, \mathrm{~T}$. 134 N., R. 28 W., and in sec. 1, T. 133 N., R. 29 W., north and west of Brainerd in 1909 . The holes penetrated light-gray and light-green argillite and siltstone and chloritized gabbroic igneous rock. Some of the siltstone contained small magnetite or martite octahedra and was similar to the magnetic siltstones in the Mahnomen formation associated with areas of magnetic anomaly in the North range; the writer assumes, therefore, that the sedimentary rocks are part of the Mahnomen formation (pl. 1), the lowest of the three sedimentary formations in the North range.

Various granites crop out $20^{\circ}$ miles west of Brainerd near Staples (Harder and Johnston, 1918, p. 30-31) and farther south in Todd County near Browerville (p. 31). Gabbro and anorthosite crop out near Philbrook in Todd County rather close to places where iron-formation has been located by exploratory drilling (pl. 1) (Grout and Wolff, 1955, p. 16). The ironformation near Philbrook is more highly metamorphosed than most iron-formation of the Cuyuna district and is some distance from the nearest South range iron-formation at Randall, and possible correlation with the Cuyuna district should be considered only tentative at this time.

Dark gray-green chlorite schist is exposed in outcrops at the railroad station in Randall and for about half a mile south. These outcrops are about 1.5 miles southeast of iron-formation of the South range which has been traced by drilling for a short distance near Randall (pl. 1). The schist at Randall was considered by Harder and Johnston (1918, p. 58-59) to be similar to schist in the operating mines near Brainerd and Crosby. It is probably more highly metamorphosed than the North range schists, but the ironformation in the Gorman mine near Randall is also more highly metamorphosed than North range rocks.

Outcrops of the Thomson formation, locally a phyllite and a staurolite-biotite schist, and of hornblende granodiorite and hornblende gabbro have been re- ported near Little Falls (Woyski, 1949, p. 1010, 1013, 1015). (See pl. 1.)

Granitic rocks were described from several places south of Mille Lacs Lake (Woyski, 1949, pl. 1; Henderson and Meuschke, 1953a). McGrath gneiss crops out near McGrath, in sec. 6, T. 43 N., R. 23 W., and near Denham in T. 45 N., R. 21 W. Granite or gneiss was drilled in the well at Malmo, T. 45 N., R. $25 \mathrm{~W}$. Iron-formation, slate, and a large pyrite-pyrrhotite body were drilled in the southwestern part of T. 46 N., R. 25 W., near Glen (Harder and Johnston, 1918, p. 128; Schwartz, 1951b; Henderson and Meuschke, 1953b; Grout and Wolff, 1955, p. 86-87; Han, 1958, p. 24). Quartzite forms several low outcrops northwest of Dam Lake in sec. 34, T. 47 N., R. 25 W., and drilling north of the outcrops penetrated iron-formation underlain by a schistose quartzite (Adams, 1910, p. 734) ; presumably these are part of the Cuyuna sequence. South of Dam Lake, in secs. 9 and 10, T. 46 N., R. 25 W., diorite and diabase crop out in several places.

In sec. 1, T. 47 N., R. $25 \mathrm{~W}$., and sec. 6, T. 47 N., R. $24 \mathrm{~W}$., near Kimberly, iron-formation and slate were drilled in two explorations totaling 32 holes.

Schwartz (1942) has described the Thomson formation occurring in Carlton County, many miles east of the last Cuyuna-type rocks. He considers it to be pre-Animikie and relates the southwestward-increasing metamorphic grade to intrusion of Algoman McGrath gneiss. The Thomson formation is also slightly metamorphosed along the contacts of diabase dikes and sills.

Northeast of the Cuyuna district, especially in northern Aitkin County, outcrops are entirely lacking, the drift cover is 75 to more than 300 feet thick, and drilling is very sparse. The underlying rocks are generally slate and what was called schist, in places black or "graphitic," locally overlain by soft Cretaceous shales (Henderson and Meuschke, 1953c). The age of the slates has not been established, but Wolff thinks that they are equivalent to the Virginia slates (Grout and Wolff, 1955, p. 83).

Outcrops have been reported on the west side of Waukenabo Lake, in T. 49 N., R. 26 W., and on the north side of Esquagamah Lake (pl. 1), probably in the same township (Himrod, 1940, p. 4). The writer has not confirmed this. The drift cover penetrated by drill holes in the same township ranges from 173 to 242 feet.

The U.S. Bureau of Mines drilled 7 holes in sec. 23, T. 48 N., R. 27 W., Aitkin County, in manganiferous argillite (Grosh and others, 1953). The cores are faintly foliated gray and red-brown sericitic argil- 
lite. None of the material is considered to be ironformation by the writer. The argillite is not greatly unlike parts of the Mahnomen formation in appearance, though its iron content is more nearly like that in the Rabbit Lake formation.

By tentatively accepting the correlation of the Cuyuna rocks with those of the Mesabi district, as suggested by Cheney (1915), Wolff (1919), and others, one may deduce some general relationships by analogy with that district. The sequence of three formations in the Cuyuna district may be assumed to rest unconformably on a surface of Algoman granite and various other older rocks. These older rocks probably include most or all of the granitic rocks mentioned above occurring near the Cuyuna distr ct, and the Thomson formation occurring to the east and to the south. Some of the gabbroic and dioritic intrusives outside the district resemble rocks intrusive into the Cuyuna rocks and are probably younger than the Cuyuna sequence.

\section{CUYUNA DISTRICT}

In a simple interpretation the sequence of metamorphosed argillaceous rocks and iron-formations in the Cuyuna district is probably of Animikie age and occupies a much folded northeast-trending synclinorium (pl. 1) bounded by older rocks, except at the northeast end where the structure apparently widens. The sequence probably connects northward with the Animikie rocks of the Emily and Mesabi districts and disappears eastward under a thick cover of Pleistocene and perhaps Cretaceous materials.

The base and the top of the threefold sequence of sedimentary rocks in the synclinorium have not been seen. The lower unit is the Mahnomen formation, which consists of at least 2,000 feet of light-colored argillite or slate and quartz siltstone and includes local quartzite lenses and layers near the top. The middle unit is the Trommald formation, which is almost wholly an iron-rich chemical sediment known as iron-formation and contains only local thin layers of clastic sediments; an iron-oxide-rich thick-bedded facies of this formation is confined to part of the North range and overlaps an iron silicate- and iron carbonate-rich thin-bedded facies which occurs in part of the North range and probably all of the South range. The Trommald formation generally ranges in thickness from 45 to more than 500 feet. The highest unit is the Rabbit Lake formation which is argillite and slate, partly carbonaceous and ferruginous; it has lenses of lean cherty iron-formation distributed throughout and local basaltic flows or sills and prob- ably tuffs near the base. The Rabbit Lake formation is at least 2,000 feet thick.

The sedimentary rocks in this synclinorium have been tightly folded, probably by forces acting from the southeast, and subjected to metamorphism which increased gradually toward the south or southeast. In the North range the strata were intruded by diorite or gabbro dikes during or after folding. These intrusive rocks were metamorphosed with the sedimentary rocks.

The rocks of the Cuyuna district and older rocks were eroded to a surface of low relief. Van Hise and Leith (1911, p. 215) described an amygdaloidal silicic extrusive occurring locally in the South range in horizontal layers 15 to 25 feet thick resting on the eroded surface of the steeply dipping iron-formation and slate in sec. 2, T. 44 N., R. 31 W., sec. 6, T. 44 N., R. 30 W., and sec. 7, T. 45 N., R. 29 W. (pl. 1). They believed this extrusive to be Keweenawan.

Cretaceous fossils have been identified in soft shales overlying folded slates in northern Aitkin County (Grout and Wolff, 1955, p. 83). No Cretaceous sediments have been identified in the Cuyuna district. Horizontally stratified conglomerates on the Precambrian surface are probably all Pleistocene, though they generally resemble some Cretaceous rocks of the $\mathrm{Me}$ sabi district.

The iron ores have developed within the 'Trommald formation, except for a few small ore bodies within iron-formation lenses in the Rabbit Lake formation. The ores are residual, having formed by leaching of the original minerals of the iron-formation: quartz and one or more iron oxides, silicates, or carbonates. The ores form by the removal of carbon dioxide, silica, and magnesia; the removal results in porous and vuggy ore. The ores were probably formed in two stages-the first involving ground waters that possibly were partly hydrothermal and affecting the iron-formation to great depths, the second being a shallower alteration related to ordinary surface weathering.

The time of the formation of the Cuyuna ores has not been established. It is probable that the land surface has remained relatively stable since Precambrian time. The flat-lying Keweenawan flows, if the assigned age is correct, suggest that there has been very little subsequent erosion of the pre-Keweenawan rocks. The ores may have formed at any time since the formation of the general plain, or they may have been forming during most of the intervening time.

The kind and distribution of the ores differ considerably according to the areas within the district and according to the facies of the Trommald formation 
that is present. The most important ore bodies have formed along the southeast edge of the North range in the thin-bedded facies. Other important deposits have formed in the thick-bedded facies in the North range. A smaller number of minable ore bodies occur in the thin-bedded facies on the northwest side of the North range, in the South range, and in the iron-formation lenses of the Rabbit Lake formation.

\section{SEDIMENTARY ROCKS}

Precambrian sedimentary rocks comprising three formations make up most of the bedrock of the Cuyuna district. A stratigraphic sequence of perhaps 4,500 feet is suggested, and new names are proposed for the formations. The distribution of these-the Mahnomen, Trommald, and Rabbit Lake formations-is shown on plate 2. The relation to other Precambrian rocks of Minnesota cannot be definitely established at this time, although it is probable that the three formations correlate with the Animikie group of the Mesabi district. No contact of Mahnomen formation and an older rock has been found, and no sedimentary rock younger than the Rabbit Lake formation occurs in the North range, except the glacial drift that everywhere covered the bedrock on the North range before mining began.

The stratigraphic sequence proposed in this report differs from the sequences described by Van Hise and Leith (1911), Zapffe (1930), and Wolff $(1919,1951)$ in many ways, and the areal distribution of each unit is generally unlike that of any unit formerly described. This is most noticeable for the units mapped by Wolff. The three sedimentary formations described here are considered to be the probable correlatives of the three Mesabi district formations, but the correlation is far from definitely proved. The Cuyuna formations resemble their Mesabi counterparts in only the most general ways, and because definite evidence regarding correlation is lacking, the names of the Mesabi formations were rejected for the Cuyuna strata. Other unit names formerly used were rejected because they were vaguely defined and because the map areas assigned to each were unlike any of the units mapped in this study; these old stratigraphic names would add too much confusion to the literature on the district.

In this report the new names-Mahnomen, Trommald, and Rabbit Lake formations-are proposed for the three sedimentary units. Type sections of the new formations were impractical, for no natural outcrops occur in the area studied. The entire Trommald formation is exposed in several open-pit mines, but such places are exposed only when the mine is kept dewatered. Only the very top of the Mahnomen formation and the base of the Rabbit Lake formation are exposed in mines, and most information regarding them comes from drill-hole samples. Type areas were chosen to include as many lithologic types as possible, as well as good mine exposures or many drill samples.

Determining the stratigraphic sequence in the Cuyuna district has been complicated by relatively abrupt facies changes in all formations, which suggests that currents in the basin of deposition were shifting and perhaps the bottom gradients were steeper than those commonly associated with the deposition of iron-formation in other Lake Superior districts. The writer believes that rocks analogous to each of the lithologic types found in the Cuyuna are common in other Lake Superior districts, but the great variety of lithologic types is not found in such a small area elsewhere. The solution of the stratigraphic sequence has been further complicated by tight folding that has resulted in the overturning of beds in many places. In studying and mapping the geology of the Cuyuna North range, it was necessary to resolve the problems of structure and stratigraphy simultaneously, as neither could be deciphered without the other. Extensive alteration that may be generally likened to saprolitization, regardless of the source ascribed to the leaching solutions, has changed the appearance of the rocks to various degrees and has complicated correlation. Metamorphism in the North range is low grade (chlorite and biotite zones) and uniform, and has caused only local correlation problems.

Structural information to supplement lithologic observations was obtainable only from mine openings and drill cores because there are no outcrops. Most of the rock exposed in mining is iron ore, and the cost of removing overburden generally restricts the size of exposures of less altered iron-formation and especially wallrocks. The wallrock exposed in mining is mostly less than 100 feet stratigraphically above or below the iron-formation. Likewise, most exploratory drill holes are in or close to iron-formation, and the number of drill holes in wallrocks decreases sharply as the distance from the iron-formation increases. Logs of about 8,000 drill holes in the North range were assembled during this study, more than 6,000 of which were furnished by the U.S. Bureau of Mines. It was found that most existent logs of drill holes are of little use, for most wallrocks and even many parts of the iron-formations have been called schist in the old drill $\operatorname{logs}$, therefore, the original samples were reclassified if possible. Samples were examined from 
about 2,000 drill holes, including many drilled during the early years of exploration as well as many of those drilled during the period of the study. The writer was fortunate that many samples from old drillings are still available.

It was found that almost all the cores of the Cuyuna North range occur in one well-defined stratigraphic unit, designated in the field as the main iron-formation, for which the name Trommald formation is here proposed. Most of the rocks in the mines are part of this formation, and more drill holes penetrate it than any other; it is therefore generally well known in most of the North range. The top and bottom of the Trommald formation are the only very clearly defined and widespread stratigraphic horizons found during this study, and they have been used throughout for stratigraphic measurements.

Interpretation of the stratigraphy of the iron-formation presented here differs considerably from that of some previous workers. Many of the structures mapped in detail during the fieldwork has been known in a general way, and the lithologic characteristics of the thick- and thin-bedded facies of the Trommald formation were recognized many years ago. Interpretations of the relation of the facies of the Trommald formation and the several lenses of upper ironformation in the Rabbit Lake formation have been exceedingly divergent, and these have considerably affected stratigraphic correlation and large-scale structural interpretation within the North range. The stratigraphic relations of the Trommald formation, because that formation has been most thoroughly explored in drilling and the most exposed in mining, is the heart of the controversy regarding Cuyuna stratigraphy.

Very little was known of the geology of the Cuyuna district until exploration for iron ores was begun; diamond drilling first brought samples of concealed bedrock to the surface for observation in 1903 (Himrod, 1940), about 1 year before merchantable ore was discovered.

In 1907 Leith published the first description of a stratigraphic succession, probably based on materials derived from both North and South ranges. Leith's stratigraphic succession, strikingly similar to the succession proposed in this report, was as follows, from bottom to top (Leith, 1907, p. 146) :

Quartzite and its altered equivalents, quartzese, micaceous and hornblende schists.

Iron formation, consisting principally of iron carbonate where unaltered, but largely altered to amphibole-magnetite rock, ferruginous slates, and iron ore. The ores thus far found are soft, reddish, slightly hydrated hematite, reddish slaty hematite, and hard, blue, banded, siliceous magnetite and hematite.

Chloritic and carbonaceous slate, interbedded in its lower part with iron formation.

Intrusive granite and diorite, principally the latter.

Cretaceous sediments.

Glacial drift, 80 to $\mathbf{3 5 0}$ feet.

A similar sequence was inferred by Cheney (1915), and the Cuyuna-Mesabi equivalence was argued by him. The order of deposition described by him was generally quartzite and slate, succeeded by iron-formation, which was succeeded by Virginia slate.

Royce did not favor correlation with the Mesabi, but described a similar sequence (1938, p. 51-53), and excerpts are quoted here:

Detailed geological mapping of the district has shown that most, if not all, of these bands of iron formation lie in a single horizon, repeated many times by folding.

*** The hangingwall slate overlying the formation is a gray to black slate with graywacke, or coarse-grained, bands. The footwall slate is a soft, impure, shaly quartzite near the ore and grades downward into gray slate.

Harder (1910) described a generalized succession of amphibole-magnetite rock followed by ore and then green slate. "Amphibole-magnetite rock" would actually have been an unoxidized part of the iron-formation.

Van Hise and Leith (1911), perhaps influenced by the ideas of Zapffe, placed the Cuyuna district ironformations in the Upper Huronian as the lenticular Deerwood iron-bearing member within the Virginia slate. Specific successions of rocks were not discussed.

Francis S. Adams (1911a, p. 60) also considered the Cuyuna iron-formation to be discontinuous lenses distributed through the light-gray, light-green, and black slates of Upper Huronian age. He suggested that the quartzite at Dam Lake, T. 47 N., R. 25 W. (pl. 1), and quartzite found in sec. 24 , T. 47 N., R. 29 W., were at the base of the slate-iron-formation sequence and were equivalent to the Pokegama quartzite of the Mesabi district (Adams, 1910, p. 734).

Zapffe and Barrows (1912) wrote that the ironbearing rocks "seem to occupy a more or less definite horizon in the Upper Huronian group, and are known as the Deerwood member of the Virginia slate formation." Interbedded basic tuffs and flows in the Virginia formation were emphasized.

Zapffe $(1928,1930)$ presented the idea that the ironformation was in two separated but distinct layers enclosed in the Cuyuna slate and schist member of the Crow Wing formation.

Wolff $(1919,1951)$ and Grout and Wolff (1955) regarded the Cuyuna iron-formation as a very complicated sequence. Beds that differ in appearance in the various mines were assigned different stratigraphic 
positions that correspond to the positions of similar appearing beds in the Mesabi district. A stratigraphic sequence of iron-formation, called the Biwabik formation as in the Mesabi district, was expanded to a thickness of 2,575 to 3,465 feet, and areas of bedrock associated with the Biwabik were shown as Pokegama formation and Virginia formation. The iron-formation of the South range was included as an intercalated layer in the Virginia formation.

\section{MAHNOMEN FORMATION}

The oldest formation in the Cuyuna stratigraphic sequence, which is here named the Mahnomen formation of middle Precambrian age, is a sequence of argillite and siltstone and a small amount of quartzite. The name is taken from the Mahnomen group of mines which also constitutes the general type area. The more argillaceous parts are slaty in many places. Minor amounts of shale, sandstone, phyllite, schist, graywacke, and limestone were observed. Quartzite is locally abundant at the top of the unit near the contact with the overlying formation. In a very general way, quartzite is more abundant in the western part of the North range and is entirely absent in some places in the eastern part of the range. Shale is present in samples from several drill holes northwest of the Sagamore; sandstone occurs locally instead of quartzite, perhaps as a result of re-solution of the quartzite cement; phyllites and schists occur in many small areas, probably as a result of shearing during folding. Graywacke was seen at only one place, in the NW1/4NE1/4 sec. 35, T. 47 N., R. 29 W.; limestone is rather common in core from one unusually deep drill hole on the Northland property in the SW1/4 NW $1 / 4$ sec. 20 , T. 47 N., R. 28 W. (pl. 2).

Argillaceous parts of the Mahnomen formation are dominantly mixtures of sericite and fine-grained quartz. Lesser amounts of biotite and chlorite occur mixed with fine muscovite. The fine quartz is intermixed with the mica, but in many samples abundant quartz in alternating thin layers gives the rock a conspicuously laminated appearance. The micas tend to parallel the axial planes of folds, which, because of the close folding prevalent in the district, are nearly parallel to the bedding in most specimens. Minor amounts of tourmaline, leucoxene, pyrite, hematite, carbon, and magnetite were observed.

The siltstones are fine-grained quartz-rich rocks, containing considerable muscovite, biotite, or chlorite. Plagioclase grains are sparingly present in most specimens and are common in a few. Magnetite or martite, generally in half a millimeter octahedra, is present in many areas; and the magnetite, though sparse, has been responsible for weak magnetic anomalies in sev- eral areas. Some of the areas were drilled because the anomalies were thought to result from iron-formation. The siltstones are soft to hard and massive to faintly bedded. Micaceous material and quartz overgrowths on the quartz grains are the main cements.

The quartzite contains various amounts of argillaceous material. Many specimens are composed of well-rounded and well-sorted quartz grains cemented by quartz and minor amounts of mica-mostly sericite-and chlorite, calcite, and iron oxides. In some places, the quartz cement has formed by grain enlargement; in others, the cement is a fine-grained mosaic of quartz. There is a complete gradation from quartz-cemented quartzites through argillaceous quartzites to sandy argillites. The quartzite beds are lenticular. At several places in the district the quartzite contains clay pebbles or flakes as much as 2 inches long and a quarter of an inch thick.

Heavy-mineral separations from siltstone and quartzite in the Mahnomen formation contain abundant needles of authigenic tourmaline and a few very well rounded hyacinth zircons. Chemical analyses of samples from the Mahnomen formation are shown in tables 1 and 2. The analyses of the two samples in table 1 are probably typical of the argillite-slate facies of the Mahnomen formation. In the most argillaceous parts of the formation the alumina may exceed 20 percent; in the siltstone and quartzite, alumina may be as low as 5 percent of the sample.

TABLE 1.-Chemical analyses of two samples from the Mahnomen formation

[S. M. Berthold, U.S. Geological Survey, analyst]

\begin{tabular}{|c|c|c|}
\hline & 157 & 173 \\
\hline 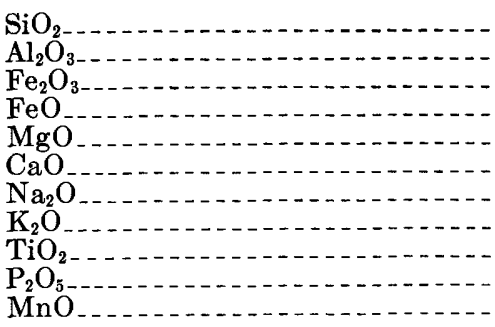 & $\begin{array}{r}\text { 66. } 0 \\
16.6 \\
3.0 \\
2.3 \\
1.5 \\
.27 \\
.12 \\
5.5 \\
.55 \\
.03 \\
.06\end{array}$ & $\begin{aligned} 69.7 \\
15.5 \\
4.5 \\
.73 \\
1.1 \\
.27 \\
.11 \\
5.1 \\
.48 \\
.02 \\
.00\end{aligned}$ \\
\hline Total & 95.9 & 97.5 \\
\hline
\end{tabular}

157. Gray sericitic slate. Grab sample from Mahnomen mine; coordinates: $320 \mathrm{SE}$.

1,400 NE.; alt, 1,023 ft. Collected June 1952 . Lab. No. 52-1422CW.
173. Sericitic slate. Grab sample from Maroco mine; coordinates: $780 \mathrm{~S}$., 3,650 E., alt, 1,153 ft. Collected June 1952. Lab. No. 52-1427CW.

In a deep angle hole on the Northland property, sec. 20 , T. 47 N., R. 28 W. (pl. 2) drilled by the University of Minnesota, the Mahnomen formation was cored from the upper contact to about 460 feet stratigraphically below the contact. From 200 feet below the contact to the bottom of the hole, thin carbonate and siliceous carbonate lenses were found; and below 
330 feet from the contact, there were several hard beds of light-cream and tan limestone as much as 18 inches thick.

The bottom of the Mahnomen formation has not been found in the North range, and owing to the lack of exposures and recognizable stratigraphic horizons within the formation, the total thickness explored can only be roughly estimated as at least 2,000 feet. The upper contact of the formation is conformable and sharp. Drill samples from the $\mathrm{N} 1 / 2$ sec. 22, $\mathrm{T}$. 47 N., R. 29 W. (pl. 2), suggest, however, a transition from quartzite in the Mahnomen formation through ferruginous quartzite into sandy iron-formation in the Trommald formation.

The Mahnomen formation has been commonly referred to in the district as the "footwall," the name indicating a stratigraphic position below the main iron-formation rather than a relative structural relationship.

There are excellent exposures of the Mahnomen formation in the Mahnomen Nos. 1 and 3 mines, containing the lithologic types most commonly found in this formation. Though these are the largest exposures in the district, only about 100 feet of the top of the formation is visible.

\section{MAFNOMEN NO. 1 MTNE}

The Mahnomen formation is exposed in a large tightly folded anticline on the northwest side of the Mahnomen No. 1 pit (pl. 3). The intensity of folding in the incompetent argillaceous material has caused the development of intricate drag folding and slaty cleavage throughout much of the exposure. The most abundant rock is a laminated gray sericitic slate. A layer of quartzite 6 feet thick was found 60 feet from the south edge of the formation in the west wall of the mine. Near this same place, about 20 feet from the upper contact, the slate contains sand grains and small chert nodules. Finely interlaminated siltstone and layers of light-green to dark-gray micaceous phyllite were well exposed in a small area 160 feet northwest of the southeast corner of the $\mathrm{SW} 1 / 4 \mathrm{SE}^{1} / 4$ sec. 3 . Some of the dark-gray layers contain laminae of pyrite on parting surfaces. This exposure contains very little of the red-brown and brown coloration characteristic of the formation in other parts of the district. On the southeast side of the mine, the Mahnomen formation is again exposed in a tight slightly overturned plunging anticline. Here it is gray and red-brown slate and has generally well-developed cleavage.

\section{MAHNOMEN NO. 3 MINE}

A large exposure on the northwest side of the Mahnomen No. 3 mine (pl. 3) is a gray sericite slate; the exposure also includes many beds of gray quartzite and sandy slate. The contact with the Trommald formation is exposed in the northwest bank of the mine and parallels the length of the mine. Locally, especially near the contact, the slate is brown or red brown. About one-quarter or one-third of the Mahnomen formation exposed is quartzite; the rest is sandy slate and sericitic slate. The quartzite and sandy slate are in beds from less than an inch to several feet in thickness. Many beds of quartzite contain clay flakes or thin flat clay pebbles.

\section{OTHER EXPOSURES AND DRILLHOLE SECTIONS OF THE MAHNOMEN FORMATION}

Other excellent exposures of the Mahnomen formation in the general area of the Mahnomen mines were seen in the Louise, Hillcrest Extension, and Alstead mines (pl. 3).

The Mahnomen formation is exposed in several places along the northwest side of the Maroco mine (pl. 3) and of the Section Six mine, sec. 6, T. 46 N., R. $29 \mathrm{~W}$. (pl. 2). Quartzite is the dominant rock in both mines, but gray and brown slate is also present. Clay pebbles were common near the east end of the Maroco mine. The thickness of the dominantly quartzitic beds in the Maroco-Section Six mine area is not known; it may be as little as 100 feet or as much as 1,000 feet.

There are several good exposures of the Mahnomen formation in the Sagamore mine (pl. 4). Gray and brown slate and local lenses of greenish-gray and brown quartzite form a prominent exposure on the northwest bank of the No. 2 mine. Steeply plunging folds combined with minor shearing near the contact have complicated the geology in this exposure. The quartzite is about 100 feet thick, and drill samples show that it is a lens extending about 1,000 feet southwest. No quartzite was found in drill holes northeast of the exposure in the mine.

There were several small exposures of the Mahnomen formation at the northeast end of the Sagamore No. 1 mine. The exposures were of soft gray and brown siltstone and argillite.

Many drill holes penetrate the Mahnomen formation north and east of the Sagamore mine, and many more holes in sec. 18, T. 46 N., R. 29 W., to the north, provide a very complete record of the nature of the bedrock in this area (pl. 4). Quartzite is found at the Rowe mine in sec. 18 for perhaps 100 feet below the upper contact; the rest of the area between the Sagamore and Rowe mines is underlain by gray, buff, and red-brown argillite and slate; sandy argillite; and gray or brown to white quartz siltstone. Drilling has 
also penetrated siltstone, argillite, shale, and slate of this formation just east of the Sagamore mine as far southwest as the center of the NW1/4 SE $1 / 4$ sec. 19.

In the southwest end of the Sagamore No. 2 mine, soft red-brown and gray laminated clay and silt resembling and presumed to be the Mahnomen formation overlie the Trommald formation structurally and were probably thrust faulted into place (pl. 3, section $\left.D-D^{\prime}\right)$. Farther south in the $\mathrm{SW} 1 / 4 \mathrm{SW} 1 / 4$ sec. 19 , several drill holes penetrated light-gray and buff argillite and gray siltstone interpreted to be Mahnomen formation.

A remarkable group of drill holes in the Mahnomen formation was completed in sec. 26, T. 46 N., R. 30 $\mathrm{W}$., in 1913 . The 34 holes extended in a somewhat irregular north-trending line for 4,200 feet from the $\mathrm{SW}_{1 / 4} \mathrm{SE} 1 / 4$ to the NE $1 / 4 \mathrm{NW}^{1} / 4$ of the section (pl. 2). The samples of bedrock are gray and lesser amounts of red-brown sericitic argillite and also silty argillite, siltstone, and sandstone south of the center of the section. One sample was described as gray sericitic slate. One can only guess at the stratigraphic thickness represented in this group of drill holes; it is perhaps as much as 2,000 or 3,000 feet, and this thickness does not start at the top of the formation. However, the lack of definite structural information prevents the use of these drill samples to increase the known thickness of the Mahnomen formation.

Drilling northwest and west of Little Rabbit Lake in sec. 18, T. 46 N., R. 29 W., and sec. 13, T. 46 N., R. $30 \mathrm{~W}$. (pl. 4), revealed a thickness of perhaps 400 feet in which quartzite is interbedded with slate at the top of the Mahnomen formation.

The Mahnomen formation was extensively drilled along the west side of sec. 16, T. 46 N., R. 29 W. (pl. 3), in 1911 and in 1948-49, and the samples from 17 drill holes from the Martin mine southward for 3,000 feet were examined. The bedrock here is argillite, especially sericitic argillite, and slate, which is silty in some samples near the top of the unit at the Martin mine. One hole beneath the northeast end of the Blackhoof Lake, about 200 feet from the contact with the Trommald formation, was in siltstone. Southeast of Blackhoof Lake the Mahnomen formation is cut off by a long mass of diorite that is probably intrusive. The diorite contact is 3,000

TABLE 2.-Analyses of minor

The concentrations of the elements as determined by semiquantitative spectrographic analysis are bracketed into groups each of approximately one-third of an order of of semiquantitative results with those obtained by quantitative methods, either chemical or spectrographic,

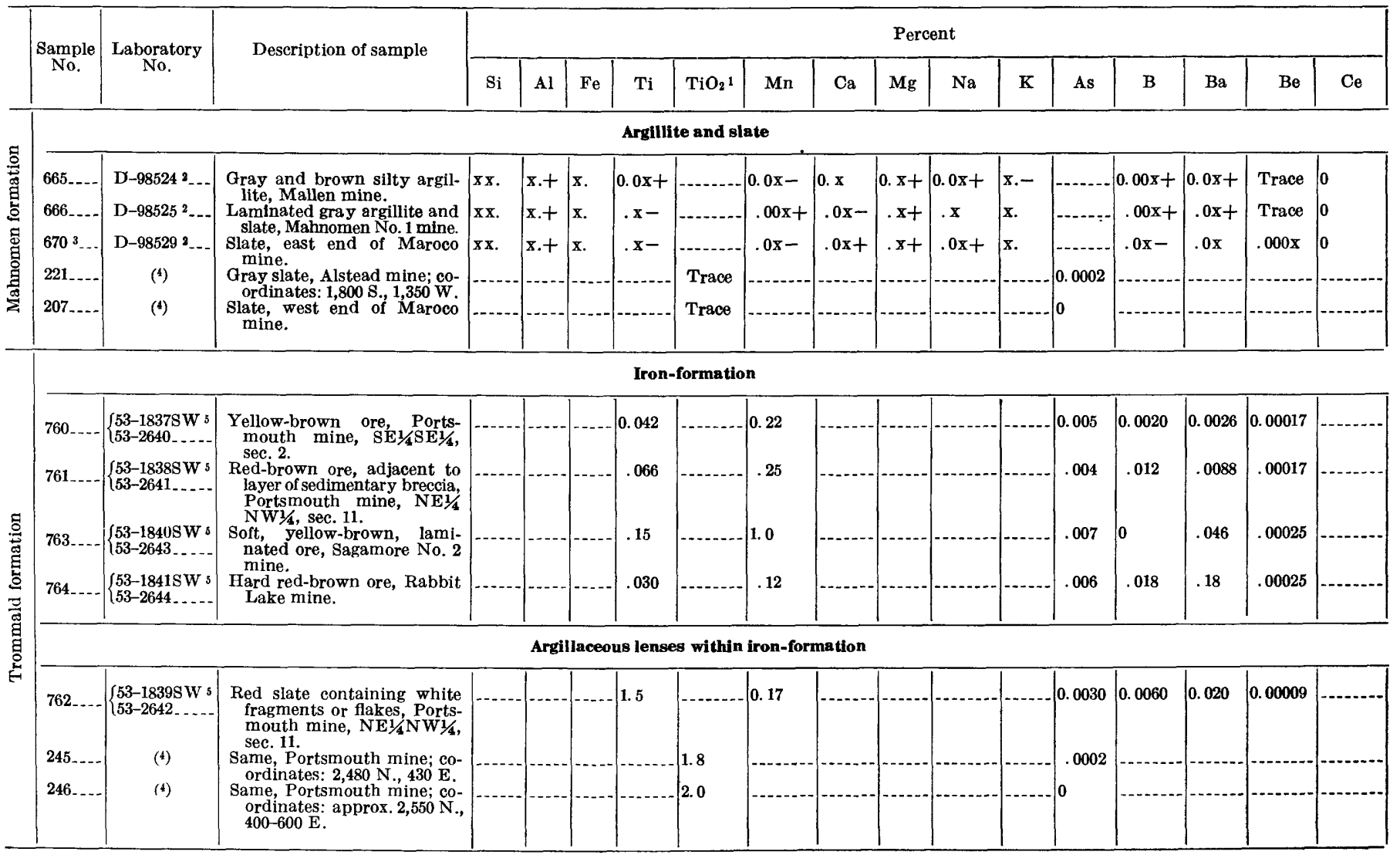

See footnotes at end of table. 
feet southeast of the Trommald formation contact at the Martin mine; the contacts diverge slightly to the southwest and converge to the northeast. The bedrock here is on the southeast limb of a major synclinal fold, probably considerably complicated by drag folding. It cannot be assumed that the 3,000 feet of bedrock outcrop represents 3,000 feet of stratigraphic section, although the beds are assumed to dip at a high angle; but the writer considers that the thickness is probably at least 2,000 feet. Beyond the diorite in the NE1/4 SE $1 / 4$ sec. 15, T. 46 N., R. 29 W. (pl. $2)$, three holes were drilled in sericitic argillite interpreted to be Mahnomen formation. These holes are more than a mile from the nearest Trommald formation and are nearly a third of the distance to the South range. If the entire area between the two ranges is underlain by Mahnomen formation, it seems that, though drag folded, the total thickness of the formation may greatly exceed 2,000 feet.

Samples of the Mahnomen formation were examined from 33 drill holes in the general area north of the Maroco and Section Six mines in secs. 5 and 6 , T. 46 N., R. 29 W., and south and west of the Merritt mine in secs. 31 and 32, T. 47 N., R. 29 W. (pl. 3). As in other localities, the quartzite so conspicuous in the exposures in the Maroco and Section Six mines is actually a minor rock occurring interbedded with argillite or slate in the uppermost 100 to perhaps 1,000 feet of the formation. Most of the samples from the 33 drill holes are sericitic argillite, silty argillite, and fine siltstone.

Wolff has shown an area underlain by "pre-Animikie slates and schists" in the middle of the area discussed in the previous paragraph. The samples examined by the writer included those from five holes in this supposedly older unit; one hole was in sec. 6, two were in sec. 5, and two were in sec. 32 . The samples are argillite and slate identical to the surrounding Mahnomen formation. If such an older unit exists, it must occupy a smaller area than Wolff shows.

Other drill holes that provided good samples relatively great thicknesses of Mahnomen formation were located in several places in the North range: between the Maroco mine and the south-central part of sec. 33, T. 47 N., R. 29 W. (pl. 3); between the iron-

constituents of Cuyuna district rocks

magnitude, $x+$ indicating the higher portion (10 to 5 percent); $x$ the middle portion ( 5 to 2 percent) and $x-$ the lower portion ( 2 to 1 percent). Comparisons of this type show that the assigned group includes the quantitative value in about 60 percent of the analyses]

\begin{tabular}{|l|l|l|l|l|l|l|l|l|l|l|l|l|l|l|l|l|l|l|l|l}
\hline $\mathrm{Co}$ & $\mathrm{Cr}$ & $\mathrm{Cu}$ & $\mathrm{F}$ & $\mathrm{Ga}$ & $\mathrm{Ge}$ & $\mathrm{La}$ & $\mathrm{Mo}$ & $\mathrm{Nb}$ & $\mathrm{Nd}$ & $\mathrm{N} 1$ & $\mathrm{~Pb}$ & $\mathrm{Sc}$ & $\mathrm{Sr}$ & $\mathrm{V}$ & $\mathrm{Y}$ & $\mathrm{Yb}$ & $\mathrm{Zn}$ & $\mathrm{Zr}$ & $\mathrm{eU}$ \\
\hline
\end{tabular}

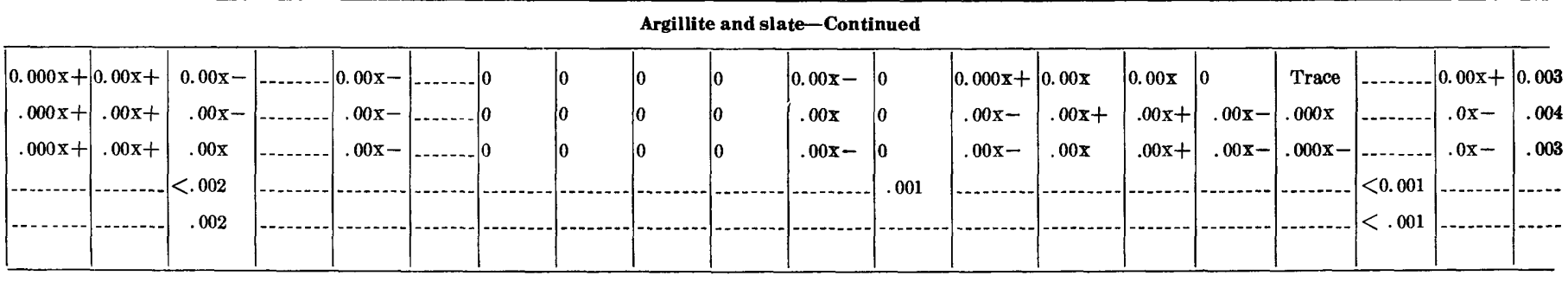

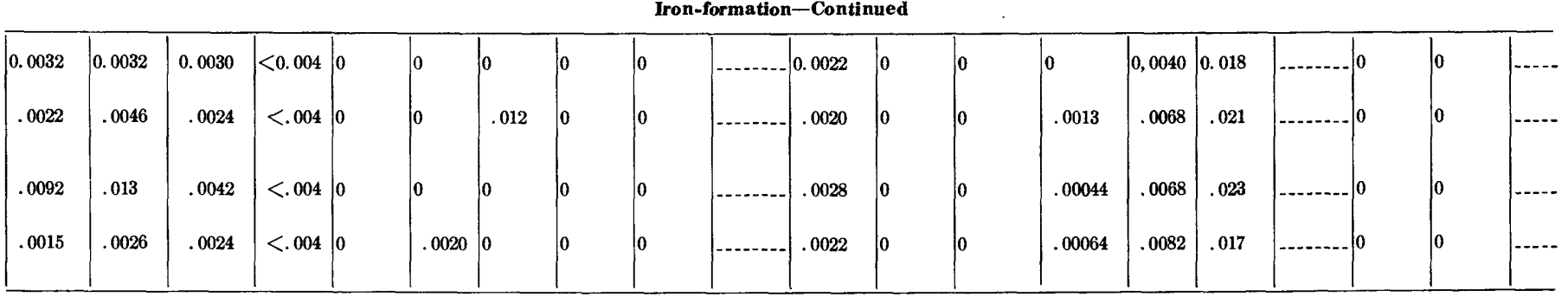

Argillaceous lenses within iron-formation-Continued

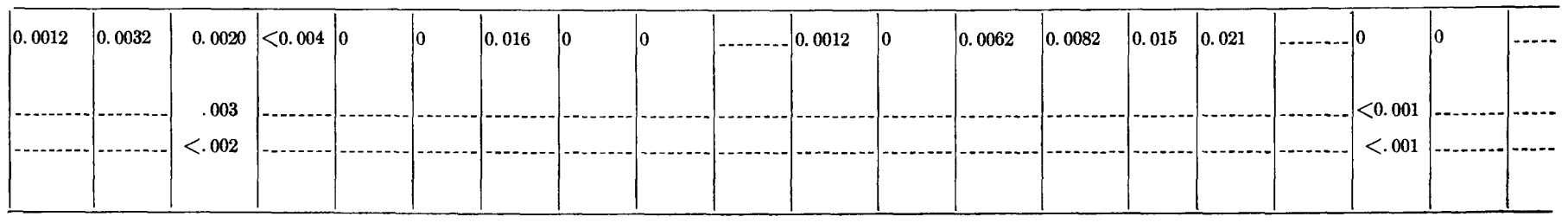


TABLE 2.-Analyses of minor

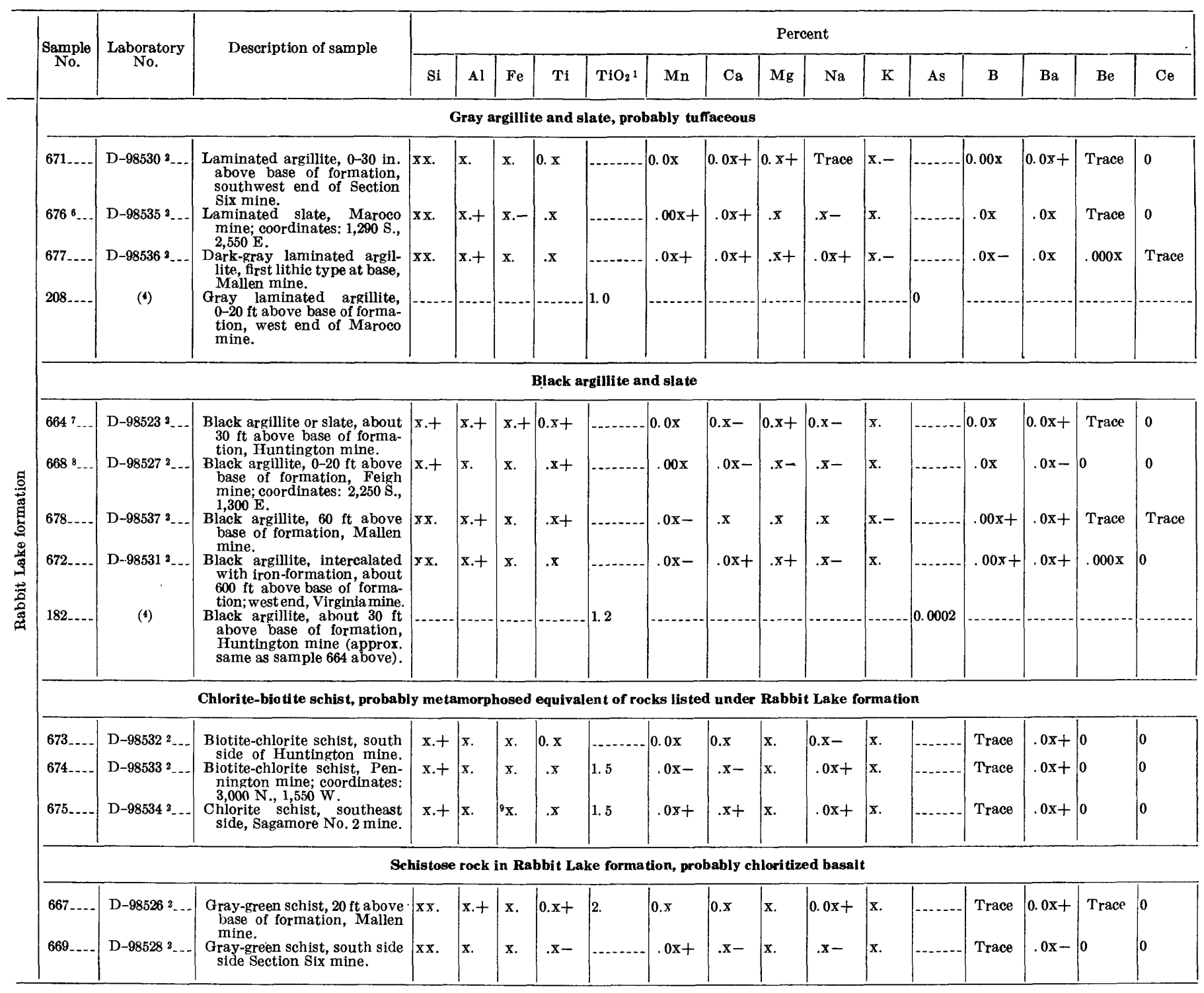

$1 \mathrm{TiO}_{2}$ by rapid chemical method, R. G. Schmidt, analyst.

2 Semiquantitative spectrographic method, G. W. Boyles, Jr., analyst; radiometric method for eU, S. P. Furman, analyst.

3 Compare complete analysis sample 173 , , G. W.

4 Rapid chemical method, analyses by Geochemical Prospecting Unit, Denver.

5 Quantitative spectrographic methods, H. J. Rose, Jr., and K. J. Murata, analysts; chemical methods $\rightarrow$ fluorine, Blanche Ingram, analyst; arsenic, J. K. MeCarthy, analyst.

formation under the northeast end of Menomin Lake and the Pontiac shaft (pl. 3) ; in a northwest-trending row near the center of sec. 36, T. 47 N., R. 29 W. (pl. 2); under the village of Crosby in the south half of sec. 11, T. 46 N., R. 29 W. (pl. 3); and in a large sparsely drilled area east of the Rabbit Lake mine in secs. $21,22,28$, and 29 , T. 47 N., R. $28 \mathrm{~W}$. (pl. 2).

\section{TROMMALD FORMATION}

The main iron-formation of the Cuyuna district, which is here named the Trommald formation from the village of Trommald, is a distinct stratigraphic unit throughout the North range. The type area is designated as the drill holes and mines near Trommald. This unit is probably correlative with the Biwabik iron-formation of the Emily district (White, 1954) and also with the lron-formation of the Cuyuna South range. Most of the iron ore in the district has formed as a result of alteration of this formation.

The Trommald formation of middle Precambrian age is a stratigraphic unit in which most of the constituents--quartz and iron minerals: oxides, carbonates, and silicates-have been derived by precipita- 
constituents of Cuyuna district rocks-Continued

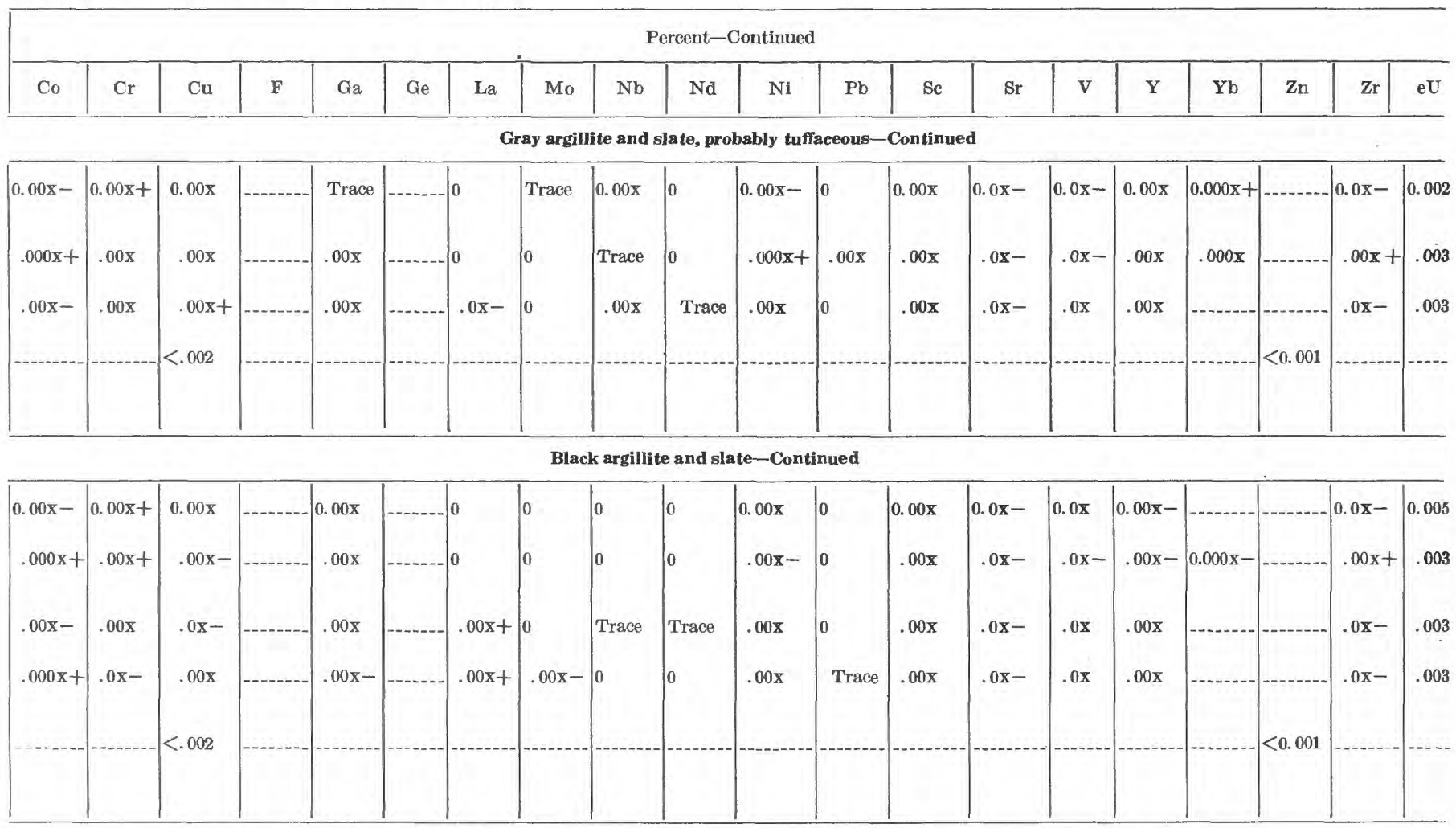

Chlorite-biotite schist, probably metamorphosed equivalent of rocks listed under Rabbit Lake formation-Continued

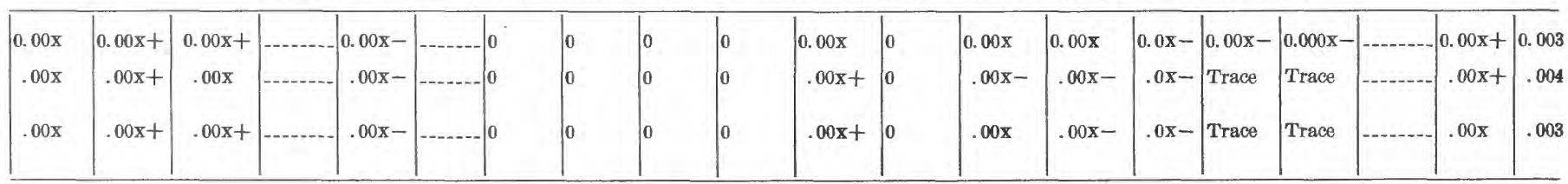

Schistose rock in Rabbit Lake formation, probably chloritized basalt-Continued

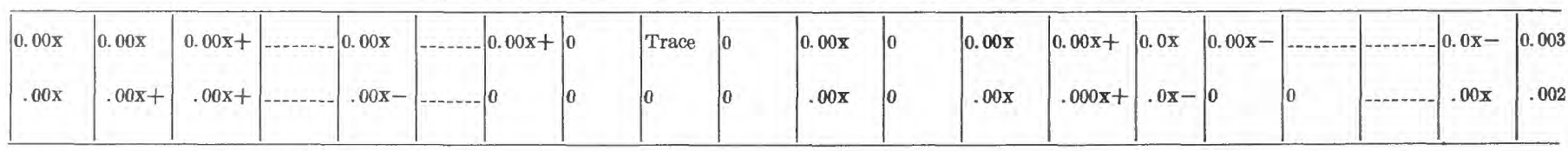

${ }^{6}$ Compare complete analysis sample 174 , table 7.

7 Compare complete analysis samples 154 and $\mathbf{H} \mathbf{J}-14$, table 7.

- By rapid chemical method, Fe, 5 percent, $R$. G. Schmidt, analyst.

Note.-A zero in the analysis column indicates that element was looked for, but not found by method used.

tion from aqueous solution or from colloidal suspension and in which clastic constituents are for the most part subordinate or absent. Most of the iron-formation, though not all, contains fine-grained crystalline quartz that presumably originated as a chemical precipitate and has since crystallized during metamorphism. As in other parts of the Lake Superior region, this quartz is known as "chert." The size of quartz grains from chert in the Cuyuna district ranges from about 0.01 to $0.15 \mathrm{~mm}$; occasionally individual grains much larger are observed.
Part of or all the iron in many of the minerals of the Trommald formation is in the ferrous or lower valence state, having been deposited in an environment deficient in oxygen, and such rock is collectively called unoxidized iron-formation. Oxidized iron-formation is that in which the iron minerals contain mostly ferric or higher valence iron. Part of the oxidized iron-formation was probably deposited in this state, but much of it has been formed by the oxidation of the minerals in previously unoxidized ironformation. 
Locally, only iron analyses of drill-hole samples were available for mapping iron-formation, and it was necessary to use an arbitrary lower limit of 20 percent iron for iron-formation. In the logging of drill cores, a few cores of ferruginous chert that consisted of an iron mineral and quartz with practically no clastic material were designated as iron-formation even though the iron analyses were less than 20 percent.

The characteristics of the Trommald formation are complicated by relatively abrupt but systematic changes in thickness, in minerals, and in physical appearance; on the basis of these changes, the formation has been divided into two mappable facies. The thick-bedded facies constitutes the entire Trommald formation in part of the North range; the thin-bedded facies makes up the entire formation in another part; and in about a third of the North range, the thickbedded facies overlies the thin-bedded facies (pls. $5,6)$ and grades downward into it. Plate 6 is a group of composite sections each prepared by examining the samples of many close-spaced drill holes selected to show some typical systematic variations in the Trommald formation.

\section{THIN-BWDDED FACIES}

The thin-bedded facies of the Trommald formation is characterized by individual bedding laminae that are less than half an inch thick; many laminae are less than one-eighth inch thick, and some can be distinguished only with a lense of microscope (fig. 2).

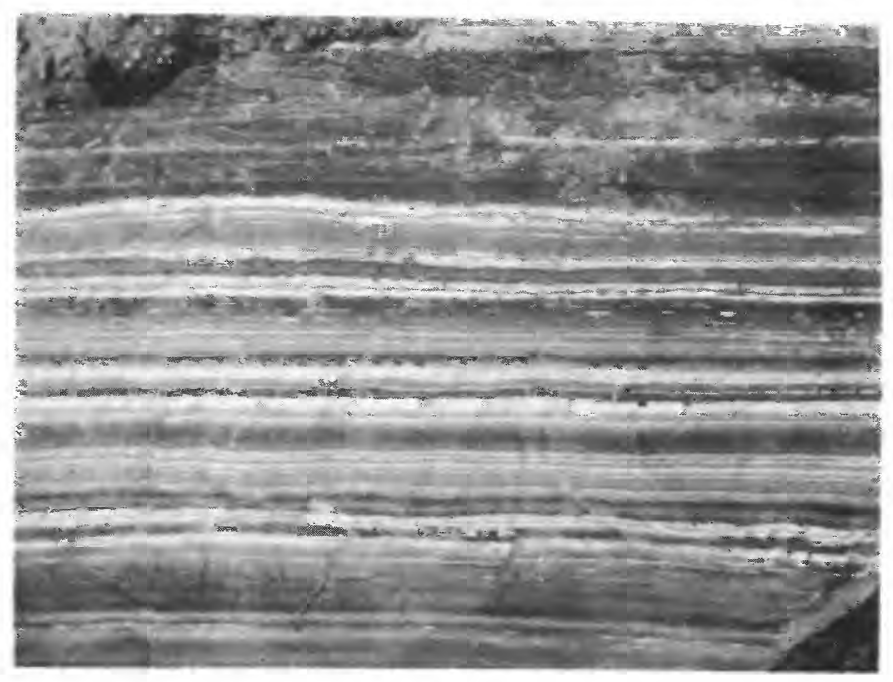

FrgurE 2.-Unoxidized thin-bedded Trommald formation, northwest side of Portsmouth mine, SE $1 / 4$ SE $1 / 4$ sec. 2, T. 46 N., R. 29 W.

In one typical piece, 220 layers in a thickness of 12 inches could be distinguished by the unaided eye. Chert lenses that are several inches thick and chert beds that are as much as $\mathbf{1 0}$ feet thick have been found locally, but they are subordinate and generally not present except in the zone of transition to the thickbedded facies.

Eighteen chemical analyses of the thin-bedded facies are given in table 3 . The analyses show that there is considerable variation in the ratio of ferrous to ferric iron and in the amount of manganese in the rock, but there is a generally consistent relation between iron plus manganese and the other constituents, except carbon dioxide and silica. Beds of nearly pure chert that are several feet thick may be found, but only thin laminae occur without much silica. No considerable thickness of unoxidized iron-formation that has much more iron and manganese than the analyses given here is found in the district.

The principal minerals in the unoxidized thinbedded facies are quartz, siderite, magnetite, stilpnomelane, minnesotaite, and chlorite. Grunerite and tourmaline occur locally. Acmite was described from a drill hole and underground workings at the Merritt mine by Grout (1946a). The minerals have been considerably changed where the facies has been oxidized. Iron ore has developed in the oxidized ironformation where removal of silica and magnesia has been sufficient to cause proportional increase of the iron as oxide in the residue above a certain economically determined minimum.

Complete stratigraphic sections of the unoxidized iron-formation are not exposed in the mines, and it has not been possible to determine the original mineral content in the iron-formation from bottom to top for any one location. Specimens were collected wherever unoxidized iron-formation was observed, and the stratigraphic positions of the sites were estimated as closely as possible. Although it was possible to estimate the approximate proportions of the minerals present in 35 of the 45 thin sections examined, no orderly distribution of minerals in the unoxidized thin-bedded facies was found. There are no stratigraphic markers within the thin-bedded facies except for the intermediate argillite ("paint rock") at the Sagamore mine (pl. 4), and many of the estimated stratigraphic positions elsewhere probably are somewhat in error. Comparing stratigraphic successions assembled in this fashion, the mineral content of the iron-formation was found to be as irregularly varied from top to bottom as laterally.

Silicates, carbonates, and magnetite each make up various proportions of the facies in all parts of the district and from the bottom to the top of the unit. The unoxidized iron-formation is most uniform in the Sagamore mine. Five thin sections examined con- 
TABLE 3.-Chemical analyses of 18 samples from the unoxidized thin-bedded facies of the Trommald formation

\begin{tabular}{|c|c|c|c|c|c|c|c|c|c|c|c|c|c|c|c|c|c|c|}
\hline & 34 & 35 & 36 & 37 & 155 & 160 & 161 & 932 & 936 & 1039 & 1426 & HJ-6 & НJ-7 & HJ-8 & HJ-13 & G-1 & G-2 & G-3 \\
\hline $\mathrm{SiO}_{2} \ldots \ldots$ & 28.5 & 24.2 & 24.8 & 25.5 & 35.1 & 32.5 & 32.8 & 31.72 & 34.69 & 33.54 & 28.75 & 30.15 & 32.10 & 59.32 & 40.70 & 26.20 & 28.14 & 34.92 \\
\hline $\mathrm{Al}_{2} \mathrm{O}_{3} \ldots$ & 1.8 & 1.9 & 2.7 & 3.4 & 2.6 & 2.0 & 1.5 & 1.30 & 1. 77 & 2.83 & 2.19 & 0.40 & 4.85 & 0.79 & 2.24 & 4.82 & 2.70 & 1.65 \\
\hline $\mathrm{Fe}_{2} \mathrm{O}_{3}$ & .10 & 1.3 & 2.4 & 3.5 & 10.4 & 2.1 & 24.5 & 8.56 & 5.45 & 11.29 & 3.56 & 5.27 & 16.00 & 1.51 & $12.15\}$ & & & \\
\hline $\mathrm{FeO}$ & 32.3 & 31.6 & 28.3 & 29.0 & 31.2 & 27.8 & 22.9 & 32.48 & 28.18 & 22.04 & 32.77 & 31.34 & 17.33 & 16.42 & 24. 54$\}$ & 126.55 & 125.86 & 122.31 \\
\hline $\mathrm{MgO}$ & 4.3 & 5.2 & 3.8 & 4.0 & 2.8 & 4. 1 & 1.8 & 3. 25 & 2.84 & 3.30 & 2.11 & 4. 77 & 5. 74 & 4. 38 & 2.77 & 4.92 & 2.05 & 2.72 \\
\hline $\mathrm{CaO}$ & 1.1 & 1.3 & 1.1 & 1.0 & .16 & .88 & 1.2 & 1.31 & 3.72 & .72 & 1.10 & 1.25 & 5. 73 & .41 & 1. 28 & 1.92 & 1.34 & 1.12 \\
\hline $\mathrm{Na}_{2} \mathrm{O}$ & .09 & .08 & .09 & .12 & .14 & .14 & .11 & .03 & .06 & .06 & .06 & $-\cdots$ & - & $\ldots$ & & & & \\
\hline $\mathbf{K}_{2} \mathbf{O}$ & .06 & .11 & .50 & .57 & .52 & .44 & .38 & .16 & .31 & .67 & .41 & & & -. & . & & & . \\
\hline $\mathrm{H}_{2} \mathrm{O}-$ & & $\ldots$ & $\ldots$ & $\ldots$ & $-\ldots$ & $\ldots$ & $\ldots$ & .13 & .16 & 1. 38 & .55 & & & & & & & \\
\hline $\mathrm{H}_{2} \mathrm{O}+$ & $\ldots$. & $\ldots$. & - & $\ldots$ & $\ldots$ & - & - & 2.38 & 3.00 & 2.65 & 1.76 & .36 & 3.14 & .25 & & & & \\
\hline $\mathrm{TiO}_{2}$ & .07 & .05 & .07 & .11 & .07 & .10 & .13 & .02 & .05 & .08 & .34 & .02 & .13 & Trace & Trace & & & \\
\hline $\mathrm{CO}_{2}$ & $\ldots$ & $\ldots$ & $\ldots$ & $\ldots$ & -..- & $\ldots$ & $-\ldots$ & 14.50 & 12.82 & 15.29 & 18.00 & 24.65 & 8. 68 & 14.06 & 10.21 & 14.06 & 14.38 & 13. 40 \\
\hline $\mathrm{P}_{2} \mathrm{O}_{5}$ & .37 & .32 & .31 & .37 & .52 & .32 & .48 & .70 & .25 & .04 & .09 & .665 & 4. 019 & 0.057 & 0.572 & 2.224 & 2.193 & 2.063 \\
\hline MnO & 6.1 & 9.4 & 11.2 & 12.9 & 2.8 & 9.3 & 3.3 & 2.99 & 6.61 & 6.40 & 8.40 & & & & $\ldots$ & - & ............ & - \\
\hline & & & & & & & & & & & 4.07 & 2.53 & ${ }^{5} 1.28$ & 52.27 & $\begin{array}{r}3.40 \\
36.44\end{array}$ & 6 4.14 & 67.99 & 69.10 \\
\hline Total... & 74.8 & 75.4 & 75.3 & 80.5 & 86.3 & 79.7 & 89.1 & 99.53 & 99.91 & 100.29 & 100.16 & 101.40 & 99.00 & 99.47 & 101.30 & 82.83 & 82,65 & 85.28 \\
\hline \multirow{3}{*}{\multicolumn{5}{|c|}{$\begin{array}{l}\text { Germanium (chemical analyses) } \\
\text { Boron (spectrographic analyses) } \\
\text { Loss on ignition }\end{array}$}} & 1.5 & & & & & & & & & & & & & \\
\hline & & & & & .005 & & & 0.002 & 0.002 & 0.005 & 0 & & & & & & & \\
\hline & & & & & $\ldots$ & & & . & & - & -....... & 20.65 & 8.60 & 12.06 & 9.00 & & & \\
\hline
\end{tabular}

\section{Fe.}

$2 \mathrm{P}$.

Graphite.

Sample:

34. Chert-siderite iron-formation, only traces of chlorite and other silicates present. Grab sample, North Hillcrest mine, 5-10 ft from base of Trommald formation; coordinates: $1,450 \mathrm{~S} ., 870 \mathrm{~W}$., alt, about 1,113 ft. Collected June 1952. Lab. No. 52-1415CW. S. M. Berthold, U.S. Geol. Survey, analyst.

35. Chert-siderite iron-formation, grab sample near base of Trommald formation. Alstead mine; coordinates: 1,630 S., 1,800 W., alt, about 1,078 ft. Collected June 1952. Lab. No. 52-1416CW. S. M. Berthold, U.S. Geol. Survey, analyst.

36. Channel sample of $5 \mathrm{ft}$ of laminated silicate-carbonate iron-formation cut perpendicular to bedding. Silicates are minnesotaite, ferrostilpnomelane, lesser amount of ferristilpnomelane. Compare with 37. North Hillerest mine; coordinates: $1,070 \mathrm{~S} ., 800 \mathrm{~W}$., alt, about 1,118 ft. Collected June 1952. Lab. No. 52-1417CW. S. M. Berthold, U.S. Geol. Survey, analyst.

37. Same rock as 36 . Five-ft channel sample cut perpendicular to bedding; stratigraphically below 36 and extension of same channel. Alt, about 1,113 ft. Collected June 1952. Lab. No. 52-1418CW. S. M. Berthold, U.S. Geol. Survey, analyst.

155. Minnesotaite-carbonate iron-formation. Distinctly laminated; light layers are almost all minnesotaite; dark layers are minnesotaite, carbonate, minor amounts of ferristilpnomelane and magnetite. Whole rock is more than 80 percent silicate. Grab sample from Feigh mine; coordinates: 2,830 S., 1,110 E., ait, about 1,103 ft. Collected June 1952. Lab. No. 52-1420CW. S. M. Berthold, U.S. Geological Survey, analyst; germanium analysis by Peter Zubovic, and boron analysis by Harry Bastron, U.S. Geol. Survey.

160. Laminated iron-formation. Grab sample Sagamore No. 2 mine; coordinates: 3,480 S., 4,050 W., alt, 1,085 it. Collected June 1952. Lab. No. 52-1425C W. S. M. Berthold, U.S. Geol. Survey, analyst.

161. Laminated iron-formation, probably magnetite rich. Grab sample, Mabnomen No. 1 mine; coordinates: 500 S., 1,500 E. Collected June 1952. Lab. No. 52-1426C W. S. M. Berthold, U.S. Geol. Survey, analyst.

932. Silicate-carbonate iron-formation. Rock also contains magnetite and minor amounts of hematite, goethite, stilpnomelane, and perhaps carbon. Channel sample perpendicular to bedding, about $3 \mathrm{ft}$ long. Portsmouth mine; coordinates: 3,260 N., 1,740 E. Collected August 1953. Lab. No. 54-67CD.
4 Organic material.

5 Total manganese calculated as $\mathrm{Mn}_{2} \mathrm{O}_{3}$.

o Mn.

L. N. Tarrant, U.S. Geol. Survey, analyst: boron analysis by P. R. Barnett, U.S. Geol. Survey.

936. Carbonate-silicate iron-formation. Grab sample, Arko mine; coordinates: 1,150 W., 550 S. Collected August 1953. Lab. No. 54-70CD. L. N. Tarrant, U.S. Geol. Survey, analyst; boron analysis by P. R. Barnett, U.S. Geol. Survey.

1039. Laminated iron-formation, 30-in. channel sample cut perpendicualr to bedding. Contains stilpnomelane, siderite, and quartz. Sagamore No. 2 mine; coordinates: 3,230 S., 3,770 W. Collected 1953. Lab. No. 54-72CD. L.N. Tarrant, U.S. Geol. Survey, analyst; boron analysis by P. R. Barnett, U.S. Geol. Survey.

1426. Carbonate-silicate iron-formation. Rock is roughly 60 percent carbonate, 20 percent minnesotaite, and 20 percent probably greenalite. Mahnomen No. 2 mine; coordinates: 4,380 N., 3,700 W., Collected October 1956 . Lab. No. 151456. S. M. Berthold, U.S. Geol. Survey, analyst; boron analysis by Sol Berman, U.S. Geol. Survey.

HJ-6. Fine-grained light-gray siliceous iron-carbonate rock from Kennedy mine. J. H. McCarthy, School of Mines Experiment Station, University of Minnesota, analyst. Reference: Harder and Johnston (1918, p. 120).

HJ-7. Dense dark-gray argillaceous iron-carbonate rock from Kennedy mine. J. H. McCarthy, School of Mines Experiment Station, University of Minnesota, analyst. Reference: Harder and Johnston (1918, p. 120).

HJ-8. Greenish-gray banded cherty iron-carbonate rock from Kennedy mine. J. H. McCarthy, School of Mines Experiment Station, University of Minnesota, analyst. Reference: Harder and Johnston (1918, p. 120).

HJ-13. Green amphibolite slate from Mangan No. 2 mine. J. H. McCarthy, School of Mines Experiment Station, University of Minnesota, analyst. Reference: Harder and Johnston (1918, p. 120).

"Amphibole" implied in name was probably stilpnomelane or minnesotaite, as these minerals were not recognized in the iron-formation when Harder and Johnston studied the district.

G-1. "Carbonate slate"; trench, north part of Sagamore pit. Reference: Grout (1942, p. 44).

G-2. "Carbonate slate"; north wall Arko pit, 1941. Reference: Grout (1942, p. 44).

G-3. "Carbonate slate"; crosscut, Merritt mine, 178-ft level. Reference: Grout (1942, p. 44). 
tained silicates and siderite as the principal ironbearing minerals, and the siderite ranged from about 40 to 90 percent of the iron-bearing mineral. In other parts of the district, the variations in the minerals were generally greater. Material examined from near the bottom of the Trommald formation in the Alstead mine contained little else but siderite. At a short distance to the east on the south side of the North Hillcrest mine, material from the same stratigraphic position contained quartz and siderite. On the north side of the North Hillcrest mine and still in approximately the same stratigraphic position, the iron-formation consisted largely of minnesotaite, stilpnomelane, and siderite. In the Mahnomen No. 1 mine, part of the iron-formation near the base contains 30 to 40 percent magnetite, though none was found at the base in the Alstead or North Hillcrest mines.

Locally, the amount of fine quartz ("chert") in the thin-bedded iron-formation varied in a more regular fashion than the iron-bearing minerals. Over a considerable area that includes the Alstead, North Hillcrest, Hillcrest Extension, and Mahnomen Nos. 2 and 3 mines, and perhaps the Louise open pit, the base of the main iron-formation is marked by a single bed of chert that is 2 to 10 feet thick. In the Mahnomen No. 1 mine this same stratigraphic interval is a persistent layer of very cherty thin-bedded iron-formation that is 4 to 30 feet thick.

At the Sagamore mine a layer about 20 feet thick at the top of the Trommald formation along the south bank of the No. 2 pit (pl. 4) contains considerably more interlaminated chert than the iron-formation stratigraphically underlying it. Some layers contain mottled textures characteristic of the thick-bedded facies, indicating that these beds probably represent the extreme edge of the thick-bedded facies.

Stylolites are rare in the Trommald formation, but they were seen in a few pieces of core from the thinbedded facies.

X-ray powder patterns were obtained from 25 samples of ore and partly oxidized material from the thin-bedded facies of the main iron-formation. Goethite and hematite were the most abundant ore minerals, and although some ores had each of the minerals virtually without the other, most ores were mixtures of the two. Manganite was detected in three ores although it was not visible to the eye. Other manganese minerals in material hand picked from the enclosing ore included groutite in many specimens, manganite, pyrolusite, and cryptomelane. No psilomelane was found in any of the samples. Ores contained various amounts of quartz.
Partly oxidized iron-formation contained nontronite, quartz, and siderite, lesser amounts of minnesotaite, stilpnomelane, and possibly biotite. Chemical analyses of partly oxidized thin-bedded iron-formation and ore are given in tables 2 and 4 .

\section{THICK-BEDDED FACIES}

Chert and intermixed iron oxides in relatively massive beds 1 or 2 inches to 6 feet thick characterize the thick-bedded facies of the Trommald formation. Two subfacies have been differentiated in mapping. The straight-bedded rock has prominent persistent cherty beds that are about 6 inches to 6 feet thick and are separated by a few inches to a few feet of thinbedded iron-formation. There were excellent exposures of this type of rock in the Joan No. 1 and Arko mines (fig. 3). The wavy-bedded rock has alternating cherty and ferruginous beds that are 1 inch to 1 foot thick; the thickness of the beds varies in a short distance along strike, and individual beds that are several inches thick may pinch out in a few feet. Variations in the thickness of the individual beds give the general appearance of waviness to the bedding (fig. 4). The wavy-bedded iron-formation makes up all the Trommald formation in the Maroco and Section Six mines, and the two subfacies were seen together only in the Mangan No. 1 and Joan No. 1 pits. The thick-bedded iron-formation contains primarily hematite, goethite, and quartz; minor amounts of carbonate, magnetite, chlorite, and stilpnomelane; and probably other iron silicates. Oxidized thick-bedded iron-formation contains goethite, hematite, and quartz. A chemical analysis is given in table 5 . The absence

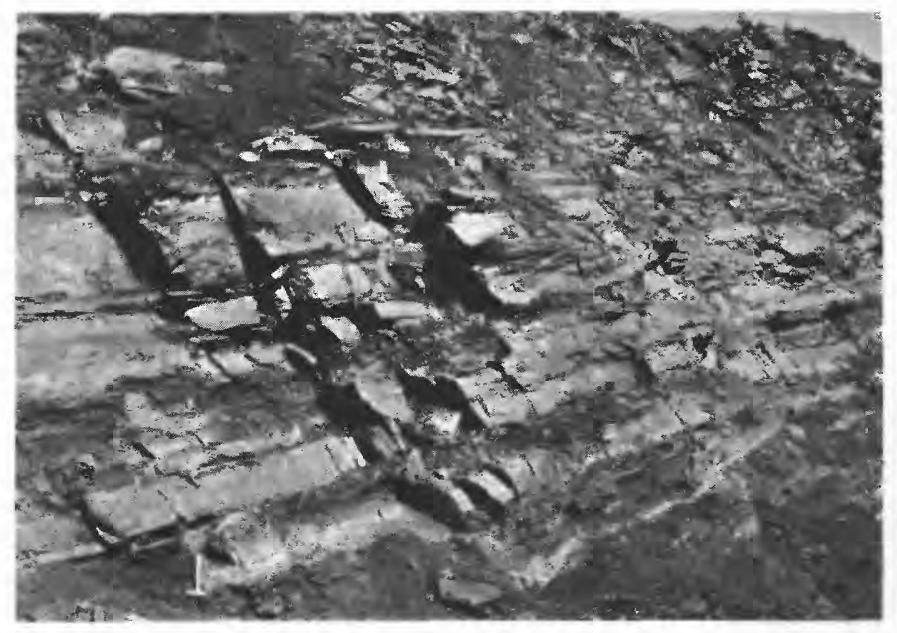

Figure 3.-Straight-bedded subfacies, thick-bedded Trommald formation, northeast end of Joan No. 1 mine. Beds dip into the bank about $40^{\circ}$. The light layers are single hard cherty beds; dark layers are softer decomposed thin-bedded material. 
$\mathrm{T}_{\mathrm{ABLE}}$ 4.-Chemical analyses of samples of partly altered iron-formation and ores from the thin-bedded facies of the Trommald formation

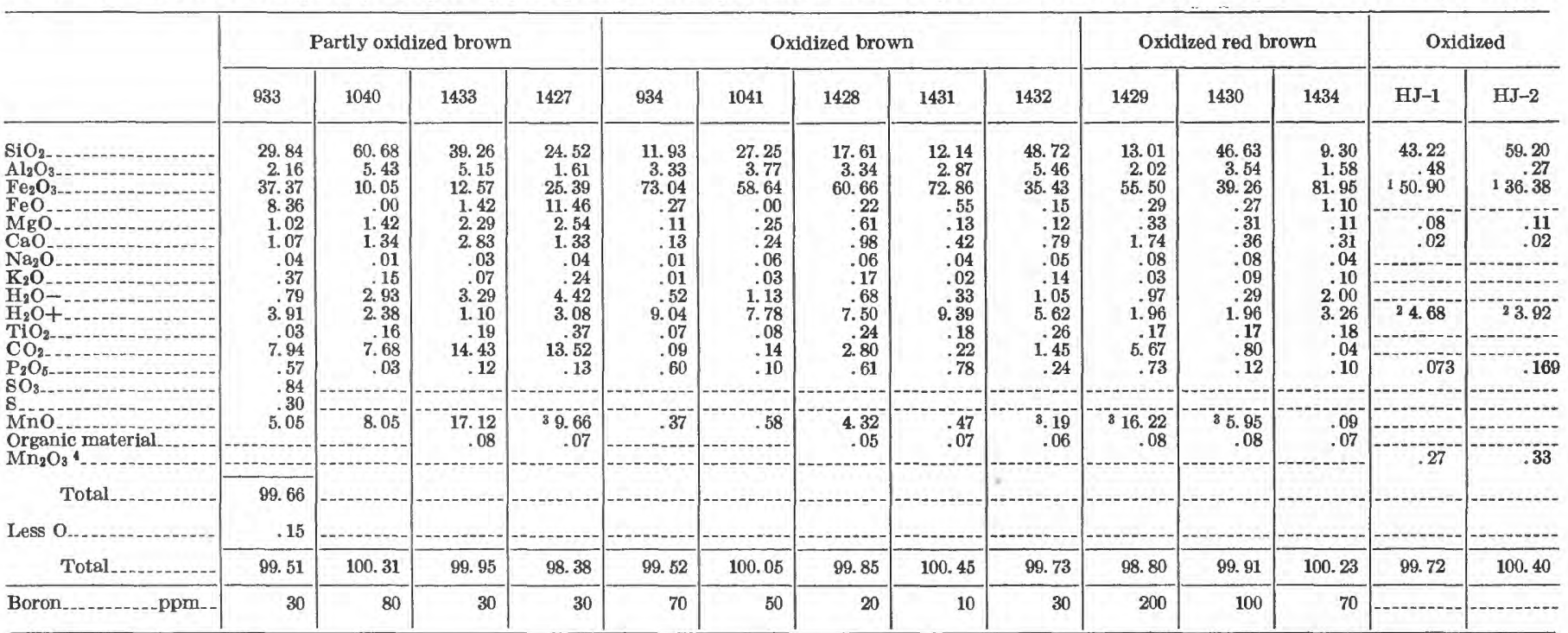

1 Total iron calculated as $\mathrm{Fe}_{2} \mathrm{O}_{3}$.

2 Loss on ignition, essentially molecular $\mathrm{H}_{2} \mathrm{O}$.

Sample:

933. Partly oxidized thin-bedded iron-formation, channel sample about $5 \mathrm{ft}$ long measured perpendicular to bedding. Exact stratigraphic equivalent of sample 934 and derived from material similar to sample 932 (table 3 ). Contains goethite, quartz, siderite, probably magnetite, and perhaps hematite. Portsmouth mine; coordinates: 3,335 N., 1,775 E. Collected August 1953. Lab. No. 54-68CD. L. N. Tarrant, U.S. Geol. Survey, analyst; boron analysis by P. R. Barnett, U.S. Geol. Survey.

1040. Soft partly oxidized nontronitic laminated iron-formation, 30-in. channel sample cut perpendicular to bedding. Exact stratigraphic equivalent of samples 1039 and 1041. Rock contains nontronite, manganosiderite, quartz stilpnomelane, and goethite. Sagamore No. 2 mine; coordinates: $3,230 \mathrm{~S}$. 3,770 W. Collected 1953. Lab. No. 54-73CD. L. N. Tarrant, U.S Geol Survey, analyst; boron analysis by P. R. Barnett, U.S. Geol Survey.

1433. Soft yellow-brown iron-formation, 4-in. channel is exactly equivalent stratigraphically to sample 1434. Contains nontronite, rhodochrosite, and quartz, and probably goethite. Lab. No. 151463. S. M. Berthold, U.S. Geol. Survey, analyst; boron analysis by Sol Berman, U.S. Geol. Survey.

1427. Brown oxidized iron-formation, 18-in. channel sample cut perpendicular to bedding. Exact stratigraphic equivalent of sample 1426 (table 3 ). Rock contains minnesotaite, nontronite, siderite, quartz, and stilpnomelane, and possibly biotite. Mahnomen No. 2 mine; coordinates: 4,380 N. 3,700 W. Collected October 1956. Lab. No. 151457. S. M. Berthold, U.8. Geol. Survey, analyst; boron analysis by Sol Berman, U.S. Geol Survey.

934. Brown oxidized iron-formation, channel sample about $5 \mathrm{ft}$ long perpendicular to bedding. Exact stratigraphic equivalent of sample 933 and derived from material similar to sample 932 (table 3). Minerals identified were goethite, quartz, and a trace of hematite. Portsmouth mine; coordinates: 3,335 N., 1,775 E. Collected August 1953. Lab. No. 54-69CD. L. N. Tarrant, U.S. Geol. Survey, analyst; boron analysis by P. R. Barnett, U.S. Geol. Survey.

1041. Gnarled ore, 30-in. channel sample cut perpendicular to bedding. Exact stratigraphic equivalent of samples 1039 (table 3 ) and 1040. Rock contains goethite, quartz, and perhaps a trace of hematite. Sagamore No. 2 mine; coordinates: 3,230 \$., 3,770 W. Collected summer 1953. Lab. No. 54-74CD. L. N. Tarrant, U.S. Geol. Survey, analyst; boron analysis by P. R. Barnett, U.S. Geol. Survey.

1428. Brown oxidized iron-formation; grab sample over about $3 \mathrm{ft}$ of beds. Roughly the same stratigraphic interval as sample 1429. Rock includes both laminated and gnarled "ore"; both contain goethite, quartz, and a small amount of unknown mineral. The goethite in the laminated ore shows a higher degree of crystallinity than that in the gnarled ore. Mahnomen No. 2 mine; coordinates: 4,100 N., 3,900 W. Collected October 1956. Lab. No. 151458. S. M. Berthold, U.S. Geol. Survey, analyst; boron analyses by Sol Berman, U.S. Geol, Survey.
${ }^{3}$ Qualitative tests indicate that the manganese is present as $\mathrm{MnO}_{2}$ as well as $\mathrm{MnO}$. This presumably accounts for the low summation reported on these samples. 4 Total manganese calculated as $\mathrm{Mn}_{2} \mathrm{O}_{3}$.

1431. Hard, brittle, brown ore simllar to that found in rind rock (p. 59), immedi ately adjacent to red-brown zone along joints; 15 -in. channel sample perpendicular to beds. Exact stratigraphic equivalent of samples 1430 and 1432 and rough equivalent of samples 36 and 37 (table 3). Rock contains goethite with good crystallinity and quartz. North Hillcrest mine; coordinates: 1,060 S., $580 \mathrm{~W}$. Collected October 1956. Lab. No. 151461. S. M. Berthold, U.S. Geol. Survey, analyst; boron analysis by Sol Berman, U.S. Geol. Survey

1432. Soft yellow-brown laminated ore; 15 -in. channel sample perpendicular to beds. Exact stratigraphic equivalent of samples 1430 and 1431 and rough equivalent of samples 36 and 37 (table 3). Rock contains goethite with good crystallinity, quartz, and a minor amount of unknown mineral. North Hillcrest inine; coordinates: 1,060 S., $580 \mathrm{~W}$. Collected October 1956. Lab. No. 151462. S. M. Berthold, U.S. Geol. Survey, analyst; boron analysis by Sol Berman, U.S. Geol. Survey.

1429. Soft and hard red ore, concretionary and laminated; grab sample over about $3 \mathrm{ft}$ of beds. Roughly the same stratigraphic interval as sample 1428. Rock contains goethite, hematite, quartz, and manganite. Mahnomen No. 2 mine; coordinates: 4,100 N., 3,900 W. Collected October 1956. Lab. No. 151439. S. M. Berthold, U.S. Geol. Survey, analyst; boron analysis by Sol Berman, U.S. Geol. Survey.

1430. Hard red-brown ore, partly laminated and partly massive with conchoidal fracture; from red-brown zone along joints; 15-in. channel sample perpendicular to beds. Exact stratigraphic equivalent of samples 1431 and 1432 and rough equivalent of samples 36 and 37 (table 3). Rock contains poorly crystallized goethite, quartz, and probably a minor unknown mineral, also probably hematite in the redder parts of the sample. North Hillcrest mine; coordinates: $1,060 \mathrm{~S}$., $580 \mathrm{~W}$. Collected October 1956. Lab. No. 151460. S. M. Berthold, U.S. Geol. Survey, analyst; boron analysis by Sol Berman, U.S. Geol. Survey.

1434. Hard red-brown cindery ore with conchoidal fracture from thin stringers of red-brown ore cutting soft yellow-brown iron-formation along joints and bedding planes (fig. 17); 4-in. channel sample is immediately adjacent to, and exact stratigraphic equivalent of, sample 1433 and rough equivalent of samples 36 and 37 (table 3). Rock contains poorly crystalline hematite and quartz. North Hillcrest mine; coordinates: 1,060 S., 590 W. Collected October 1956. Lab. No. 151464. S, M. Berthold, U.S. Geol. Survey, analyst; boron analysis by Sol Berman, U.S. Geol. Survey.

HJ-1. Banded ferruginous chert, Kennedy mine. J. H. McCarthy, School of Mines Experiment Station, University of Minnesota, analyst. Reference: Harder and Johnston (1918, p. 120, column 1).

HJ-2. Ferruginous chert consisting of irregularly intermixed chert and iron oxide, Thompson mine. J. H. McCarthy, School of Mines Experiment Station, University of Minnesota, analyst. Reference: Harder and Johnston $(1918$, p. 120, column 2) 
of ferrous iron is probably typical of the altered material found in the mines, but fresher rock is common in drill hole samples and doubtless contains measurable ferrous iron.

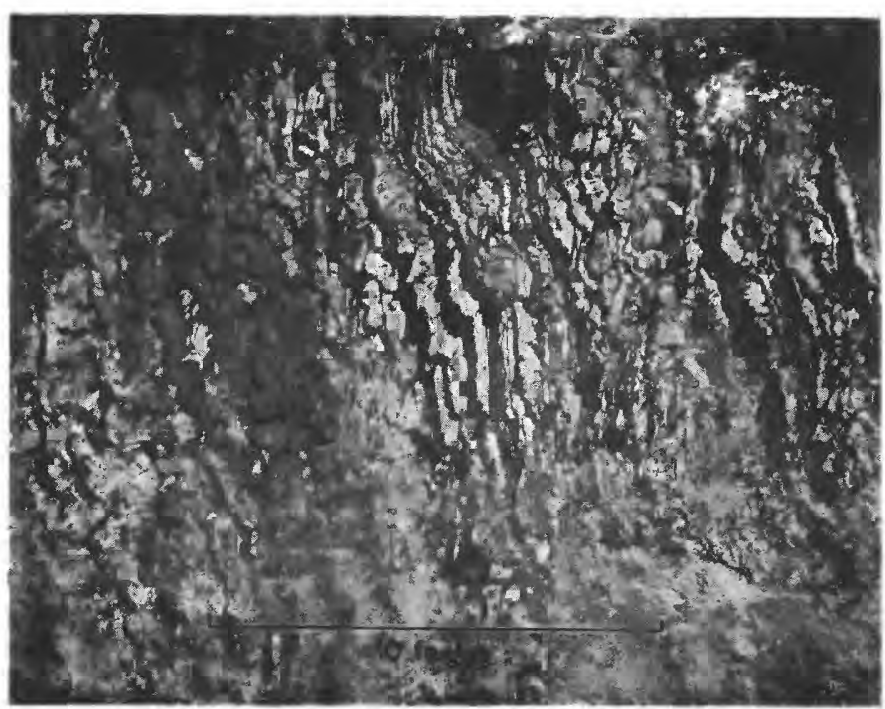

Figure 4.-Wash ore in wavy-bedded subfacies, thick-bedded Trommald formation, southwest end of Joan No. 1 mine. Viewer is facing vertical bank; stratigraphic top and axis of syncline are to the right. Light-gray areas are chert.

TABLE 5.-Chemical analysis of the channel sample 937 from the thick-bedded facies of the Trommald formation

[L. N. Tarrant, U.S. Geol. Survey, analyst]

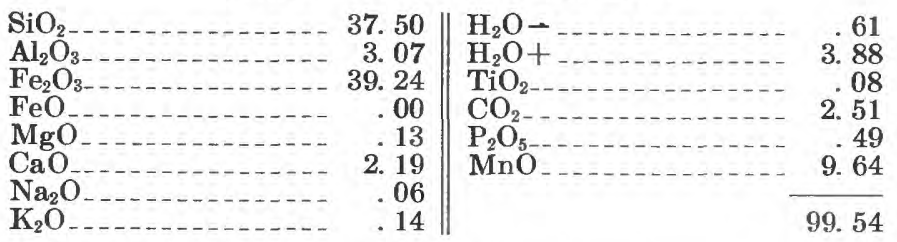

937. Thick-bedded iron-formation. Minerals are iron and manganese oxides and quartz. Channel sample about $10 \mathrm{ft}$ long cut perpendicular to bedding in Arko mine; coordinates: 360 S., 860 W. Collected August 1953. Lab. No. 54-71CD.

The wavy-bedded subfacies and the cherty layers of the straight-bedded subfacies contain "granular" textures, in which some of the minerals are segregated into minute elliptical or lenticular bodies surrounded by a matrix of slightly different or strongly contrasting mineralogic composition. Oolitic or concretionary granules with many distinct concentric layers were collected from a few places. Granules without concentric layering are much more abundant and are found in many places, but in most of the thick-bedded iron-formation no granules can be seen. The writer believes that they were generally present before folding and metamorphism, and thąt the widespread occurrence of mottled chert (fig. 5) and the small elongate lenticules that are seen in many places are the result of shearing and recrystallization that partly or completely destroyed the preexisting granular textures.

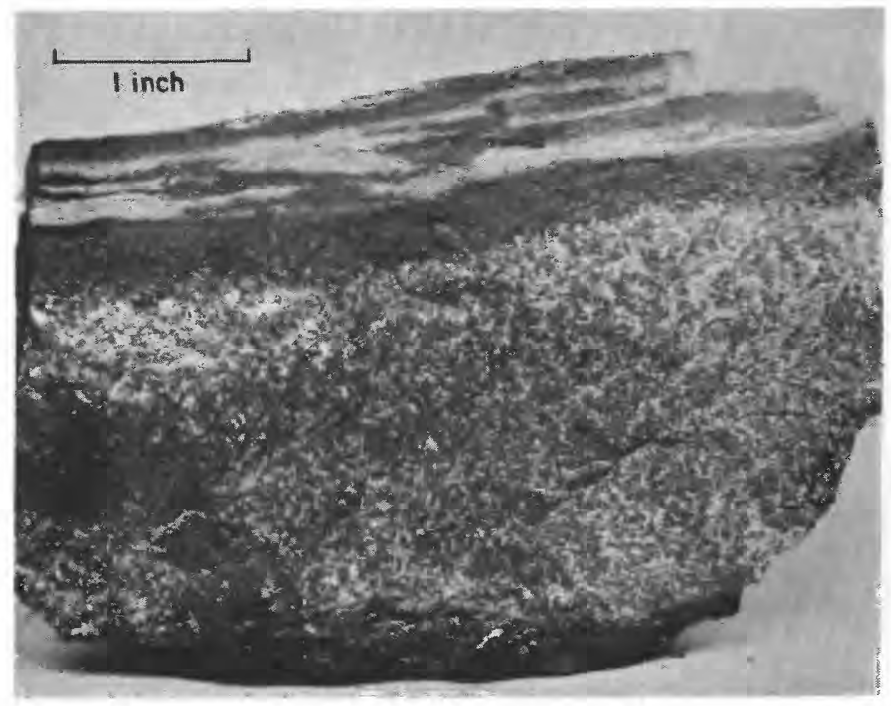

FIgURE 5.- Single bed of mottled chert, straight-bedded subfacies, thick-bedded Trommald formation, Joan No. 1 mine.

Some well-formed oolitic granules are composed of quartz that includes concentric layers of hematite dust. Other granules are various combinations of the minerals found in this facies: clear quartz granules in a matrix of quartz, carbonate, and fine iron silicates; mixed quartz, silicate, and magnetite granules in a matrix of solid magnetite or of magnetite, quartz, and hematite; quartz granules outlined by faint lines of magnetite and hematite in a quartz matrix; granules of clear quartz and quartz densely clouded by oxides faintly outlined by a matrix of intermediate cloudiness; granules of quartz and hematite in a matrix of magnetite and minor quartz; granules of quartz and ferristilpnomelane in a matrix of quartz, carbonate, and ferristilpnomelane; and rounded masses of carbonate in a matrix of carbonate, chlorite, quartz, and magnetite. One specimen of granular iron-formation from drilling near the Merritt mine, sec. 33, T. 47 N., R. 29 W. (pl. 3), contains numerous small sand grains of quartz, most or all of which formed nuclei for oolites.

\section{CLASTIC MATERIAL INCLUDED IN THE TROMMALD FORMATION}

SANDY LAYERS IN THE TROMMALD FORMATION

Clastic quartz sand is intermixed or intercalated in the Trommald formation at several places. Sandy layers as much as 1 inch thick near the bottom of the thin-bedded facies were exposed on the southeast 
side of the Joan mine in sec. 3 , T. 46 N., R. 29 W., and were observed in drill samples from beneath Menomin Lake north of that mine. Sandy layers were found in granular layers in a position of transition from the thin to the thick-bedded facies in the University of Minnesota drill hole, sec. 33, T. 47 N., R. $29 \mathrm{~W}$. (pl. 3). In the SE $1 / 4 \mathrm{SE} 1 / 4$ sec. 26 and NE1/4 NE1/4 sec. 35 , T. 47 N., R. 29 W. (pl. 2), abundant coarse sand occurs near the top of the thick-bedded facies. In the $\mathrm{N} 1 / 2$ sec. $22, \mathrm{~T} .47 \mathrm{~N}$., R. $29 \mathrm{~W}$. (pl. 2), abundant sandy layers are interlaminated near the base of the thin-bedded facies, and the bottom of the iron-formation at this place may pass gradationally into ferruginous silty argillite and quartzite at the top of the Mahnomen formation.

\section{ARGILLACEOUS LAYERS IN THE THIN-BEDDED FACIES}

In several places in the North range argillaceous layers are intercalated with the Trommald formation, and all of them are in the thin-bedded facies.

In the Sagamore mine where the Trommald formation is entirely thin-bedded, a layer of argillaceous rock ("paint rock") of varied thickness, but probably averaging 30 feet in thickness, is interbedded near the middle of the formation. At two places in the mine, textures in this intermediate argillite resemble layers near the base of the Rabbit Lake formation in other parts of the district. Some of the intermediate argillite contains 1.0 to 2.0 percent titania, as does the base of the Rabbit Lake formation. Beds in part of the intermediate argillite contain abundant tourmaline needles, which may locally comprise as much as 10 percent of the volume of the rock; these also occur locally near the base of the Trommald formation.

The writer believes that part of the intermediate argillite is reworked volcanic ash, that less titaniferous layers represent gradations to the relatively nontitaniferous enclosing iron-formations, and that the intermediate argillite is similar to the rocks in the titaniferous zone at the base of the Rabbit Lake formation described elsewhere.

In the Feigh, Mahnomen No. 3, Portsmouth, Manuel, and Rabbit Lake mines there are numerous small, generally concordant, layers of ferruginous slate and schist, some of them tourmaline rich (fig. 6), and less abundant breccia or conglomerate. The layers, nearly all titaniferous, are exposed in bands from about 1 to 20 feet thick and can be traced for 100 feet along the strike. The small size of exposures limited the tracing of these layers to their full extent; some exposures, however, were long enough to prove that the layers pinch and swell and probably disappear along the strike, and also that the abundance of breccia fragments and tourmaline crystals, where present, changes along the strike.

The layers of ferruginous slate or schist generally conform to the bedding of the iron-formation, but crosscutting of several inches of beds could be seen along a very few contacts, probably the result of channeling and subsequent filling by a water-borne sediment (fig. 7). The most common type of rock in these intercalated layers is a fine-grained slaty matrix containing scattered small iron-formation fragments, commonly chert fragments. The breccia fragments are generally sparse, constituting less than onetenth of the volume and only rarely exceeding half of the volume; the breccias grade into dense slaty rocks with no fragments. Where the enclosing iron-

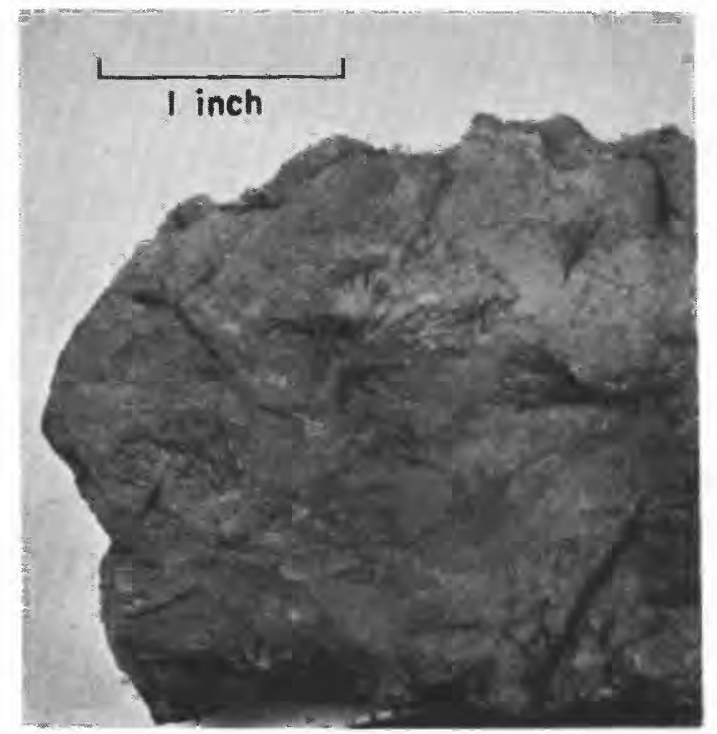

Frgdre 6.-Light-brown titaniferous ferruginous slate from lens in Trommald formation, with radiating sheaves of tourmaline crystals. Portsmouth mine, sec. 11, T. 46 N., R. 29 W.

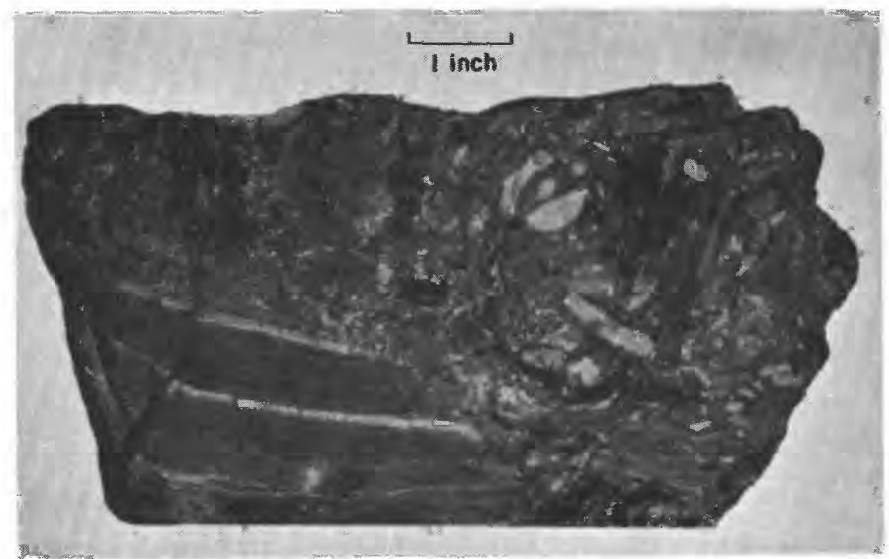

FIGURE 7-Thin-bedded magnetite-silicate iron-formation and crosscutting layer of iron-formation breccia with titaniferous matrix. The breccia is believed to be a channel filling. Portsmouth mine, 1953, drainage shaft, SW $1 / 4$ SE $1 / 4$ sec. 2 , T. 46 N., R. 29 W. 
formation is unoxidized, the matrix is hard and black and the fragments are gray, gray green, or black, depending upon the color of the iron-formation of which they are composed. The matrix, which is commonly titaniferous, contains minerals found in the iron-formation and presumably somewhat more argillaceous material, though this was not apparent in the single thin section examined. No titanium mineral was identified in this thin section, and the 2 percent $\mathrm{TiO}_{2}$ present only in the matrix is probably the abundant stilpnomelane or magnetite; in contrast, the adjacent iron-formation contains about 0.2 percent $\mathrm{TiO}_{2}$. Where the enclosing iron-formation is oxidized, the chert fragments are white, but the iron-rich fragments and also the matrix are red brown or brown. In many places this sort of rock is thoroughly softened by oxidation and leaching, and the white fragments, which may be partly clay rather than decomposed chert, are flattened and sheared into thin parallel plates.

The largest mass of titaniferous rock, presumably argillaceous, within the Trommald formation is in the Portsmouth mine in the NE $1 / 4 \mathrm{NW}^{1 / 4}$ sec. 11 . It is 40 to 60 feet wide and more than 500 feet long. The rock is gray schist that has slabs of iron-formation as much as 1 foot long near the contacts. The chemical composition (table 6, sample 1045) is most like some phases of the Rabbit Lake formation.

\section{RABBIT LAKE FORMATION}

The youngest of the three conformable sedimentary units in the Cuyuna North range is dominantly gray and black carbonaceous argillite and slate and intercalated lenses of lean siliceous argillaceous iron-formation; the name Rabbit Lake formation is here given to this unit. The formation is named from Rabbit Lake. The type area is designated as the area around Rabbit Lake. Tuffs and basalts that are believed to be flows are locally interlayered near the base. Slaty cleavage is developed in the rocks in many places. Along the southeast edge of the district, especially along the southeast edge of a group of mines from the Huntington to the Armour No. 1 ( $\mathrm{pl} .3$ ), a slightly higher degree of metamorphism formed chlorite and biotite schist.

There are many minor lithologic variations in the Rabbit Lake formation. Small lenses and thin beds of chert and ferruginous chert are found at many places. Alteration, the result of weathering and perhaps other processes, has caused pronounced color changes in the formation, especially from gray and black to light-gray green or red brown. In some places the argillite or slate has been altered, and part
TABLE 6.-Chemical analyses of seven samples of miscellaneous rocks from the Cuyuna district

\begin{tabular}{|c|c|c|c|c|c|c|c|}
\hline & 1199 & 1045 & 1043 & 1042 & 1044 & 156 & HJ -9 \\
\hline $\begin{array}{l}\mathrm{SiO}_{2} \\
\mathrm{Al}_{2} \mathrm{O}_{3} \\
\mathrm{Fe}_{2} \mathrm{O}_{3} \\
\mathrm{FeO} \\
\mathrm{MgO} \\
\mathrm{CaO} \\
\mathrm{Na}_{2} \mathrm{O}_{2} \\
\mathrm{~K}_{2} \mathrm{O}_{2} \\
\mathrm{H}_{2} \mathrm{O}- \\
\mathrm{H}_{2} \mathrm{O}+ \\
\mathrm{TiO}_{2} \\
\mathrm{CO}{ }_{2} \\
\mathrm{P}_{2} \mathrm{O}_{5} \\
\mathrm{MnO}\end{array}$ & $\begin{array}{r}48.92 \\
14.76 \\
2.54 \\
8.96 \\
6.78 \\
11.50 \\
1.52 \\
.53 \\
.11 \\
2.97 \\
1.27 \\
.02 \\
.16 \\
.18\end{array}$ & $\begin{array}{r}35.74 \\
14.68 \\
8.46 \\
18.61 \\
9.73 \\
.94 \\
.00 \\
.00 \\
.22 \\
8.48 \\
2.27 \\
.02 \\
.70 \\
.22\end{array}$ & $\begin{array}{r}72.48 \\
13.80 \\
3.26 \\
.80 \\
1.78 \\
.14 \\
.05 \\
3.98 \\
.47 \\
2.85 \\
.31 \\
.05 \\
.05 \\
.03\end{array}$ & $\begin{array}{r}57.83 \\
17.86 \\
3.12 \\
7.37 \\
3.15 \\
.45 \\
.08 \\
4.03 \\
.32 \\
4.63 \\
.58 \\
.02 \\
.32 \\
.03\end{array}$ & $\begin{array}{r}7.29 \\
4.22 \\
72.79 \\
1.13 \\
1.87 \\
4.30 \\
.00 \\
.06 \\
.74 \\
2.34 \\
.14 \\
.39 \\
3.70 \\
.89\end{array}$ & $\begin{array}{r}35.4 \\
1.5 \\
55.4 \\
.48 \\
.42 \\
.72 \\
.10 \\
.05 \\
\\
.05 \\
\\
.78 \\
1.2\end{array}$ & $\begin{array}{r}43.24 \\
1.12 \\
29.57 \\
17.09 \\
2.23 \\
1.56 \\
3 \\
3.88 \\
.04 \\
.40 \\
1.090 \\
1.45 \\
2.95\end{array}$ \\
\hline Total..... & 100.22 & 100.07 & 100.05 & 99.79 & 99.86 & 96.10 & 101.62 \\
\hline $\begin{array}{l}\text { Loss on } \\
\text { ignition } \\
\text { Boron }{ }^{3}\end{array}$ & & 10 & 50 & 60 & 100 & & 1.05 \\
\hline
\end{tabular}

1 Graphite.

2 Total manganese calculated as $\mathrm{Mn}_{2} \mathrm{O}_{3}$.

3 Analyses by P. R. Barnett, U.S. Geol. Survey.

Sample:

1199. Chloritized basalt conformably extruded or intruded in argillites, near base of Rabbit Lake formation. This was a grab sample of the least weathered basalt found in the fleld. Minerals were epidote, various 1,330 S., 1,670 E. Lab. No. C589. Faye H. Neuerburg, U.S. Geol. Survey, analyst.

1045. Chlorite schist, relationship to Trommald formation not known. Portsmouth mine; coordinates: 2,300-2,500 N., 50-300 W. Collected Septem-
ber 1953 . Lab. No. 54-78CD. L. N. Tarrant, U.S. Geol. Survey, analyst.

1043. Fine-grained micaceous siltstone. Grab sample of wallrock on north side Snowshoe mine, stratigraphically beneath ore body, presumed to be from the Mahnomen formation; coordinates: $10,000 \mathrm{~S} ., 10,450 \mathrm{~W}$. Collected Autumn 1953. Lab. No. 54-76CD. L. N. Tarrant, U.S. Geol. Survey, analyst.

1042. Gray argillite. Grab sample of wallrock on south side of Snowshoe mine, stratigraphically above ore boly; presumed to be from the Mahnomen formation; coordinates: 10,050 S., 10,350 W. Collected Autumn 1953. Lab. No. $54-75 \mathrm{CD}$. L. N. Tarrant, U.S. Geol. Survey, analyst.

1044. Hematitic ore. Grab sample from Snowshoe mine; coordinates: $9,700 \mathrm{~S}$. $10,000 \mathrm{~W}$. Collected September 1953. Lab. No. 54-77CD. L. N.' Tarrant, U.S. Geol. Survey, analyst.

156. Oxidized thin-bedded iron-formation from South range, Gorman mine, sec. 31, T. 131 N., R. 30 W., Morrison County, Minn. Grab sample, collected March 1952.

HJ-9. Unoxidized laminated silicate-magnetite iron-formation from south range, Adams mine, sec. 30, T, 46 N., R. 28 W. J. H. McCarthy, Reference: Harder and Johnston (1918, p. 120).

of or all the clay minerals were changed to alunite. Ferruginous argillite is abundant in many places; the iron is present as pyrite, iron oxide, and perhaps siderite. Chemical analyses of rocks from the Rabbit Lake formation are given in tables 2 and 7 . In table 7 it is shown that the potash content of the formation is high relative to the magnesia, lime, and soda. The basalt layers have been thoroughly chloritized and then, except in isolated blocks, weathered to a saprolitic material. The titania content is discussed below.

The tuffaceous rocks at the base of the Rabbit Lake formation contain about 2.0 percent titania (Schmidt, 1958b). The basaltic flows at the base contain 1.0 to 2.0 percent $\mathrm{TiO}_{2}$. The argillite and the more metamorphosed equivalent slate and schist contain from 1.5 to 3.7 percent $\mathrm{TiO}_{2}$ for about 300 feet from the base of the formation and between a trace and 1.5 percent in beds more than 300 feet from the base (fig. 8). 
TABLE 7.-Chemical analyses of eight samples of rocks in the Rabbit Lake formation

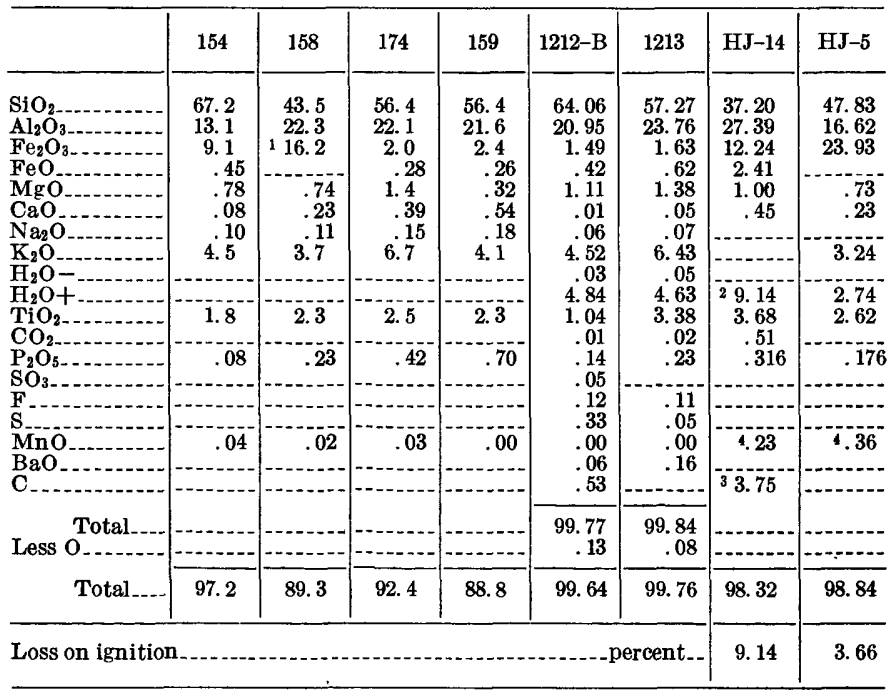

1 Presence of graphite made $\mathrm{FeO}$ determination not feasible.

2 Loss on ignition, essentially molecular $\mathrm{H}_{2} \mathrm{O}$.

3 Reported as graphite.

4 Total manganese calculated as $\mathrm{Mn}_{2} \mathrm{O}_{3}$

Sample:

154. Laminated slate. Grab sample, 0-30 ft from base of Rabbit Lake formation. Huntington mine; coordinates: 3,720 S., 1,780 W., alt, 1,133 ft. Collected June 1952. Lab. No. 52-1419CW. S. M. Berthold, U.S. Geol. Survey, analyst.

158. Black carbonaceous argillite. Grab sample, 0-20 ft from base of Rabbit Lake formation. Feigh mine; coordinates: 2,250 S., 1,300 E., alt, 1,030-1,100 ft. Collected June 1952. Lab. No. 52-1423CW. S. M. Berthold, U.S. Geol. Survey, analyst.

174. Gray laminated slate and tuffaceous slate. Grab sample, 0-20 ft from base of Rabbit Lake formation. Maroco mine; coordinates: 1,290 S., 2,550 E., alt, about 1,140 ft. Collected June 1952. Lab. No. 52$1428 \mathrm{CW}$.

159. Laminated slate and tuffaceous slate. Grab sample 0-20 ft from base of Rabbit Lake formation. Mangan No. 2 mine; coordinates: 3,620 N., 300 W., alt, 1,145 ft. Collected June 1952. Lab. No. 52-1424CW. S. M. Berthold, U.S. Geol. Survey, analyst.

1212-B. Dark gray laminated argillite. Grab sample about $5 \mathrm{ft}$ above base of Rabbit Lake formation. Joan No. 1 mme; coordinates: 1,910 N., $280 \mathrm{~W}$. Collected October 1954. Lab. No. C590. Faye H. Neuerburg, U.S. Geol. Survey, analyst.

1213. Gray tuff, fragment size about $1 \mathrm{~mm}$. Grab sample about $10 \mathrm{ft}$ above base of Rabbit Lake formation. Joan No. 1 mine; coordinates: 1,910 N., $280 \mathrm{~W}$. Collected October 1954. Lab. No. C591. Faye H. Neuerburg, U.S. Geol. Survey, analyst.

HJ-14. Black slate from drill hole north of Blackhoof Lake (vicinity of Huntington mine). J. H. McCarthy, School of Mines Experiment Station, University of Minnesota, analyst. Reference: Harder and Johnston (1918, p. 120).

HJ-5. Soft red laminated ferruginous slate from Rowe mine. Probably Rabbit Lake formation, near base. J. H. McCarthy, School of Mines Experiment Station, University of Minnesota, analyst. Reference: Harder and Johnston (1918, p. 120).

Minor amounts of silty and sandy rock, including quartzite, were found in the Rabbit Lake formation at a few places.

\section{BLACK ARGILLITE AND SLATE}

The gray and black argillite and slate of the Rabbit Lake formation make up perhaps 90 percent of the area of this unit at the bedrock surface and were well exposed in many mines, especially in the Armour
No. 2, Feigh, Huntington, and Mallen mines. The rock is varied from finely laminated to almost massive. The lamination is caused by variations in the clay mineral content imparting different grayness or different luster to the layers. The amount of iron is less than 1 percent to more than 20 percent and probably averages more than 10 percent. Part of and perhaps all the iron is unaltered argillite occurs as pyrite, though the mineral grains are ordinarily too small to be seen with the unaided eye. Part of the iron may be present as carbonate, but it was not observed. Where the black argillite is weathered, the iron is an oxide.

Alunite was identified in black argillite in the Rabbit Lake formation from the Armour No. 2, Pennington, Maroco, and Virginia mines. It is present in various amounts and is most abundant in specimens from the Armour No. 2 mine, in which it is half of to nearly all the particular specimens examined. No alunite was detected in some samples from the Virginia mine nor in samples from the Mallen, Manuel, Section Six, Feigh, and Joan mines, though all were materials from the Rabbit Lake formation and closely resembled the alunitic rocks. No widespread sampling to determine the extent of the alunitic rock was attempted.

The alunite was recognized in the pattern obtained from the X-ray diffractometer and confirmed in several specimens by a simple chemical test (Butler and Gale, 1912 , p. 63) and by examination of thin sections. The alunitic black argillite cannot be distinguished from ordinary black argillite by field examination, and there is no outward evidence of hydrothermal or surficial alteration. The alunite occurs as a mosaic of fine crystalline grains that make up most of or all certain laminae and all the small granules that are abundant in certain beds. In the specimen containing most alunite, nearly all the rock is a finegrained aggregate of this mineral. Bedding lamination and granule ontlines are made readily visible by the distribution of fine interstitial carbon particles. Quartz and calcite are present in minor amounts.

The origin of the alunite is not known; but perhaps pyrite, abundant in parts of the Rabbit Lake formation, was oxidized and released sulfuric acid that reacted with muscovite and produced alunite. The sedimentary rocks near the bottom of the Rabbit Lake formation generally contain 3.2 to 6.7 percent potash. There are few data on the sulfur content of rocks of this type. A laminated tuffaceous argillite from the Joan mine (table 7, sample 1212-B) contains 0.05 percent $\mathrm{SO}_{3}$ and 0.33 percent sulfur. The rock was not tested for alunite. 


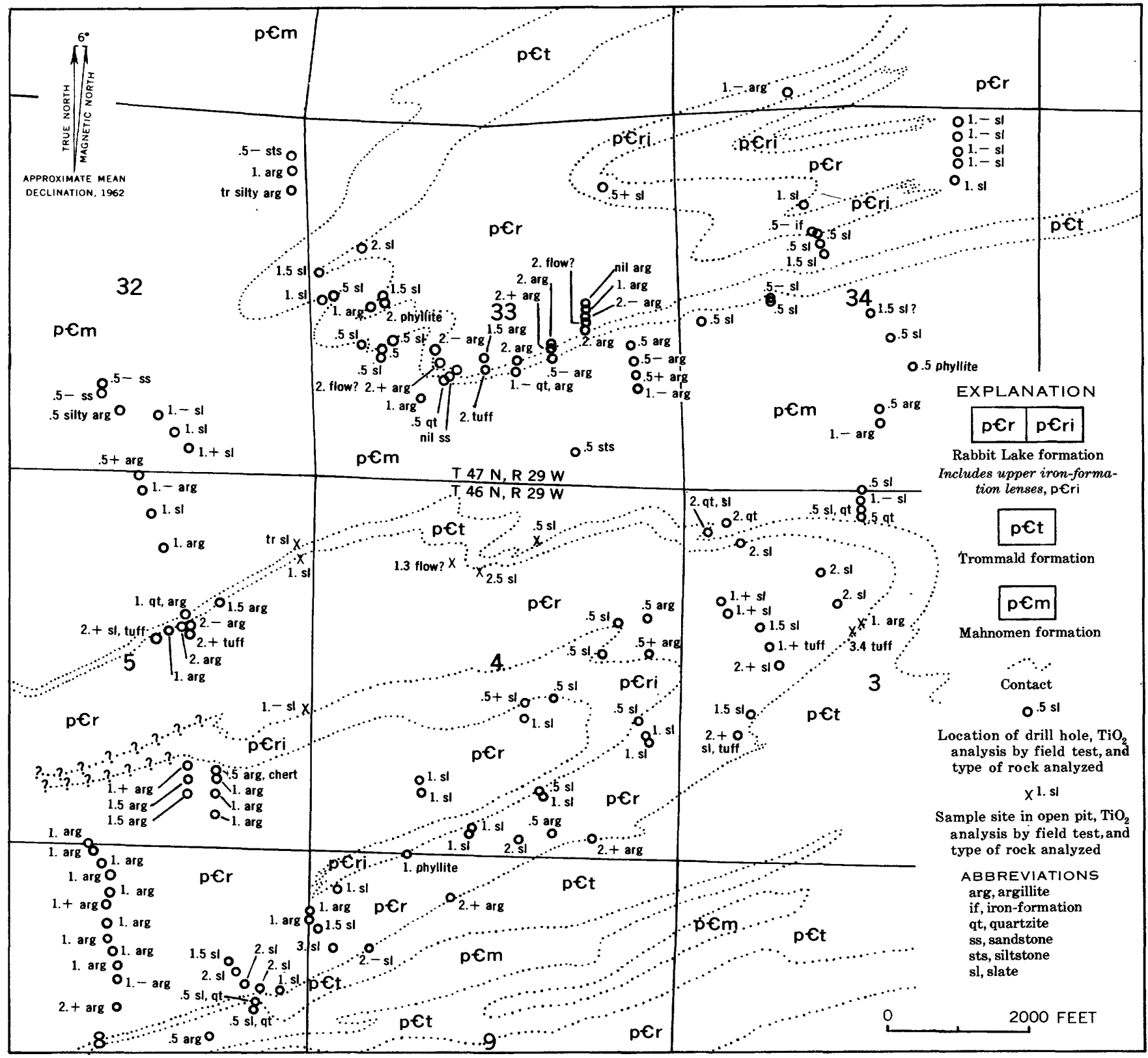

Figure 8. - Titania content of the Precambrian rocks in a part of the North range, Cuyuna district, Minnesota. Adapted from Schmidt $(1958 \mathrm{~b})$.

\section{UPPER IRON-FORMATION LENSES}

Iron-formation lenses interbedded in the Rabbit Lake formation are locally abundant. They occur as thin units of local extent and as large masses several hundred feet thick that continue for several miles. The iron-formation lenses differ from the Trommald formation by having transitional contacts and being generally very siliceous and containing abundant interbedded argillite or slate. The only exposures were in the now idle Virginia mine.

The iron-formation lenses occur from about 500 feet above the base of the Rabbit Lake formation to
2,000 feet, as far as the formation has been explored; only a very few unmappable lenses of ferruginous chert less than 10 feet thick have been found in the lower 500 feet of the formation.

The lens of upper iron-formation that passes through the Virginia mine is as much as 200 or 300 feet thick, and it occurs in an area about 2 miles long. Inclusions of abundant argillaceous material render this iron-formation very incompetent, and it tends to be folded in a most intricate fashion; therefore, estimates of true thickness from drilling data are only rough approximations. The intricate folding was well ex- 
posed in the southwest end of the now flooded Virginia mine (fig. 9). Between sec. 27, T. 47 N., R. 29 W., and Rabbit Lake as much as half of the area of Rabbit Lake formation exposed at the bedrock surface may contain 20 percent or more iron and would be mapped as iron-formation if enough information was available; in addition, much of the argillite is ferruginous. Designation of the marginal contacts of the iron-formation by either examination of drill samples or an arbitrary cutoff based on iron analyses is very difficult.

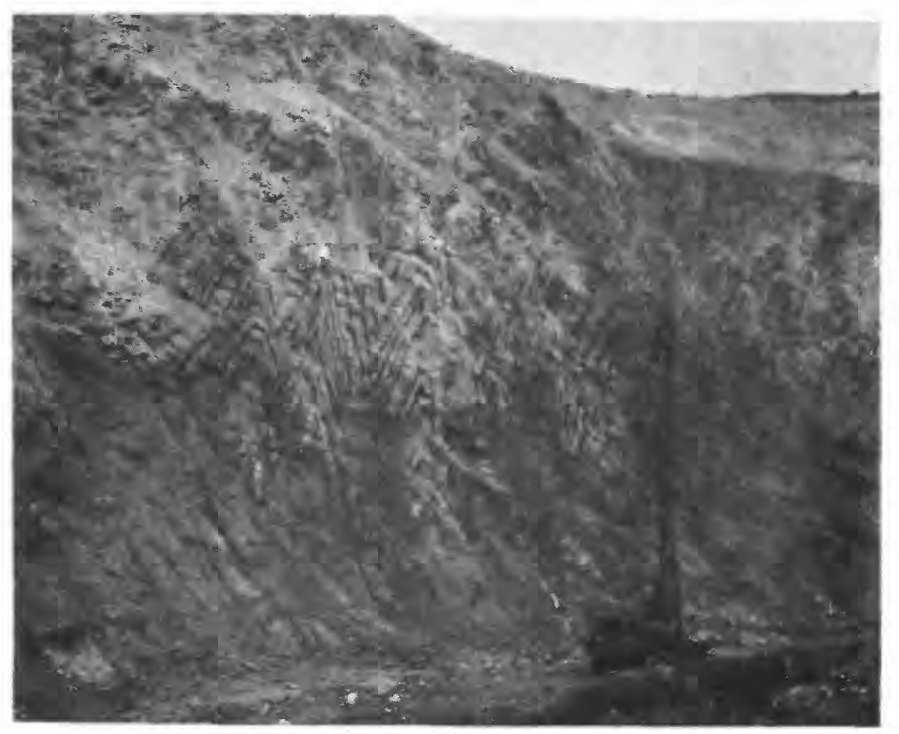

Figure 9.-View in Virginia mine looking southwest and showing intricate folding in argillaceous siliceous upper tron-formation interbedded in the Rabbit Lake formation. Churn drill is about 35 feet high.

Unmapped lenses of fermuginous chert are present within 100 feet of the base of the Rabbit Lake formation at a very few places: lenses of chert several inches thick were found on the southeast side of the Feigh mine, and a lense of laminated ferruginous chert was observed in the Maroco mine.

Where the upper iron-formation is locally less argillaceous and less siliceous, it closely resembles the thinbedded facies of the Trommald formation. In contrast with the Trommald formation, however, the conditions favorable for deposition of the upper ironformation must have prevailed over smaller areas; the favorable periods began and ended gradually rather than abruptly, and organic remains and clay were deposited more abundantly with the iron minerals and silica.

Unlike the iron-formation of the Trommald formation, little of the iron-formation within the Rabbit Lake formation was found that could be considered unoxidized or unaltered. Finely divided pyrite was found in a few specimens. Siderite probably was an important primary mineral. The presence of abundant organic matter and the absence of magnetic attraction make it improbable that magnetite was originally abundant. Red and brown oxides are the iron minerals now seen.

The upper iron-formation lenses are relatively unproductive. Approximately 0.7 percent of the total iron-ore production plus known reserves in the North range can be attributed to this unit.

\section{THICKNESS OF FORMATION}

The original thickness of the Rabbit Lake formation is not known because it is the youngest Precambrian sedimentary unit on the North range. The youngest beds are believed to be near the center of sec. 26 and in the NW $1 / 4$ sec. 25, T. 47 N., R. 29 W. This location is near the center of a large doubly plunging, somewhat asymmetric, syncline, and the youngest beds are presumed to occur slightly to the southeast of the geographic center of the structure, nearer the steep overturned flank of the fold. Several drill holes penetrate the formation in the $N W 1 / 4$ sec. 25 , and the drill samples are gray, black, and brown argillite and lean oxidized iron-formation. If one judges from the size and shape of the fold and allows generously for increase in the apparent thickness of beds by drag folding, the youngest beds are 2,000 feet above the base of the formation. Although the large syncline that plunges southwestward from Menomin Lake is equally wide where crossed by the Mississippi River (pl. 2), the limbs are probably more gently inclined, and the beds exposed in the center are probably not so far above the base of the formation as those in the area west of Rabbit Lake.

\section{CHLORITE AND CHLORTTW-BIOTITE SCHISTS}

Conspicuous gray-green schists containing sedimentary bedding are exposed along the southeast edge of the district in the southeast banks of the South Hillcrest, Feigh, and Pennington mines, and in underground workings of the Armour mines. Unbedded schists occur on the southeast sides of the Sagamore No. 2 and Huntington mines. The schistosity and the abundance of chlorite and biotite indicate a higher metamorphic grade than in sedimentary rocks elsewhere in the district, but the difference in grade is small, the changes being mainly the formation of biotite and large better oriented flakes of chlorite and crystals of apatite.

Bedded gray-green schist conformably overlies gently folded Trommald formation (fig. 10) in the southwestern part of the Feigh mine and along the south side of the Pennington mine. Axial-plane cleav- 
age in the schist and iron-formation is nearly vertical and indicates that the structures and the stratigraphic sequence are not overturned and that the schist is the stratigraphic equivalent of the lower beds of the Rabbit Lake formation. The difference in color and general appearance is striking but is largely due to the growth of the oriented micaceous minerals and disappearance of the black carbon. Examination of thin sections shows the sedimentary textures to be about the same as in less metamorphosed Rabbit Lake formation. The schists contain 8 to 13 percent iron and 1.5 to 2.2 percent titania, similar to the argillaceous phase of the basal Rabbit Lake formation. Pyrite in the schist occurs as well-formed cubes as large as 1 inch across.

No place has been found where the schists grade laterally into the gray and black laminated argillites that are typical of the base of the Rabbit Lake formation. Black slate is in core from a drill hole at the Sagamore No. 2 mine about 300 feet along the strike from exposed gray schist:

\section{CONDITIONS OF SEDIMENTATION IN THE CUYUNA DISTRICT}

The three sedimentary formations of the Cuyuna district were probably deposited in a slowly deepen- ing geosyncline. Deposition began with well-sorted clastic material without iron and without organic matter characteristic of a "stable shelf," and the last sediments of which we have record were fine muds containing abundant organic matter and iron typical of a deep basin with poor circulation. Basaltic volcanic rocks accompanied the last depositional phase. This sequence of environments corresponds closely to the diagrammatic outline of the history of an iron-formation geosyncline proposed by James (1954).

\section{MAHNOMEN FORMATTON}

The base of the Mahnomen formation has not been observed, and it can only be surmised that it rests upon a crystalline complex of granite, gneiss, schist, and slate- the types of older rocks known to occur around the basin.

During the time of deposition of the Mahnomen formation, generally well-sorted iron-poor silts and clays were deposited in all parts of the North range. Numerous thin beds of limestone probably formed locally, but they were observed only in core from one drill hole near the Northland mine. A small amount of black carbonaceous material was incorporated as thin laminations in only two places-a small area in the Mahnomen No. 1 mine and in one drill hole in sec. 5 , T. 46 N., R. 29 W.

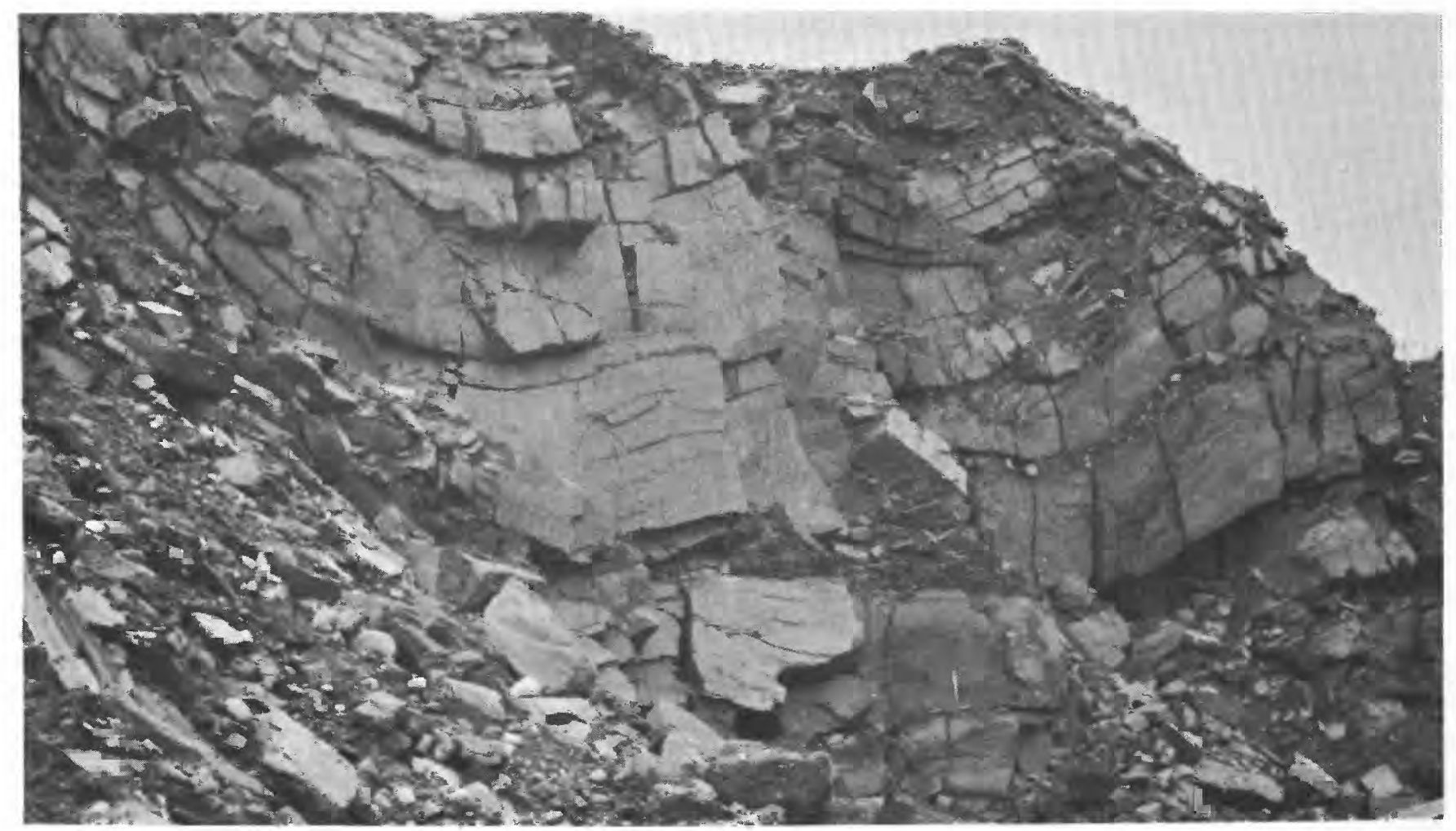

Figure 10.-Bedded biotite-chlorite schist at the base of the Rabbit Lake formation in open folds on the south side of the Pennington mine, looking west. The folds plunge gently southwest. The handle of the hammer near the bottom of the bedrock exposure is 1 foot long. 
Near the end of Mahnomen deposition, lenses of sand became abundant, especially in the central and southwestern parts of the North range. This perhaps indicates that the water was shallower in that area. Local disturbance of the muds, perhaps by storm waves, is suggested by the inclusion of abundant clay flakes in some of the sand lenses.

\section{TROMMALD FORMATION}

The Trommald formation is a chemically precipitated unit generally free of clastic material and representing, in various parts of the North range, the oxide, carbonate, and silicate facies of iron-formation.

The change from the clastic sedimentation of the Mahnomen formation to the chemical sedimentation of the Trommald was abrupt at all places where the contact relations are definitely known. There is no evidence that this contact transcends beds of equal age, but it is possible that the contact represents an onlap of considerable importance that is related to the variations in thickness of the iron-formation.

The thick-bedded (oxide) facies of the Trommald formation covered about one-third of the area of the North range at the beginning of deposition but spread as the Trommald formation accumulated until its extent had doubled by the end of deposition. The thickbedded facies, which was probably composed of hematite, chert, and iron silicates, was deposited upon the Mahnomen formation in the west-central part of the North range, more or less corresponding to the area of underlying thicker quartzite lenses (pl. 5). Where only the thick-bedded facies is present, the iron-formation is thinner, and it is possible that the Trommald formation wedges out entirely if traced westward from the North range. The formation is thickest where only the thin-bedded chert-carbonate-siderite-magnetite facies was deposited. Near the gradually shifting interface between the facies was a zone of manganese deposition. Presumably this zone was shifting seaward as accumulation of sediments lessened the depth of the water.

It is known that the two facies were deposited simultaneously during part of the time required for the whole formation to be precipitated because they grade laterally into each other. Where the Trommald formation is entirely thick bedded, the total number of beds is far smaller than in a similar total thickness of thin-bedded facies; and deposition of one thick bed took place during the same time as many thin beds. Thus, the changes in the sedimentary environment causing alternating thick beds of chert-rich and iron oxide-rich rock did not produce any gross cyclic variations in the bedding of the thin-bedded facies. This suggests that the alternation of constituents was caused by local conditions in the depositional basin, not by changes in the material supplied to the basin.

\section{SOURCE OF IRON-RICH SEDIMENTS AND CONDITIONS OF SEDIMENTATION}

The origin of Precambrian iron-formation has been one of the most puzzling problems in Precambrian geology. There is general agreement on many features and wide disagreement on others; Guild (1957) described the problem as follows:

Chert and cherty iron formation have been widely discussed for generations by geologists of many countries, for these rocks have worldwide distribution in the pre-Cambrian and occur sparingly in the younger systems as well. The problem of their origin resolves itself into several parts: (1) the source of the vast quantities of iron and silica; (2) the mode of transportation; (3) conditions which permitted their selective concentration and the exclusion of other materials; and (4) the rhythmic layering of the formations.

There is now general agreement that iron formations are chemical precipitates of iron compounds, silica, and carbonates, containing minor amounts of alumina, manganese, phosphorus and other constituents.

The source of the iron and silica is a problem that is still argued. Winchell first suggested that the ferruginous sediments were derived from volcanic ash (Winchell, 1900). Van Hise and Leith (1911) elaborated on the "volcanic theory":

The close association of iron-bearing sediments with contemporaneous basic eruptive rocks in the Lake Superior region and in other parts of the world, the richness of these eruptive rocks in iron salts, and the probable derivation of the upper Huronian slates associated with the iron-bearing formations from the eruptions make it a plausible hypothesis that these iron-rich eruptive rocks were the principal source of the iron in the iron-bearing sediments. As to the manner in which the iron was transferred from the eruptive rocks to the place of sedimentation, there are several possible hypotheses. (1) It may have been transferred in hot solutions migrating from the eruptive material during its solidification, carrying iron salts from the interior of the magma which had never been crystallized; (2) so far as the lavas were subaerially extruded, iron may have been transferred by the action of meteoric waters working upon the crystallized iron minerals in the magma, either hot or cold; (3) the iron may have been transferred by direct reaction of the hot magma with sea water, in which the iron-bearing sediments were deposited.

The volcanic theory has been accepted by many geologists: Collins, Quirke, and Thomson (1926); Wagner (1928); Aldrich (1929); Percival (1931); Dunn (1935, 1937); and Goodwin (1956). It was opposed by Gruner (1922) who showed that chemical weathering of a land area was capable of supplying enough iron and silica. He calculated that the Amazon River now carries enough iron, 3 ppm (parts per 
million), to deposit the Biwabik iron-formation of the Mesabi district in 176,000 years. James (1954) stated:

There is much evidence opposed to the volcanic theory. The correlation between volcanism and iron-formation during the Huronian of the Lake Superior region, stressed by Van Hise and Leith, is not close. In most of the ranges, no volcanic activity is indicated during the major iron-formation epochs.

White (1954) concluded that:

Moreover, there is some reason to believe that vulcanism contemporaneous with Animikie sedimentation was detrimental rather than conducive to iron concentration.

Geologists continue to argue the problem of the origin of the iron and silica, but the problem remains unsolved at this time. Gruner wrote (1956, p. 199), "In 30 years we do not seem to have been able to add a single field observation pro or con that bears on the two hypotheses."

The transportation of the iron and silica is probably not a difficult problem, for they can be carried in rivers as stabilized colloids or in true solutions (Moore and Maynard, 1929; Castano and Garrels, 1950 ; Krauskopf, 1956). It is most generally believed that the iron was transported as a ferric oxide-hydrosol stabilized by organic colloids. If the iron was carried as a ferric oxide-hydrosol derived from an area of deeply weathered rocks, it would seem that it would have been accompanied invariably by clay. "Clastic traps" have been suggested by many authors, but it is not clear how these effectively trapped one colloidal substance and permitted the other to be carried on. Final precipitation of the colloids was easily accomplished by the electrolytes in marine waters or by the destruction of a protective organic colloid by bacteria.

The Precambrian iron-formations were deposited in geosynclinal basins that were as much as several hundred miles in length. The water of these basins was probably more acid than modern sea water (a pH of 7.8 or below, the "limestone fence" of Krumbein and Garrels, 1952), but the composition of the open sea in Animikie time is not known. Several authors have assumed that the iron-formations were deposited in lakes or lagoons practically separated from the open sea: Sakamoto (1950) and Tyler and Twenhofel (1952). A more popular concept at this time is deposition in basins separated from the open sea by a "circulation barrier": Woolnough (1941), James (1954), Goodwin (1956), and Guild (1953, 1957). White (1954, p. 51) was not-

certain that a restricted (barred) basin was a prerequisite for the concentration of iron. Circulation of water was probably slow, and the site of deposition may at times have had limited access to the open sea; yet no evidence at hand rules out a shallow, relatively tideless epicontinental sea as a possible medium of deposition.

James (1954) has suggested a relation between the deposition of iron-formation and the development of a geosyncline. The Precambrian iron-formations in many areas rest on sedimentary rocks characteristic of shallow shelf deposits and are overlain by strata characteristic of the graywacke facies generally deposited in eugeosynclines. James considered that this geosynclinal environment accounted for the association of iron-formation and basaltic volcanic rocks in many districts and he stated:

On the basis of the evidence outlined, the conclusion is drawn that the relationship between volcanism and ironformation deposition is structural, not chemical. In a sense, the association is accidental; both are related to the geosynclinal development.

The writer feels that the necessity of physical separation from the open sea has been overemphasized and that an environment of very different oxidizing potential and acidity can probably be maintained in extensive shallow water with practically no barrier separating it from the open sea. This idea is borne out by the work of Black (1933), who described conditions in the Bahama Banks where warming and evaporation of the water have produced a considerable change in the $\mathrm{pH}$ and salinity over the extensive shoal area, which is protected from the open sea by a barrier on only part of one side.

Twenhofel (1932) grouped the iron-bearing sedimentary rocks into four classes-oxides and hydroxides, carbonates, silicates, and sulfides; James (1954) described these same classes as sedimentary facies of iron-formation formed under specific conditions of acidity, oxygen availability, and abundance of alumina within the same depositional basin.

The rhythmic banding present in all iron-formations has been variously explained. Moore and Maynard (1929) wrote that:

The banding in the deposits, as shown by experiment, could be due to the differential rate of precipitation of the iron and silica combined with the influence of seasonal changes causing varying quantities of these substances to be brought into the basin of deposition at different periods throughout the year.

Sakamoto (1950) thought that the banding might be due to seasonal changes in $\mathrm{pH}$ in the nonmarine depositional basin as a result of a monsoonlike climate. Guild (1953) suggested that fluctuations, perhaps annual, in the volume of water added to the basin would produce alternations of iron-rich and silica-rich layers.

Goodwin (1956) considered that volcanism "induced cyclical fluctuations in the basin of deposition. The result was cyclic deposition of iron and silica-bearing sediments." 


\section{Alexandrov (1955) suggested the-}

banding of silica and hematite in Precambrian banded ores is caused principally by the selective weathering of Precambrian soil. Due to the seasonal changes of temperature, amount of precipitation, and the alternately higher and lower $\mathrm{pH}$ range of the leaching solution, the Precambrian soil yielded alternately solutions carrying to the basin of deposition almost exclusively silica during the warm season and chiefly iron oxide during the cool period of the year.

More information will be needed before better understanding of the banding of iron-formation may be reached.

Most of the Trommald formation contains only small amounts of argillaceous material and, except in a few places, is free of clastic quartz sand. The alumina content generally ranges from less than 1 percent to 5 percent, and a few samples contain as much as 9 percent. Because the deposition of finely laminated iron-formation was probably relatively slow, it is assumed that the paucity of clastic material indicates that little was carried into the depositional basin or that distribution within the basin was limited. Within the Trommald formation at the Sagamore mine there is a thin persistent layer of ferruginous argillite that may have been a local layer of volcanic ash. Thin intercalated chert breccias and ferruginous slates and schists in the Portsmouth and several nearby mines may also have been related to ash falls.

The thick-bedded facies of the Trommald formation probably wholly or partly represents the oxide facies as defined by James (1954), and the thin-bedded facies includes both the carbonate and the silicate facies. The thick-bedded facies is in that part of the district where quartzite is most abundant in the underlying Mahnomen formation. Where both thick- and thinbedded facies occur together, the thick-bedded always overlies the thin-bedded. The writer infers from these features that the thick-bedded iron-formation was only deposited on the shallowest part of the bottom, but, as the bottom was built up by the accumulation of iron-formation and the area with sufficiently shallow depth increased, the thick-bedded facies was laid down on top of the thin-bedded in an ever-widening area. The inference regarding the relative depth of water is consistent with the relative positions of the mineral facies present (James, 1954, p. 242).

Field evidence in the Cuyuna district sheds little new light on the complex problem of the origin of the iron-formation. The field data are insufficient for a reconstruction of the history of deposition so complete as was possible in the Mesabi district (White, 1954); however, the data available fit easily into, and tend to corroborate, the general outline of depositional history of a typical iron-formation basin (James, 1954).
Final conclusions regarding the local relation of ironformation deposition and volcanism in the Cuyuna district may be drawn when the origin of the basalts and of the rocks believed to be tuffs is more definitely established.

\section{RABBIT LAKE FORMATION}

The conditions of deposition of the Trommald formation were terminated by the abrupt influx of abundant argillaceous and probably local volcanic material into a deepening basin. As the Rabbit Lake formation accumulated, deposition of iron continued, perhaps at the same rate as during Trommald time; but dilution by clays and silts generally prevented the formation of iron-formation, except for the discontinuous lenses of lean argillaceous upper iron-formation intercalated in many places, and stagnation of the bottom waters caused simultaneous deposition of abundant black carbon and a change to deposition of pyrite and probably siderite.

A brief study of the titania content of the sedimentary and volcanic rocks of the Cuyuna North range was made to determine the source of the argillaceous material included in the Trommald formation, and it was concluded that the clays were derived from weathering of basaltic rocks on a landmass, or more likely, from local decomposition of basaltic tuffs. The amount of titania in all the "normal" sedimentary rocks was found to be remarkably proportional to the amount of alumina (fig. 11), whereas near the base of the Rabbit Lake formation the amount of titania is generally about four times greater, but the ratio to alumina is not entirely so uniform. Higher and more erratic proportions of titania relative to alumina were also noted in argillaceous layers within the Trommald formation at the Sagamore, Portsmouth, and other mines. This feature suggests not only the continuity of a source of argillaceous materials during Mahnomen and Trommald time, but also that there were brief periods during Trommald time when minor amounts of volcanic ash were deposited in the basin.

The deposition of the Rabbit Lake formation began abruptly with the addition of abundant volcanic rocks, especially tuffs, to the basin. This was probably accompanied by deepening of the basin; in any case, a change in conditions in the basin to greater stagnation permitted preservation of abundant organic carbon. Deposition of iron continued, but the minerals were pyrite and perhaps siderite. As mentioned on page 32 , White (1954) has related the termination of deposition of the Biwabik formation to the addition of the volcanic materials of the Virginia formation to the depositional basin. The writer believes that volcanism, probably accompanied by diastrophic 


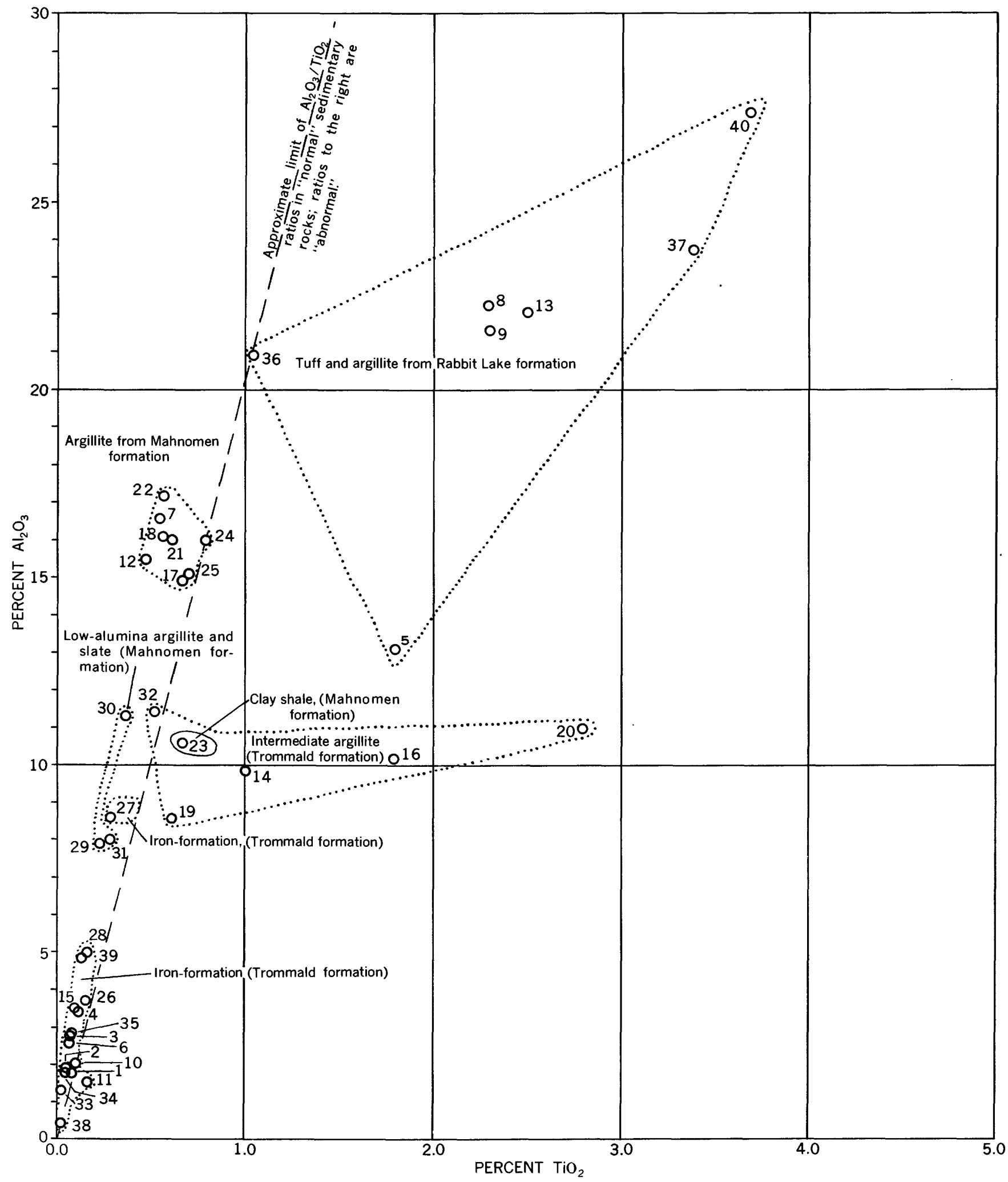

Figure 11.-Alumina-titania ratios in 40 samples of iron-formation and associated rocks, Cuyuna district, Minnesota. 
changes affecting the shape or depth of the basin and the rate of influx of clastic materials into the basin, caused the remarkably sharp contact between the Trommald and Rabbit Lake formations. Diastrophic changes were not radical enough to produce the conglomerates and quartzites shown by James (1954, p. 278 ) in a deepened basin formed after deposition of the iron-formation.

\section{CORRELATION OF THE CUYUNA SEQUENCE}

The determination of proper age relationships of Cuyuna district strata, both within the district and relative to other areas, especially the Emily and Mesabi districts, has interested many geologists. Several problems still remain unsolved because the work is made difficult by the lack of natural exposures, saprolitization of part of the uppermost bedrock, complex folding, and, to some extent, metamorphism.

\section{COMPARISON OF THE PROPOSFD STRATIGRAPHIC SECTION AND OTHERS FORMERLY DESCRIBED}

\section{NORTH RANGE}

Field and laboratory study of the Cuyuna district in this investigation has shown that nearly all the ores occur in one well-defined stratigraphic unit, the Trommald formation. This formation, because of its economic importance, has been traced almost continuously by exploratory drilling and magnetic surveys throughout the area mapped in this study. Within this area, the lithologic characteristics of the Trommald formation and, to a lesser extent, of the Mahnomen and Rabbit Lake formations, differ considerably from place to place. Study of the geology exposed in mine pits and inferred from examination of many drill samples has shown that the variations are transitional and reflect differences in the original depositional environment. One example of transition is the gradual disappearance of quartzite lenses at the top of the Mahnomen formation toward the east. Gradation in the Trommald formation is from an exclusively thick-bedded facies, which is less than 45 feet to at least 120 feet thick, into a thick-bedded facies overlapping a thin-bedded facies, which are together 100 to 400 feet thick, and finally into an entirely thin-bedded facies, which is about 200 to more than 500 feet thick (pl. 5).

In the Rabbit Lake formation, volcanic rocks are more abundant in the western part of the district, perhaps more abundant in the near vicinity of the Maroco mine; the upper iron-formation (in the Rabbit Lake formation) is more abundant in the northern part of the district, particularly in the large syncline extending from the Merritt mine to the east end of Rabbit Lake.

Little attempt has been made by previous writers, except Wolff (1951) and Grout and Wolff (1955), to prepare a comprehensive geologic map of the North range. Comparison of Wolff's map with the maps prepared in this study show very great differences in the interpretations of large structural features and district stratigraphy. The main features in the interpretation by Wolff are large faults made necessary by his stratigraphic interpretation. Wolff's stratigraphic column differs from that presented here by assuming that each unique combination of lithologic types found in the mines represents a different part of a complicated stratigraphic sequence of great thickness $(2,575$ to $3,465 \mathrm{ft}$ of iron-formation plus more than $350 \mathrm{ft}$

DESCRIPTION OF SAMPLES FOR FIGURE 11

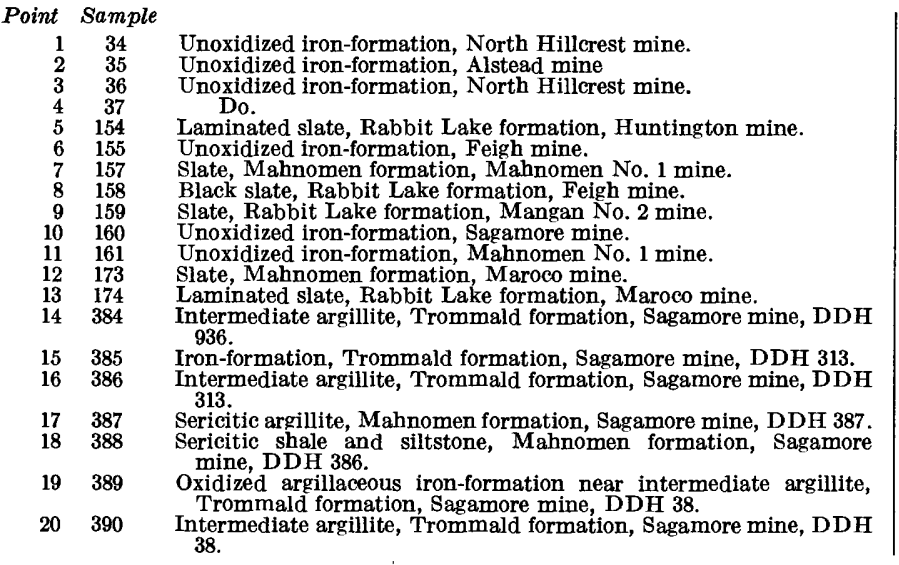

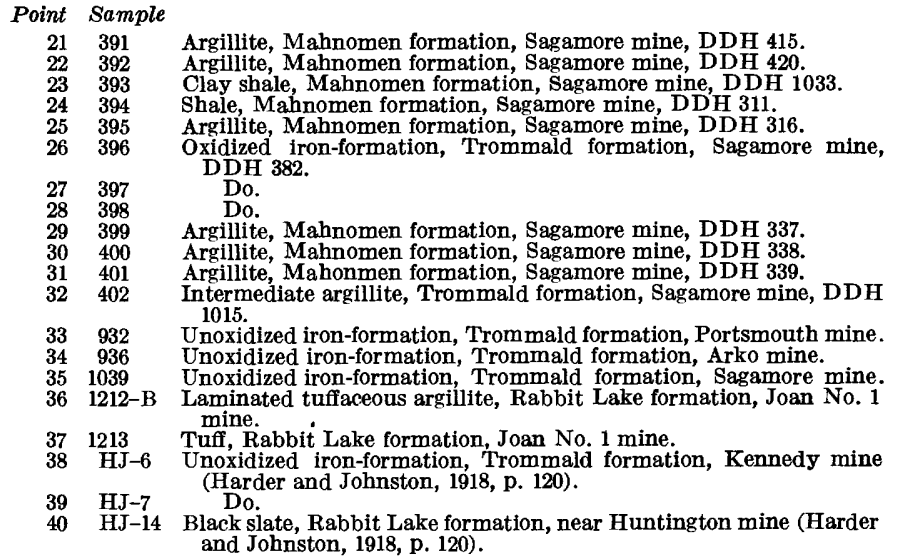


of Pokegama formation plus $5,000 \mathrm{ft}$ of Virginia formation), each part of which is inferred to be correlative with a specific part of the Mesabi succession. In contrast, the succession presented here involves one main iron-formation averaging about 200 feet in thickness, and perhaps 2,000 feet of sedimentary rocks below and 2,000 feet of sedimentary and minor volcanic rocks above it, aggregating a total section of about 4,500 feet, only a small part of which is iron-formation.

The writer believes that Wolff's different interpretation of the stratigraphy is directly related to his interpretation of relatively abrupt facies changes that take place in the iron-formation. Wolff has explained each facies change of the iron-formation as indicative of slightly different ages of strata, and adjacent occurrences of different facies were separated by inferred faults of great throw. If the faults do not exist, Wolff's detailed stratigraphy is untenable.

On Wolff's map (1951; Grout and Wolff, 1955) a major fault is shown extending from the Sagamore mine to the northeast end of Menomin (Mahnomen) Lake. This fault separates belts of "Lower Cherty" iron-formation and large areas underlain by Pokegama formation and "Lower Slaty" iron-formation on the northwest side from "Upper Slaty" and "Upper Cherty" iron-formation on the southeast side. Examination of drill-hole records and especially the cores and cuttings provides, however, a much different interpretation for the lithologic character of the bedrock.

At the Sagamore No. 2 mine (pl. 4), quartzite comprises a conspicuous part, perhaps half, of the exposure of "Pokegama" formation on the northwest bank. Outside the mine, quartzite is a minor rock type in a large thoroughly drilled area in the northwestern part of sec. 19 and south of the Rowe mine in sec. 18. The area is underlain by argillite and siltstone and some shale and slate; quartzite is limited to a small area near the mine. The rock penetrated by the drill holes that go through the iron-formation at the northeast end of the Sagamore No. 1 mine and by the holes east of the mapped fault, both north and east of the mine, is mostly argillite, slate, and siltstone.

The iron-formation extends northeastward in a straight distinctly continuous belt from the Rowe mine in sec. 18 to the Mallen mine in sec. 17, T. 46 N., R. $29 \mathrm{~W}$. (pl. 4). It is stratigraphically underlain on the south side by light-gray and red-brown slate and siltstone and minor quartzite at the Rowe mine and by light-gray and red-brown slate and siltstone at the Mallen mine. The iron-formation is stratigraphically succeeded on the north side by red-brown and gray to black tuffaceous and titaniferous argillite and slate. At the Rowe mine the iron-formation is mostly or entirely thick bedded and probably largely wavy bedded. At the Mallen mine the iron-formation is thin bedded, except for 10 feet of partly thickbedded material at the top. On the basis of this difference in lithology Wolff has separated the mines by the "Sagamore-Menomin Lake fault" and placed the ironformation at the Rowe mine in the "Lower Cherty" and at the Mallen mine in the "Upper Slaty"-a minimum of 1,590 feet higher in the stratigraphic succession. In the new Carlson-Nelson open pit (not shown on these maps) in the $S W 1 / 4 \mathrm{NW}^{1 / 4}$ and in drill samples from the $\mathrm{SE} 1 / 4 \mathrm{NW}^{1 / 4}$ sec. 17 , both thick-bedded and thin-bedded facies are present, the thick-bedded stratigraphically overlying the thinbedded. In the Carlson-Nelson open pit, the normal transitional contact between the facies was readily observed; faulting had no part in bringing the thickbedded iron-formation against the thin-bedded ironformation at this place.

The Sagamore-Menomin Lake fault of Wolff also cuts belts of iron-formation that drilling data show to be continuous between the Alstead mine and Portage Lake, between the Arko mine and the south edge of June Lake, and between the Joan No. 1 mine and the northeast end of Menomin Lake. At each of these places the distinctive beds older and younger than the iron-formation also occur on both sides of the "fault" and are presumably also continuous across it. At the Joan No. 1 mine there is, in addition, a layer of decomposed tuff or flow several tens of feet thick interbedded in the younger sedimentary rocks about 15 feet above the top of the iron-formation. This decomposed volcanic rock also occurs above the iron-formation beneath the northeast end of Menomin Lake, west of the "fault." Part of the problem of explaining the facies changes in terms of a fault was recognized by Grout (Grout and Wolff, 1955, p. 54) : "Actual maps are not easily interpreted. For example, a magnetic line runs through secs. 8 and 9, T. $46 \mathrm{~N}$., R. $29 \mathrm{~W}$., crossing the supposed Sagamore fault without any prominent offset or change in intensity."

The writer considers the foregoing evidence sufficient to prove that the "Sagamore mine-Menomin Lake fault" show by Wolff does not exist. It is interesting to note that the "fault" closely parallels a line along which the thin-bedded facies pinches out to the northwest beneath the thick-bedded facies ( $p l$. $5)$.

The four iron-formation members proposed by Wolff are shown in the same fault block in only one place in the district. In the vicinity of the Merritt mine, he 
shows the "Pokegama formation" as succeeded in normal order by the four members of the Biwabik formation, but one small group of drill-hole records for the $\mathrm{NE} 1 / 4 \mathrm{NE} 1 / 4$ sec. 32 is the only evidence for the presence of the "Lower Cherty" beds. Examination of samples from the 4 holes in this group indicated that only 1 hole penetrated iron-formation and is no more than 11 feet thick; the iron-formation is not of the "Lower Cherty" type, but thinly laminated "slaty" material intermixed with pebbles from the glacial drift and underlain by greenish-gray argillite or slate (fig. 12). The writer interprets the ferruginous samples as (1) a shallow narrow infolded syncline of the same thin-bedded facies found at the base of the iron-formation at the Merritt and Gloria mines, or (2) a thin horizontal layer of Pleistocene pebbles and boulders, including at least one boulder of oxidized iron-formation, cemented by iron oxide similar to Pleistocene conglomerate found just above the bedrock in several places in the district. The spacing of the drill holes is such that there can be no more than 60 feet of iron-formation present even assuming that the beds dip vertically, whereas the Lower Cherty member as described by Wolff (Grout and Wolff, 1955 , p. 57) is 100 to 250 feet.

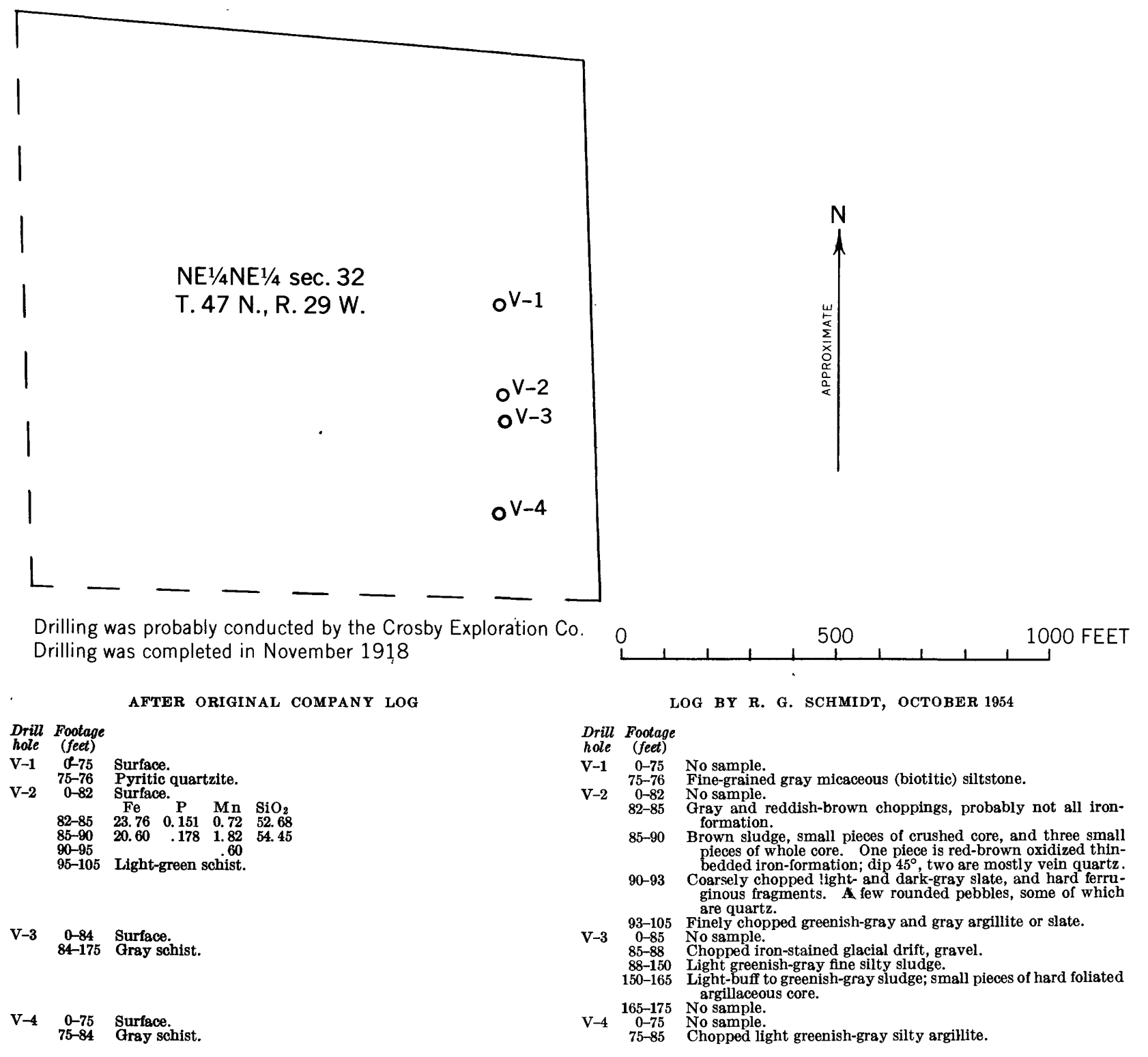

FIGURE 12.-Tabulation of data from exploration drilling in the NE $1 / 4 \mathrm{NE}^{1 / 4}$, sec. 32, T. 47 N., R. 29 W. 
Many samples were examined from 35 drill holes shown on Wolff's map in the "Pokegama formation" in secs. 32 and 33 and from the "Pokegama formation" and the "Upper Slaty member" separated by a fault in the SW1/4 sec. 34. All the samples were similar light-gray argillite and slate, containing minor amounts of quartzite and sandstone, and all the bedrock has been classified as Mahnomen formation; apparently the "Upper Slaty member" is not present here, and there is no known basis for the inferred fault. The iron-formation at the Merritt mine has been shown by closely spaced drilling to be continuous with that at the Pontiac property in sec. 34 , and no abrupt lithologic changes are known. The thin-bedded facies at the Merritt mine thins gradually southeastward to the $\mathrm{NE}_{1} / 4 \mathrm{SW} 1 / 4$ sec. 33 , where it pinches out, reappearing in the $\mathrm{NW}^{1} / 4 \mathrm{SE} 1 / 4$ sec. 33 , and thereafter thickening very gradually to the northeast. To explain this gradual thinning and elimination of the lower part of the iron-formation, a fault would need to follow a most circuitous course around the drag folds or would have formed before folding. Samples were examined from 23 holes northeast of the iron-formation in the SW1/4 sec. 33 and north of the iron-formation in the SE1/4 sec. 33, and in sec. 34. These holes penetrated mainly red-brown and gray to black argillite and slate, but gray and brown material in the $\mathrm{NE}^{1} / 4 \mathrm{SW} 1 / 4$ and $\mathrm{NW} 1 / 4 \mathrm{SE} 1 / 4$ sec. 33 is probably tuff or flow and is similar to materials found in the Maroco and Joan No. 1 mines and beneath Menomin Lake a short distance to the south and southeast. These samples were classified as representing the Rabbit Lake formation.

It has been shown that the same layer of ironformation and the lithologic characteristics of the beds above and below the iron-formation continue without interruption through an area near the Merritt mine where a group of faults had been inferred by Wolff, which makes it extremely improbable that any faulting is of the indicated magnitude. Similarly, belts of iron-formation and associated strata were shown to extend across the "Sagamore- Menomin Lake fault" in four places. It can only be concluded that the faults do not exist. Furthermore, the fourfold subdivision of iron-formation seems invalidated by the many places where different "members" separated by supposed faults have been demonstrated in this report to be stratigraphically equivalent.

It has been shown that the lithologic differences in the Trommald formation are facies changes in the same relatively thin stratigraphic unit rather than separate unique parts of a relatively thick stratigraphic section as proposed by Wolff. Examination of ac- cessible mine exposures and of all available drill samples have established the continuity of the belts of iron-formation and the transitional nature of the lithologic changes as presented in this report.

\section{SOUTH RANGE}

As a part of the study of the North range a few samples from the South range and many samples from between the South and North ranges in the vicinity of Crosby and Cuyuna were examined. In Aitkin County, near Hassman (pl. 1), the same general stratigraphic sequence was found as in the North range: a weakly metamorphosed thin-bedded ironformation is underlain by light-gray argillite and overlain by dark-gray and black titaniferous argillite. The bottom of this sequence is on the northwest side. The iron-formation resembles the thin-bedded facies of the Trommald formation on the North range. Samples of the iron-formation and wallrocks from other places on the South range were examined, but the stratigraphic succession was not determined. Black titaniferous slate and light-gray and brown slate are associated with a silicate-magnetite iron-formation.

Many drill samples from the area south of the North range in secs. $1,9,11,15,16,17$, and $20, T$. 46 N., R. 29 W., and secs. $21,28,29,31$ and 32 , T. 47 N., R. 28 $W$., have been examined and, except for a few that provided no basis for classification, all were identified as belonging to the Mahnomen formation. The slate and argillite underlying the area between the North and South ranges are therefore older than the main iron-formation of the North range and older than the iron-formation in part and probably all of the South range. The gap between the ranges, as narrow as 3 miles in one place, has not been well explored by drilling; but the close resemblance of the stratigraphic sequence in part of the South range to that in part of the North range and the age of the iron-formation in both ranges relative to the argillite and slate in the intervening area make the suggestion of correlation of the iron-formations seem proper at this time. Obviously, more work must be done on the stratigraphy of the central and southwestern parts of the South range before a positive correlation can be made.

The suggestion that the Trommald formation and related Mahnomen and Rabbit Lake formations of the North range are also the dominant stratigraphic units in the northeastern part, and probably all the South range, is in contrast to the proposal made by Grout and Wolff $(1955$, p. 4) that the iron-formation on the South range is a separate layer intercalated stratigraphically higher in the Virginia formation. Their 
reasoning depends heavily on the supposed fourfold subdivision of the iron-formation in the North range and on several ways in which the iron-formations are believed to be different.

The differences are listed by Grout and Wolff (1955, p. 4) :

The following features, now well established, justify making a distinction, since in all five points the North Range (Biwabik) differs from the South Range member: the South Range member has (1) very little chert-and what there is has thin lamination, (2) no manganiferous ore (Zapffe, 1933, p. 83), or only small amounts, (3) no more than 200 feet of iron-bearing beds, (4) barren slates for thousands of feet above and below the iron-bearing bed, and (5) a structure dominated by one belt, in one major syncline, but with a few faults and some minor drag folds.

The scarcity of manganese ore in the South range is not a unique feature in the Cuyuna district because much of the iron-formation of the North range is equally deficient. Furthermore, Grout and Wolff (1955) had no difficulty in correlating the manganiferous iron-formation of the Cuyuna district with the nonmanganiferous ones of the Emily and Mesabi districts.

Two hundred feet is also a very reasonable figure, in the writer's opinion, for the average thickness of iron-bearing beds-the Trommald formation-in the North range. Grout and Wolff have proposed a stratigraphic succession of great thickness in the North range by combining the thicknesses of strata in various inferred blocks. The continuity of the Trommald formation and the adjacent stratigraphic units across these supposed faults in several places disproves the fault hypothesis and destroys the concept of thousands of feet of iron-formation, which was based not only on superposition of equivalent parts of the section from different areas in the district, but also on inclusion of great thicknesses of nonferruginous sedimentary rocks.

Except for the presence of the upper iron-formation lenses in parts of the North range, "barren slates" occur for 2,000 feet above and 2,000 feet below the Trommald formation, the most important ironbearing beds in that area. Upper iron-formation is more abundant in the northwestern part of the North range and is less abundant in the central and southwestern parts; general absence along the southeast edge may be related to general absence of those beds 500 feet or more above the base of the Rabbit Lake formation, in which the upper iron-formation is normally found. Absence of upper iron-formation on the South range might only mean a complete disappearance of the lenses to the southeast. It has not been proved, however, that upper iron-formation is absent in the South range, for short, discontinuous strips if iron-formation are mapped in many places paralleling the main South range iron-formation and 1,000 to several thousand feet from it.

The structures in the South range are perhaps somewhat simpler than those in the North range, but this difference has no bearing on the stratigraphic equivalence.

Another difference, the absence of granular textures in the South range (Grout and Wolff, 1955, p. 85), would be expected because the thick-bedded facies is absent in that range.

In the North range, granules are generally very rare in the thin-bedded facies, though they are locally abundant, and they are more abundant in the thickbedded facies.

\section{CORRELATION WITH THE EMILY AND MESABI DISTRICTS}

The main ore-producing unit of the Cuyuna North range, the Trommald formation of this report, has been variously correlated with formations of the Animikie group of the Mesabi district, either as the equivalent of the Biwabik formation or as interbedded iron-formation in the Virginia slate that overlies the Biwabik.

The present study of the district has not been specifically concerned with correlations outside the district, and little new evidence was gathered regarding the correlation. Much new evidence may be available in the future, as a result of extensive exploration in the Emily district to the north; and full consideration of this evidence, not possible at this time, should be made in any new attempt to study the stratigraphic correlations between the Mesabi and Cuyuna districts. In the progress of this study the writer has found no reason to consider a general correlation of the Trommald and Biwabik formations invalid.

The Mahnomen formation is dominantly argillaceous, compared to the more arenaceous Pokegama quartzite of the Mesabi district. The Mahnomen formation is at least 2,000 feet thick in contrast to the Pokegama, which has a thickness of 350 feet or less in the western Mesabi district and pinches out in places in the eastern Mesabi.

The Trommald formation is far more variable in thickness and lithologic characteristics in the small area of the North range than is the Biwabik formation in any similar area of the Mesabi district. At the west end of the Mesabi district where the Biwabik formation should most closely resemble the Cuyuna district iron-formation, the Biwabik consists of a "cherty" layer overlain by a "slaty" layer, opposite to the normal Cuyuna sequence in places where both 
facies are present. White (1954) described the Emily district succession as similar to the west Mesabi, but included a third, cherty layer at the top.

The Rabbit Lake formation of the Cuyuna includes basalt flows and large lenses of siliceous iron-formation not reported from the Virginia slate, and probably more carbonaceous than the Virginia.

\section{KEWEENAWAN SERIES}

No sedimentary rocks of the Keweenawan series have been identified in the Cuyuna district. Horizontal flows in the South range east of Brainerd are described by Van Hise and Leith (1911, p. 215) and provisionally classed as Keweenawan.

\section{CRETACEOUS SYSTEM}

Cretaceous sedimentary rocks have not been positively identified in the Cuyuna district, although hard ferruginous conglomerates resting on an eroded surface across Precambrian rocks have been tentatively so called because of their resemblance to Cretaceous conglomerates in the Mesabi district (Van Hise and Leith, 1911, p. 215; Grout and Wolff, 1955, p. 83). These ferruginous conglomerates are probably all Pleistocene in the Cuyuna North range.

\section{PLEISTOCENE SERIES}

Pleistocene sediments cover most of the Precambrian bedrock of central Minnesota. They entirely blanket the rocks of the Emily district and the Cuyuna North range and, except for a few small marginal outcrops, completely overlie the South range.

Pleistocene deposits cover the North range to depths of 16 to more than 200 feet, and are 400 feet deep or perhaps deeper in other parts of the district. Pleistocene geology of the North range has been studied in great detail by $\mathrm{L}$. N. Weiss, but the report on his study is not yet complete. Surficial geology of the area was described by Leverett (1932), and the general story of the Pleistocene in Minnesota has been discussed by Schwartz and Thiel (1954, p. 150-171).

Coarse pebble and boulder conglomerate containing rounded fragments of a great variety of rocks ranging in diameter from a fraction of an inch to almost a foot is very thoroughly indurated with a brown iron-oxide cement at one place in the Arko mine, Cuyuna North range. It rests in a deep cut or groove gouged and polished in the bedrock by the Pleistocene glaciation. The conglomerate is very similar to those observed in various other mines and to that described in the literature, and the writer believes that all the coarse ferruginous conglomerates in the Cuyuna district should be called Pleistocene unless local evidence indicates otherwise.

Pleistocene deposits in the North range rest on an irregular but generally horizontal surface that was vigorously scoured by ice movement before deposition began. There is no indication of the amount of Precambrian rock that was removed by the scouring. Fine striations and large grooves are abundant on the surface of the harder beds, especially on the unoxidized thin-bedded facies of the Trommald formation and on quartzite in the Mahnomen formation. These hard rocks form roches moutonnées exposed by stripping operations at the Arko mine and other places (fig. 13). Though probably not more than a few tens of feet, the relief of this surface may be very sharp, for the sides of resistant knobs and the walls of gouged trenches are in places nearly vertical. The resistant roches moutonnées in places are located close to soft saprolitic bedrock; glacial scouring by no means, therefore, completely removed all easily eroded material.

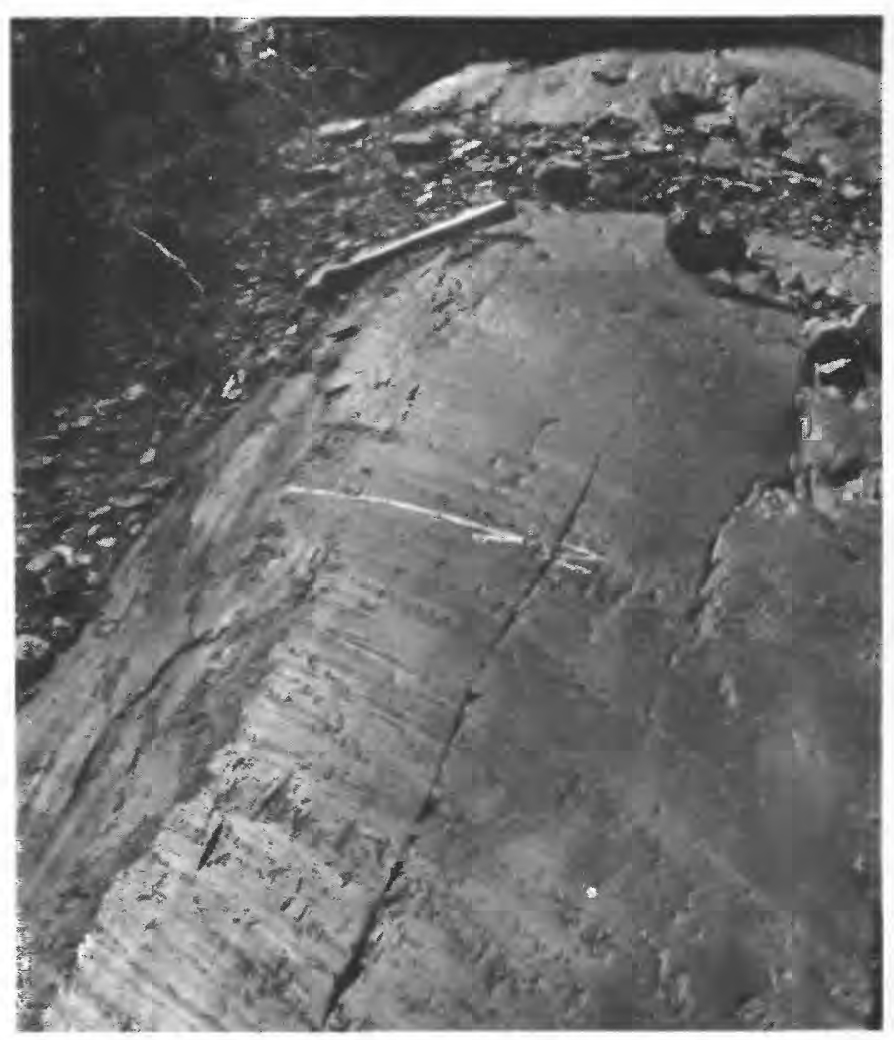

Frgure 13.-Polished and striated roches moutonnée of unoxidized thin-bedded Trommald formation exposed by stripping of glacial drift in Arko mine. The strike of beds parallels the conspicuous crack in the foreground; the dip is nearly vertical. The north arrow is 1 foot long.

Most of the glacial drift exposed in the open pits is stratified sand, silt, gravel, and clay. Unstratified 
till is also abundant. Locally the lowermost few feet, especially in depressions in the bedrock surface, is gravel or boulder conglomerate very firmly cemented by brown iron oxide. The lowermost beds in part of the Pennington and the Hopkins mines were a firm limy claystone or shale, perhaps 10 feet thick, containing scattered pebbles of assorted rocks as much as half an inch across. Thin layers of woody peat and large lenticular masses of peat are interstratified in a few places. Remains of two species of bison have been described and those of a reindeer mentioned by Hay (1923). Bone of Elephas sp. has been reported from near Brainerd (Stauffer, 1945, p. 27). Wellpreserved fossil wood is fairly abundant.

The surface topography of the district reflects the Pleistocene geology. The-North range has a morainic topography with rolling hills and many undrained swamps and lakes. Northeast of Rabbit Lake the land surface is part of the very flat bed of Glacial Lake Aitkin.

Pleistocene sands and gravels seem to contain very little iron-formation and iron ore of local derivation, even near their base. The scattered pebbles of iron-formation are easy to find because of their distinct appearance, but they are a very small part of the total volume of the drift. Furthermore, many of the pebbles of iron-formation seem to resemble rocks found in the Mesabi and Vermillion districts but not present in the Cuyuna.

\section{IGNEOUS ROCKS}

Two groups of igneous rocks in the Cuyuna North range are known, and several types from the South range have been described in the literature. Dikes are locally abundant. Basalts that are probably flows are interlayered with the lower part of the Rabbit Lake formation.

\section{DIKE ROCKS}

Intrusive rocks of intermediate to basic composition occur in an extensive belt along the southeast side of the North range. All the rock in the belt is thought to be the same general intrusive body, although specimens obtained from different places appear to have been derived from the metamorphism of diorite and gabbro. All the specimens examined were thoroughly chloritized, and some were slightly or extensively sheared. The alteration products are masses of fine intergrown minerals, the relative volumes of which cannot be readily estimated by a grain-count method.

The common minerals are chlorite, epidote, clinozoisite, albite or oligoclase, calcite, and sphene or leucoxene. Edenite, uralite, and probably actinolite were observed. Epidote and clinozoisite have formed within the plagioclase grains.
A specimen collected near the Armour No. 1 shaft on the 600 -foot level was a medium-grained phanerite which is thought to have been a quartz diorite or diorite before metamorphism. Plagioclase, now highly altered, was the dominant mineral, and quartz was present in small amounts; these are the only original major constituents still recognizable. Apatite and long stringers of sphene are accessories. The metamorphic minerals epidote, calcite, and chlorite are abundant.

Thin sections of three samples taken from drill holes in the $\mathrm{NE}^{1 / 4} \mathrm{CW}^{1} / 4$ and the $\mathrm{NW}^{1 / 4} \mathrm{SE}^{1 / 4}$ sec. 11 , T. 46 N., R. $29 \mathrm{~W}$., were generally similar to the rock from the Armour No. 1 shaft, but quartz is present in only very small quantities, if at all. The minerals observed include plagioclase, chlorite, epidote, clinozoisite, hornblende, calcite, and microcline as principal constituents and leucoxene, sphene, and magnetite as accessories. The mineral composition of specimens differ, and it is not known if this is the result of the degree and type of alteration or of variations in the original composition. Similar differences in the chloritized basalts are believed to be largely the result of alteration.

One thin section from the NE $1 / 4 \mathrm{SW}^{1} / 4$ contains the following minerals in the approximate percentages shown: 25 percent hornblende (probably uralite), 24 percent plagioclase (near albite), 18 percent chlorite, 25 percent clinozoisite, 7 percent epidote, and 1 percent sphene. The clinozoisite and some epidote have formed within the feldspar, indicating that considerably more feldspar was originally present. The feldspar is clouded and altered; the percentage shown, therefore, also includes other alteration products. One diopside grain is a residual center remaining after alteration. A few grains are quartz or untwinned clean plagioclase. The sphene grains are of the peculiar cuneiform shape described below. This rock was probably a gabbro.

In the specimen described above and in several others, the sphene occurs in irregular cuneiform grains as large as $1 \mathrm{~mm}$. These poikilitic grains are lacy or fretlike in thin section, and the external and internal boundary planes intersect at angles that suggest a hexagonal crystal habit. The interstices of the grains are generally filled with chlorite. In other specimens from the same area, sphene forms shells of uniform thickness around small irregular masses of a gray opaque mineral, presumably magnetite, probably as a result of separation of the constituent oxides of ilmenite.

A thin section of the freshest specimen obtained from the large. intrusive body penetrated by drill 
holes in secs. 15,16 , and 20 , T. 45 N., R. 29 W., shows this to be a highly altered rock also. The plagioclase is albitized, and other original minerals are completely replaced by chlorite, hornblende, and epidote. Some of the green hornblende is probably near edenite in composition; considerable variation in the composition of the hornblende is indicated by much alteration. The sphene, extremely altered to leucoxene, is in complex, somewhat poikilitic grains. Some grains are roughly wedge shaped; others tend to form a fretwork.

\section{VOLCANIC ROCKS}

Thick layers of weathered chloritized basaltic rock are intercalated at or near the base of the Rabbit Lake formation in several places. The chemical composition of this basalt is very similar to the average composition of Hawaiian basalt (Washington, 1923, p. 361), except that chloritization of the former has produced a higher water content. In part of the Maroco mine, where the basalt is a minimum of 250 feet thick, the basalt rests directly on the top of the Trommald formation or is separated from it by a few inches to about 20 feet of laminated gray slate. At the Section Six mine the basalt rests on laminated gray and black slate from 2.5 to about 10 feet thick. At the Joan No. 1 mine, soft gray unbedded rock that was probably originally basalt rests on 20 feet of laminated slate and argillite. Chloritized basalt like that in the Maroco mine and decomposed rock similar to that in the Joan No. 1 mine are present in samples from many drill holes between the Maroco and Joan No. 1 mines (pl. 3), southwest of the Joan No. 1 and Mangan No. 1 mines, between the Maroco and Section Six mines (pl. 2), southwest of the Section Six mine, and north of the iron-formation in the south half of sec. 33, T. 47 N., R. 29 W. (pl. 3). Similar layers of decomposed unbedded rock are in the same general position at the Manuel and Mallen mines, 10 to 30 feet above the base of the Rabbit Lake formation, and in the Pennington and Armour No. 2 mines. The top of this unbedded rock was exposed in only one place, the Mallen mine, where the rock unit was about 40 feet thick.

The basaltic rock exposed in the open pits is soft gray-green material, in minor part schistose, largely weathered to gray, brown, or red saprolite. A small amount of chloritized but relatively unweathered rock has been found in the centers of joint blocks. This fresh material was used for a chemical analysis (table 6, sample 1199) and in the preparation of thin sections. The rock is a fine intergrowth of chlorite-type minerals and lesser amounts of clinozoisite, calcite, and leucoxene. Clinozoisite and leucoxene roughly preserve part of the original grain outlines, which indicate a uniformly aphanitic texture, except that phenocrysts 0.5 to $1.0 \mathrm{~mm}$ across were developed in a few specimens. Calcite grains as much as $3 \mathrm{~mm}$ long are probably porphyroblastic. In some saprolite many voids 1 to $3 \mathrm{~mm}$ long were probably occupied by calcite or pyrite before weathering. The basalts are generally much more weathered than adjacent argillite and slate.

The basaltic layers were extruded as flows during accumulation of the Rabbit Lake formation, or they were injected as sills probably before folding. If flows, extrusion took place in at least three stages as there are lenses of sedimentary rock interlayered with basalt at two horizons in the Maroco mine. There is no distortion of these relatively thin lenses of interlayered bedded rock. One lens is about 40 feet thick and at least 900 feet long; the other is 20 feet thick and of unknown length. The basalts are conformable with the bedding wherever they have been observed and, if they are sills, were injected before or at an early stage of folding. It cannot be established from the information available whether the basalt layers are flows or sills; but after consideration of their concordance over an area several miles square and their failure to distort the thin lenses of interlayered sedimentary rock, the writer believes that they are flows. They contrast with later sills and dikes along the southeast edge of the district, which are generally tabular in the plane of the fold axes and, though locally approximately conformable, are known to cut across a great stratigraphic thickness.

Rocks that have been tentatively identified as tuffs have been found within about 100 feet of the base of the Rabbit Lake formation at many places in all parts of the North range. They occur as coarse to fine and thick to thin beds intercalated with laminated gray or black argillite (fig. 14). The layers are generally well sorted and many have graded bedding; no crossbedding was found. The grain size ranges from $1 / 2^{-}$ inch fragments down to that of the fine argillites with which they are interbedded. Beds with grains at the base more than a quarter of an inch across are several feet thick, beds with sand-sized grains at the base are from less than 1 inch to 2 feet thick, but finer tuff beds cannot be distinguished from laminated argillite. Beds that might be called volcanic breccias because they contain large size fragments are uncommon. Several such breccias have been noted in drill cores from near the Maroco mine, and one exposure of a breccialike rock was examined in that mine.

Individual sand-sized grains or pellets in the tuffs are flattened and elliptical or spindle-shaped in cross 


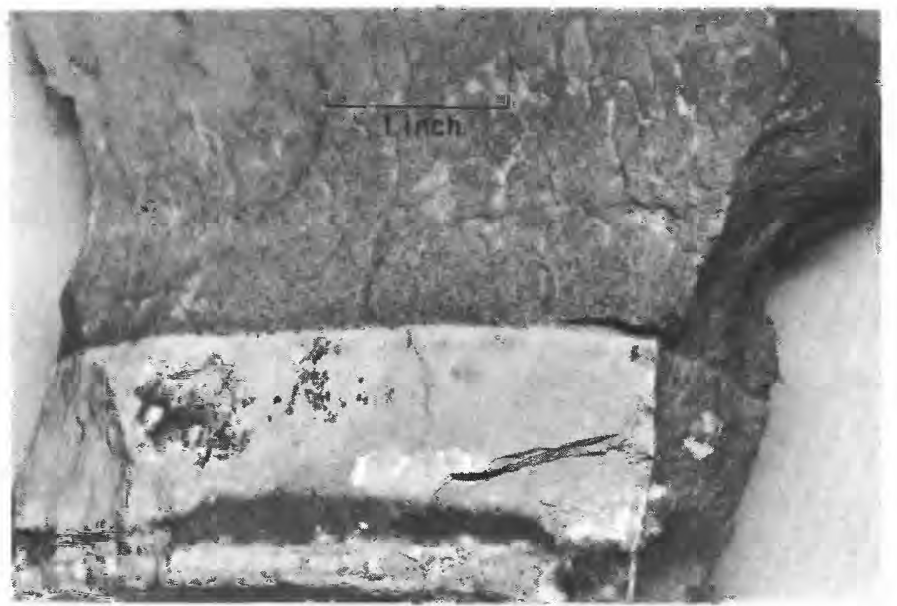

Figure 14.-Tuffaceous layer overlying a light-colored bed of titaniferous argillite, Maroco mine. Note gradation in grain size in upper bed.

section, and they are composed of a fine-grained mixture of clay minerals, probably kaolin and muscovite, and minor amounts of orthoclase, quartz, and leucoxene. No clastic quartz grains were observed, and the absence of this material seems particularly significant. By contrast, large clastic quartz grains are relatively common in the underlying Trommald and Mahnomen formations and in most parts of the overlying Rabbit Lake formation. The absence of clastic quartz grains in sand-sized sediments indicates an unusual source for the material comprising these beds and suggests that the supply of "normal" clastic material was relatively small. The tuff is generally titaniferous, ranging from 1 to 4 percent titania; the enclosing argillite is also titaniferous. The clay grains or pellets that substitute for quartz in a sandstonelike rock may have been formed by the sorting, rounding, and perhaps leaching of local basaltic pyroclastic material. They may also have been detritus derived from basalts exposed on a nearby land area. The coarser beds, fragments half an inch in diameter and larger, would have required strong currents within the depositional basin to have been transported from a distance. The absence of ripples and crossbedding and the very fine lamination of the argillite layers suggest that the bottom was quiet during deposition of the beds. It is assumed that all glassy fragments would have been devitrified in these old rocks, and the absence of grain shapes characteristic of tuffs was not considered significant, though well-preserved shards were found in the Gunflint district (Goodwin, 1956, p. $587)$.

The writer considers that the medium- and coarsegrained water-deposited beds are composed chiefly of basaltic pyroclastic material derived from a local source, sorted, rounded, and perhaps leached by the waters in which the particles were deposited. Conclusive comparisons between the chemical compositions of the suspected tuff beds and known basaltic tuffs are impossible because the compositions of basaltic tuffs vary so much, depending upon the weathering conditions where they were deposited, such as the seasonal distribution of rainfall (Wentworth, 1938).

The tuff beds are best exposed in the Maroco and Joan No. 1 mines, near the base of the Rabbit Lake formation. In the Maroco mine many tuff layers are between the base of the formation and the large mass of basalt and in a large lens of argillite within the basalt; a small exposure of coarser breccia-size material was at a stratigraphically higher point, underlain and overlain by basalt. One medium-grained bed exposed along the access road is about 6 feet thick. Many beds a few inches to a foot thick are exposed above the base of the formation on the northwest side of the Joan No. 1 mine.

Exposures of similar granular beds were seen in the South Hillcrest and Armour No. 2 mines and in drill samples from near the Rowe mine, between the Section Six and Maroco mines, and between the Maroco and Joan No. 1 mines.

Several types of spotted or knotted slate are a few feet from the base of the Rabbit Lake formation, especially in unbedded layers associated with rocks believed to be tuffs or flows. They are characterized by one of several features: light-gray or light-brown spots conspicuous on cleavage surfaces, irregular hard knots, elliptical or irregular space fillings of soft white clay, or elliptical or irregular masses of crystals or relic material with crystalline form. One specimen from the north bank of the Pennington mine has elliptical space fillings of muscovite. The spots, regardless of type, are from 0.1 to $2 \mathrm{~cm}$ in length, commonly 0.5 to $1.5 \mathrm{~cm}$. They may be equidimensional, but most are distinctly flattened in the plane of the cleavage. The spots may be plainly visible on the cleavage surfaces of many specimens, but cannot be seen on other surfaces. The spotted slates were observed in the Joan No. 1, Mangan No. 2, Pennington, Armour No. 2 pit, and Manuel mines.

\section{VEINS AND FRACTURE FILLINGS}

The iron-formation and related rocks of the Cuyuna district are cut by many small veins, and there are abundant vugs and open spaces now containing an interesting variety of minerals.

The veins are of two general types: those containing the same minerals found in the metamorphosed rocks and doubtlessly related to the period of meta- 
morphism, and those containing the minerals associated with the oxidation of the iron-formation and other rocks; the relationship of a few minerals is not known. No evidence was found that the veins formed by replacement of the walls.

Most of the veins that cut the rocks in the Cuyuna North range have developed along the major joint direction that is normal to the fold axes.

Those veins that formed at the time of metamorphism tend to contain minerals that are also found in the adjacent wallrocks. The veins in the Mahnomen formation tend to be quartz, and those in the cherty parts of the iron-formation are largely quartz. Where iron-formation is minnesotaite rich or stilpnomelane rich, the veins may be stilpnomelane only or stilpnomelane and quartz (fig. 15); where siderite rich, veins tend to be siderite and quartz; and where grunerite rich, dominantly grunerite. Grout has reported that where the iron-formation is acmite bearing (Grout, 1946a, p. 127) the veins also contain acmite, and Blake has found some minnesotaite in the veins (Blake, 1958). Chlorite and pyrite occur in minor amounts in stilpnomelane-quartz-siderite veins in the Portsmouth mine. Stilpnomelane veins and stilpnomelane-quartz-carbonate veins were seen in the North Hillcrest, Arko, Portsmouth, Sagamore, and other mines. Irregular olive-green to yellow-brown cryptocrystalline quartz veinlets were observed in unoxidized and oxidized iron-formation in the Arko and other mines. Grunerite veins cut grunerite-rich iron-formation on the dump of the Milford mine. Coarse vein grunerite from the Portsmouth mine was given to the writer by Daniel Chilton, but it is not known if adjacent iron-formation was grunerite bearing.

In some of the tourmaline-bearing ferruginous slate in the Portsmouth mine, the tourmaline occurs in fine reticulating veinlets instead of the more common scattered crystal groups.

Vein minerals in oxidized iron-formation were formed by alteration of preexisting veins or by precipitation of vein material in new fractures, vugs, and openings of breccias.

Alteration of the older veins has yielded many quartz-goethite and quartz-hematite veins, and many containing various manganese minerals. A peculiar type of vein found in many places in the district consists of quartz and nontronite. These veins are ordinarily less than an inch in width and occur where the thin-bedded facies of the Trommald formation has been altered to a nontronitic rock, generally in the intermediate zone between unoxidized and oxidized ironformation. The nontronite-quartz veins are probably alteration products of preexisting veins, which the

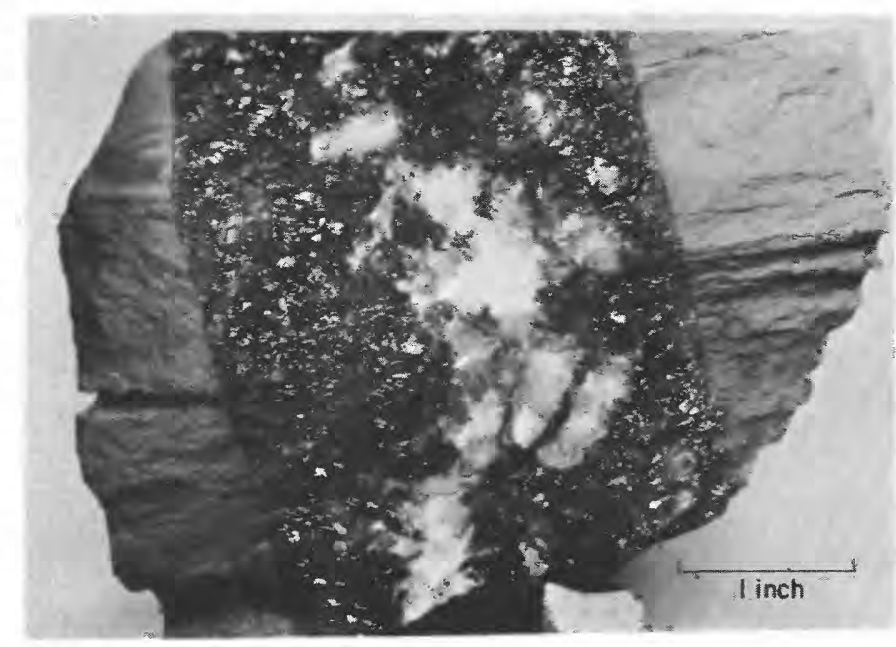

Figure 15.-Stilpnomelane-quartz vein cutting silicate-rich thin-bedded Trommald formation, North Hillcrest mine. The vein is nearly perpendicular to the bedding.

writer believes contained stilpnomelane or minnesotaite and quartz.

Several mines in the central part of the North range have exposed peculiar sheared quartz-hematite and quartz-goethite veins that contain an unusual and beautiful variety of chatoyant quartz. This material is highly esteemed by lapidarists of the area and has been called binghamite. The chatoyancy seems to be caused by minute needles or plates of hematite in the commonest red variety and of goethite in the yellow variety. The iron oxide minerals are probably pseudomorphic after some other mineral.

Later vein, vug, and breccia fillings, probably deposited at some stage of the oxidation of the adjacent iron-formation include a great variety of minerals, such as quartz, calcite, siderite, rhodochrosite, hematite, goethite, manganite, pyrolusite, groutite, and cryptomelane.

Veins of showy manganese minerals formed at many places, especially near the base of the Trommald formation and in fractures and openings in quartzite close to the top of the Mahnomen formation. Manganite, groutite, and cryptomelane fill fractures as much as several inches wide. Calcite and goethite also occur abundantly in the same and similar places.

Small specularite veinlets were found at various places, but the relative age of the formation of these veinlets was not determined. Specularite and a material identified by Mary Mrose as an unknown strontium-bearing mineral of the plumbogummite group are associated in a specimen from the 525-foot level of the Armour No. 1 mine. Other vein material of indeterminate age include minute amounts of galena in weathered quartz-stilpnomelane veins from the Sagamore mine. 
Barite of unknown origin in the Alstead mine was observed as vein filling, as 1 - to 4 -inch tablets and crystal groups in a soft leached bed of the Trommald formation of the North Hillcrest mine, and as 1- to 6 -inch concretionary rosettes of small pink to brown , crystals in the oxidized iron-formation in the Sagamore mine.

Several vein minerals described by Thiel (1924a) as from the Cuyuna range were not observed in the North range by the writer; these are microcline, epidote, albite, adularia, diopside, and biotite. Presumably the epidote was actually acmite (Grout, 1946a, p. 125), and the biotite was stilpnomelane, which is abundant in veins.

No particular relation between any of the veins described above and the formation of ore could be established. The possible relation of red ores and brown ores to joints is discussed under origin of the ores; but no veins were regularly associated with these particular joints. Quartz veins and quartz-carbonatestilpnomelane veins cut unoxidized iron-formation, and similar veins, now oxidized, cut oxidized ironformation. In some places, locally oxidized ironformation is spatially related to large veins, but this is probably the result of surface waters gaining more ready access to the iron-formation along fractures and openings in the veins, not to reaction with the walls when the veins were formed.

\section{STRUCTURAL FEATURES}

The Precambrian bedrock of the Cuyuna district is tightly folded into doubly plunging folds trending about N. $65^{\circ} \mathrm{E}$. The Trommald formation is the principal stratigraphic marker because the relatively much thicker older and younger formations are practically without known internal subdivision. Most of the exploratory drilling has been concentrated in or near the Trommald formation, and therefore the delineation of major structural features in the district is based mainly on the mapped patterns of this unit. The characteristic features of the pattern are large irregular ellipses and complex areas of roughly parallel bands that are irregularly connected as the reversed plunges cause convergence or divergence of the bedrock exposures of the folded units (pl. 2). Several of the bands of Trommald formation have been only sporadically explored, and the structural relations are partly or entirely unknown.

Drag folds are abundant in all sizes and bear a normal and systematic relation to the principal folds. "Cross folds," actually recognized as undulations of fold axes or reversal of plunge directions, may be present in most of the district but could be mapped in detail in only one place, the Portsmouth mine (pl. 3 ). The cross folds were probably a part of the main deformation, but they may represent a separate period of folding.

The faults recognized in this study have been limited to small displacements important within a particular mine but not significant in the district as a whole. Some large-scale faults were suspected during the study and are discussed in a subsequent paragraph.

Joints are abundant in most of the iron-formation. The dominant joint direction is about $\mathrm{N} .35^{\circ} \mathrm{W}$. and vertical, hence perpendicular to the fold axes. Flow cleavage is abundant, especially near the axes of the folds, in argillaceous parts of the Mahnomen and Rabbit Lake formations and in silicated parts of the Trommald formation, particularly in minnesotaiterich rock.

\section{FOLDS}

The three Precambrian formations in the Cuyuna North range have been tightly folded into several large doubly plunging folds. Bedrock surrounding most of the North range is the Mahnomen formation; the oldest of the three formations. The Trommald and Rabbit Lake formations occur as irregular ellipses and long narrow areas that are synclines flanked by and underlain by Mahnomen formation. The axes of the major folds are not ordinarily mappable, except where indicated by the areal pattern of the Trommald formation, and only the synclines containing Trommald and Rabbit Lake formations stand out as distinct folds; the intervening anticlinal areas lack distinctive form, and their major axes can generally be only approximated. The bedrock pattern of the district is, in effect, one of major synclines and relatively inconspicuous major anticlines.

The axial planes of almost all the folds dip steeply southeastward, and the southeast limbs of the synclines are overturned in most places.

There are four major synclines in the North range. The large open syncline extending from sec. 32, $\mathbf{T}$. 47 N., R. 29 W., near the Merritt mine, northeastward to sec. 21 , T. 47 N., R. 28 W., east of Rabbit Lake, is well outlined by drilling except at the northeast end. An overturn to the northwest is shown by the dips of the fold flanks and by the general outline of the structure. Dips of about $60^{\circ} \mathrm{SE}$. are general along the northwest flank; but the overturned southeast flank also dips rather more irregularly from $50^{\circ}$ to $85^{\circ} \mathrm{SE}$.; however, one dip of $75^{\circ} \mathrm{NW}$. was observed west of the Pontiac shaft.

Drag folds near the southwest apex of this syncline are very striking. The origin of the MerrittJoan No. 4-Ferro orebody is perhaps related to the 
intense drag folding. The drag folds shown at the northeast end of the syncline, excepting a small fold near the Northland mine, are all inferred from very sparse drilling data, and further exploration will probably necessitate considerable change in the map pattern. Folds of the upper iron-formation lenses within the Rabbit Lake formation in the central part of this fold have been sketched in from only a few drill-hole data, and the fold outlines should be considered only rough approximations.

Another large syncline plunges southwestward from a point north of the Joan No. 1 mine in sec. 3, T. 46 N., R. $29 \mathrm{~W}$. The fold flanks diverge for about 1.5 miles then extend southwestward nearly parallel for several miles until the decreased amount of exploratory drilling precludes inferred continuation. Unlike the other major structural features, the southeast limb of this syncline does not appear to be generally overturned, although data are less abundant than in other areas. Normal dips as low as $25^{\circ}$ and $45^{\circ}$ were observed in drill cores from near June Lake, and a vertical dip is in core from near Little Rabbit Lake. In the Arko, Mangan No. 1, and Joan No. 1 mines, numerous folds complicate the general attitude of the major fold limb, and some overturned strata were observed in each place on the flanks of the drag folds.

The other two major synclines are about half as long as those described above, each being about 3 miles long, and are much narrower and seemingly more compressed. One extends from the Rowe mine in sec. 18, T. 46 N., R. 29 W., northeastward to the vicinity of the Armour No. 1 and the Mangan No. 2 mines in sec. 10 , T. 46 N., R. 29 W. (pl. 2). The second extends from the Armour No. 2 pit in sec. 11, T. 46 N., R. 29 W., northeastward to the $\mathrm{N} 1 / 2$ sec. 32 , T. 47 N., R. $28 \mathrm{~W}$. The southeast flanks of these folds dip to the southeast and seem to be generally overturned, although there are few data concerning the northeastern part of the latter fold. The northwest flanks of both folds dip about $60^{\circ} \mathrm{SE}$.

\section{FAULTS}

No major faults were definitely identified in this study of the Cuyuna district, although two have been suspected on the basis of stratigraphic and structural evidence. Both are perhaps a mile or less in length. One of these faults has been inferred at the southwest end of the Sagamore mine where beds near the top of the Trommald formation seem to be overlain by siltstone and argillite of the Mahnomen formation (pl. 4). Abundant local evidence of faulting occurs also in the Feigh and Pennington mines, and it is proposed that one major fault zone may extend from the
Feigh mine or perhaps the South Hillcrest mine, northeastward through the Pennington and Armour No. 1 mines. To the southwest of the Feigh mine and perhaps to the northeast of the Armour No. 1 mine, the fault zone is assumed to pass into a broken anticline in which the southeast flank has been thrust upward. It is possible that the chlorite schist near the east end of the Feigh mine, mapped as a chloritized intrusive, may be a wedge of metamorphosed Rabbit Lake formation similar to the material exposed on the southeast sides of each of these pits. Several wedges of similar schist that seem to increase in size with depth occur in the Pennington and Armour No. 1 mines; these wedges may also be either intrusives or slices of the south wallrock that have been faulted into place (pls. 7, 8).

It must be emphasized that the interpretation involving faulting is only a tentative suggestion and that the writer is unable to propose a simple set of faults that could produce the complex minor geologic features of this group of mines. Faulting may be indicated by the seeming discordance of structures in the underground workings of the Armour No. 1 mine. As suggested under the description of the mine, the complexity of the geology in the Armour No. 1 mine may well be the result of igneous intrusion, faulting, or of both.

Many minor faults were observed during the detailed mapping of the district. Some of them cut sharply across the strike of the fold limbs, but most were strike faults of little stratigraphic throw, probably not more than 20 or 30 feet. Several of the faults observed were related to the broken crests of anticlines.

None of the faults shown by Wolff $(1955$, pl. 2) could be substantiated either by field mapping or from the study of drill samples. The group of faults shown by Wolff extending from the Sagamore mine northeastward to the northeast end of Menomin Lake, thence northwestward to the Merritt mine and beyond, has been discussed (p. 36), and it was concluded that the faults do not really exist. Wolff also showed four smaller faults in secs. 2, 3, 4, 9, and 10, T. $46 \mathrm{~N}$., R. $29 \mathrm{~W}$., none of which the writer could verify from examination of mine exposures or justify on stratigraphic and structural grounds. The places where the faults were supposed to be in the Arko, Alstead, and Mahnomen No. 1 mines were visited with $\mathrm{Mr}$. Wolff, but the writer could see no evidence of faulting. In the Mahnomen No. 1 mine the surface that was mapped as the fault is the contact between the Mahnomen and Trommald formations. Slickensides indicate that some differential movement occurred here 
as in most places where the same contact was observed. The apparent slight angular discordance between the bedding in the two formations was interpreted by the writer as the convergence of bedding in the Trommald formation and axial-plane cleavage in the Mahnomen formation.

\section{METAMORPHISM}

All Precambrian rocks in the North range of the Cuyuna district have been affected by regional metamorphism and perhaps locally by contact metamorphism. The general metamorphic grade is upper chlorite zone or lower biotite zone over the entire North range, with slightly higher grade of definitely biotite zone rocks in a few places along the southeast edge of the North range. Very locally, part of the rock in the Milford mine contains minerals indicating metamorphism in the garnet zone; perhaps this is a contact effect.

\section{SEDIMENTARY ROCKS}

The metamorphic grade of the rocks was judged on the basis of the iron-silicate minerals in the unoxidized parts of the thin-bedded facies of the Trommald formation, the grain size of the quartz in relatively clean layers of recrystallized chert in all the iron-formation, and the minerals present in the argillaceous rocks. The criteria were used as described by James (1955). The iron minerals were studied only in the thin-bedded facies of the Trommald formation because iron silicates are not plentiful in the thickbedded facies nor in the upper iron-formation of the Rabbit Lake formation. Abundant minnesotaite, stilpnomelane, siderite, and lesser amounts of chlorite indicate either the chlorite or biotite zone. No significant difference in the abundance of individual iron-silicate minerals was observed over the area. Magnetite and hematite, abundant in much of the iron-formation, are not diagnostic of a particular metamorphic grade. Grain-sized measurements of quartz were made of all thin sections containing areas of relatievly clean chert, including several from the thick-bedded facies of the Trommald formation and from the upper iron-formation lenses in the Rabbit Lake formation, as well as many from the thin-bedded facies of the Trommald formation. Sizes ranged from 0.02 to $0.14 \mathrm{~mm}$, most of the measurements being between 0.05 and $0.1 \mathrm{~mm}$, corresponding to the limits set by James for the biotite zone.

Grunerite was described by James as an indicator mineral of the garnet zone. It occurs as a fracture filling in iron-formation on the Milford mine dump and in the Portsmouth mine, and as sheaves that are as much as $3 \mathrm{~mm}$ long in certain bedding laminae of iron-formation from the Milford dump. In addition, asbestiform material that was too weathered for identification, but that probably had been grunerite, was found in several places in the district. Most of the vein occurrences of grunerite may be disregarded as indicative of a higher metamorphic grade, for there is no general development of the grunerite in the ironformation. At the Milford mine, however, the grunerite has formed as porphyroblasts in part of the ironformation, which suggests that the rocks have been locally metamorphosed into the garnet zone. Much of the iron-formation in the same dump contains minerals that indicate a lower metamorphic grade, similar to the iron-formation in the rest of the district. The mine is abandoned and nothing is known concerning the size of the more highly metamorphosed mass or the transition to the less metamorphosed rock that is general throughout the North range. The local occurrence of metamorphic material of the garnet zone is perhaps related to the grunerite veins.

Wallrocks closely associated with the iron-formation are largely argillaceous and have been converted by metamorphism to argillites and slates or less commonly to phyllites and schists. Muscovite and quartz constitute the bulk of these rocks; chlorite, biotite, magnetite, and carbon are common accessories. These minerals indicate that the metamorphosed argillaceous rocks are in the chlorite or lower part of the biotite zone.

In one area, however, the rocks of the Rabbit Lake formation have been metamorphosed to chlorite schist and biotite-chlorite schist of a grade slightly higher than most of the argillaceous rocks of the district. On the south sides of the Armour No. 1, Pennington, Feigh, South Hillcrest, and Huntington mines the wallrock is gray-green schist. Only part of the schist contains recognizable sedimentary bedding, and the origin of part of the schist was not determined during this study. However, thin sections of the schist from the Huntington mine and from the Armour No. 1 and No. 2 underground mines, where no sedimentary features could be recognized, were compared with thin sections from localities in which the sedimentary origin of the rock is amply proved by an abundance of bedding at the Pennington mine and by thin intercalated chert beds at the Feigh mine. The similarity of the thin sections is great, whereas the textures do not resemble those in thin sections of thoroughly chloritized igneous rocks in the same general area.

The schistose rocks in the bottom of the Feigh and the Pennington mines are the same general type as those of sedimentary origin cited above and possibly should be classified as metasedimentary also, though 
the writer has tentatively classified them as metamorphosed igneous rocks.

The Armour No. 1 shaft and the old Armour No. 2 shaft, as well as extensive parts of the drifts in each mine, are in chlorite schist. Part of this schist has been derived from metamorphism of the Rabbit Lake formation and part has formed by chloritization and shearing of a quartz diorite, diorite, or gabbro. The origin of most of the chlorite schist in these mines and in the old Ironton and Bonnie Belle mines to the south is not known, however. On the basis of incomplete partial sampling and examination of a few thin sections, it was concluded that a thorough sampling and examination of the schist would make it possible to distinguish metamorphosed intrusive rock from metasedimentary rocks.

\section{IGNEOUS ROCKS}

Two types of igneous rocks occur in the Cuyuna North range, and both have been metamorphosed in the chlorite zone.

In the Maroco and Section Six mines and in other areas drilled in the western part of the North range, basalts are interlayered with the base of the Rabbit Lake formation. The basalts are generally saprolitic, but wherever relatively unweathered, they are thoroughly chloritized. The chemical composition, very close to that of an average of 56 Hawaiian basalts (Washington, 1923, p. 361), suggests that very little alteration has taken place, except for the addition of considerable water during metamorphism of the rock.

The metamorphosed basalt is an aphanitic rock consisting of chlorite and epidote and, in certain specimens, various amounts of feldspar, probably albite, and biotite or muscovite. One specimen contains chlorite, calcite, muscovite, and biotite. All samples contain sphene or leucoxene or both, up to perhaps 5 percent of the volume of the rock.

Most of the bedrock in a long narrow belt along the southeast edge of the North range is thoroughly chloritized medium-grained intrusive rock, part of which is believed to have been quartz diorite or diorite and part gabbro. The common minerals-chlorite, epidote, clinozoisite, albite or oligoclase, calcite, and sphene or leucoxene-are those normal in igneous rocks of intermediate to basic composition that are metamorphosed in the chlorite zone.

\section{MINERAL DEPOSITS}

\section{IRON ORES AND MANGANIFEROUS IRON ORES}

The iron ores and manganiferous iron ores of the Cuyuna district have, with minor exceptions, formed in and from the iron-rich sedimentary rock called iron-formation. The iron-formation, as originally deposited, contained from 20 to 35 percent iron and from 0.5 to 16 percent manganese. Commercially usable ores must generally contain 45 to 50 percent iron plus manganese, the variations being determined by ultimate use of the ore and market conditions. Some ores are direct shipping, but others are produced by beneficiation of lower grade materials from which a marketable product can be made by ore-dressing processes. Most of the methods of treatment accomplish the same result as the natural ore-forming process: removal of quartz from the oxidized iron-formation, thereby increasing the proportion of iron and manganese in the remainder. Since 1945, annual shipments of concentrates from the Cuyuna district have slightly exceeded shipments of untreated ore.

\section{IRON-ORE MINERALS}

The mineralogy of the iron ores and marginal iron ores of the district is very simple. Intimate mixtures of hematite, goethite, and quartz make up almost all the ore; rarely does the ore material contain only one iron oxide and quartz. Some ores contain very small amounts of magnetite, and this mineral is moderately abundant in some of the oxidized iron-formation that approaches ore grade. Many of the minerals associated with part oxidized and unoxidized iron-formation are included in the ore shipped. These minerals are iron rich, but their overall effect probably is to reduce the percentage of iron, and they should not be considered as ore minerals. They include minnesotaite, siderite, nontronite, and stilpnomelane. Some siderite probably remains from the original sedimentary rock, but some is secondary and fills cracks and opened spaces in the oxidized iron-formation.

\section{MANGANESE-ORE MINERALS}

Well-crystallized manganese minerals are abundant in replacement textures and space fillings in the ironformation, especially in that which is manganiferous. Only a very small part of the manganese in manganiferous ore occurs as macrocrystalline material; most manganese is finely disseminated as an integral part of the iron ore. Small quantities of disseminated manganese minerals cannot be identified by ordinary $\mathrm{X}$-ray methods, and unfortunately most of the earthy manganiferous ores contain manganese distributed in this way. Of 24 ores studied by $\mathrm{X}$-ray methods, a manganese mineral, manganite, was detected in only three. Eleven specimens of crystalline manganese minerals were examined by $\mathrm{X}$-ray methods ${ }^{4}$ and four

4 Six determinations by F. A. Hildebrand, U.S. Geol. Survey ; five determinations by the author. 
manganese minerals were identified. One specimen was groutite; two specimens contained groutite, manganite, and a trace of goethite; four specimens contained manganite; two contained pyrolusite; and one contained pyrolusite and cryptomelane. The specimen containing pyrolusite and cryptomelane was representative of coarsely crystalline material forming small local manganese-rich ore bodies in the Maroco mine. The frequency of occurrence of the minerals identified by X-ray methods cannot be considered to represent even roughly the relative abundance of the various minerals in the mines.

Many fine specimens of the manganese minerals described above have been found as fracture fillings in quartzite at the top of the Mahnomen formation. The material was derived by migration from the adjacent iron-formation, but the total amount of manganese in such occurrences is insignificant.

\section{MISCELILANEOUS MTNERALS}

Minute traces of several ore minerals other than iron were found in the district, and no relationship was found between them and the iron ores. They are recorded here in case they may be of value to future students of the district.

Several small blebs and leaves of native copper were found in the Virginia mine. One small leaf of native copper was found in loose rock in the Feigh mine, and this almost certainly had come from the bedrock. All were in oxidized iron-formation.

Lane (1924) reported a 0.02 inch seam of native silver in ore and "green diorite" from the underground workings of the Armour No. 2 mine.

Minute crystals of galena were found in a quartzstilpnomelane vein in the Sagamore No. 2 mine.

Malachite staining occurs on weathered pyrite in the Portsmouth mine.

Concretionary masses of barite were found in the Sagamore mine and in the Mahnomen No. 3-North Hillcrest-Alstead mine area.

\section{CLASSIFICATION OF ORE}

\section{COMMERCIAL GRADES OF ORE}

Cuyuna district ores are classified on the basis of the iron, manganese, silica, phosphorus, and alumina analyses and also as direct-shipping ore, concentrates, and sinter. Prices are paid according to a complex formula adopted in 1925 (Wade and Alm, 1955, p. 258261). The Cuyuna North range has produced many grades of ore, which have been diverse in composition and physical properties. Twelve were marketed from the North range in 1956 (table 8).
TYPES OF ORE OBSERVED IN THE FLEID

Several distinctly different types of ore were noted during the study of the mines. Only locally were specific types extensive enough or clearly enough defined to be mapped; most exposures comprise a mixture of textures and types of ore, and no simple classification can be applied.

The bedding and other textural features of the original sedimentary rock are retained in part of the ore, but they have been modified or destroyed in other parts.

\section{IAMINATED ORE}

Oxidation and leaching of thin-bedded iron-formation has locally produced a laminated ore in which all the textural features of the original sedimentary rock are preserved. Removal of silica has rendered the rock porous, in places exceedingly so, and probably has generally reduced the specific gravity, though local replacement of silica or the filling of open spaces by goethite or hematite has increased the specific gravity. Some laminated ores are soft and earthy and particularly porous; others are hard and break readily along the bedding lamination, yielding thin flat plates, similar to the "poker chip horizon" of the Marquette district. Many of the thin flat plates produce a metallic sound when struck. Laminated ore is generally composed of mixtures of hematite and goethite, but in a few places it is composed dominantly of only one of these oxides. Part of the laminated ore contains small amounts of magnetite, and small pieces of the ore can be picked up with a strong magnet.

\section{GNARLED ORE}

Gnarled ore appears rubbly or brecciatea on casual observation, but close examination shows very unusual patterns of small openings and voids. The field term "gnarled ore" was applied because $c$ " the resemblance of some of the material to twisted cracked rotted wood. This general group of textures is present in a relatively large part of the ores in the Cuyuna district.

Gnarled ore is characterized by more or less regular patterns of solid ore enclosing masses of small fragments and plates of ore separated by many openings (fig. 16). The openings appear to have formed by shrinkage, and many of the simpler ones are lenticular. Two general types of gnarled ores were observed, distinguished by the arrangement of the solid material relative to the fractured ore. In columnar gnarled ore, the fractured ore is in parallel columns that somewhat resemble the cells of a honeycomb. Many fractures in an individual column are nearly normal to the axis of the column and tend to be lenticular, the 
iron oxide within the column being divided into thin plates or flakes. Columns range in size from $1 / 4$ to 2 inches in diameter and are as much as 20 inches in length. At one place in the Sagamore mine, where this texture is common, a very fine dark-colored mineral (probably manganese-bearing) coated only the underside of all the plates in the vertical columns.

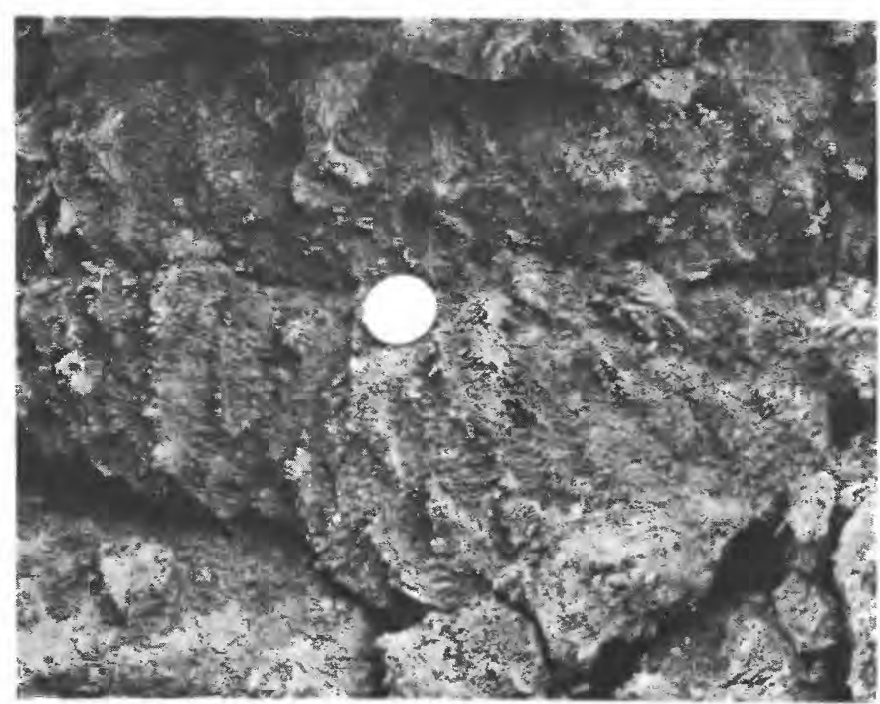

FIgURE 16.-Brown columnar gnarled ore, Sagamore No. 2 mine. The individual columns are about the same width as the coin, which is 1.2 inches in diameter.
In another form of gnarled ore, the fractured ore occupies an ellipsoidal space, about 1 inch and 2 inches in least and greatest diameter, and the ellipsoids are closely spaced in a matrix of solid material. Each ellipsoid tends to resemble the interior of a "limonite" concretion commonly found in sedimentary clays.

The openings in gnarled ore have been produced since folding and without any disturbance of the ironformation; the crumbly material is not a dynamic breccia, and the breaking has no relation to slump structures. The formation of gnarled ore completely obliterates the bedding lamination of the original ironformation. A record of the bedding is retained in most exposures because certain layers in the ironformation were unfavorable for the development of the gnarled texture. These undestroyed beds may be traced from unoxidized iron-formation through masses of gnarled ore and are evidence that no deformation has occurred as a result of formation of the ore.

Gnarled ores have formed only in the thin-bedded facies of the Trommald formation, and probably only in those parts that are relatively free of quartz-rich layers. The ores are almost entirely goethite and are brown or yellow brown; only one small exposure in the Portsmouth mine contained enough hematite to be red.

TABLE 8.-Average analyses of grades of Cuyuna North range ore ${ }^{1}$

[Analysis: D, dry; N, natural. Dry analysis made on ore dried at $212^{\circ} \mathrm{F}$; natural analysis made on ore in its natural condition]

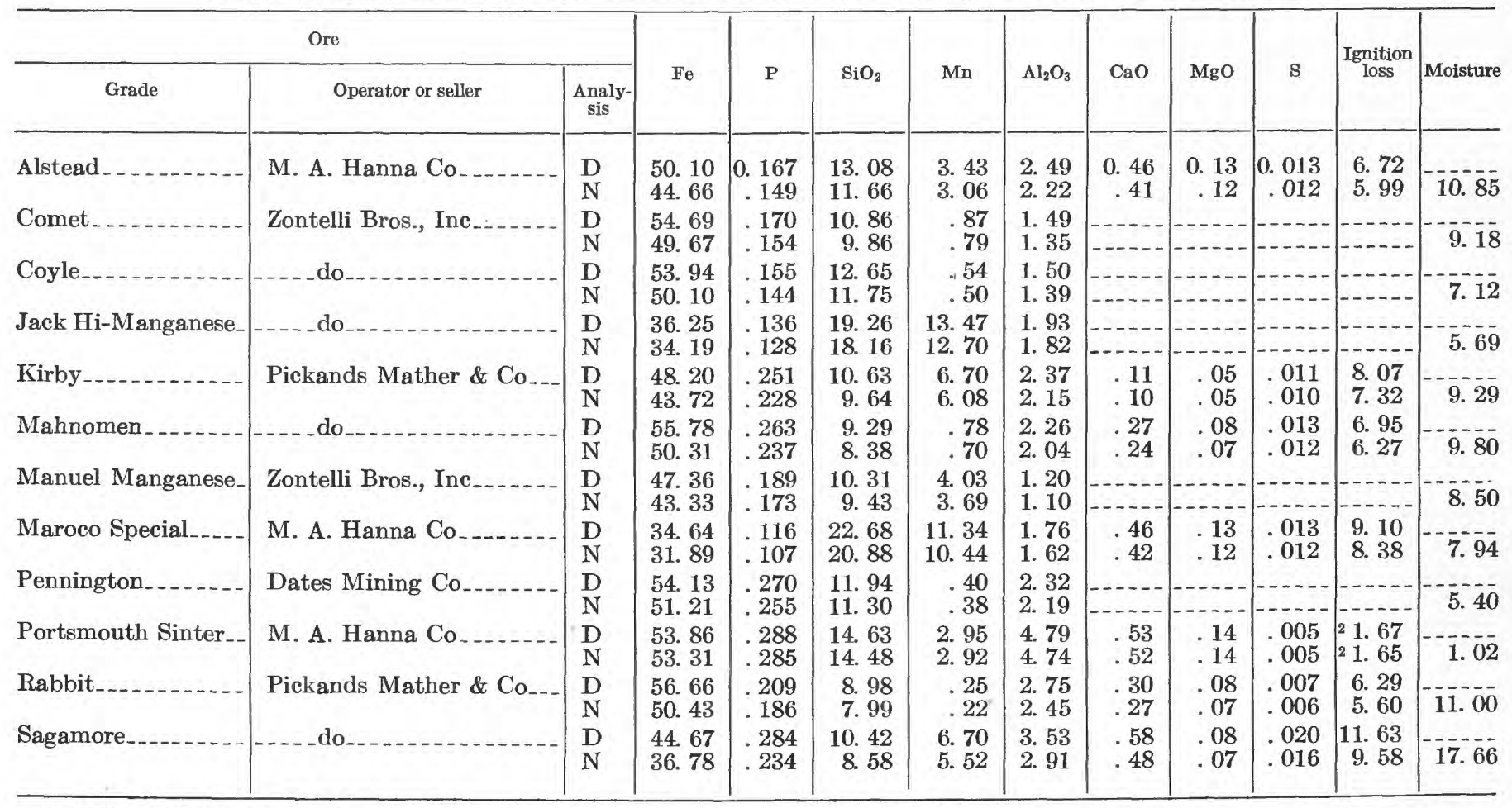

1 American Iron Ore Association (1957), p. 6-7, ore was shipped season 1956.

2 Gain by ignition. 
No explanation of the origin of the gnarled texture is known to the author. Where brown ores, especially gnarled ores, occur next to unoxidized iron-formation, specimens of softened altered iron-formation between ore and fresh unoxidized rock were generally nontronitic to some degree. It could not be determined if the nontronite rock was an intermediate stage in the formation of gnarled ore; if so, the nontronitic stage may be related to the formation of gnarled ore (figs. 17, 18).

\section{BEDDED WASH ORE}

Oxidation and leaching of parts of the thick-bedded facies, especially wavy-bedded iron-formation, and of cherty parts of the thin-bedded facies of the Trommald formation and of the upper iron-formation lenses of the Rabbit Lake formation, have produced wash ores and cherty marginal ores in many places. The iron oxides and quartz generally appear to be more completely separated into discrete layers in the ores than in the unaltered material, indicating that a small amount of solution and reprecipitation has probably taken place. The amount of local solution and redeposition differs greatly, and the resultant ore textures grade from those in which the bedding is dominant to those in which the features produced by replacement are dominant. In thin-bedded iron-formation the iron in siliceous layers seems to have been removed, leaving the layers almost pure quartz; if leaching has progressed far enough, the quartz layers become softened and closely resemble very fine grained quartz sand. The quartz layers are separated by hard or soft layers of mixed hematite and goethite. Ore with hard iron oxide and disintegrated quartz is ideal "wash ore"; the washing process is duplicated on a minute scale on fresh mining cuts when running water or even wind carries the loosened quartz away and leaves parallel ribs of iron oxide standing out from the banks.

\section{WASH ORE WITH CONSPICUOUS REPLACEMENT TEXTURES}

In some wash ore the iron has migrated, probably short distances and has replaced parts of the quartzrich layers rather than concentrating only in iron-
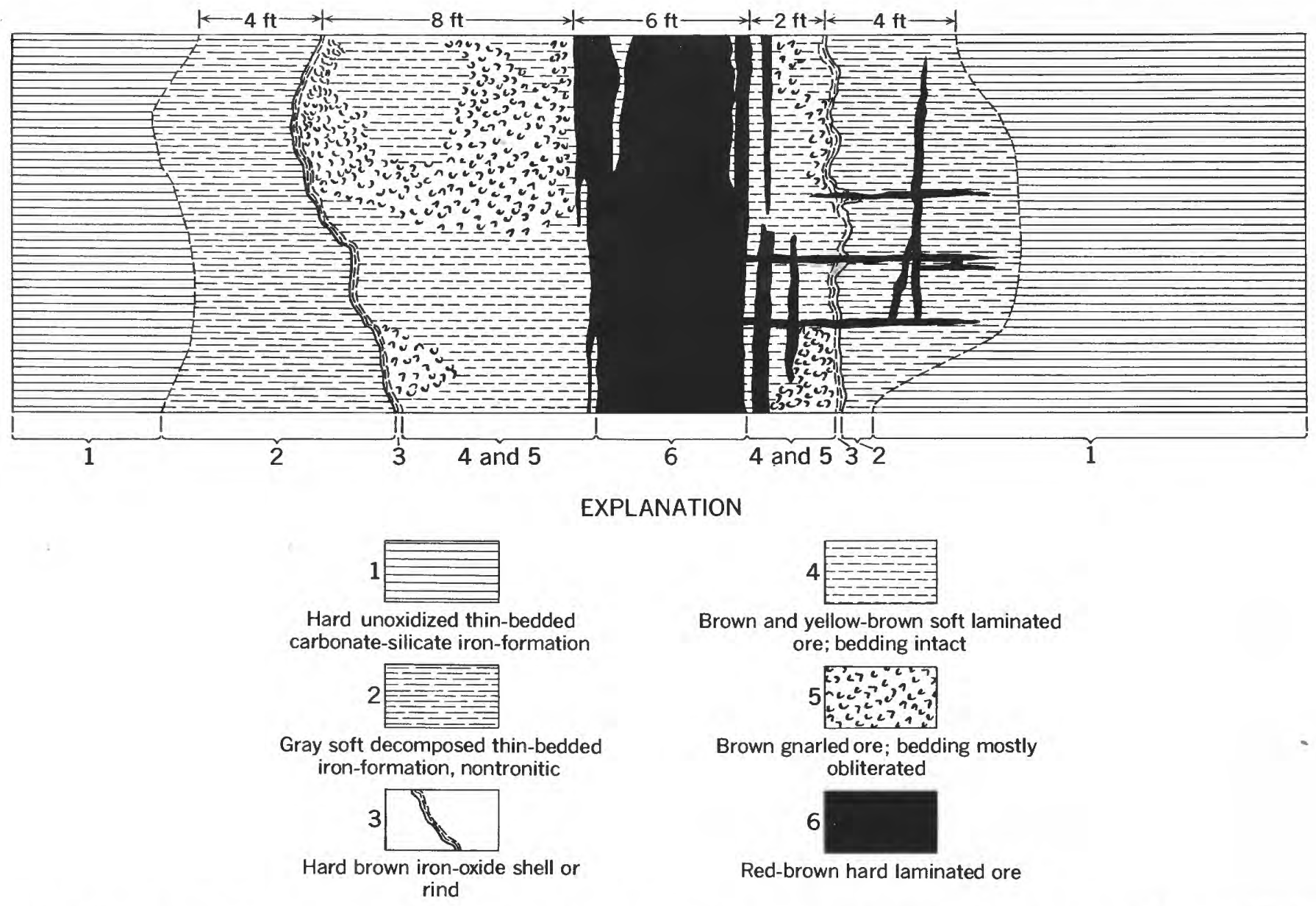

FIGURE 17.-Idealized vertical section showing narrow zone of red, oxidized iron-formation along joints and later associated brown oxidized iron-formation. Adapted from sketch of exposure in North Hillerest mine. 


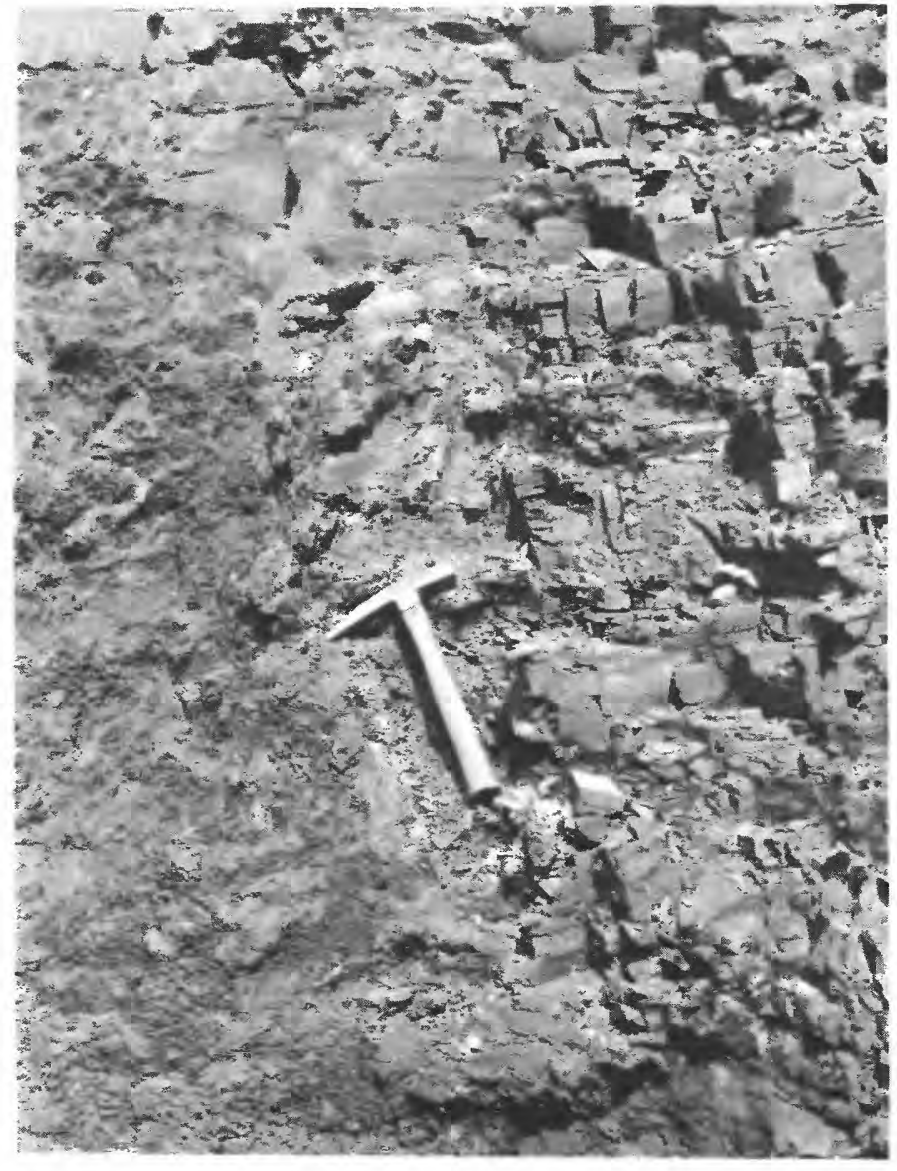

FredRE 18.-Vertical alteration contact of gnarled ore on the left and partly oxidized nontronitic iron-formation on the right, thinbedded Trommald formation, Sagamore No. 2 mine. The point of the pick is on the rind rock; hard unoxidized iron-formation occurred about 5 feet to the right. The bedding is almost horizontal. This was the site of samples 1039, 1040, and 1041 (tables 3 and 4).

rich layers (fig. 19). In a few places large concretionary masses are several feet in length and breadth and 1 or 2 feet in thickness. Ore was formed by development of these large concretions only locally, if at all. More common concretionary growths are a few. inches or less in each dimension, and their development has aided the formation of wash ore. Concretionary growths less than an inch in maximum diameter occur in abundance in certain places, as in the Armour No. 2 open pit, and locally form large masses of ore. Incipient concretionary growth in cherty laminated ore formed small rounded bulges on iron oxide layers by partial replacement of adjacent quartz layers; some layers of quartz contain elliptical concretions of iron oxide scattered or arranged irregularly along bedding and cleavage surfaces. In many places irregular replacement of quartz has started along fractures, cleavages, and bedding surfaces. Replacement textures are probably common on a small scale in

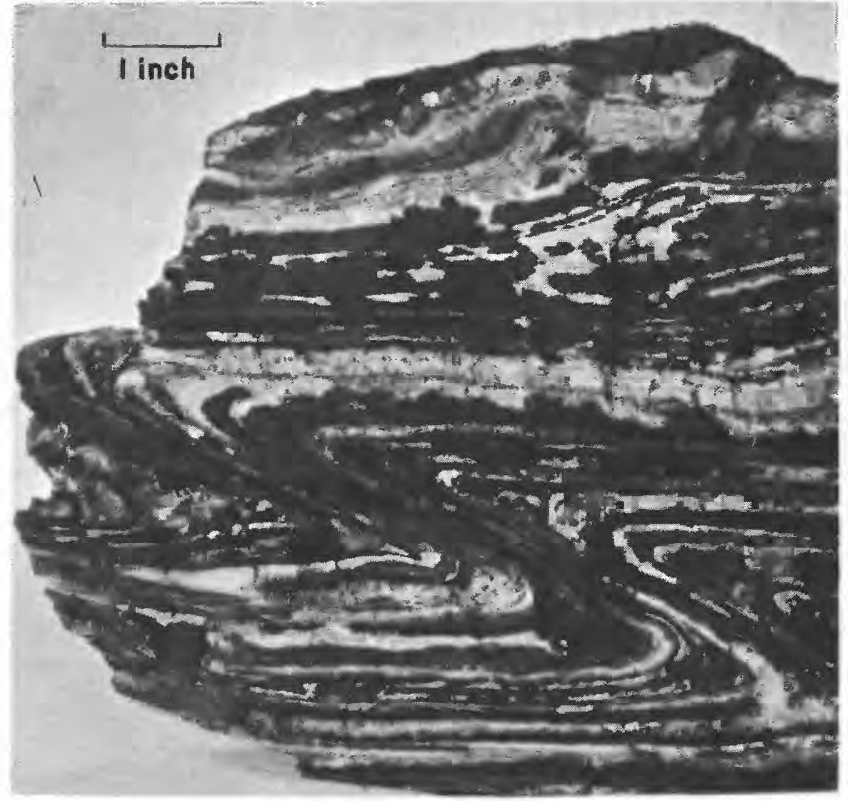

Figure 19.-Drag-folded cherty thin-bedded Trommald formation showing textures caused by local migration of iron and replacement of quartz. Armour No. 2 open-pit mine.

every mine in the district; they were notably abundant in the Feigh, Pennington, Armour No. 2 open pit, Manuel, Rabbit Lake, and Joan No. 1 mines. The textures are found in marginal ore, in which the quartz layers are hard and do not readily separate from the iron oxide, and in wash ore where the quartz resembles loose sand. Large concretions seemed to be more abundant near the transition of thick- to thin-bedded facies, as in the Arko mine, and seemed crumbly or cindery on the inside of a hard shell; the insides of many shells were stained by thin coatings of manganese minerals.

The formation of replacement textures tend to destroy some but not all bedding in the ore. The replacing masses are a mixture of hematite and goethite.

\section{SPECULAR ORE}

Very siliceous specular ore has formed from thick beds of ferruginous chert in the Hopkins, Louise underground, and Merritt mines and other places where the thick-bedded facies occurs, especially near the transition to the thin-bedded facies. Shearing and probably the primary granular texture have together influenced the development of small parallel plates of hematite about one-sixteenth inch across. The hematite plates are set in a matrix of quartz and perhaps earthy iron minerals; by thorough leaching, a specular mass becomes very porous and dull.

Fine-grained specular hematite in veinlets and small masses was observed in the Armour No. 1 mine and a 
few other places in the district. It is negligible as an ore.

\section{CINDERY AND MASSIVE ORE}

These two general types are less well defined than the preceding ones and are in part combinations of the features of many ore textures, including hard and soft laminated, nodular replacement textures, and open-space linings and fillings. The cindery ore breaks into very rough, irregular pieces of both hard and soft ore. Surfaces are variously conchoidal fractures, bedding planes, and the outsides of nodules and small replacement masses. Abundant small voids may be lined by botryoidal iron oxide or small stalactitelike projections. The massive ore, some intimately associated with the cindery ore, is hard, dense, breaks with a conchoidal fracture, and if hematitic, is dark red brown with a blue or purple cast. It may or may not retain fine bedding lamination. Most or all quartz has been replaced by iron oxide. Goethitic ores of these textures are common in most parts of the district, but hematitic cindery and massive ores are particularly abundant types in many mines along the extreme southeast edge of the North range.

\section{SOLUTION-BANDED ORE}

Ores with rhythmic liesegang layering are insignificant in amount in the district, but they have been observed in many places. Alternating layers of iron oxide and fine-grained quartz are arranged in concentric layers around a center. In the Portsmouth mine one small mass a few feet in width and breadth contains layers that are each about 1 inch thick. In the Manuel mine, cherty layers several inches thick contain remarkably well developed solution layering in which the alternating layers are about one-eighth inch thick.

No reason is known for the formation of the rhythmic layering. Formation of this texture tends to destroy bedding; but as the layers seem to form only in certain cherty beds, the bedding of the whole rock remains readily traceable.

\section{DISTRIBUTION OF TYPES RELATIVE TO FACIES}

Gnarled ores were observed only in thin-bedded parts of the Trommald formation, but all other types of ore described above have formed in any kind of iron-formation in all parts of the district. Some types are distinctly more abundant, however, in certain kinds of iron-formation and in certain parts of the district.

Cindery and massive hematite is more characteristic of the thin-bedded facies of the Trommald formation, and large quantities are found only along the ex- treme southeast edge of the North range. Wash ores, both bedded and with replacement textures, constitute almost all the ore in the thick-bedded facies; they are also abundant in the cherty parts of the thinbedded facies of the Trommald formation and in the upper iron-formation lenses of the Rabbit Lake formation. Specular ores are locally abundant in siliceous manganiferous ores derived from the lower part of the thick-bedded facies and its transition to the thin-bedded facies, but they are of little importance elsewhere.

\section{DISTRIBUTION OF MANGANESE IN THE IRON- FORMATIONS}

Manganese occurs in the Trommald formation and in the iron-formation lenses within the Rabbit Lake formation, and it is an important constituent of much of the ore mined in the Cuyuna district. Data on the distribution of manganese in the North range indicate that manganiferous iron-formation is limited to certain general areas and, locally, to specific stratigraphic parts of the Trommald formation.

Drill-hole analyses in the Geological Survey files were used to prepare maps showing the approximate manganese content of the iron-formations at the bedrock surface. The average manganese content was computed from analyses for the top 20 feet of each hole in iron-formation, and the percentage figure was placed on maps of individual land-subdivision sections. The information on these maps was then generalized and placed on a geologic map of the district (pl. 9). Information regarding the distribution of manganese is abundant in parts of the district, but very few analyses are available for some large areas. Many recent analyses have not been obtained from mining companies, but in general these would fill only a small part of the gaps in the information.

Manganiferous iron-formation containing in part of its thickness more than 5 percent manganese in both unoxidized iron-formation and ores is confined to an area occupying between one-half and two-thirds of the North range. Most ores containing more than 10 percent manganese are confined to three smaller areas totaling about one-tenth of the North range: the Sagamore mine area, an area southeast of Menomin Lake, and the extensive area in secs. $22,23,27,28,32$, 33 , and 34, T. 47 N., R. $29 \mathrm{~W}$. In several places in the district manganiferous iron-formation in the Trommald formation is confined to a definite stratigraphic zone, although the zone is not the same in each place. Data suggest that manganiferous and nonmanganiferous belts cut across the strike of the ironformation in secs. 3, 9, and 10, T. 46 N., R. 29 W., 
southeast of Menomin Lake, in a direction approximately N. $60^{\circ}$ W. Additional information might radically change this preliminary conclusion.

At the Sagamore mine the Trommald formation is the thin-bedded facies, which is here locally divided near the middle by a thin argillaceous layer known as the "paint rock." Manganiferous iron-formation occupies a zone in the center of the iron-formation both above and below the argillaceous layer with the most manganiferous ore lying above the layer. The lowermost and uppermost part of the formation is generally nonmanganiferous, including those beds near the top containing chert beds that are probably the extreme edge of the transition to the thick-bedded facies.

In the South Alstead, Hillcrest Extension, and Mahnomen No. 3 mines, in secs. 9 and 10, T. 46 N., R. 29 $W$., the thin-bedded facies makes up from one-quarter to one-third of the total thickness of the Trommald formation and most of the manganiferous ore is confined to the thin-bedded facies and the transition between the two facies. In the South Alstead mine some manganiferous ore is probably also in the thick-bedded facies. East of the Mahnomen No. 3 mine the distribution of the manganese becomes erratic, and west of the South Alstead mine the manganiferous zone disappears. Part of the ore from the Mahnomen No. 1 mine was manganiferous near the center of the syncline and probably represented about the upper half of the thin-bedded facies.

In the vicinity of the Mangan No. 1 mine in lot 6 and the Joan No. 1 mine in the SW $1 / 4$ NE $1 / 4$ and lot 5 of sec. 3 , T. 46 N., R. 29 W. (pl. 3), about one-third of the Trommald formation is the thin-bedded facies, and the manganiferous ore is found in a relatively narrow zone about equally divided between the two facies. A wide zone at the top of the iron-formation in the thick-bedded facies and a narrow zone at the base in the thin-bedded facies are nonmanganiferous. The manganiferous zone of the iron-formation gradually disappears north and west from the Joan mine. South and southwest of these mines the distribution of manganese is very erratic.

In sec. 34, T. 47 N., R. 29 W. (pl. 3), the thinbedded facies constitutes from one-quarter to one-half of the total thickness of the Trommald formation. The manganiferous iron-formation and ore are confined to a zone in the top of the thin-bedded and the bottom of the thick-bedded facies, very similar to the zone at the Mangan No. 1 and the Joan No. 1 mines. Available data are insufficient to outline a manganiferous zone east and west of sec. 34 .

In the vicinity of the high-manganese ore mines (Merritt, Ferro, Algoma, and Gloria) in secs. 28, 32, and 33 , T. 47 N., R. 29 W. (pl. 3), the thin-bedded facies makes up from one-half to perhaps three-quarters of the Trommald formation. Most of the thickbedded facies and part of the thin-bedded facies at its top are manganiferous. Most of the lower part of the thin-bedded facies seems to be nonmanganiferous, except for the local manganiferous material near the base of the unit in the Ferro property, SE $1 / 4$ NE $1 / 4$ sec. 32 , T. 47 N., R. 29 W. Judging from the data available, the manganiferous zone probably disappears to the southeast in sec. 33 . There is no information for the area between the Gloria mine and the Preston shaft in the NW1/4NW1/4 sec. 27, T. 47 N., R. 29 W., where no stratigraphic zoning is evident.

The manganese content is generally very low. where the thick-bedded facies constitutes the entire Trommald formation. A few relatively small high-grade manganese ore bodies formed by replacement and fracture filling in the Maroco mine and probably also in the Rowe mine.

Where the Trommald formation is composed of the thin-bedded facies alone, the iron-formation may be wholly nonmanganiferous as at the Rabbit Lake mine or partly manganiferous as at the Sagamore and Portsmouth mines, and perhaps there are parts of the district where it is entirely manganiferous.

The upper iron-formation lenses contain both manganiferous and nonmanganiferous material, but there are very few data on the distribution of each. The Virginia mine, the only mine ever opened in the upper iron-formation, produced manganiferous and nonmanganiferous ores (Grout and Wolff, 1955, p. 63).

In secs. 20,29 , and 30 , T. 47 N., R. 29 W. (pl. 2), a large area northwest of the Trommald formation is underlain by ferruginous argillite that is locally manganiferous. It is possible that this material is a locally very argillaceous upper part of the Trommald formation, rather than the basal part of the Rabbit Lake formation, as tentatively mapped by the writer.

\section{DISTRIBUTION OF PHOSPHORUS IN THE TROMMALD FORIMATION}

The phosphorus in the Cuyuna ores is largely, if not wholly, derived from the phosphorus present in the unoxidized iron-formation rather than introduced during the formation of ore. The phosphorus in ore, oxidized iron-formation, and unoxidized iron-formation ranges from a trace to several percent in samples taken from different places. Average analyses of most of the ore shipped have been more than 0.045 and less than 0.4 percent, but considerable bessemergrade ore containing less than 0.045 percent phosprous 
was shipped from the Croft and Meacham mines, and Cuyuna ores have been marketed with as much as 0.8 percent phosphorus.

Groups of samples taken from unoxidized ironformation and from ore occurring in the same beds indicate that the phosphorus content changed only slightly as a result of the alteration to ore (table 9), though much variation was observed between the different groups of samples representing different beds.

TABLE 9.-Changes (percent) in phosphorus content produced by alteration of the thin-bedded facies of the Trommald formation to ore

[Results given for numbered samples reading from left to right, respectively] [Complete analyses, locations of samples, and names of analysts for these samples are glven in tables 3 and 4, and boron and germanium analyses for each are shown in table 10]

\begin{tabular}{|c|c|c|c|c|c|c|}
\hline Mine & Sample & $\begin{array}{c}\text { Unoxi- } \\
\text { dized } \\
\text { iron-for- } \\
\text { mation }\end{array}$ & $\begin{array}{c}\text { Partly } \\
\text { altered } \\
\text { iron-for- } \\
\text { mation }\end{array}$ & $\begin{array}{c}\text { Hard } \\
\text { brown } \\
\text { rind ore }\end{array}$ & $\begin{array}{c}\text { Brown } \\
\text { ore }\end{array}$ & $\begin{array}{l}\text { Red } \\
\text { ore }\end{array}$ \\
\hline Mahnomen No. 2 & 1426,1427 & 0.09 & 0.13 & & & \\
\hline $\begin{array}{l}\text { Do } \\
\text { North Hillcrest .- }\end{array}$ & $\begin{array}{r}1428,1429 \\
1431,1432,1430\end{array}$ & & & 0.78 & $\begin{array}{r}0.61 \\
.24\end{array}$ & \\
\hline $\begin{array}{l}\text { Do... } \\
\text { Portsmouth }\end{array}$ & $\begin{array}{r}1433,1434 \\
1932,933,934\end{array}$ & .77 & .57 & & $\begin{array}{l}.21 \\
60\end{array}$ & \\
\hline Sagamore No. 2 & $1039,1040,1041$ & .04 & .03 & & 10 & \\
\hline
\end{tabular}

I Similar iron-formation taken close to, but not stratigraphic equivalent of samples 933 and 934.

Thiel (1926, p. 687) gave an average $\mathrm{P}_{2} \mathrm{O}_{5}$ content of 0.6732 percent for Cuyuna district protore. This seems rather high, perhaps because South range rocks, somewhat more phosphatic, were included, and one unusually high analysis, 4.02 percent, was used in the averaging of seven samples. The writer used 11 analyses of unoxidized thin-bedded iron-formation from the Trommald formation in the North range, all from types of iron-formation that are known to have been altered to ores at other places, and the average was about half as great, 0.34 percent $\mathrm{P}_{2} \mathrm{O}_{5}$. No comparable average analysis of thick-bedded ironformation was obtained because samples are generally partly leached. Ores from mines entirely within the thick-bedded facies are generally low in phosphorus, and presumably this part of the iron-formation contains less phosphorus than the thin-bedded facies. However, the lowest phosphorus ores produced were high-grade iron ores from the Croft and Meacham mines, developed entirely within the thin-bedded facies.

Newton $(1918, \text { p. } 10)^{\circ}$ suggested an inverse relation between silica and phosphorus in Cuyuna ores, which was later emphasized by Thiel $(1924 b, 1926)$ and Zapffe (1925a, 1933). It was generally described as applicable to the manganiferous iron ores, rather than to the iron ores. Newton based his conclusions on the average analyses of a group of ore bodies (Newton, 1918, p. 10-11), but later conclusions were pos- sibly based on analyses of ore shipped from the district. Variation in the phosphorus content of all types of ores is great, and a definite trend exists in commercial grades of both iron and manganiferous iron ores; appraisal of the variation, however, is diffcult.

\section{MAGNETIC ATTRACTION AS RELATED TO THE IRON- FORMLATION}

Magnetite in the Trommald formation, particularly in the thin-bedded facies, produces strong magnetic effects that can be detected readily with simple instruments, such as the magnetic compass or dip needle. Deflections of the compass that were noticed by surveyors and others led to the eventual discovery of the iron-formation by drilling. Because the magnetite in the iron-formation is destroyed by oxidation, the magnetic effects are strongest near the unoxidized iron-formation and are weak or entirely absent near oxidized iron-formation and ore, and also over much of the thick-bedded facies. Detailed relationships of the results of magnetic surveys to the geology of the district will be discussed in a later publication concerned with geophysical studies.

\section{ORIGIN AND OCCURRENCE OF ORE}

The principal iron ores and manganiferous iron ores of the Cuyuna district are residual concentrations of iron oxides and manganese oxides formed from the iron-formations by leaching of silica, carbon dioxide, magnesia, and minor amounts of other constituents; some ore deposits have been formed by local migration of iron and manganese that produced space fillings and replacements of silica.

The source of the solutions capable of leaching silica from the iron-formation and of oxidizing ferrous iron to the higher valence state is problematical. Study of the origin of the Cuyuna ores is also complicated by the great diversity of the ore textures and of the shape of ore bodies. Discussion of the origin of ore has produced several theories, of which two principal ones are currently considered. In the first, the oxidation and leaching are postulated to have been accomplished during weathering by cold downward-moving meteoric waters; in the second, by warm or hot hydrothermal solutions. The general history of thought on the origin of Cuyuna-type iron ore is outlined below.

One of the first theories for the origin of an ironformation in the Lake Superior region was advanced by Foster and Whitney (1851) who proposed that the ores of the Marquette district, Michigan, were igneous, "in some instances poured out, but in others sublimed, from the interior of the earth." 
However, without specific reference to minable ores, Whittlesey (1852) accurately described the "magnetic slates" of the Penokee-Gogebic district as metamorphosed sedimentary rocks.

Formation of the iron ores by alteration of sedimentary rocks seems to have been first suggested by Credner (1869). He proposed that the ores of the Marquette district were formed by the alteration of sedimentary iron carbonate. Irving (1886) extended this idea specifically to the ores of the entire Lake Superior region; and the details of formation of the ores from a sideritic parent rock or from siderite and greenalite were further developed by Van Hise (1889, 1892, 1901), Van Hise and Bayley (1897, 1900), Clements and Smyth (1899), Clements (1903), Leith (1903), and Van Hise and Leith (1911).

Leith, (1907) and Adams (1911a, p. 64-65; 1911b, p. 180) specified that silicate-magnetite iron-formation ("amphibole-magnetite rock") in the Cuyuna district does not ordinarily alter to ore. Adams thought that the amphibole-magnetite rock adjacent to a dike was generally highly resistant to alteration and to penetration by oxidizing solutions, and that it tended to act as a solution dam or barrier as did a dike or sill.

Weidman (1904, p. 142) interpreted the Lake Superior-type iron-ores of the Baraboo district, Wisconsin, as rich layers of primary sedimentary hematite.

Harder and Johnston (1918, p. 130-132) believed that some iron oxide was probably precipitated as a primary sediment in the Cuyuna district, perhaps even in sufficient quantity and of such a grade as to be primary ore; they suggested that this ore might be found at great depths independent of any surfacerelated alteration.

Oxidation by hydrothermal solutions that produced martite ores was suggested by Newland (1922, p. 301). Gruner (1926) proposed the first comprehensive hypothesis of oxidation and leaching of the primary ironformation by hydrothermal solutions rather than by surface weathering, and he presented further arguments in 1932. Gruner (1937) revised this theory by ascribing the extensive oxidation and leaching of the Lake Superior-type ores to surface-derived waters that had been heated and caused to circulate with greater vigor by upward movement of gaseous emanations from large intrusive bodies.

Tyler proposed that the formation of soft ore has been favored by metamorphism of the iron-formation resulting in development of secondary iron-silicate minerals, elimination of chert, and creation of secondary porosity to permit the passage of leaching solutions (Tyler, 1949).
The probability that each of the individual iron minerals was deposited as part of the original ironrich sediments was considered by earlier authors, but James $(1951$, p. $264 ; 1954)$ gave the minerals proper relationships to each other and to the chemical environment in a typical basin of deposition. Four facies of iron-formation were defined on the basis of the dominant iron mineral: sulfide, carbonate, silicate, or oxide. Recognition of these sedimentary facies is especially significant in considering the origin of the iron ore in the Cuyuna district where all four facies are abundant and three or perhaps four have been altered to ore.

Mann (1953) reexamined the weathering and hydrothermal hypotheses and concluded that the soft ores of the Marquette and Gogebic districts, Michigan, were formed by hydrothermal oxidation and desilication of metamorphosed silicated iron-formation. James (1953) questioned Mann's conclusions as to the necessity of metamorphism and silication for the development of soft ores and the evidence presented for hydrothermal activity.

Regarding the origin of the soft ores of the Mesabi district, Minnesota, White (1954, p. 83-84) concluded:

None of the available field, experimental, and theoretical evidence bearing on the manner of origin of the soft ores can be considered at present as absolute proof of either weathering or hydrothermal activity. In the interpretation of available evidence, the conclusions of each observer depend upon his personal emphasis, for either hypothesis is capable of explaining the existing conditions. My personal feeling is that the weathering hypothesis can probably explain the existing conditions better than the hydrothermal hypothesis insofar as the Mesabi range is concerned.

White concluded further (p. 86):

Conditions at some of the other iron ranges in the Lake Superior region differ markedly from the conditions at the Mesabi range and these differences imply variations in the controls of ore genesis.

Regarding the alteration of iron-formation to ore in the Cuyuna district, Grout and Wolff $(1955$, p. 35) considered various evidence supporting both the weathering and hydrothermal theories and stated:

This variety in the processes by which ores are formed after the original precipitation of iron formation makes it difficult to select one process as the dominant one on the Cuyuna Range.

Iverson (1958) and Spencer (1958) discussed the possibility that hot or warm alkaline waters could have been made available for leaching and oxidation when silica gels, deposited as part of the iron-formation, were dehydrated under the conditions of high temperature and pressure of deep burial.

The geology of the Cuyuna ore bodies and related rocks has been carefully studied to determine any 
evidence relating the development of the ores to the weathering theory, the hydrothermal theory, or to any other mode of formation; some very interesting features were discovered though no conclusive results can be claimed. The writer believes there is considerable evidence that the soft ores formed by two somewhat different processes yielding two types of ore bodies that differ in shape, depth, texture, and mineral content (p. 61-62). Speculation on reasons for the differences is very tenuous. The shapes of the ore bodies and the distribution of one trace constituent, boron, in a limited number of samples suggest to the writer that one type of ore body was controlled in some way by the passage of possibly hydrothermal solutions and that the other type is the product of relatively simple deep surface weathering. The writer will try to show that the degree of metamorphism probably had no effect on the localization of ore and that ore has formed within the thin-bedded facies of the Trommald formation in carbonate and silicate rock alike.

Though the Cuyuna district is unique in the Lake Superior region because of the amount of manganese in part of the iron-formation and ore, this difference is not considered to change the problems of the derivation of the ores from the iron-formation. Certain manganiferous iron ore bodies show more extensive replacement and more migration of the ore material than is generally found in ordinary iron ores, but this feature is not a serious complication because manganese is known to be more mobile than iron.

\section{RELATION OF MAJOR ORE BODIES} TO GEOLOGIC FEATURES

A general study of the stratigraphic distribution of ore was made by relating the combined amount of ore produced before 1954 (Wade and Alm, 1954) and estimated ore available in May 1954 (Wade and Alm, $1955)$ to the stratigraphic source, with particular attention to the two facies of the Trommald formation. The combined amount of ore as of May 1954 was $118,125,579$ tons (exclusive of the Rabbit Lake formation and the ore of the Snowshoe mine), and percentages of this figure are used in the following discussion. Except for the Alstead and Louise mines, it was not considered practicable to estimate separately for an individual property the ore derived from the thin- and thick-bedded facies. For seven mines and reserves that include ore from both facies, all the ore in each was assigned to the facies considered to be most abundant. This doubtless introduced some errors, which probably tended to cancel each other; it is probable, therefore, that the total amounts are good approximations.
Almost 99 percent of the ore in the Cuyuna North range was located in the Trommald formation, 0.79 percent in the upper iron-formation lenses of the Rabbit Lake formation and 0.37 percent in the Snowshoe mine in which the stratigraphic position of the ore is not known.

\section{OCCURRENCE OF ORE IN THE TROMMALD FORMATTON}

Within the Trommald formation, 86 percent of the ore occurs in the thin-bedded facies and 14 percent in the thick-bedded facies. These relative proportions also roughly pertain to the bedrock outcrop area of two facies; therefore, the facies are in a general way equally favorable for the development of ore. The two facies differ, however, in areal distribution of ore, types of ore produced, sizes of ore bodies, and probably the process that formed some of the ores; for these reasons the occurrence of ore in each facies is discussed separately.

\section{THIN-BEDDED FACIES}

The thin-bedded facies is exposed at the bedrock surface over about 4.3 square miles. Moderate to strong magnetic anomalies are generally associated with the thin-bedded facies, and partly for this reason exploratory drilling of this facies has been generally more thorough than of the weakly magnetic thickbedded facies. However, areal distribution of ore within the thin-bedded facies reveals a most uneven pattern, showing that controls other than simply the area of the facies at the bedrock surface is responsible for this kind of rock having contained such a large proportion of ore ( $\mathrm{pl} .10)$.

Of the mined ore plus reserves in the Trommald formation, 86 percent occurred in the thin-bedded facies. Of this ore, 97 percent occurred in a milewide belt along the southeast edge of the North range and occupied somewhat more than half of the area underlain by the thin-bedded facies. In this belt, redbrown dominantly hematitic ores are an important part of most of the ore bodies, including all the largest ones, whereas northwest of this belt the ores are mainly brown or yellow brown and are goethitic. The color differences in ore are, however, also generally related to the relative time of formation, to the shapes of ore bodies and the relation to unoxidized iron-formation, and to the boron content of the ore. Taken together, these associations are believed to indicate different origins for the red-brown and the brown ores.

Almost all ore bodies in the thin-bedded facies contain both brown and red-brown ores, making it advisable to divide them into parts and then classify 
each part according to the dominant type of ore; several ore bodies are too heterogeneous to be classified. Brown and red-brown ores were given most careful study in the locations where they occurred side by side, or where either one was adjacent to the parent rock, unoxidized iron-formation. The most desirable places for study were exposures where the same beds could be traced from unoxidized iron-formation to ore and from one type of ore to another. At no place could one bed be traced from unoxidized iron-formation through both red-brown and brown ores.

No difference could be found between the unoxidized iron-formation in the areas of predominantly red ore and in the areas of mostly brown ore that would suggest that the difference in the ores was related to the degree of metamorphism or to the minerals present in the iron-formation before oxidation took place. The metamorphic grade of the iron-formation was practically the same in all parts of the North range, and generally the same variations in the estimated grade prevailed in all places. Perhaps the only possible exception is the Milford ore body, a brown ore body of moderate size probably closely associated with grunerite-bearing iron-formation as well as with rock of lower metamorphic grade.

The hematitic and goethitic ore bodies seem to have formed irrespective of the iron minerals present before oxidation. Where ore bodies, especially brown ore bodies, cut across the bedding of the host rock, there was clearly no preference for the development of ore along beds of a particular mineral composition, and minnesotaite- or stilpnomelane-rich rock appeared to have been converted to ore as readily as carbonaterich rock. There is little unoxidized iron-formation in the near vicinity of the red-brown ore bodies, however; and it is therefore more difficult to show that they have not formed preferentially in certain mineralogic types of iron-formation.

\section{DISTRIBUTION OF ORE MINERALS AND ORE TEXTURES}

In a general, but very striking way, dark red-brown hematitic ore is dominant in the thin-bedded facies of the Trommald formation only in a narrow belt along the southeast edge of the North range; brown and yellow-brown goethitic ore is dominant in the rest of the district. The belt of large bodies of hematitic ore extends from the southwest end of the Sagamore No. 1 mine northeastward through the Mallen, Martin, Huntington, South Hillcrest, Hillcrest Extension, Feigh, Pennington, Armour No. 1, Mahnomen No. 1, parts of the Portsmouth and Armour No. 2, the Croft, North Yawkey, and Rabbit Lake mines; and every large ore producer exceeding 5 million tons-the Saga- more, Mahnomen group, Armour No. 1 and No. 2, Portsmouth, and Rabbit Lake ore bodies-has large masses of hematitic ore in the deepest parts of the mines. The Sagamore mine now produces mostly brown ore, and most of the properties listed also contain important amounts of brown ore. Along the northwest edge of the belt, ores of both kinds occur in the Alstead, Arko, and Mahnomen No. 3 mines, and in both the open-pit and underground parts of the Louise mine.

Gnarled texture is almost entirely limited to geothitic ore, and samples on which X-ray determinations were made consisted almost entirely of goethite. Hard cindery and massive textures are locally found in goethitic ores, but are most abundant in the large hematitic ore bodies.

\section{RELATIVE TIME OF FORMATION}

In the North Hillcrest and Mahnomen No. 2 mines, dark red-brown ores are in narrow zones along vertical joints and vein-filled openings (fig. 17). The redbrown ore is enclosed by brown ore which in some places is a layer a few inches to several feet in width, but in other places surrounds several vertical redbrown zones that merge and form an ore body, as in the Mahnomen No. 2 mine. The formation of red ore before brown ore can be established in a few places and the relationship is probably general. In the dark red-brown ores along vertical joints the details of bedding lamination are commonly preserved; in contrast, the adjacent brown ores are commonly of the gnarled types in which all but a few bedding features are destroyed. Thus, the general destruction of the bedding features in many of the brown ores precludes any possibility that the locally enclosed bedded red-brown ores have formed from them. No conclusions can be drawn at contacts where bedding is entirely or partly preserved in both red-brown and brown ores.

\section{SHAPES OF BROWN ORE BODIES AND RELATION TO UNOXIDIZED IRON-FORMATION}

The ore deposits in the Mahnomen No. 2, part of Mahnomen No. 3, part of the northeast end of the Sagamore No. 1 mine, and small pockets in the Portsmouth mine consist almost entirely of brown ore. Unoxidized iron-formation occurs adjacent to, or exposed within, each ore body. Where the iron-formation is not cherty, gnarled ore textures are common and in places constitute the bulk of the brown ore. The ratio of ore to oxidized lean ore seems to be much higher in the brown ores than in the red-brown ores. The brown ore may be relatively high grade to within a few inches or feet of the related unoxidized iron- 
formation, whereas, the red-brown ores are commonly associated with large amounts of oxidized lean ironformation.

Ore bodies of the brown type are commonly shallow, and in one place in the Sagamore No. 1 mine they have been shown by drill-hole data to pass downward into unoxidized iron-formation throughout a considerable area. The lower limit of oxidation at this place is probably very irregular, is generally horizontal in contrast to the bedding which dips from about $45^{\circ}$ to nearly vertical, and has no features that suggest the localization of ore along synclinal "troughs." Irregular masses of unoxidized iron-formation are beneath brown ore bodies in several mines, and large proportion of these masses crosscut both bedding and folds; but the detailed shape of the very irregular bottom surface of ore or oxidized iron-formation is not generally known.

Some brown ore bodies extend parallel to joints and fractures that are approximately normal to the fold axes, as in the Mahnomen No. 2, part of the. North Hillcrest, and some small pockets on the north side of the Portsmouth mine.

\section{ASSOCIATION OF BROWN ORE WITH NONTRONITIC IRON-FORMATION}

Soft, decomposed iron-formation is generally found between brown ore and unoxidized laminated ironformation (figs. 17, 18) and is abundant in many mines. It ranges from slightly softened but firm rock to very soft claylike material; some is firm but porous; and some is soft but very dense and waxy. Bedding lamination is excellently preserved in all textures except the softest claylike material. The mineral composition of this altered material may differ greatly. Siderite may be abundant or absent, as may goethite. Minnesotaite and stilpnomelane may remain from the parent rock. Most of the specimens studied with the $\mathrm{X}$-ray diffractometer contained a nontronitic clay, which the writer believes is generally present in the soft layer between unoxidized iron-formation and brown ore. The dense waxy specimens were notably nontronitic, and at many places there are also thin veinlets of pale-green nontronite (chloropal) and quartz, presumed to be altered stilpnomelane-quartz veinlets.

The nontronitic rock is commonly separated from brown gnarled ore by a hard irregular layer of goethite, which was called the rind in field mapping. The side of the rind toward the nontronitic rock is rather smooth, dense, and resembles the outside of a limonite concretion; the side toward ore is rough, vuggy, and probably is analogous to the inside of a limonite concretion. Masses of hard goethite similar to the rind occur within the nontronitic rock and within the ore, especially along bedding planes and joints.

The significance of the nontronitic rock and the rind layer in the formation of ore remains unexplained: either or both may be intermediate in the transition from parent rock to ore; however, they may also have formed later than the ore, perhaps under different conditions. Previous authors have discussed the phenomenon. Royce (1938, p. 52) wrote:

The bottom few feet of the ore is always heavily contaminated with clay which has been accumulated from original slaty layers in the formation and has washed down mechanically through the porosity of the ore until it has reached the bottom.

Rejection of Royce's theory seems justified because the clayey layer preserves the undisturbed lamination of the adjacent iron-formation in many places and is also present at the contact if unoxidized iron-formation overlies ore. Gruner (1946, p. 97) stated that nontronite was an intermediate phase in the transition from minnesotaite and stilpnomelane to goethite locally in the Mesabi district.

The amount of iron in the nontronitic rock may be about the same as in the parent rock (table 3, sample 1426 ; table 4, sample 1427) or may be much less than in either the original iron-formation or in the ore, as shown by analyzed samples from the same beds a few feet apart (table 3, sample 1039; table 4, sample 1040, 1041). If brown ores have developed from unoxidized iron-formation by passing through a nontronitic phase, then it would seem that the iron has tended to move freely within the nontronitic zone, perhaps going into solution as the original iron-formation is altered, and reprecipitating on the rind. It is also possible that part of or all the nontronitic rock has developed after cessation of the ore-forming process, wherever the exceedingly permeable brown ores have given ground waters access to unoxidized iron-formation, and that the nontronitic zone was not present during development of most of the ore. If this is true, then perhaps the rind and the generally nontronitic layer are analogous to the kaolinitic layer under residual bauxites on nepheline syenite. Gordon, Tracey, and Ellis (1958, p. 139-149) concluded that most of the kaolin was formed later than the bauxite and under different climatic conditions.

\section{BED-BROWN ORES}

Most of the ore or the deepest part of the ore is dominantly dark-red brown in the Armour No. 2 underground mine, the Rabbit Lake, Mallen, Hillcrest Extension, Pennington, Mahnomen No. 1, and Sagamore No. 1 mines. Oxidized lean ore is abundant in 
the vicinity of these ores, and little unoxidized ironformation is present. Gnarled texture is generally absent in red-brown ore and was seen in only one small exposure in the Portsmouth mine. The redbrown ore bodies commonly are tabular, parallel the dip of the bedding or the wallrock contacts, and extend to much greater depth than the brown ore bodies. There may be a general spatial relation of the red ores to the principal intrusive mass in the district, but no direct genetic relationship is known.

BELATION OF ORE TO STRUCTURE IN THE THIN-BEDDED FACIES

No relationship was found between ore bodies and folds in the thin-bedded facies. Many ore bodies occur in synclines because more iron-formation remains uneroded in the synclinal troughs. Where anticlinal folds of iron-formation remain uneroded, they seem as subject to alteration to ore as the synclines. Many ore bodies are located on the steep virtually monoclinal limbs of large folds, and do not extend downward to the adjacent synclinal trough.

Closely spaced joints normal to the fold axes have controlled the general shapes of several brown ore bodies mentioned above. Minor red-brown oxidized zones that are believed to be peripheral and related to the main areas where red-brown ore was formed also follow these joints, as do most of the various veins.

In the Armour No. 1 mine, a tabular ore body dips steeply beneath a chlorite and biotite schist hanging wall. The nature of the contact and the origin of the chlorite and biotite schist are in doubt; this problem has been discussed in the description of the mine. The contact of the schist with the iron-formation is probably a fault or perhaps the schist is partly an intrusive mass. Whatever the relation, the ore body in the iron-formation is tabular, is close or adjacent to the wallrock contact, locally cuts downward through gently folded beds, and is nearly perpendicular to the bedding.

BORON CONTENT RELATED TO OBIGIN OF ORE

The proposition that solutions from different sources at different times produced the red and brown ores of the thin-bedded facies was tested by a study of the mineral composition and minor constituents of several of the typical ores. Semiquantitative spectrographic and $\mathrm{X}$-ray determinations and chemical analyses were made to find what compositional changes occurred in the alteration of unoxidized iron-formation to each of the types of ore. The mineral associations are simple. Almost all ores are mixtures of hematite and goethite; hematite is predominant in red-brown ores, and goethite is predominant in brown ores. No correlation between crystallinity and the type or texture of the ore was found.

Chemical and semiquantitative spectrographic analyses revealed that only the boron content of the types of ore was significantly different (table 2). Small amounts of boron are in all the ore and in most of the unoxidized iron-formation, where it presumably was a primary constituent of the original sedimentary rocks. Boron is in unusual abundance, as much as 0.6 percent, in thin tourmaline-rich argillites and slates locally interbedded with the iron-formation. Only normal thin-bedded iron-formation and related ore was used in the samples selected for subsequent boron analyses, and the tourmaline-rich argillaceous layers were deliberately avoided.

The results of the boron determinations are shown in table 10. Six samples of unoxidized iron-formation contained from 0 to $50 \mathrm{ppm}$ boron. Four samples of partly oxidized (nontronitic) brown ore and seven samples of brown ore contained 10 to $80 \mathrm{ppm}$, practically the same range as the parent rock. The slightly higher boron content suggested by the latter analyses may be the result of residual enrichment associated with alteration to ore. Six samples of redbrown ore contained from 70 to $200 \mathrm{ppm}$ boron, which is significantly higher than the other two types of material.

Most of the samples were taken in groups or pairs and from the same bed or nearly the same bed wherever possible. The analyses show that the boron content of unoxidized iron-formation differs considerably from place to place, but that they did not significantly change in the alteration of unoxidized iron-formation to brown ores in any sample pair. The boron in red ores, however, was from slightly more to 10 times as much as in samples taken from the same sedimentary bed as brown ores, or as compared to unoxidized ironformation a short distance away. Boron has been introduced into the oxidized iron-formation, from a source outside the formation or by redistribution of the element from boron-rich layers, during or after development of the red-brown ores and preceding the development of the brown ores. This substantiates the hypothesis that in the thin-bedded facies the ores are of two ages and were altered by solutions that were of a different chemical composition.

\section{THICK-BEDDED FACIES}

Of the mined ore plus the reserves in the Trommald formation, 14 percent occurred in the thickbedded facies. These ores consist of both hematitic and goethitic material, and no significant areal pattern was found in the relative abundance of them. 
TABLE 10.-Boron and germanium content of unoxidized thin-bedded facies of the iron-formation in the Trommald formation and stratigrapically equivalent ores in the formation

[Results given for numbered samples reading from left to right, respectively. Groups 1-7: See tables 3 and 4 for complete analyses and descriptions of these samples. Groups 8-10: Determinations by U.S. Geological Survey; borons: Harry Bastron, analyst; germaniums: Peter Zubovic, analyst]

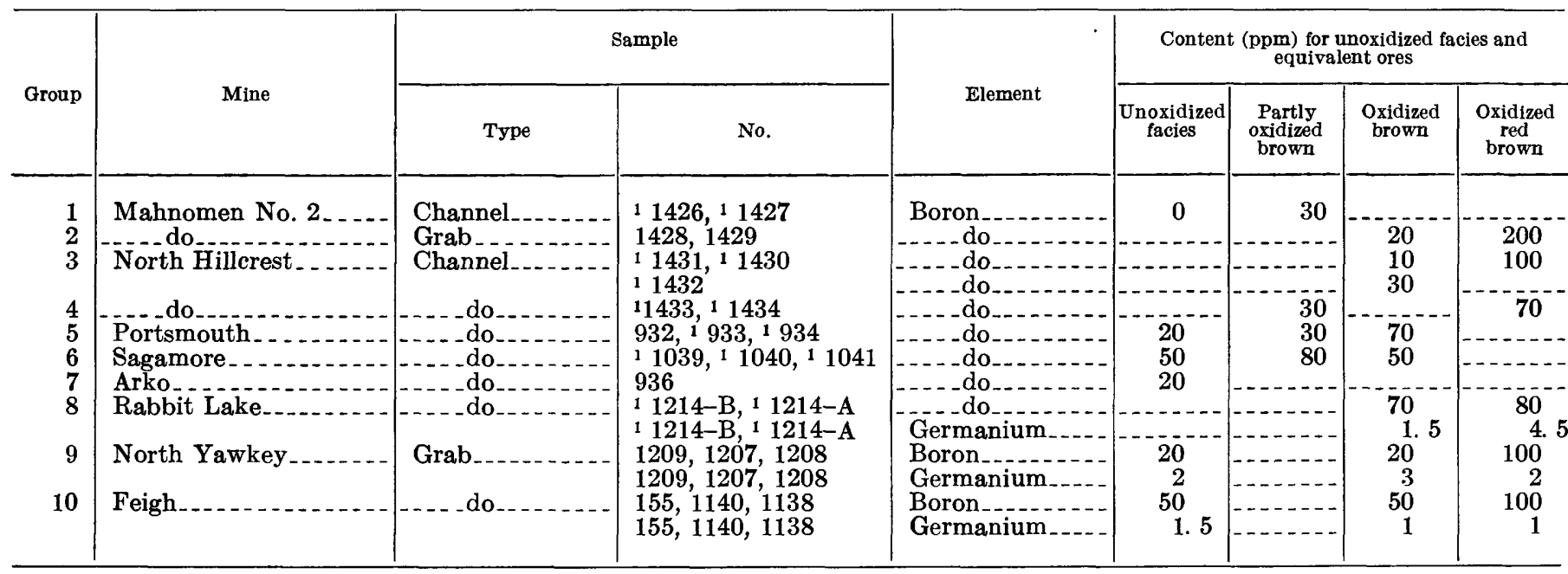

1 Samples within the group were exact stratigraphic equivalents.

Sample:

1214-B. Soft brown laminated ore. Eight-in. channel sample cut perpendicular to bedding, 18 in. from sample $1214-A$, of which it is the exact stratigraphic equivalent. Coordinates: about 2,250 N., 1,800 E, Rabbit

1214-A. Soft red-brown laminated

dicular to bedding (Sample cut perpen(1914- above) Coordinates: about $2250 \mathrm{~N}$ 1,800 E., Rabbit Lake mine, October 1954 . Unoxidized thin-bedded iron-formation. Mineral composition about 60 percent minnesotaite, 30 percent carbonate, 8 percent quartz, 2 percent magnetite. Coordinates: 1,450 N., 1,750 W., North Yawkey mine, September 1954 .

Nearly all the ore mined in the thick-bedded facies has been wash ore requiring beneficiation, or small bodies of manganiferous iron ore that were selectively mined by underground methods.

Ore bodies have formed at scattered points over the entire area in which the facies occurs, about 1.1 square miles (pl. 11) and the position of several large ore deposits in areas of intense drag folding suggests that folding favored the formation of the ore. Folding has also increased the width of the exposure and likewise the minable width of any ore available; this might account for the location of some of the mines on the drag folds.

Most of the high-grade manganiferous ores have been in or near the zone of transition between the thick- and the thin-bedded facies.

\section{OCCURRENCE OF ORE IN UPPER IRON-FORMATION WITHIN THE RABBIT LAKE FORMATION}

The relative amount of ore that has been discovered in the interbedded lenses of upper iron-formation within the Rabbit Lake formation is very small; and only one mine, the Virginia, has been operated in lenses of this younger iron-formation. Most of the ore examined in the mine is laminated, argillaceous, and cherty wash ore or is wash ore with replacement textures. The ore in the mine is both red brown and
Sample-Continued

ple- Brown ore from between red-brown ore (sample 1208) and unoxidized ironformation (sample 1209). Coordinates: 1,300 N., 1,830 W., to 1,380 N. formation (sample 1209). Coordinates: 1,300 N., 1,830 W., to $1,380 \mathrm{~N}$., 1208. Red-brown ore, slightly higher stratigraphically than samples 1207 and 1209. Coordinates: 1,280 N., 1,820 W., North Yawkey mine, September 1209.

155. See table 3 for complete analysis and description of sample. 1140. Yellow-brown ore close to unoxidized iron-formation similar to sample 155 .

1138. Red-brown ore. Coordinates: 2,850 S., 1,200 E., Feigh mine, 1953.

brown. Some of the iron-formation in the Virginia mine and in drill samples from farther east beneath Menomin Lake is exceedingly cherty, and the ferruginous layers make up as little as one-tenth of the volume where the rock grades into ferruginous chert. In the Virginia mine some lean ferruginous chert, in which the bonding between quartz grains has thoroughly broken down resulting in a soft sandy material, was mined and treated in the mill yielding a satisfactory product.

\section{SUGGESTED ORIGIN}

The following proposed origin of the North range ores seems worthy of consideration at this time because, although the substantiating data are not abundant, the theory readily explains most of the various field relations, some of which seem rather unusual. The ores of the district are believed to have been produced in two stages and by two general processes. The stages are recognizable only in the thin-bedded facies of the Trommald formation, but they must be presumed to have been effective in the thick-bedded facies and also in the upper ironformation lenses of the Rabbit Lake formation.

The first, probably hydrothermal, stage of ore development is characterized by deep hematitic oxida- 
tion, the introduction or redistribution of boron and a rough spatial relation to fractured zones and igneous intrusion. Rising hydrothermal waters would have stimulated circulation of ordinary ground waters and accelerated their oxidizing and leaching capacity, perhaps partly by increasing their temperature but probably mostly by increasing their rate of circulation. The resultant ore bodies are large, deep, tabular, and hematitic, for example, those of the redbrown type. The hydrothermal activity was limited to the southeast edge of the North range where it may have followed zones of earlier thrusting and fracturing, especially between and including the Martin and Manuel mines where no continuous major thrust zone could be traced, but fracturing and thrusting were observed or suspected in several places.

Boron was introduced in the first stage or perhaps was redistributed from a few boron-rich sedimentary beds (table 10), and small amounts now present are probably all in the mineral tourmaline. The iron-formation was almost all oxidized in the near vicinity of the stimulated circulation, and the bottom of the ore and oxidized iron-formation has not been reached by exploratory drilling to more than 900 feet below the bedrock surface. Oxidation of the iron minerals probably preceded leaching, but no suggestion of a nontronitic phase with this alteration was seen.

The oxidizing solutions were also active in marginal areas along certain groups of particularly open joints, producing narrow oxidized zones but probably no ore. The oxidized zones were important later because they were much more permeable than the adjacent unoxidized iron-formation and gave an access for weathering solutions that produced brown ore.

It is impossible to estimate how much deeper the Cuyuna red-brown ores may extend and also how great a thickness of bedrock including the red-brown ores has been removed since those ores formed. Ore and the deep oxidation of iron-formation extend to several thousand feet in other Lake Superior regions. Not more than a few hundreds and probably a few tens of feet of bedrock and ore have been removed since formation of the brown ores in the Cuyuna district.

The second stage of ore development took place by the relatively more irregular and widely distributed oxidation and leaching of the iron-formation by ordinary weathering processes. Much of the ore in the thin-bedded facies may have passed through a nontronitic phase in the alteration from unoxidized ironformation. Brown ore formed as an irregular blanket on all exposed surfaces of the unoxidized thin-bedded facies and also on the peripheries of all the preexisting red-brown ore and as shells on all unoxidized residual masses remaining in the red-brown ores. The red-brown ores were relatively permeable and aided the circulation of weathering solutions, thus yielding masses of brown ores at anomalously great depths. Marginal to the areas of dominantly red-brown oxidized iron-formation, the first oxidation process seems to have advanced outward along the joints perpendicular to the fold axes. These narrow early oxidized zones were then enlarged by later brown oxidation, and the brown ores from several such zones coalesced locally forming minable ore bodies such as in the Mahnomen No. 2 mine (pl. 3). Except where it formed along the sides of deep red-brown ore bodies as in the Mahnomen No. 1 (pl. 3) and Sagamore No. 2 (pl. 4) mines, brown ore probably occurs no more than 100 feet below the present bedrock surface. Brown ore is common on the bedrock surface of the thin-bedded facies throughout the North range, though most is too shallow to be minable, and probably blanketed the entire exposure before glaciation. Although the ore blanket has been entirely removed from many places, the remaining brown ore occurs locally in all parts of the North range suggesting that the land surface when the ore formed was nearly parallel to the present surface and was, therefore, one of low relief. The thick-bedded facies of the Trommald formation probably altered to ore in the same second stage by solution along boundaries of quartz grains, and parts of the upper iron-formation lenses in the Rabbit Lake formation probably were similarly changed.

\section{RECOMMENDATIONS FOR FURTHER EXPLORATION}

The recommendations for further exploration made here are generally repetitious of recommendations made in earlier reports (Schmidt, 1958a, 1959). Particularly important in exploration for ore in the Cuyuna North range are the distinctly different characteristic patterns of ore distribution in the two facies of the Trommald formation. Perhaps less important is the general limitation of higher grade ores to the thin-bedded facies, and ores requiring beneficiation occur in both facies of the Trommald formation and in the upper iron-formation lenses within the Rabbit Lake formation. The upper iron-formation lenses have been explored enough to show that they are generally unfavorable, and only the Trommald formation deserves further systematic exploration. 


\section{THIN-BEDDED FACIES}

The previous discussion of the distribution of ore in the Trommald formation has shown that the thinbedded facies along the southeast edge of the North range has been much more favorable for the discovery of ore bodies than the same facies where found farther northwest. Any area of this favorable part thought to be underlain by thin-bedded iron-formation and not already drilled is probably worthy of exploration. A few such areas are indicated below.

The southeast limb of the major syncline extending from the Armour No. 2 mine northeastward to the NW $1 / 4$ of sec. 32 , T. 47 N., R. 28 W. (pl. 2), has been explored very little between lot 5 in sec. 6, T. 46 N., R. 28 W., and the northeast end of the fold, which seems to be completely unexplored. The relatively undrilled southeast limb of this fold has much less magnetic attraction than the partly oxidized northwest limb, suggesting that oxidation may be more general on the southeast side. This limb should be more thoroughly explored.

Drilling data concerning the Trommald formation northeast of Rabbit Lake in the E1/2 of sec. 20 and in sec. 21, T. $47 \mathrm{~N}$., R. $28 \mathrm{~W}$., are very incomplete, and the mapped contacts for this unit are speculative. Much or all of the iron-formation penetrated by drilling in this area is oxidized. The Trommald formation here is about 200 feet thick, most or all of which is thin-bedded facies. The area is located along the southeast edge of the district and not far from the occurrence of ore at the Kennedy and Rabbit Lake mines. The inferred geologic structures suggest a group of southwest-plunging drag folds, which may increase the width of the iron-formation exposed at the bedrock surface. The area is worthy of additional exploration.

In an unexplored area in secs. 9 and 10, T. $46 \mathrm{~N}$., R. $29 \mathrm{~W}$, southeast of the Huntington, South Hillcrest, Feigh, and Pennington mines the areal geology shows that a belt of iron-formation extends eastward from just south of the Huntington mine and may be continuous to the Bonnie Belle mine (pl. 3). The structure in the Huntington, South Hillcrest, Feigh, and Pennington mines has been interpreted as a tight asymmetrical anticline, probably sheared on one or several planes near the axis. Chlorite and biotite schist correlated with the lowermost part of the Rabbit Lake formation occurs along the southeast side of all these mines. A band of iron-formation has been traced by drilling for a short distance eastward beneath the south bank of the Huntington mine and westward from the Bonnie Belle mine into the NW1/4 SE1/4 sec. 10, but no connection has been traced.
Farther south, the Mahnomen formation has been penetrated by many drill holes, beneath the northeast end of Blackhoof Lake in sec. 10, in lot 1 of sec. 16, and in the $\mathrm{NE} 1 / 4 \mathrm{SE} 1 / 4$ sec. 15 , T. $46 \mathrm{~N}$., R. $29 \mathrm{~W}$. Assuming the Trommald formation to be continuous in this part of the district, it probably appears at the bedrock surface somewhere between the south bank of the South Hillcrest and Feigh mines and lot 1 in sec. 16, unless it has been cut out by unknown faults or intrusion. Exploration has been insufficient in an area that appears to be a decidedly favorable location for the occurrence of ore, and more drilling seems definitely justified.

In sec. 19, T. 46 N., R. 29 W., near the Sagamore mine (pl. 4), relatively unexplored thin-bedded facies of the Trommald formation probably occurs southeast of the present mine in a narrow belt from the $\mathrm{SE} 1 / 4 \mathrm{NE} 1 / 4$ to the SE $1 / 4 \mathrm{SW}_{1} / 4$. No limit of the ironformation southeast of the mine has been established by drilling in the $\mathrm{SE} 1 / 4 \mathrm{SW} 1 / 4$, and the lack of strong anomalous magnetic attraction suggests that any ironformation present is thoroughly oxidized. In the east half of the section, the greatest possible width of the unexplored iron-formation is limited by the known presence of the Mahnomen formation to the southeast. This area should receive some additional exploration.

The thin-bedded facies of the Trommald formation on the northwest side of the North range has been extensively drilled, perhaps in part because of strong magnetic anomalies. Relatively little ore has been found, and the area presumably deserves little further exploration.

THICK-BEDDED FACIES

The thick-bedded facies has been generally favorable for discovery of ore bodies in all parts of the district where the unit exceeds 80 feet in thickness and particularly favorable in drag-folded areas. Most ores discovered in the thick-bedded facies will probably require beneficiation. If only the thick-bedded facies is present, ores will be generally low in manganese.

The thickness of this facies is important in exploration. Where only the thick-bedded facies is present, the total thickness of the Trommald formation may range from more than 100 to 45 feet, and perhaps there are places where the iron-formation pinches out. Eastward and northward in the North range the thick-bedded facies overlaps the thin-bedded facies, thins at the expense of the underlying thin-bedded facies, and finally disappears entirely. Where both facies are present and the thin-bedded facies is unfavorable for the occurrence of ore, the gradual thin- 
ning of the thick-bedded facies must be considered an important factor in exploration.

The thick-bedded iron-formation generally contains only a relatively small amount of magnetite and causes little, if any, magnetic anomaly.

Further exploration of the thick-bedded facies is: recommended in sec. 12 , T. 46 N., R. 30 W., where no data are known that trace the Trommald formation southwestward beyond the $\mathrm{NE} 1 / 4 \mathrm{NE} 1 / 4$ (pl. 2). Most drill holes in this section were probably in the Rabbit Lake formation; and all holes in iron-formation, except in the $\mathrm{NE} 1 / 4 \mathrm{NE} 1 / 4$, were in lenses of upper ironformation, not in the Trommald formation. Drilling in the $\mathrm{NE} 1 / 4 \mathrm{NE} 1 / 4$ has indicated a drag fold, similar in shape to the fold at the Section Six mine, and if the belt of iron-formation can be traced westward more drag folds may be discovered.

The southwest end of the belt of the iron-formation in secs. 29 and 30, T. 47 N., R. 29 W. (pl. 2), has not been traced beyond the northeast end of Miller Lake. The iron-formation is all thin-bedded facies where samples were examined in this area, but it may change to thick-bedded if the belt extends farther to the southwest. Previous exploratory drilling in the thinbedded iron-formation has not discovered ore; but should the iron-formation change to thick-bedded facies along the southwestward strike, the chances of finding ore in this part of the district would be greatly increased. Exploration for manganiferous ores might be favorable in the area of facies overlap. If the facies change is verified, magnetic anomalies must be interpreted with care because the thick-bedded facies is very weakly magnetic and the lower part of the Rabbit Lake formation seems to be strongly magnetic here.

\section{EXPLORATION FOR MANGANIFEROUS ORES}

Most of the generalizations made for iron-ores are equally true for manganiferous iron-ores, and the map (pl. 9) presented herein shows the general distribution of manganese in the district. The manganiferous ironores and the less common ferruginous manganese ores are most apt to be found where the thin-bedded facies occurs alone and in both facies where the thick-bedded overlaps the thin-bedded, especially within about 50 feet of the transitional contact. Sites near the transition between the facies include most of or all the rich manganiferous iron-ore bodies that were selectively mined by underground methods in the past.

\section{LOW-GRADE MANGANESE RESERVES}

More than one-third of the ore shipped from the Cuyuna district through 1954, or about 29 million long tons, contained more than 5 percent manganese, and the district has contributed an important part of the manganese production of this country. Most of the manganese has been shipped as a constituent of iron ore (less than 5.0 percent $\mathrm{Mn}$ ) and manganiferous iron ore (5.0-10.0 percent $\mathrm{Mn})$ and a relatively smaller amount as ferruginous manganese ore (more than 10 percent Mn) (table 11).

\section{TABLE 11.-Production of iron ore, ${ }^{1}$ manganiferous iron ore ${ }^{2}$ and ferruginous manganese ore ${ }^{3}$ from mines in the Cuyuna district, $1911-54$, in gross tons}

[Data from U.S. Bureau of Mines Minerals Yearbook (1954)]

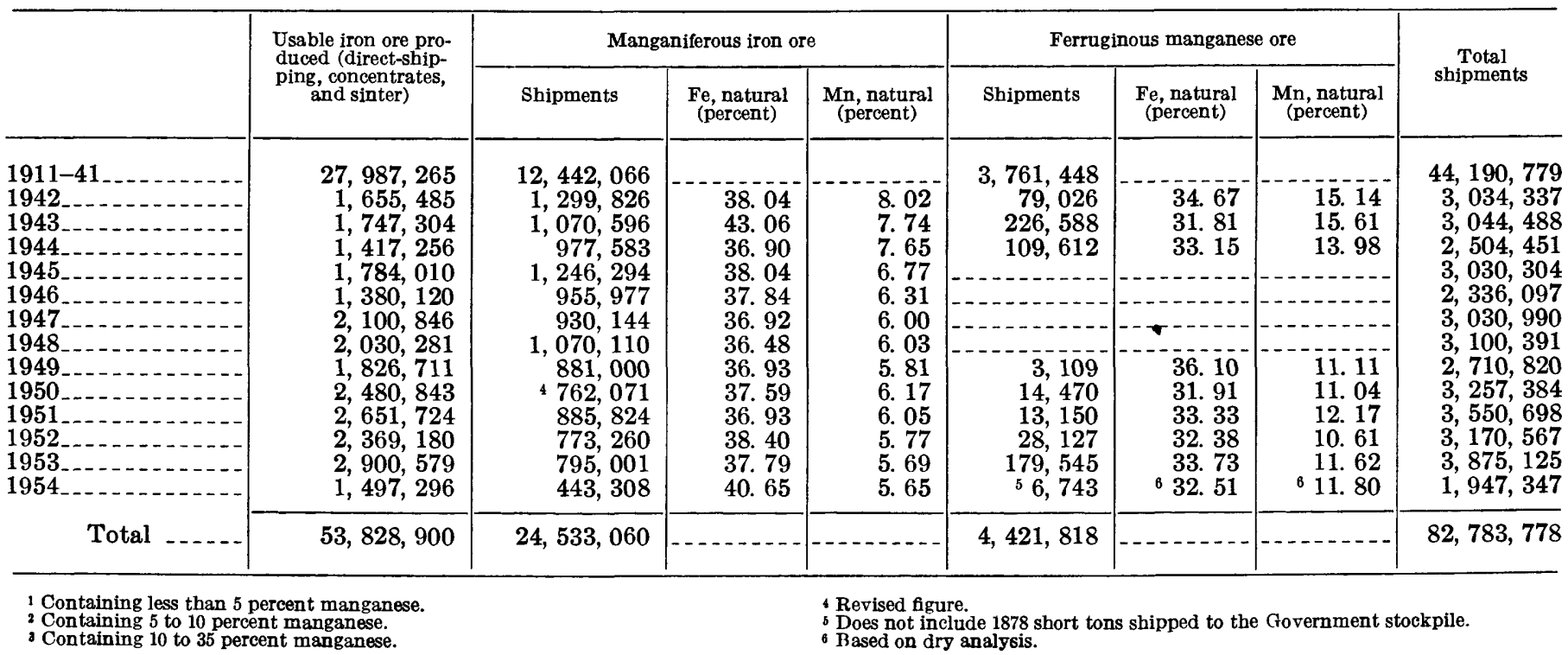


Lewis (1951) and Grout (Grout and Wolff, 1955) have emphasized the importance of the Cuyuna district as a potential source of manganese if foreign supplies are limited. Lewis has made an estimate of 500 million tons of material, containing more than 2 percent $\mathrm{Mn}$, none of which is considered part of a commercial reserve at present. This estimate is mostly based on open-pit mining, calculated to a mining depth of 150 feet, and includes considerable manganiferous slate in Aitkin County.

Details of the calculation of the reserve of low-grade manganese were not available, and no attempt was made to duplicate the calculation. It should be pointed out that the reserve figure includes all types of materials: unoxidized iron-formation, oxidized lean ore from both facies of the Trommald formation, and lean ferruginous manganiferous slate and argillite from Aitkin County. The part which is unoxidized iron-formation is assumed to be "carbonate slate," that is, iron-formation in which most of the iron and manganese are present as carbonates. This assumption is critical because the recovery of the manganese by practical methods known at present is contingent on the use of a process developed by the U.S. Bureau of Mines for treatment of ore containing manganese carbonate. Petrographic studies of the thin-bedded facies showed that the distribution of iron carbonate and manganese carbonate in the unoxidized rock is very irregular and that in many places relatively little carbonate is present. The iron occurs in silicates and in magnetite, and no separate manganese mineral could be identified; possibly the manganese is present as part of the silicates, especially stilpnomelane. The available data were insufficient to establish any regular pattern of the distribution of carbonate-bearing rock within the thin-bedded facies. The carbonatebearing rock does not persist along the strike, and in any particular place cannot be relied on to persist through any great stratigraphic thickness. So long as the recovery method depends on the occurrence of the manganese in carbonate rather than in a silicate, any reserve calculation pertaining to the thin-bedded facies must be supplemented by a careful mineralogic study. In most of the areas embracing large tonnages it is doubtful that enough representative cores were saved from exploratory drilling to make such a study possible without additional drilling.

As a tentative recommendation for exploration of this type, the minerals present in the unoxidized ironformation can probably be expected to be reasonably persistent for 1,000 feet along strike. Systematic drilling at that interval would provide the first information available on the real lateral persistence of critical minerals in the thin-bedded facies, and continued drilling may provide reasonable evidence for extension of the spacing to 2,000 feet or more.

\section{DESCRIPTION OF MINES}

In the following section, each mine in the district is described briefly. Each description includes the history of mining operations, the name of the company opening the mine and the company most recently operating it, the total production in long tons, and a summary of the geology of the deposit. No attempt has been made to detail the ownership of the properties or the very complex lease arrangements that are common in the district. The descriptive locations of the properties are strictly limited to those sixteenths of sections and lots in which actual mining operations were performed; where the leases also include several adjacent unmined properties, these are not listed. Production figures were taken from the Mining $\mathrm{Di}$ rectory of Minnesota (Wade and Alm, 1954, 1955), an annual publication of the University of Minnesota Mines and Experiment Station; this publication also lists all properties that include taxable ore reserves and the current owners and lessees. The method of describing the mines differs from the conventional treatment, inasmuch as a mine that is in effect a unit both geologically and in mining operation is described as such even though it may be divided by property lines. On the other hand, several distinctly different mines although operated together as a "group," such as the large Mahnomen group, are described separately.

The order in which the mines are described is roughly geographical, though strict adherence to any geographical system is very difficult. Mines in T. 47 N., Rs. 28 and 29 W. (pl. 2), are described generally east to west but are taken in counterclockwise order around the margin of the large Merritt mine-Rabbit Lake syncline beginning at the Kennedy mine and ending at the Joan No. 3 shaft. Mines in T. 46 N., R. 29 W. (pls. 3, 4), are considered successively southwestward from the North Yawkey to the Sagamore mine, but the order of individual mines is much less systematic.

\section{KENNEDY MINE}

The first ore shipped from the Cuyuna district was from the Kennedy mine (pl. 2, secs. 29 and 30 T. 47 N., R. 28 W.). Shaft sinking began in 1907; the stockpiling of ore started in 1908, awaiting completion of the railroad. The first shipments were made in 1911, the last in 1925. The mine was operated by RodgersBrown Ore Co. until 1923 and by Rodgers-Brown Ore Co. (Pickands Mather \& Co., Agents) in 1924 and 
$1925 ; 2,595,562$ tons of ore was produced. It was an underground mine, had at least three shafts in addition to the main hoisting shaft, and was worked by top slicing and caving.

The Kennedy mine is on a broad belt of Trommald formation where a series of close, though probably not isoclinal, folds has repeated the formation many times at the bedrock surface. Various rocks that are not iron-formation occurred in the workings, and some of these were believed by Harder and Johnston (1918, p. 119,161$)$ to have been chloritized intrusive rocks. By comparison with the area around the Mahnomen group of mines, which this area resembles structurally, it is reasonable to expect that narrow bands of the Mahnomen and Rabbit Lake formations may be found infolded in the Trommald formation if further exploration is undertaken and the rocks are carefully studied. It is impossible to ascertain from the drill logs whether the "diabase" in many holes is really igneous rock or perhaps unoxidized iron-formation, or to be sure what general type of rock is meant by "red schist," "green schist," and "carbonate."

The thin-bedded facies of the Trommald formation is relatively thick in this part of the district, probably 200 to 300 feet; and the thick-bedded facies is probably in excess of 100 feet thick. Most of the workings of the Kennedy mine were in the thin-bedded facies, and it is not known if any thick-bedded iron-formation was found in the mine. The underground geology has been described by Harder and Johnston (1918, p. 159-162). Part of their description (p. 160-162) follows:

Judging from secondary structures in different parts of the mine, it appears that the entire body of iron-bearing rock is a straight succession. The beds appear to be on the south limb of an anticline, the older rocks occurring along the northwest side of the belt. The iron-bearing rock consists mainly of ferruginous chert with local irregular bodies of iron ore. In places the ferruginous chert is hard and massive, while elsewhere it is partly disintegrated forming wash ore. With depth, the ferruginous chert grades into cherty and argillaceous ferrous carbonate and silicate rocks such as cherty and slaty iron carbonate, amphibole-magnetite rock, and magnetitic slate. These unoxidized phases are especially abundant in the deeper workings of the western and northwestern parts of the mine. Thus above the 210-foot level there is hardly a trace of ferrous rocks, the entire iron-bearing rock being oxidized, while on the 262-foot level the unoxidized phases are abundant. Ferruginous chert, however, is still abundant on the 262-foot level, especially directly beneath the ore bodies where downward circulation has probably been facilitated by the greater porosity of the material. The metamorphosed magnetitic phases of the original iron-bearing rock are more common in the western portion of the workings, the unaltered carbonate phases occurring in the central and northern parts. In the unoxidized parts of the iron-bearing formation in the lower levels, green chloritic schist occurs as it does in the upper levels, but its alteration to red hematitic schist is much less marked. Usually the green schist is in direct contact with the ferrous rocks, and locally it is somewhat difficult to distinguish underground between the argillaceous ferrous rocks and the green schist. In many parts of the mine the schist contains small disseminated crystals of carbonate, probably calcite. In the green chloritic schist these crystals are fresh and transparent, but in the red hematitic schist they are decomposed and form scattered white spots.

There is thus a general gradation in the Kennedy mine from ore, wash ore, ferruginous chert, and hematitic schist in the upper levels, to cherty and argillaceous iron carbonate, amphibole-magnetite rock, magnetitic slate, and green chloritic schist in the lower levels. The occurrence of the different rocks is necessarily somewhat irregular, green chloritic schist being fairly common in the upper levels and ferruginous chert being abundant in the lower levels; nevertheless the general change is very significant.

There are four main ore bodies at the Kennedy mine, which, although irregular, are roughly in the form of lenses parallel to the general trend of the rock layers. They are located in general along a line transverse to the bedding of the rock and have been designated, from northwest to southeast, the (1) north lens, (2) midway lens, (3) intermediate lens, and (4) south lens. The longer axis of each body is parallel to the bedding of the enclosing rocks. Little scattered lenses of ore are found between the main lenses and along their borders. The main shaft is located between the intermediate and south lenses. At the present time only the lenses north of the shaft are producing ore, but in the past considerable ore has been mined from the south lens.

The ore from the different lenses varies somewhat as regards texture and composition. The characteristic ore of the north lens is distinctly laminated, dark reddish to bluish hematite associated with more or less brownish, siliceous, hydrated hematite and limonite. The latter becomes more abundant in the lower levels. The laminated ore is mostly amorphous, but certain layers contain much crystalline hematite. The lamination is caused by the interlayering of ore of different colors, or by the interlayering of siliceous laminae or crystalline laminae with the common amorphous ore. The ore usually breaks along lamination planes, often yielding large slabs.

The principal ore of the midway lens is a soft, yellow to brown, ocherous limonite. Locally masses and fragments of hard, brown limonite occur in it. Bedding is very indistinct and in places wanting.

The intermediate and south lenses consist largely of ordinary hard, amorphous, dark brown limonite or hydrated hematite. Bedding is fairly distinct, but instead of the straight lamination shown by the north lens ore, the bedding planes are irregular and the ore is considerably fractured and crumpled. Much of the ore is of good grade, but much of it is siliceous, grading into ferruginous chert. There seems to be little regularity in the occurrence of the richer or leaner portions. They are irregularly intermixed. Even the boundary between the ore body and enclosing ferruginous chert is indefinite. Where the ore lies against hematitic schist, however, as southeast of the intermediate lens, the boundary is sharp.

Unfortunately, no maps were published to show the positions of the ore bodies and of the wallrocks that Harder and Johnston described. 
Zapffe disagreed on the general interpretation of the rocks as a "straight succession" and regarded the structure as "a series of folds having a distinct N.E. pitch" (Zapffe, 1928, p. 639).

The ore from the Kennedy mine was both hematitic and goethitic and was generally low in manganese, but some of the northernmost workings were in manganiferous ore.

\section{RABBIT LAKE MINE}

The Rabbit Lake mine (pl. 2, sec. 29, T. 47 N., R. $28 \mathrm{~W}$.) is the newest large ore body to be opened in the district. The ore body was known from earlier exploration but opening was delayed because of its being partly beneath the eastern lobe of Rabbit Lake. In 1945 a dike was constructed across the narrows separating the east and west lobes of the lake, and pumping was begun to drain the water from the eastern lobe. Soft mud in the vicinity of the ore body was removed by dredging in $1947-49$, and further stripping was by standard-methods using trucks and power shovels. The first ore was shipped in 1952, and the total shipped was 815,095 tons through 1955 . The mine was developed and is operated by Youngstown Mines Corp. (Pickands Mather \& Co., Agents).

The area stripped in the Rabbit Lake mine is entirely within the thin-bedded facies of the Trommald formation. In 1955 the pit exposed only one structure, a large asymmetrical syncline. The syncline is doubly plunging, $10^{\circ}$ or less, toward the center of the mine. Beds on the northwest side of the mine dip $45^{\circ}-80^{\circ} \mathrm{SE}$.; those on the southeast are uniformly close to vertical. Local drag folding and minor faulting were observed on the west side of the mine.

All the iron-formation in the mine is oxidized, and both brown and red oxides are present. The ore is not manganiferous. An irregular mass of red-brown titaniferous ferruginous rock, probably argillite, was observed in the west wall of the mine. Iron-formation along the southeast bank, stratigraphically the lowest beds seen in the mine, is very cherty and has locally been decomposed to a wash ore.

\section{NORTHLAND MINE}

The Northland shaft (pl. 2, sec. 20, T. 47 N., R. 28 W.) was sunk in 1918 by the Northern Minnesota Ore Co. shortly before the end of World War I, and development work was not completed. The only shipment of ore was 4,575 tons from the stockpile, in 1941.

The Northland shaft is near the upper contact of the Trommald formation on the northwest limb of a large southwest-plunging syncline. The mine is be- lieved to be on a southwest-plunging drag fold in which the lower contact of the Trommald formation appears much more folded than the upper. Only the thin-bedded facies of the iron-formation is present in this part of the district. Oxidized iron-formation in drill holes 800 feet west of the mine was brown. The log of a drill hole near the shaft reports hard diorite, but there is no other evidence of intrusion in the area. Similar descriptions in some other parts of the district refer to unoxidized iron-formation, and it is doubtful that diorite was found at this place.

\section{MILFORD MINE}

Shaft sinking was begun at the Milford mine (first called the Ida Mae; pl. 2, sec. 23 , T. 47 N., R. 29 W.) in 1917, and ore was shipped in 1918 and in most years through 1933. The mine was opened by the Cuyuna-Minneapolis Iron Co. and last operated by the Amherst Mining Co. A total of 1,266,172 tons of ore was produced.

Little geologic information regarding the Milford mine is available. The Trommald formation trends N. $80^{\circ}$ E., dips $50^{\circ}-60^{\circ}$ SE., and lies on the northwest flank of a major syncline (pl. 2). Only the thinbedded facies is present in this part of the district, and the Milford ores are brown and manganiferous; unoxidized iron-formation is abundant in the mine dump. The shaft was located in iron-formation. The mapped outline of the Trommald formation suggests that there may be drag folds in the mine area. Faults are reported by Wolff (Grout and Wolff, 1955, p. 76).

\section{PRESTON MINE}

The Preston shaft (pl. 2, sec. 27, T. 47 N., R. 29 W.) was sunk in 1918 by Coates and Tweed and later abandoned; no ore was mined. The property is now owned by the Inland Steel Co. The writer searched the vicinity of the old shaft for bedrock that might have been hoisted during development work but found none. Samples of fine drill cuttings indicate that the shaft was probably located in the thin-bedded facies of the Trommald formation.

\section{GLORIA MINE}

Shaft sinking in sec. 28 , T. 47 N., R. 29 W. (pl. 3) was begun in 1916 by E. J. W. Donahue, and ore was shipped in 1919 and 1920. Including shipments from the stockpile made in 1931, the mine produced only 2,074 tons. The mine was called the Donahue and the McKenzie before being renamed the Gloria in 1918. The idle mine is now owned by the Hanna Iron Ore Co. 
The only descriptions of the workings of the Gloria mine were given by Wolff (Grout and Wolff, 1955, p. 60) who said that a crosscut northwest from the shaft "encountered about 170 feet of the Upper Cherty member and some black manganiferous ore. A crosscut was driven southeast from the Gloria shaft through green slates, and into slaty brown manganiferous ore."

The shaft is believed to have been sunk near the middle or top of the thick-bedded facies of the Trommald formation.

\section{ALGOMA MINE}

Development work on the Algoma underground mine (pl. 3, sec. 33, T. 47 N., R. 29 W.) was begun in 1911 by the Iron Mountain Mining Co., and ore was first shipped in 1915; the mine, operated through 1920, is now idle, the last operators being the Onahman Iron Co. The mine was first called the Iron Mountain and then the Hoch. Including a stockpile shipment of 59 tons in 1931, the total production from the mine was 106,119 tons of ore, probably all ferruginous manganese ore. The ore was mined by top slicing and by overhand stoping and square setting.

The Algoma ore body was a series of four thin manganese-rich lenses parallel to the bedding of the enclosing iron-formation. The lenses were in the lower part of the thick-bedded facies of the Trommald formation on the southeast-dipping northwest limb of a major syncline. The iron-formation strikes about N. $50^{\circ}$ E. and dips $65^{\circ}-78^{\circ} \mathrm{SE}$. in the mine.

The ore lenses ranged in thickness from 4 to 30 feet; presumably thinner layers could not have been considered minable. The lenses were separated by ferruginous chert zones 4 to 35 feet thick and were mined for 300 to 400 feet along the strike and to the 160-foot level in depth. Harder and Johnston (1918, p. 138) visited the mine and described the ore:

The material varies in character in the different ore zones, as well as in different parts of the same zone. One zone consists mainly of ocherous, brown iron ore, speckled and blotched with impregnations of manganese ore. Others consist of uniformly black manganiferous iron ore, at some places soft and at others hard and siliceous. At one point a zone of manganiferous iron ore passes into high-grade iron ore along the strike. Thus there is considerable variation in the character as well as in the composition of the ore, and in order to maintain a uniform product, the ore from the different zones is mixed in mining.

Hard red granular chert or jasper from the cherty layers between the ore lenses can be found on the dumps near the old shaft.

\section{FERRO MINE}

The Ferro underground mine (pl. 3, sec. 32, T. 47 N., R. 29 W.) was opened in 1913 as the DuluthBrainerd mine by the Locker-Donahue Co., but was taken over by the Onahman Iron Co. and the name changed to the Ferro in 1915, before any ore was produced. Regular shipments were made from 1916 to 1921, and a stockpile shipment was made in 1931. Ore was mined by Butler Bros. in 1942-43, presumably through the Merritt mine, and a stockpile shipment was made in 1944. Total production 1916-44 was 181,307 tons of manganiferous ore. The mine is idle.

The Ferro ore body is in the bottom of a syncline that is part of a group of drag folds in the keel of a large northeast-plunging major syncline. The mine shaft was northwest of the drag fold axis in the thinbedded facies of the Trommald formation; the bottom of the shaft was in unoxidized quartz-silicatecarbonate iron-formation. The main crosscut at 149 feet extended southeast through unoxidized thinbedded iron-formation and through the main ore lens into the hanging wall, the black ferruginous cherty thick-bedded facies. The ore was mined from one distinct layer paralleling the bedding that was 40 to 80 feet thick, and in most places close to 45 feet thick. The layer trended about $\mathrm{N}$. $55^{\circ} \mathrm{E}$. and was concave to the southeast because of its position on the synclinal fold. The ore body was described by Harder and Johnston (1918, p. 136, 137) :

The dip of the bedding of the iron-bearing rocks is from about $65^{\circ}$ southeast to vertical, and this is also the range in dip of the ore body. The latter occupies a certain zone in the iron-bearing beds, and apparently represents a replacement of the original rock along this zone by oxides of manganese and iron, chiefly manganese. This is well shown by the fact that the ore occurs along joints and minor cracks, and penetrates from these for varying distances into the mass of the rock. Many little rectangular blocks of ore are found which, on being broken, present an interior of decomposed or partially replaced rock. The nature of the original rock is not known. The character of the rock bounding the ore body leads one to suppose that it probably consisted largely of chert, ferrous carbonate, and ferrous silicate with perhaps considerable manganese carbonate and silicate. The decomposed residue, which at present acts as a sort of matrix in which the ore is embedded and in which it forms replacements, is a dark red, siliceous material rich in iron and usually soft and porous. Associated with the ore are certain layers of epidote rock, the relations of which are not yet known.

The grade of the ore is variable. Masses of rich, finely crystalline pyrolusite occur locally, while elsewhere mixed manganese and iron oxides are found. The matrix of dark red material in which the ore occurs can not be separated from it in mining, so that the ore as shipped ranges between 20 and 30 per cent in metallic manganese and about the same in 
iron. It is one of the best grades of manganiferous iron ore shipped from the Cuyuna district at the present time.

The epidote rock mentioned may have been acmiterich rock, for Grout (1946a, p. 125) states that the acmite had been previously described as epidote. The stratigraphic position of the ore in the Ferro mine is about the same as the acmite rock in the University of. Minnesota drill hole 500 feet northeast of the Ferro property line.

\section{JOAN NO. 4 MINE}

Development work began on the Joan No. 4 underground mine (pl. 3, sec. 32, T. 47 N., R. 29 W.) in June 1917, and first shipments were made later that year by the Joan Mining Co. Shipments totaled 40,328 tons of manganiferous ore during 1917-20, and the mine has been idle since. Some ore was shipped from stockpiles in 1931; ore was mined by Butler Bros. in 1943, presumably through the Merritt mine, and stockpile shipments were made in 1944. Total ore shipped through 1944 was 59,430 tons. The Joan shaft is not shown on the accompanying maps because no accurate location could be found. The general geologic relations of the ore are doubtless the same as in the adjoining Ferro and Merritt mines.

\section{MERRITT MINE}

The Merritt mine (pl. 3, sec. 33, T. 47 N., R. 29 W.) was opened as an underground mine in 1916-17 by the Merritt Development Co. and produced ore intermittently from 1917 to 1943 . Ore from both Nos. 1 and 2 properties was mined through a shaft in the NW $1 / 4 \mathrm{SW} 1 / 4$. The mine was last operated by Butler Bros. (M. A. Hanna Co., Agents). Through 1955 the production figures of 603,612 tons from Merritt No. 1 and 369,355 tons from Merritt No. 2 include stockpile shipments by Butler Bros., 1944 49; small shipments from tailings piles made by Zontelli Bros., Inc., 1951-55; and probably do not include tailings shipments made to Manganese Chemical Corp., Riverton, Minn., 1952-56. Ore was mined by top slicing and caving and brought out of the mine through an inclined ore hoisting shaft. A large mill operated in conjunction with the mine was located in lot 6 , sec. 4, T. $46 \mathrm{~N}$., R. $29 \mathrm{~W}$, on the northwest shore of Menomin Lake; the tailing piles are at this place.

The Merritt ore body was in the tightly folded keel of a major northeast-plunging syncline. From the caved area at the surface it appears that most of the ore was on the crest of a small anticline in a series of tight drag folds in the major synclinal trough. The mine is in both the thin- and the thick-bedded facies of the Trommald formation, and it is believed that most of the ore was in, or close to, the facies transition. The lower part of the thin-bedded facies is not oxidized. The ore mined was red brown to black and richly manganiferous. Lean ore from this mine can be examined in large dumps.

\section{PONTIAC MINE}

The Pontiac mine shaft (pl. 3, sec. 34, T. 47 N., R. 29 W.) was sunk in 1918 by the Oneida Mines Co., but the mine was not ready to produce before the end of World War I, and it was abandoned. It was originally called the Clark mine.

\section{JOAN NO. 3 MINE}

A shaft for the Joan No. 3 mine (pl. 3) was sunk in sec. 34 , T. 47 N., R. 29 W. in $1916-17$ by the Joan Mining Co. No ore was produced, and the mine was abandoned.

\section{NORTH YAWKEY MINE}

The small North Yawkey open-pit mine (pl. 3, sec. 1, T. 46 N., R. 29 W.) was stripped by the Hanna Iron Ore Co. in 1953 and 1954. In 1954 and 1955, the ore shipped totaled 374,051 tons.

The North Yawkey mine is situated in a band of steeply dipping iron-formation on the northwest side of a major syncline. The iron-formation strikes N. $55^{\circ}$ E. and dips $55^{\circ}-75^{\circ}$ SE. No bedrock other than iron-formation is exposed in the mine.

The iron-formation in the North Yawkey mine is all thin-bedded facies of the Trommald formation. Most of the oxidized iron-formation is hematitic; along the west side of the mine, however, unoxidized iron-formation is exposed in the bank, and this is separated from the hematitic material by 50 to 100 feet of brown oxidized iron-formation and ore.

\section{MANUEL MINE}

Stripping for the Manuel mine (pl. 3, sec. 1, T. 46 N., R. 29 W.) was begun in 1951 by Zontelli Bros., Inc., and 736,677 tons of ore was shipped from 1952 through 1955. The mine is operated by Zontelli Division of Pittsburgh Pacific Co. and includes the properties called the South Yawkey, Manuel, and West Airport.

The Manuel mine is on the southeast limb of a major syncline. The exposure of Trommald formation is 350 to 450 feet wide, strikes N. $55^{\circ}$ E., and is overturned with dips from $60^{\circ} \mathrm{SE}$. to vertical. The Rabbit Lake formation is well exposed along the northwest side of the pit. About 10 feet of gray and red-brown laminated slate is stratigraphically above 
the iron-formation, and red-brown saprolite that shows no bedding occurs above the slate. The rock without bedding is probably the alteration product of a flow or massive tuff. Southeast of the Trommald formation a layer of chloritized and decomposed igneous rock is exposed in a small area in the mine. The sill-like intrusive mass is dull gray green and of medium grain and presumably was dioritic or gabbroic in composition. Drill holes south of the pit penetrated gray and brown sericitic slate of the Mahnomen formation and showed that the width of the bedrock exposure of the igneous rock separating the Mahnomen and Trommald formations is 200 to 400 feet.

The iron-formation in the Manuel mine is all oxidized thin-bedded facies of the Trommald formation. It is generally cherty and is oxidized to both hematitic and goethitic material. Concentric layering of iron oxide and silica of the liesegang type is very abundant in the southwest end of the mine, especially in the most cherty parts of the iron-formation. The layering transects the bedding.

\section{CROFT MINE}

The Croft mine (pl. 3, sec. 1, T. 46 N., R. 29 W.) was begun in 1914 by the Merrimac Mining Co. (John A. Savage \& Co.), and ore was shipped from 1916 to 1934. The present interests are Hanna Coal \& Ore Corp. The mine produced 1,770,669 tons of ore excluding that removed from the Meacham property. It was worked to a depth of 630 feet and is now inactive.

The Croft mine is situated in a belt of Trommald formation from 60 to 300 feet wide striking N. $55^{\circ} \mathrm{E}$. The iron-formation dips steeply southeast. Two dips determined from the contacts in drill holes were $60^{\circ}$ to $65^{\circ} \mathrm{SE}$.

The Rabbit Lake formation forms the northwest or structural footwall rock, and the shaft is in this formation; the southeast-dipping rocks are overturned, as the Rabbit Lake formation is the younger. The geology southeast of the main belt of Trommald formation is complex, and only limited information is available regarding it. The wallrocks are presumed to be chloritized and in part oxidized igneous rocks. Drill-hole logs describe the materials as diorite, intrusive, green rock, and variously colored schist. A layer of iron-formation occurs in this wallrock 400 to 600 feet to the southeast, and it is connected to the main belt by a diagonal segment. The two belts and the connecting segment appear to have formed by intrusion of the igneous rock forcibly parting the Trom- mald formation along various beds. The connection of the diagonal band of iron-formation with the main band is interpretive and is not positively established by drilling data. No connection of the southeast belt with other isolated belts that occur farther southwest is known.

The ore in the Croft mine was high-grade bessemer and nonbessemer low-manganese hematite. The drilling revealed no unoxidized iron-formation on the property. Mining was confined to the northwest belt of the Trommald formation.

\section{MEACHAM MINE}

The shaft for the Meacham underground mine (pl. 3, secs. 11 and 12, T. 46 N., R. 29 W.) was sunk in 1910 by Rodgers-Brown Ore Co., but no ore was shipped until 1916. Total shipments in 1916-34 were $1, \dot{3} 39,020$ tons. The $\mathrm{NW}^{1 / 4} \mathrm{NW} 1 / 4$ sec. 12 was worked as part of the Croft mine during 1929-31, and the 1932 and 1933 shipments were stockpiled ore from this operation. Ore in the northwestern part of the $\mathrm{NE} 1 / 4 \mathrm{NE} 1 / 4$ sec. 11 is now mined by open pit as a part of the Portsmouth mine. The ore body in the original Meacham is considered to be exhausted (Lake Superior Iron Ore Assoc., 1938, p. 273).

The thin-bedded facies of the Trommald formation occurs in three parallel bands on the Meacham properties, and ore has been mined from two. The first, a broad belt of iron-formation in which the Portsmouth mine is now located, cuts across the northwest corner of the NE1/4 NE1/4 sec. 11 . The Meacham mine is in the second or central belt, 100 to 250 feet wide, located 300 to 600 feet southeast of the first, and separated by an infolded mass of Rabbit Lake formation. The third belt is 300 to 700 feet southeast of the second and is 120 to $\mathbf{1 8 0}$ feet wide; the intervening rock is believed to be a generally concordant intrusive body, thoroughly chloritized. Scant information from exploration drilling indicates that chloritized igneous rock also occurs southeast of the third belt.

The second belt strikes N. $60^{\circ}$ E. and dips southeast. This is the northeast extension of the ironformation in the Armour No. 2 and the Thompson mines and is overturned. The width of the bedrock exposure narrows from 250 to 100 feet toward the northeast, and this narrowing is perhaps related to the crosscutting of the bedding by intrusion of the large igneous mass to the southeast. No unoxidized iron-formation was reported in the drilling in this belt. The Meacham mine produced brown iron ores and manganiferous iron ores.

The third belt of Trommald in the Meacham property is brown oxidized iron-formation. 


\section{THOMPSON MINE}

The Thompson mine (pl. 3, sec. 11, T. 46 N., R. 29 W.) was developed as an underground operation in 1911 and shipments began in 1912. Overburden stripping began in 1913 and shipments from an open pit were made during 1914-16. Subsequently, ore was mined by the milling (glory-hole) system and hoisted in the shaft; ore in the northern part of the $N W 1 / 4$ NE $1 / 4$ was removed by underground methods. The mine was operated by Inland Steel Co. and produced ore until 1920. Later, the open pit was filled with stripping from another mine, and the ore body in the northern part of the property was mined as part of the Portsmouth open pit, now operated by the Hanna Iron Ore Co.

The iron-formation and ore in the Thompson mine are divided into two main belts by a narrow infolded strip of Rabbit Lake formation; a third unmined belt occurs to the southeast, a continuation of the southeast belt in the Meacham property. The northern belt is described under the Portsmouth mine.

The second or central belt is an extension of the ore in the Armour No. 2 open pit to the southwest and the Meacham underground mine to the northeast. Geologic details of this mine were taken from the map printed by Harder and Johnston (1918, pl. 22). The iron-formation strikes N. $65^{\circ}$ E., and the overturned beds dip $40^{\circ}-80^{\circ}$ SE. Near the south edge of the mine the iron-formation is divided by a concordant layer of hematitic schist, the northeastward extension of the chlorite schist in the Armour No. 2 pit, and presumably likewise derived from alteration of an intrusive rock.

The iron-formation in the Thompson mine is entirely the thin-bedded facies of the Trommald formation, and it is all oxidized brown or red brown. Some of the iron-formation is cherty, and in part this chert is decomposed; the material, therefore, was mined and treated as a wash ore.

The Rabbit Lake formation between the old pit and the mine shaft was described by Harder and Johnston (1918, p. 149) as "light gray to dark gray or red siliceous and ferruginous argillite (or slate)." They further described a thin lens of ore interbedded in the argillite just northwest of the main ore body.

The third or southeast belt has been penetrated by several drill holes, and a few holes in adjacent wallrocks indicate that chloritized igneous rock occurs on both sides of the iron-formation.

\section{PORTSMOUTH MINE}

The Portsmouth mine is one of the largest open pits in the district; the pit has been formed by the combination of several smaller pits and underground mines: Portsmouth, SE1/4SE1/4 sec. 2; Wearne, SW1/4SE1/4 sec. 2; Osberg, SE1/4SW1/4 sec. 2; Chisholm-Williams, NW1/4NW1/4 sec. 11; Evergreen, NE $1 / 4 \mathrm{NW}^{1} / 4$ sec. 11 ; Healy, formerly part of Thompson, NW $1 / 4 \mathrm{NE}^{1} / 4$ sec. 11 ; and Meacham, NE1/4NE1/4 sec. 11 (pl. 3). Development of the Portsmouth ore body began with the northward crosscutting from the Thompson underground mine into the northern part of the NW $1 / 4$ NE $1 / 4$ sec. 11 in 1912 or 1913 . The Wearne mine, $\mathrm{SW} 1 / 4 \mathrm{SE} 1 / 4$ sec. 2 , was stripped as an open pit in 1916. From the Portsmouth mine $13,127,832$ tons were shipped through 1955 , exclusive of ore mined from the Thompson mine. The Portsmouth mine is now operated by the Hanna Iron Ore Co. Ore is moved from the mine on a 1,714-foot inclined conveyor belt and travels to a large mill made up of a washing plant and a sintering plant.

The Portsmouth mine is situated in a broad belt of folded iron-formation on the northwest limb of a syncline. Though the mine is as much as 1,200 feet wide, only ore and iron-formation are exposed in it. The strike of the contacts of the Trommald formation is N. $60^{\circ}-70^{\circ}$ E. Toward the south, at the west end of the mine, the folding is very intense (pl. 3) ; fold axes are closely spaced, and some of the folds are isoclinal. Toward the north the folds seem to be more open and the axes farther apart. The fold axes trend $\mathrm{N} .70^{\circ}-85^{\circ} \mathrm{E}$. at a noticeable small angle to the strike of the contacts; this strike suggests a general eastward plunge of the folds in accordance with the plunge indicated by the larger structural pattern; that is, near the southwest end of a doubly plunging syncline.

Fold axes in the Portsmouth mine do not have a uniform plunge, but they are inclined either northeast or southwest at angles as much as $45^{\circ}$ (pl. 3). The generalized northeast plunge is deduced from the strike of fold axes compared with the strike of the formational contacts. The directions of fold plunge were studied carefully, and it was found that reversals were generally systematic and indicated a group of gentle northwest-trending cross folds. Similar cross folds may be present in many parts of the district, but the subtle detail necessary to map them was obtainable only in the excellent exposures in this mine.

All the iron-formation in the Portsmouth mine is the thin-bedded facies of the Trommald formation. Unoxidized iron-formation is exposed in many parts of the mine, probably representing many different stratigraphic positions within the formation, and there is great variety in the minerals contained at the differ- 
ent exposures. Large irregular masses of lean ironformation associated with the ore have been left in the mine and greatly aided geologic mapping. No systematic variation in the lithology of the iron-formation was found. Titaniferous argillaceous layers in the iron-formation are more common here than in any other mine in the district. One large lenticular mass, in the $N E 1 / 4 N W 1 / 4$ sec. 11 , is presumed to be a type of intercalated titaniferous ferruginous argillite ( $\mathrm{pl}$. 3 ). It is a chlorite schist (table 6, sample 1045), and slabs of iron-formation as much as a foot long are included in it within a few feet from the contacts.

The Portsmouth mine produces both brown and red-brown iron ores and manganiferous iron ores. A general line of separation between the brown and the red-brown ores is very close to the section line between secs. 2 and 11. Ores north of the section line are mostly brown, except for a narrow north-trending belt along the east end of the pit; ores south of the section line are mostly red brown, but of course there are many exceptions to this generalization. Deepest mining was near or slightly southeast of the long axis of the pit, especially in the southwestern part of the $\mathrm{SE} 1 / 4 \mathrm{SE} 1 / 4 \mathrm{sec} .2$ where mining went to more than 300 feet below the surface. Unoxidized ironformation is abundantly associated with brown ore on the northwest side of the mine where the depth of oxidation generally decreases northward. In the part of the mine in sec. 11, oxidation has been more general, and the bottom of the oxidized iron-formation has not been reached. Brown ore and unoxidized iron-formation are less common. The only exposure of a transition from unoxidized thin-bedded iron-formation to red-brown oxidized iron-formation observed in the district occurs on the west line of the $\mathrm{NW} 1 / 4 \mathrm{NE} 1 / 4$ sec. 11 , about 350 feet south of the northwest corner.

In the $\mathrm{SE} 1 / 4 \mathrm{SE} 1 / 4$ sec. 2 , small pockets of brown ore cut across the strike of the beds and are between walls of unoxidized iron-formation.

The Portsmouth mine has recently been extended northeastward into the W1/2 SW $1 / 4$ sec. 1 and farther northward into the $\mathrm{SW} 1 / 4 \mathrm{SE} 1 / 4$ sec. 2 than is shown on the accompanying maps.

\section{ARMOUR NO. 2 MINES}

Armour No. 2 mines include an underground mine and an open pit (pl. 3, sec. 11, T. 46 N., R. 29 W.). The underground mine is served by an old shaft in the SW $1 / 4 \mathrm{NW}^{1 / 4}$ and a new shaft in the $\mathrm{SE} 1 / 4 \mathrm{NW}^{1 / 4}$. The open pit, at present inactive, is in the SE $1 / 4 \mathrm{NW}^{1 / 4}$. Work on the Armour No. 2 underground mine was begun in 1910, and the first ore was shipped in 1912.
The mine was opened by Rodgers-Brown Ore Co. and is now operated by Inland Steel Co. The old shaft was not used for hoisting ore during recent years, all ore having been hauled to the Armour No. 1 shaft. The underground ore has been mined by top slicing and stoping methods. The underground and open pit produced $6,255,364$ tons through 1955 .

The ores of the Armour No. 2 mines have been developed in two northeastward-merging belts (pls. $7,8)$. A relatively narrow strip along the north edge of the $\mathrm{SW}^{1 / 4} \mathrm{NW} 1 / 4$ pinches to the east as the ironformation-schist contact and the property line converge; the strip is only a small part of a wide belt of iron-formation in the properties to the north. The southeast belt extends northeastward across the SW1/4 $\mathrm{NW} 1 / 4$, where it is about 140 feet wide, broadens greatly, joins with the northwest belt, and splits again into two bands in the $\mathrm{SE} 1 / 4 \mathrm{NW} 1 / 4$. A third belt occurs southeast of the open-pit mine and was exposed in the pit before slumping of the banks. It is separated from the ore body by a layer of chlorite schist. The belts of iron-formation all dip to the southeast; some of the beds are known to be right side up and some overturned, but for much of the area the stratigraphic tops are not known.

The old Armour No. 2 shaft is near the center of the $\mathrm{SW} 1 / 4 \mathrm{NW}^{1} / 4$ in the large mass of schist that separates the northwest and the southeast ore bodies. The schist was examined on the 168-foot level from the iron-formation contact near the northwest ore body to 70 feet southeast of the shaft beyond which the workings were unsafe. The northwest edge of the schist is oxidized to a red-brown "paint rock" for 25 feet from the iron-formation contact. The schist was exposed on the 168-foot level in many places in a distance of 400 feet along the haulageway and was believed to be all metamorphosed sedimentary rock. There is no evidence that part of this mass of chlorite schist is igneous as there is at the Armour No. 1 mine to the west. Harder and Johnston (1918, p. 147) reported that "a few lenses of iron-bearing formation" within the chlorite schist were disclosed by drilling.

The northwest ore body is along the edge of a wide belt of iron-formation that is exposed for 1,300 feet north of the chlorite-schist and iron-formation contact. The ore body is the northeast extension of the Armour No. 1 ore body and is similar in width and depth and in its relationship to the schist. The extent, if any, beyond the property line to the north is not known.

The southeast ore body is much more complex. The structural data recorded by Harder and Johnston 
suggest that at the southwest end the iron-formation dips $40^{\circ}-80^{\circ} \mathrm{SE}$. and shows no evidence of folding. The ore body extended southwestward into the Ironton and Bonnie Belle mines. This part of the ore body was worked to a depth of 348 feet, the iron-formation largely having been converted to ore at the southwest end. Ferruginous chert is increasingly abundant south of the ore toward the northeast. The ironformation is reported to be bounded by chlorite schist on both the northwest and southeast sides. The chlorite schist is altered to a hematitic material near the iron-formation contact.

In the SE1/4NW1/4 the southeast belt of iron-formation is much wider and the chlorite schist near the old shaft has narrowed and disappeared; the southeast and northwest belts are joined. Most of the details of the geology known in the $\mathrm{SE} 1 / 4 \mathrm{NW}^{1 / 4}$ were obtained from the Armour No. 2 open pit. On the northwest side of the mine, a narrow tightly compressed syncline of Rabbit Lake formation begins about midway between the ends of the mine and plunges to the northeast. This infolded mass, less than 100 feet wide at this exposure, broadens northeastward to more than 1,500 feet and is one of the major structural features in the district. The Rabbit Lake formation seen here is gray laminated tuff and black pyritiferous argillite, in part alunitic. The iron-formation is overturned and dips generally $55^{\circ}$ $60^{\circ} \mathrm{S}$. Along the southeast bank of the mine, a concordant layer of gray-green chloritized intrusive body about 50 feet thick is enclosed in the iron-formation. This layer is known to extend northeastward into the Thompson property, where it pinches out; but its southwest extension beyond the bank of the pit is not known, and its junction with the chlorite schist farther southeast is only presumed. The width of the iron-formation southeast of the chloritized intrusive rock is not known because the southeast contact has not been found. Presumably, the width of the iron-formation and the type of wallrock are the same in the property as to the east where the ironformation southeast of the intrusive rock is perhaps 120 feet wide and is bounded on the southeast by gray and green schist.

All the iron-formation in the Armour No. 2 mine is the thin-bedded facies of the Trommald formation, and it is all oxidized. In the northwest ore body and in most of the southeast ore body, the ore is mixed brown and red brown, and both iron ore and manganiferous iron ore occur in each ore body. At the southwest end the southeast ore body is darkred iron ore, in part bessemer grade. The iron-formation in the open pit is very cherty, especially along the northwest bank. In much of the cherty ironformation the iron has formed small $1 / 8$ to $1 / 2$ inch concretionary ellipsoids and, where the chert is softened, makes an excellent wash ore.

\section{ARMOUR NO. 1 MINE}

Development of the Armour No. 1 mine as an underground operation (pls. 3, 7, 8, sec. 10, T. 46 N., R. 29 W.) began in 1910 and ore shipments were made in 1912 and 1913. Stripping began in 1915 and shipments from the open pit were made the same year. Development was by Rodgers-Brown Ore Co., but the mine has been operated by Inland Steel Co. since 1915. After a period of operation as an open pit, underground mining was resumed and has continued to the present. The deepest mining was on the 800-foot level, and the top-slicing method was used. The mine produced $6,271,672$ tons of red-brown and brown iron and manganiferous iron ores through 1955.

The shaft, the main haulageways, and some exploratory workings have been in various kinds of chlorite schist that form the south wallrock to the Armour No. 1 ore body. The contact relations of the chlorite schist and the iron-formation are not simple (pl. 8, sections 10-13). The Trommald formation is in a series of relatively open folds of moderate size, roughly 100 to 200 feet separating any two anticlinal axes. The axial planes strike about N. $70^{\circ}$ E. and $\operatorname{dip} 65^{\circ}-80^{\circ} \mathrm{SE}$., and the beds on the fold limbs dip from $30^{\circ} \mathrm{SE}$. and $\mathrm{NW}$. to nearly vertical. The general attitude of any particular bed as a result of the folding is that of horizontality, which is analogous to the gently folded, nearly horizontal structures on the south side of the Pennington mine ( $p$. 75 ) and in contrast to the steeply dipping beds on the north side of the Pennington mine. The gently folded generally horizontal sequence is abruptly cut off on the southeast side of the mine by the large mass of chlorite schist that is in part chloritized igneous rock and in part metamorphosed sedimentary rock, probably Rabbit Lake formation. The proportions of each are unknown. Hematitic schist, an oxidized form of the chlorite schist, appeared on the original bedrock surface as a lens or tongue 700 feet long and as much as 60 feet wide separated from the main schist mass by a belt of iron-formation 50 to 140 feet wide. The separating iron-formation, largely converted to ore and now mined out, narrowed with depth and disappeared within several hundred feet; the schist lens then joined the main mass of wallrock. Iron-formation was also found to the south within the main schist mass by three holes drilled north- 
east of the No. 1 shaft (pl. 3), two of which show on plate 8 , section 11 . The relation of this iron-formation to the ore-bearing beds farther north is not known, and no record that mine workings penetrated this mass of iron-formation has been found.

Samples of chloritized schistose quartz diorite were collected near the Armour No. 1 shaft on the 600-foot level. It is not known, however, if the chlorite schist forming the greater part of the south wallrock of the Armour No. 1 ore body is derived from chloritized and sheared quartz diorite or metamorphosed sedimentary and perhaps some volcanic rock in the Rabbit Lake formation. Chlorite schist collected on the 168-foot level of the Armour No. 2 mine was interpreted to be metamorphosed Rabbit Lake formation.

All the iron-formation in the mine is oxidized, and the chlorite schist is also oxidized for several feet or tens of feet from the iron-formation contact. The ore body closely followed the chlorite schist contact and tended to cut across the bedding. The main ore body was a tabular mass ranging roughly from 30 to 100 feet in thickness, and generally thinning with depth, and extending the full width of the property and the full depth of mining. The iron-formation and chlorite schist contact dips steeply southeastward near the surface and more gently with depth. The sides of the ore body dip in the same way; but the correspondence is not exact, and lean ore occurs between the ore and schist in some parts of the mine. Ore also occupied much of the belt of iron-formation between the partly separated schist and the main hanging-wall schist. Exploration has not found the lower limit of the ore.

\section{IRONTON MINE}

The Ironton mine (pl. 3, sec. 11, T. 46 N., R. 29 W.) was developed in 1912 and 1913 as the CuyunaDuluth mine by the Cuyuna-Duluth Iron Co. Later it was operated by Inland Steel Co. as a part of the Armour No. 2 mine; top-slicing and caving methods of mining were used. It is currently inactive. The first ore was shipped in 1913, and the last from stockpiles in 1933. Shipments totaled 968,166 tons.

Most of the geologic information on this mine was taken from Harder and Johnston $(1918$, p. 146). The ore body closely resembles the adjacent part of the Armour No. 2 ore body of which it is a southwest extension. The thin-bedded facies of the Trommald formation strikes N. $60^{\circ}$ E. and dips $35^{\circ}-60^{\circ} \mathrm{SE}$. It is bounded above and below by gray-green schist that is hematitic near the contacts. The schist on the northwest side in the Armour No. 2 property is partly, or perhaps entirely, of sedimentary origin, but the origin of that on the southeast side is not known. The schist on the southeast side of the Armour No. 2 pit is chloritized igneous rock; similar rock occurs 1,350 feet east and somewhat south of the old Ironton shaft.

The ore in the Ironton mine was red and bluish-red hematite of high grade. It contained little manganese. No unoxidized iron-formation was reported in the mine or in drilling records.

\section{BONNIE BELLE MINE}

Originally developed as the Liberty mine in 1918 by the Liberty Mining Co., the Bonnie Belle (pl. 3, sec. 10, T. 46 N., R. 29 N.) produced 225,706 tons of ore during the years $1917-25$ as an underground operation. The mine was operated during 1923-25 by Inland Steel Co. in conjunction with the Ironton mine. It is now considered exhausted (Wade and Alm, 1955, p. 65).

The Bonnie Belle ore body was a southwest extension of the Armour No. 2 and Ironton ore bodies. Like the Ironton ore body, it was enclosed by chlorite schist of uncertain origin, and drilling records seem to indicate that the iron-formation pinches out in depth (pl. 8, section 10). The iron-formation, presumably all the thin-bedded facies of the Trommald formation, occurs in a belt 80 to 100 feet wide crossing the property about N. $70^{\circ} \mathrm{E}$. The shaft was located south of the iron-formation in green schist, but penetrated iron-formation a short distance below the bedrock surface. North and east of the shaft the bedrock exposure of the iron-formation is interrupted by 100 to 150 feet of schist; exploration drilling records show, however, that the iron-formation was continuous beneath this schist capping. Thiel (1924b) reported a basic igneous rock here. No unoxidized ironformation was reported from this property. The mine produced high-grade red nonbessemer iron ore.

\section{PENNINGTON MINE}

Stripping was begun at the Pennington mine (pl. 3, sec. 10 , T. 46 N., R. 29 W.) in 1913 , and ore was shipped that year by the Tod-Stambaugh Co. It is now operated by Rhude and Fryberger, who have begun underground mining from the bottom of the open pit. A small complex ore-dressing plant is run in conjunction with the mine. The mine produced 3,058 ,183 tons of ore through 1955 .

The geology of the Pennington mine is complex, and several problems remain unsolved. Many of the general features and the problems are the same as in the Feigh (p. 75-76) and the Armour No. 1 mines, 
and the geology of these mines is closely interrelated.

The Trommald formation strikes N. $70^{\circ}-85^{\circ} \mathrm{E}$. and dips southeastward, steeply on the north bank and gently on the south bank (pls. 3, 8). Drag folds are common in the iron-formation and plunge southwestward, except one on the north bank that plunges to the northeast. A fracture zone that parallels the strike of the beds and dips southward on the north side of the pit is believed to be related to fracturing in the Feigh mine and to be part of one large strike fault.

As in the Feigh mine, the fracture zone in the Pennington extends upward from a large mass of wallrock that broadens with depth. This mass is not bedded, but it generally resembles the bedded schist exposed on the south bank of the mine. The origin of this schist is not known, but it is tentatively classified as igneous.

Most of the north bank of the Pennington mine exposes Trommald formation, which is known to extend 50 to 150 feet northwest of the mine. A complex mass of Rabbit Lake formation and perhaps other rocks is exposed on the north bank near the center of the mine, but the geologic relations of this mass are not known. It lies above and close to the shear zone described above. The dominant rock is black and gray laminated slate; gray schist without bedding and amygdaloidal or porphyritic schist are also abundant. The relations are confused by many small shears. The general sequence from south to north probably was: Trommald formation, 5 to 10 feet of gray laminated slate, sheared gray schist, amygdaloidal or porphyritic schist, and knotted schist as much as perhaps 20 feet, and more than 20 feet of black slate. The black slate is in part alunitic and in part very pyritic, the pyrite decomposing under present weathering. The elliptical masses in the knotted schist are 1 to $10 \mathrm{~mm}$ long and are largely muscovite. The laminated slate, unbedded schist, and black slate sequence has been found in several other places in the district at the base of the Rabbit Lake formation.

A considerable thickness, perhaps 50 feet, of bedded biotite-chlorite schist conformably overlies the iron-formation along the south bank of the mine and dips gently southward. Both schist and iron-formation are folded; the folds plunge generally southwestward, though a few northeastward plunges were also observed. The folds are open; the axial plane cleavage is nearly vertical (fig. 10). The schist contains abundant apatite and locally abundant pyrite cubes as much as 1 inch across. There can be little doubt that this rock conformably overlies the Trommald forma- tion and is the metamorphosed equivalent of the basal part of the Rabbit Lake formation. The Rabbit Lake formation is metamorphosed into the chlorite zone on the north side and into the biotite zone on the south side of this mine, 200 to 300 feet away; the reason for the difference in metamorphic grade on the north and south banks of the mine is not known. The distance of separation may have been greater at the time of metamorphism, for the suspected faulting probably occurred later and thrust the rocks on the south side of the mine northwestward.

The biotite-chlorite schist extends westward into the East Feigh pit, which may be considered a small westward extension of the Pennington mine.

The iron-formation of the East Feigh and Pennington mines is all thin bedded and is all oxidized. Much of that which remains in the mine is very cherty. The oxides are hematite and goethite; hematite is dominant in the deeper east end of the mine. Some of the richest ore in the mine formed an envelope about a steeply dipping lens of chlorite schist in the center of the mine. Shearing extends upward from this lens of schist roughly paralleling the bedding of the ironformation. Rich hematitic iron ores associated with the schist have cindery and massive textures.

\section{FEIGH MINE}

The Feigh mine (pl. 3, sec. 10, T. 46 N., R. 29 W.) was opened as an underground mine by the Jefferson Iron Mining Co. in 1917. The history of the leases on the property is very complex. It was partly stripped about 1937 and has been extensively operated as an open-pit mine since that time. The present operator is Hanna Coal \& Ore Corp. The mine shipments were 3,230,380 tons of ore through 1955 .

The East Feigh pit was stripped separately; it is described under the Pennington mine with which it is now continuous.

The Trommald formation is exposed in a band as much as 700 feet wide that strikes about N. $65^{\circ}$ E. and in general dips steeply to the southeast. Part of the iron-formation is highly distorted, and this mine exposes some of the most complex geology seen in the district. The general structure is believed to be an anticlinal fold, the axis overturned to the northwest. The fold axis is probably broken along a sheared zone (pls. $3,7,8$ ), and perhaps the shear is a thrust fault of major proportions.

The Rabbit Lake formation exposed on the northwest side of the Feigh mine is black argillite and slate dipping $70^{\circ}-80^{\circ} \mathrm{SE}$. The wallrock on the southeast side of the mine is all chlorite schist that is bedded, contains 1-inch layers of gray-green chert, dips $40^{\circ}-$ 
$60^{\circ} \mathrm{SE}$., and is considered to be Rabbit Lake formation also. At the northeast end of the mine a large lens of schist strikes parallel to the length of the pit and dips steeply southeastward; it is tentatively considered an intrusive along the faulted crest of the large anticline, but it may also be schist from the metamorphosed Rabbit Lake formation faulted into its present place. The lens is known from drilling to increase in width for a considerable distance below the bottom of the mine as shown on plate 8 , section 2 . Drilling has also disclosed Mahnomen formation in one hole deep within the heart of the anticline (pl. 8, section 1). There is abundant shearing and brecciation that may be evidence of faulting in a zone that parallels the length of the pit and nearly midway between the sides. The zone is alined roughly with the lens of schist at the northeast end of the mine and with a severely folded belt in the South Hillcrest mine to the southwest.

In the northeast end of the mine are numerous thin layers or lenses of chlorite schist conformably interlayered with the iron-formation. It is not clear whether these were argillaceous lenses in the original sediment, fault slivers of Rabbit Lake formation, or intensely sheared intrusives. Near the top of the Trommald formation at the southwest corner of the mine there are argillaceous lenses, a few feet thick, containing abundant tourmaline needles. Some tourmaline needles $1 \mathrm{~cm}$ long are in the bottom of the Rabbit Lake formation at this place.

The iron-formation is largely oxidized, but there is abundant unoxidized material in the south-central part of the mine. Oxidation has yielded both red-brown and brown iron ore, and the mine has produced some wash ore. There are local occurrences of manganiferous iron ore.

\section{SOUTH HIILCREST MINE}

The Hillcrest mine (pl. 3, sec. 9, T. 46 N., R. 29 W.) was stripped as an open pit in 1915 by the Hill Mines Co. Later development of the North Hillcrest property made the "South" designation necessary. It is now operated by the Hanna Coal and Ore Corp. Shipments through 1955 totaled 1,906,756 tons.

In general, the thin-bedded facies of the Trommald formation in the South Hillcrest mine dips steeply southeastward with considerable tight folding on the south side of the mine. The principal structure probably is a tight, almost isoclinal, anticline slightly southeast of the center of the mine, and the wallrocks on both sides are the Rabbit Lake formation in normal stratigraphic position. The fold axes plunge $5^{\circ}-30^{\circ}$ NE. Brown and red-brown oxidized iron- formation is present in the mine; no unoxidized ironformation was observed. Iron ore and manganiferous iron ore were mined.

The rock in the northwest wall is gray and redbrown laminated and tuffaceous slate. The southeast wall is a gray chlorite schist that has, perhaps, a trace of bedding. Locally it contains large pyrite crystals. Stratification in both rocks dips southeastward parallel with the Trommald formation contacts. The chlorite schist is interpreted as the somewhat more metamorphosed equivalent of the basal part of the Rabbit Lake formation that is exposed on the northwest bank of the mine.

Near the top of the Trommald formation on the southeast side of the mine are several light-gray siliceous lenses, 2 to 5 feet thick and 20 to 50 feet long, containing abundant tourmaline in disseminated needles and clusters of crystals. The origin of these rocks is not known.

About 500 feet east of the west boundary NE1/4 SE $1 / 4$ in the northwest bank of the pit, a 4 -foot iron-rich layer was observed 20 feet above the base of the Rabbit Lake formation. This is one of the few places in the district where iron-rich rock was found in the lowermost 500 feet of the Rabbit Lake formation.

\section{HUNTINGTON MINE}

The Huntington mine (pl. 3, sec. 9, T. 46 N., R. 29 W.) was opened as an underground operation by the Whitmarsh Mining Co. in 1918, and ore was produced in 1922 and 1924. Later operated by the Hanna Iron Ore Co., the ore body was stripped and worked as an open pit, first separately, and now in conjunction with the South Hillcrest mine. Through 1955, shipments totaled 773,926 tons of ore.

The Trommald formation in the Huntington mine strikes about $\mathrm{N}$. $70^{\circ} \mathrm{E}$., dips steeply to the southeast, and is overturned with the top on the northwest side. The iron-formation has been explored to great depth, and it is all thin bedded and all oxidized. Both redbrown and brown oxidized iron-formation are present, and parts of the ore body were manganiferous.

The northwest wall contains an assemblage of the rocks generally found at the base of the Rabbit Lake formation. Laminated and tuffaceous slates occurred at the base in contact with the iron-formation at the east and west ends of the mine; near the center, part of the slate was black and carbonaceous. Near the west end abundant black slate was exposed about 40 to 60 feet stratigraphically from the basal contact of the Rabbit Lake formation. At the east end a 30foot layer of relatively unbedded and sheared and decomposed rock is intercalated about 40 feet from the 
base. This layer is probably metamorphosed and saprolitized tuff. The south wall is biotite-chlorite schist, similar to schist on the south banks of the mines to the northeast, but entirely lacking bedding. Because it seems to be continuous with the bedded schist at the Feigh mine and because it resembles the metasedimentary schists microscopically, it is tentatively proposed that this schist is a metamorphosed part of the Rabbit Lake formation. The position of the schist requires that the iron-formation be isoclinally folded into an anticline, though no folding was observed, or that the schist be faulted against the iron-formation, perhaps in a continuation of the fault suspected in the Feigh mine to the northeast. The Trommald formation is known to be present south of the schist mass, and the schist is perhaps no more than 200 feet thick; the Mahnomen formation is known to occur south of this second band of iron-formation. Obviously, much more information about the structural geology in this immediate area is desirable.

\section{MARTIN MINE}

The Martin mine (pl. 3, secs. 9 and 16, T. 46 N., R. 29 W.) was opened in 1917 and 1918 as an underground mine by the Whitmarsh Mining Co., who shipped 1,421 tons of ore in 1918. It was later operated as an open pit by Evergreen Mines Co. during 1944-46. Stockpile shipments were made by the Hanna Iron Ore Co. in 1930 and 1933 and by Zontelli Bros., Inc., during 1949-53. Total shipments through 1953 have been 311,782 tons. Snyder Mining Co. is the recent lessee.

The Martin mine was flooded at the time of this study; so no detailed examination of the geology could be made. Most of the geologic information was obtained from examination of the drill-hole samples. The Trommald formation strikes N. $10^{\circ}-30^{\circ}$ E. and dips $20^{\circ}-60^{\circ} \mathrm{SE}$. The beds are probably all overturned with the tops northwest, and the strike and dip differ considerably in various parts of the mine. Wallrocks on both sides of the iron-formation were cut by many of the drill holes and were probably exposed in the open pit. Wolff (Grout and Wolff, 1955, p. 73) reported a basic sill on the north side of the mine. The south wallrock is for the most part slate and silty slate of the Mahnomen formation. There is no quartzite. The Trommald formation is entirely thin bedded and oxidized; the iron minerals are both red and brown. The structure of the iron-formation may be complex, although from the dip of the bedding in drill cores, it seems to be simple. The decrease in width of the bedrock exposure of the iron-formation toward the northeast coupled with the divergence at depth of the upper and lower contacts of the ironformation cannot be explained. Numerous lenses of argillaceous rock are interlayered in the iron-formation. Lenses of gray and brown schistose rock several tens of feet thick that may be metamorphosed sills, or perhaps masses of Rabbit Lake formation that have been faulted into their present position, are on the southeast side near the Mahnomen formation contact. The rock resembles the Rabbit Lake formation on the southeast side of the Huntington-Pennington group of mines. The wallrock on the north side of the mine. is mostly black slate and argillite, but there is also a massive rock in some of the cores that may be of igneous origin. The massive rock is thought to be the same as that found near the base of the Rabbit Lake formation at the Mallen mine and at many other places. It is probably at least partly volcanic, and may have been a lava flow or a tuffaceous sediment.

\section{MANGAN NO. 2 MINE}

The Mangan No. 2 mine (pl. 3, sec. 10, T. 46 N., R. 29 W.), now operated as part of the Mahnomen group of mines, may be considered a separate ore body. It was originally opened in 1916 as a separate underground mine by the Mangan Iron and Steel Co., it was later stripped as an open pit. Ore in the northwest corner of the property has been mined as part of the Mahnomen No. 1 ore body described below. The property, including the corner mined as part of the Mahnomen No. 1 mine, has produced 2,152,745 tons. The operating company is Cuyuna Ore Co. (Pickands Mather \& Co., Agent).

The Mangan No. 2 mine is at the northeast end of a large syncline that extends more than 3 miles southwest to the Rowe mine. The open pit is situated entirely on the north side of the syncline, but a drift from the old underground workings extended to the south side and provided the structural data shown on plate 8 , section 12 . The ores occur in the thin-bedded facies of the Trommald formation. The Mahnomen formation, exposed in the Mahnomen No. 1 mine in the northwestern part of the Mangan No. 2 property, is penetrated by drill holes a short distance below the bottom of the Mangan mine along the north bank. The Trommald formation is drag folded in several places in the open pit; these drag folds plunge $30^{\circ}$ $35^{\circ} \mathrm{SW}$. A 5 -foot bed of thick-bedded chert is expcsed in the southwest corner of the mine high on the bank and near the top of the formation. This bed pinches out eastward and is believed to be the last southeastward trace in this part of the district of the thick-bedded facies that thickens to the west and north. The Rabbit Lake formation is well exposed 
along the south side of the mine at the east end, where it may be seen in contact with the underlying Trommald formation. The iron-formation, which is very cherty and locally somewhat pyritic near the upper contact, is overlain by 2.5 feet of red-brown and gray to almost black laminated slate, which is, in turn, succeeded by dark-gray and brown-spotted schist, siliceous slate, and granular slates that are presumed to have been tuffs. The contacts are nearly vertical; local slight overturning to the southeast, very infrequently observed in the district, was found in a few places here. The infolded Rabbit Lake formation is narrow, and the southwest plunge is believed to cause it to disappear eastward near the east edge of section 10. Drill-hole data are too scant to show just where the disappearance occurs. The iron-formation that is south of the shallow syncline of Rabbit Lake formation is just north of the Armour No. 1 ore body. It has been penetrated by one exploratory drift mentioned above and several drill holes, but has not been mined.

The ores of the Mangan No. 2 mine are red brown and brown. Unoxidized iron-formation, especially laminated silicate-magnetite, is abundant in the east half of the mine associated with brown ores. Excellent exposures show the relation of gnarled ore to unoxidized iron-formation. The mine has produced both iron ore and manganiferous iron ore.

\section{MAHNOMEN NO. 1 MINE}

The large Mahnomen No. 1 mine (pl. 3, sec. 10, T. $46 \mathrm{~N}$., R. $29 \mathrm{~W}$.) is the deepest open pit in the district. Stripping was started in 1915 by Mahnomen Mining Co. (Clement K. Quinn \& Co.), and first shipments were in 1916. The mine has been operated in conjunction with several mines collectively called the Mahnomen group. The only production figure available is $9,724,446$ tons for the group, including the Mahnomen Nos. 1, 2, 3, and 4, and part of the SultanaHopkins mine (in all, the $\mathrm{S} 1 / 2 \mathrm{SE} 1 / 4$ sec. 3 ; and $\mathrm{NW} 1 / 4 \mathrm{NE} 1 / 4$ and $\mathrm{N}_{1} / 2 \mathrm{NW}^{1} / 4$ sec. 10 ). The mine is now operated by the Cuyuna Ore Co. (Pickands Mather \& Co., Agents). The pit is about 350 feet deep, and truck haulage has been replaced by a 1,490-foot threestage conveyor belt. A large concentrating plant in the $\mathrm{NE} 1 / 4$ sec. 3 is operated in conjunction with the Mahnomen Group of mines.

The Mahnomen No. 1 mine is situated on a closely folded southwest-plunging syncline, and mining has extended into the flanks of adjacent synclines. The main synclinal fold axis which strikes N. $70^{\circ}$ E. and plunges $10^{\circ}-15^{\circ} \mathrm{SW}$. is exposed in the southwest end of the mine. The adjacent anticlines are also observ- able in the mine; the Mahnomen formation is well exposed where folded upward in these structures (fig. 20 ). The anticlines plunge $35^{\circ}-50^{\circ} \mathrm{SW}$., and the slate of the Mahnomen formation is very intensely drag folded.

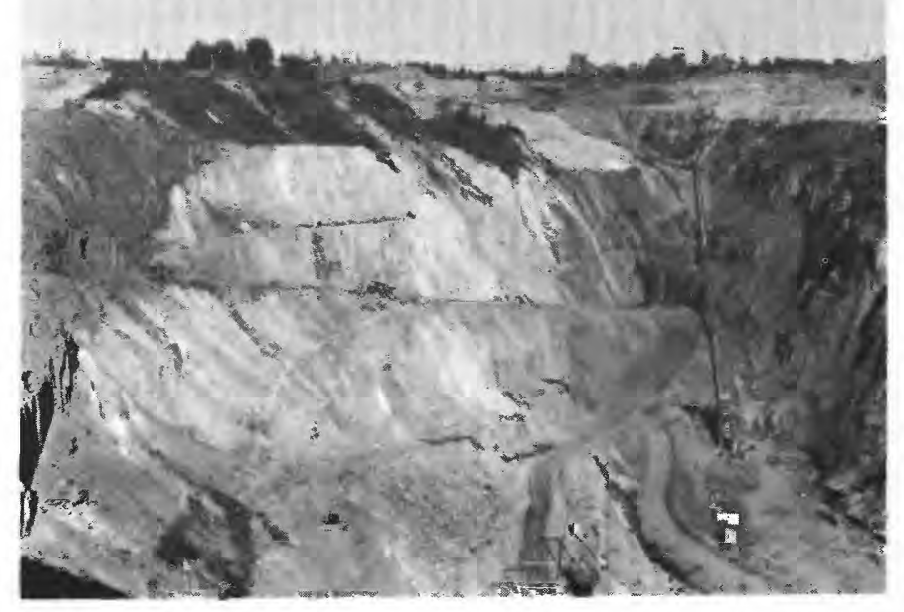

Figury 20.-The Mahnomen No. 1 mine, looking northeast. The light-colored rock in the foreground is the Mahnomen formation in a large anticline; the darker Trommald formation overlies it on both sides. Part of the three-stage conveyor belt system for hoisting ore is seen on the far bank of the mine.

The belt of the Mahnomen formation in the anticline on the northwest bank of the mine is one of the type exposures of this formation; it is 1,500 feet long and as much as 350 feet wide. The rock is largely laminated slate and one bed of coarse quartzite. The Mahnomen formation is also exposed in the southeast bank of the mine in a narrower more tightly folded anticline whose exposed width is little more than 100 feet. This anticline is considerably more overturned than the one in the northwest bank of the mine, and the top is at a lower elevation; most of the length of Mahnomen formation presently exposed, 1,000 feet, was covered by iron-formation before mining. Much iron-formation and ore have been mined from the Mangan No. 2 pit southeast of this anticlinal band of Mahnomen formation.

All the iron-formation in the mine is the thinbedded facies of the Trommald formation, representing a stratigraphic thickness of 200 to 250 feet. The basal 4 to 30 feet of the iron-formation is notably cherty on both sides of the mine, and the chert is distinctly thin bedded. Beds of very magnetic unoxidized iron-formation were found near the base of the Trommald formation. The top of the formation, where the thick-bedded facies would be if present, is not found in the mine. 
Ores in the Mahnomen No. 1 mine were red-brown hematite at the deep southwest end grading to brown ores at the shallower northeast end. The brown ores have been removed to the level where considerable unoxidized iron-formation is associated with them, and the ores seem to grade downward into the unoxidized rock. Northeast of the mine, in the continuation of the same syncline in the SW1/4 SW1/4 sec. 2, unoxidized iron-formation extends to the bedrock surface.

Both iron ores and manganiferous iron ores have been produced from the mine. The best manganiferous ores were mined during the early years of operation and are believed to have come from near the center of the ore body, indicating that they may have been generally confined to stratigraphically higher beds which have been entirely removed.

\section{MAHNOMEN NO. 3 MINE}

The Mahnomen No. 3 mine (pl. 3, sec. 10, T. 46 N., R. 29 W.) was opened and is operated by the Cuyuna Ore Co. (Pickands Mather \& Co., Agents). The ore production is included in the figures for the Mahnomen Group given under the Mahnomen No. 1 mine.

The Mahnomen No. 3 mine is situated in a southeast-dipping belt of iron-formation on the northwest limb of a large syncline. The structure of the ironformation is simple; it strikes N. $75^{\circ} \mathrm{E}$. and dips southeast $55^{\circ}$ to vertical. There are minor east and southeast-plunging drag folds at several places.

Sericitic slate and interlayered quartzite of the Mahnomen formation are very well exposed for about 1,000 feet along the northwest bank of the mine, especially along the approach road. The contact with the Trommald formation parallels the length of the mine and is well exposed. The base of the iron-formation is a layer of clean unbedded chert, 2 to 5 feet thick, that has generally altered to soft white sandy material. Most of the mine is in the thin-bedded facies of the Trommald formation, but in the southwest end of the mine the thick-bedded facies is also exposed for about 400 feet along the south bank. Probably about 100 feet of stratigraphic thickness of the top of the thick-bedded facies is unexposed and lies to the south of the Mahnomen No. 3 mine.

The ore in the mine is brown, and rests on a very irregular surface of unoxidized iron-formation, especially in the northeastern part of the mine. Many exposures of partly oxidized, probably nontronitic iron-formation, can be seen here. Very local hematitic oxidation is found across the southwest end of the mine and in a small area on the northwest side near the northeast end. The ore is manganiferous.

\section{HILLCREST EXTENSION MINE}

The Hillcrest Extension mine (pl. 3, sec. 9, T. 46 N., R. $29 \mathrm{~W}$.) is a small open pit stripped in 1954 by the Hanna Coal \& Ore Corp. The production is included in the figure for the Alstead-North Hillcrest mine.

The Hillcrest Extension mine is located on the northwest limb of a large syncline. The iron-formation strikes N. $65^{\circ} \mathrm{E}$. and dips $75^{\circ} \mathrm{SE}$. to vertical. Along the southeast side of the mine the dip flattens, and an open syncline is exposed near the southeast bank. This fold is presumed to be part of a drag-fold pair. The drag folds may cause the bedrock exposure of iron-formation south of the mine to be wider than is shown on the maps, but no drill-hole data were available in that area.

Both thick- and thin-bedded facies of the Trommald formation occur in the mine. The base of the Trommald formation is a 2- to 4 -foot chert bed generally altered to soft sandy material. The thinbedded facies is 80 to 100 feet thick, and the transition zone to typical thick-bedded facies is perhaps 30 feet thick. The thick-bedded facies is repeated by the synclinal fold, and probably only a few tens of feet of the bottom of this unit are represented; most of the thick-bedded facies lie to the south and are not exposed. The cherty beds are as much as 20 inches thick. The northwest bank of the mine is the underlying Mahnomen formation, which consists of brown and gray slate and layers of brown quartzite.

Nearly all the iron-formation in the Hillcrest Extension mine is hematitic. Brown oxidized iron-formation was observed in a small area at the northeast end near the Mahnomen formation contact, mostly hidden by the access road. No unoxidized iron-formation .was seen.

\section{MAHNOMEN NO. 4 MINE}

The Mahnomen No. 4 mine (pl. 3, sec. 3) was stripped and operated by the Cuyuna Ore Co. (Pickands Mather \& Co., Agents). It includes part of the area worked by the Sultana underground mine. Work on the Sultana mine (first called Cuyuna-Sultana) was begun in 1914 and ore was shipped in 1916. Production for the entire $\mathrm{S} 1 / 2 \mathrm{SE} 1 / 4$ sec. 3 is included in the figures for the Mahnomen group (see Mahnomen No. 1 mine).

The Mahnomen No. 4 mine is a small pit in a southwest-plunging syncline entirely within the thin-bedded facies of the Trommald formation. Iron-formation along the southeast side of the mine is believed to be close to the base of the Trommald formation, and beds in the center of the syncline at the southwest 
end of the mine are close to the top of the thin-bedded facies. A narrow northwest-trending zone of redbrown oxidized iron-formation cuts across the southwest end of the mine; the rest of the pit is in brown oxidized and unoxidized iron-formation. Gnarled textures are abundant in the brown ore. Unoxidized iron-formation occurs on both sides of the pit, and is silicate-magnetite rich and silicate rich. The mine has produced dominantly manganiferous iron ore.

\section{SULTANA-HOPKINS MINE}

The Sultana-Hopkins open-pit mine (pl. 3, sec. 3) includes areas that were mined underground as the Sultana and the Hopkins mines. The mine is now operated by Cuyuna Ore Co. (Pickands Mather \& Co., Agents). Production for all the SW $1 / 4 \mathrm{SE}^{1} / 4$ is included in figures for the Mahnomen group. The $\mathrm{N} 1 / 2 \mathrm{SE} 1 / 4$ or Hopkins property produced 614,973 tons of ore through 1955.

The Sultana-Hopkins mine is in a broad area of folded iron-formation. The main ore body occupied a syncline trending $\mathrm{N} .70^{\circ} \mathrm{E}$, and a subsidiary ore body extending northwest from the southwest end of the main trough cuts across a gentle anticline and syncline. The syncline in the main ore body plunges $10^{\circ}-25^{\circ} \mathrm{SW}$. Iron-formation exposed in the sides and bottom of the main or old part of the mine is all thin bedded, except at the southwest end where the central part of the syncline contains many thick chert beds representing a transition zone and the lowermost part of the thick-bedded facies. It can be seen that before mining the thick-bedded facies extended several hundred feet northeastward in the center of the pit where the rock is now removed. In the new northwest section of the mine, thin-bedded iron-formation is interbedded with thick chert beds; this interbedding indicates the stratigraphic zone of transition between the two facies which at this place seems to be somewhat thicker than the normal 10 to 30 feet. Granules and oolitic textures are visible in the cherty layers. Most of the oxidized iron-formation is brown, and gnarled ore occurs in many places. Unoxidized iron-formation is abundant on the north side of the mine and also on the south side at the northeast end. Magnetite, silicates, and siderite are each abundant at different places. The oxidized iron-formation at the southwest end of the main trough is red brown. The mine has produced manganiferous iron and iron ores. Regarding manganiferous ores in the Sultana underground mine, probably in the general area now removed by mining near the southwest end of the open pit, Harder and Johnston (1918, p. 156) described manganese-rich nodules formed by replacement of soft limonitic clay in which the nodules were embedded.

\section{LOUISE MINES}

The Louise underground mine (pl. 3, sec. 3) was opened as the Cuyuna-Mille Lacs mine in 1911 by the Cuyuna Mille Lacs Iron Co. and produced the first manganiferous ore to be shipped from the district, which was sent to Ashland, Wis., in September 1912 (Himrod, 1940, p. 54). An open pit was developed in addition to the underground mine in 1948 by the present operator, the Hanna Coal and Ore Corp. The underground mine has been idle since 1943. Total production for both parts of the mine was $4,018,243$ tons of ore through 1955 .

The Louise mine is located in an area where the iron-formation is in several parallel folds trending N. $60^{\circ}-70^{\circ}$ E. The folds plunge gently both northeast and southwest. Only the thin-bedded facies of the Trommald formation is exposed in the open pit, but both facies are present in the underground workings.

The underground mine has not been accessible recently, but has been well described by others. Harder and Johnston (1918, p. 152) described the north ore body near the old Cuyuna-Mille Lacs shaft in the $\mathrm{SE} 1 / 4 \mathrm{SW} 1 / 4$ :

The Cuyuna-Mille Lacs north ore body occurs along the crest of an anticline which strikes approximately northeastsouthwest. The north limb of the anticline near the ore body has a steep dip northwest, but away from the ore body the beds are overturned, and have a steep dip to the southeast. The dip is fairly low near the ore body, but is higher toward the southeast. The ore body appears to occupy a somewhat indefinite stratigraphic horizon, but its position along the crest of the anticline and its continuation downward along the axial plane suggests that in part, at least, the ore body is a replacement of a fractured zone.

This north ore body was continuous with the Mangan No. 1 underground ore body, and both were located in the thick chert beds of the stratigraphically higher thick-bedded facies. The south ore body consisted of several ore masses and lenses in and near the syncline passing near the center of the $\mathrm{SE} 1 / 4 \mathrm{SW} 1 / 4$. In describing the ore from the mine, Harder and Johnston said that the character of the ore in both ore bodies varied considerably:

Locally bodies of rich black manganese ore occur, but the general run of material is a medium soft to hard black or brownish manganiferous iron ore which varies in manganese content from place to place. The rich manganese ore as a rule is finely crystalline pyrolusite; some is fairly hard and compact and some is soft and friable. Dense, hard, black psilomelane is also of frequent occurrence. 
Exploration crosscuts were extended south and northwest from the Louise shaft in lot 7, and the structures shown therein (Grout and Wolff, 1955, p. 64) correspond with those mapped by Leith (unpub. data) in the SE1/4 SW $1 / 4$ and in the Arko mine by the writer.

The Louise open pit is on a group of folds some of which extend into the Mahnomen No. 2 mine (see below) and southeast of the folds in the Louise underground workings. Two anticlines and two synclines were observed in the mine. Sericitic slate and interbedded quartzite of the Mahnomen formation are exposed in a narrow belt in the crest of an anticline along the northwest side of the mine. All other rocks present belong to the Trommald formation. Both red-brown and brown ores are found in the mine, and unoxidized iron-formation is locally abundant. The iron-formation is oxidized red brown in a zone extending across the deepest part of the mine from the southeast corner and widening toward the northwest side. The iron-formation at the northeast end is brown, and most of the south bank of the mine consists of brown oxidized iron-formation and unoxidized magnetite-silicate iron-formation. Manganiferous iron ore and iron ore were found in the mine.

\section{MAHNOMEN NO. 2 MINE}

The Mahnomen No. 2 open pit (pl. 3, sec. 10) was stripped by the Cuyuna Ore Co. (Pickands Mather \& Co., Agents). Production is shown as part of the Mahnomen group, under the Mahnomen No. 1 mine.

The Mahnomen No. 2 mine is located in a shallow synclinal fold of iron-formation trending N. $70^{\circ} \mathrm{E}$. The syncline is continuous southwestward into the North Hillcrest and northeastward into the Louise open-pit mines. Beds on the northwest side of the syncline dip $50^{\circ}-80^{\circ} \mathrm{SE}$.; beds on the southeast side $\operatorname{dip} 60^{\circ} \mathrm{NW}$. to vertical and at one place were slightly overturned.

The iron-formation is the lowermost 100 to 150 feet of the Trommald formation and is entirely of the thin-bedded facies. The ore is mostly brown, and the outlines of the ore are very irregular. Red-brown hematitic zones cross the ore in several places along groups of joints perpendicular to the axis of folding. Unoxidized iron-formation is abundant in large masses, particularly one that is 250 feet long on the southeast side and extends across the pit nearly to the northwest bank. The unoxidized iron-formation as well as the ore is cut by many quartz veins and quartz-stilpnomelane veins.

\section{ARKO MINE}

The Arko mine (pl. 3, sec. 9) was first opened as an underground mine by the Arko Mining Co. in 1916 who shipped a small amount of ore through 1920 . Later, about 1938, the mine was stripped and shipments through 1948 totaled 419,510 tons. Production through 1955 is given as part of a group of mines under the description of the Alstead-North Hillcrest mine. The mine is now operated by the Hanna Coal and Ore Corp.

The Arko mine is in a broad fold of iron-formation. A conspicuous syncline extending the length of the mine and a less conspicuous anticline constitute a drag-fold pair on the southeast flank of the major syncline beneath Menomin Lake. The drag fold has caused the considerable width of the iron-formation at the bedrock surface.

Only the Trommald formation is exposed in the Arko mine and both facies may be seen unusually well. The mine may be described in two parts that are distinctly different geologically.

The northeast end of the mine is in an ore body entirely within the thick-bedded facies that occupies the center of a very tight northeast-plunging synclinal fold. The mined area is about 800 feet long and 100 to 200 feet wide and trends N. $75^{\circ}$ E. The syncline is tight, the northwest side dipping $30^{\circ}-35^{\circ} \mathrm{SE}$. and the southeast side $35^{\circ} \mathrm{NW}$. to vertical but in part overturned. The thick-bedded iron-formation is very cherty with beds as much as several feet thick; the rest of the iron-formation is hard and siliceous.

In contrast, the southwest end of the mine is in an ore body almost entirely in the thin-bedded facies. The folding is open and relatively gentle, and the ore body is oriented at an angle of $70^{\circ}$ to the strike of the beds and the fold axes. The main syncline of the northeast end of the mine is generally continuous to the southwest where it becomes very broad. To the northwest the axis of an open anticline strikes N. $50^{\circ}$ E. across the corner of the mine. Both folds are believed to die out within 500 to 2,000 feet west of the mine, where the iron-formation is a simple northwestdipping fold limb. Dips of the beds in the southwest part of the mine range from horizontal to vertical, and strikes roughly parallel the fold axes.

The southwest ore body is probably controlled by the abundant joints that strike roughly normal to the fold axes. The deepest part of the mine is largely in redbrown ore, and brown ore and unoxidized iron-formation are very abundant around the banks of the mine. Most and perhaps all of the ore that was taken from both parts of the Arko mine was manganiferous. 


\section{ALSTEAD-NORTH HILLCREST MINE}

The Alstead and North Hillcrest open-pit mines (pl. 3, sec. 9) are now considered a unit and part of a group that includes the Arko and Hillcrest Extension pits, herein described separately. The North Hillerest mine was opened in 1928 and the Alstead in 1929. The Alstead, North Hillcrest, Hillcrest Extension, and Arko mines together produced 3,270,489 tons of ore through 1955. The group of mines is operated by the Hanna Coal and Ore Corp.

The Alstead-North Hillcrest mine is in two distinct ore bodies. The main ore body occupies a shallow, somewhat undulating, synclinal trough of Trommald formation extending from the SE $1 / 4 \mathrm{NW}^{1} / 4$ northeastward to the southeast half of the $\mathrm{NE} 1 / 4 \mathrm{NE} 1 / 4$, and thence into sec. 10 and the Mahnomen No. 2 mine. The second ore body, the so-called South Alstead, is in the northwest flank of a major syncline-that same fold limb in which the Hillcrest Extension and Mahnomen No. 3 mines are situated.

The Alstead-North Hillcrest syncline may be generally regarded as a simple syncline in which the gentle plunge of the fold axis reverses at several places along the length of the mine. Detailed structural mapping shows that the same fold axis does not continue the full length of the mine but is offset twice by horizontal distances of 150 and 200 feet. The general trend of the synclines is N. $65^{\circ} \mathrm{E}$., and some of the axial planes of the folds are gently overturned toward the northwest. In the South Alstead section of the mine, the iron-formation strikes No. $75^{\circ} \mathrm{E}$. and dips $30^{\circ}-75^{\circ} \mathrm{SE}$. At the extreme southwest end of the mine the belt of Mahnomen formation in the anticlinal fold separating the main syncline from the south ore body plunges gently southwestward, and the basal beds of the Trommald formation connect the ore bodies at the bedrock surface.

The Mahnomen formation was observed in several places along both sides of the main syncline, in a large stripped area between the north and south ore bodies and along the northwest edge of the iron-formation in the south ore body. The Mahnomen formation is largely sericitic argillite and slate; locally, especially near the southwest end, sandy argillite and quartzite or sandstone are interbedded.

The iron-formation includes both thin- and thickbedded facies of the Trommald formation toward the west end of the mine and in the south ore body and only the thin-bedded facies in the North Hillcrest part of the pit. It is probable that some of the thickbedded facies was present in the North Hillcrest before mining and that it was confined to the center of the syncline which has been removed by mining. Certain inaccessible beds in the south bank of the north ore body near the east edge of the $\mathrm{SW}^{1} / 4 \mathrm{NE}^{1} / 4$ were believed to be thick bedded, but they could not be checked.

The lowermost 2 to 10 feet of the Trommald formation is a single bed of lean chert, pale green and hard where unaltered and soft, white, and "sandy" where decomposed. Paul W. Zimmer (oral communication) reported that part of the sandy grains were minute doubly terminated quartz crystals. The thin-bedded facies increases in total thickness from perhaps 50 to 70 feet at the southwest end of the mine to more than 100 feet at the east line of section 9 . The unoxidized phase is found at several places. It is of varied composition, from the almost pure quartz rock of the basal bed to laminated quartz-carbonate and quartz-minnesotaite-stilpnomelane rock a few feet or tens of feet higher in the section. Exposures are too sparse to determine the relations of these mineralogic types. Only the base of the thick-bedded facies is seen in the mine: in a small area at the extreme southwest end of the syncline where only a transitional lithology is represented and in excellent exposures in the south ore body where the transition and the base of the facies may be traced for 1,000 feet.

A great variety of ore and of ore-to-iron-formation relations exist in this mine. Both red-brown and brown ores are found; red-brown ore is much more abundant and was dominant in the two deeper parts of the syncline. Brown ore made up most of the shallow parts of the ore bodies, particularly near the northeast end of the syncline, and graded downward and laterally into unoxidized iron-formation. Near the northeast end, where the ore is irregular in outline and relatively shallow, the iron-formation has been cut by numerous coarse quartz veins as much as 1 foot wide, some of which contain abundant stilpnomelane. Red-brown oxides have formed along certain cross joints, and perhaps these were related to the formation of the adjacent brown ores. Both iron ores and manganiferous iron ores have been produced in the mine.

\section{MANGAN NO. 1 MINES}

Two mines are included here, the recently operated Mangan No. 1 or Mangan-Stai open pit and the inactive Mangan No. 1 underground mine (pl. 3, sec. 3). Work on the underground mine was begun in 1915, and ore was shipped in 1916 by the Mangan Iron and Steel Co. The mine was operated until 1920 and again in 1928; stockpile shipments were made in 1938. The property had perhaps as many as four shafts, all 
now abandoned, and the underground workings presumably connected with those of the Hopkins mine. The open pit was stripped by the Hanna Coal and Ore Corp. in 1949; and Zontelli Bros., Inc. took over operation of the open pit in 1953. Total production from lot 6 and the Joan or Mangan-Joan open pit in lot 5 was 662,938 tons of ore through 1955 . An additional 1,943 tons of ore was mined from beneath the former bed of Menomin Lake adjacent to lot 5 .

The ore body in the underground mine was south of the Mangan No. 1 shaft and was a northeast extension of the north ore body in the Louise (CuyunaMille Lacs) mine. The mine was richly manganiferous. Workings near the shaft shown at the east edge of the property may have been in ore, but no information about them was available.

The Mangan No. 1 pit is a small but deep mine close to the edge of Menomin Lake from which it is protected by a dike. The mine is in generally very cherty iron-formation that is very tightly folded into several anticlines and synclines plunging $25^{\circ}-45^{\circ} \mathrm{SW}$. The iron-formation is the thick-bedded facies of the Trommald formation, except for a small patch of thin-bedded iron-formation at the north end of the mine, which is probably part of the transition to the lower facies. As at the Joan No. 1 mine, the thick-bedded facies is in two subfacies, the straightand the wavy-bedded (not shown on pl. 3). The older strata, most conspicuous in the northeast half of the mine, are straight bedded, and are several feet thick. Ore in the wavy-bedded subfacies occurs in the southwest half of the pit, where beds are probably not more than 10 inches thick and are generally less. The bedding is much crenulated, possibly in part by the folding, but the beds of this subfacies are crenulated and wavy where there is no drag folding present. The cherty layers in this subfacies have locally decomposed and form wash ores.

The youngest beds in the Mangan No. 1 open pit, which are near the centers of the synclines exposed in the southwest bank, are very near the top of the Trommald formation, and further stripping on this bank will reveal the base of the Rabbit Lake formation in a short distance. The thin-bedded facies underlies the area to the east and plunges southwestward beneath the mine. The drilling to the east has indicated that a large part of the facies is unoxidized. Anomalous magnetic compass deflections along the east side of the Mangan No. 1 open pit suggest that the unoxidized thin-bedded facies is present at a shallow depth, for the thick-bedded facies does not ordinarily contain enough magnetite to produce such anomalous compass readings.

\section{JOAN NO. 1 MINES}

Two mines are described here: the old Joan No. 1 underground mine that is entirely within the SW1/4 NE $1 / 4$ or Joan property and the recently opened Joan or Mangan-Joan pit that extends from the Joan property southwestward into lot 5, the Mangan property (pl. 3). The Joan No. 1 shaft was begun in 1916, and 5,338 tons of manganiferous ores was shipped during 1917-19 by the Joan Mining Co. Harder and Johnston (1918, p. 157) reported that:

The outlines of the ore body are irregular, and development work has not yet been carried far enough to determine the extent of the ore. It appears to be a band about 12 feet wide following a generally northerly direction.

Parts of the underground workings have been intersected by the open pit.

The Joan open pit was stripped in 1949 by the Hanna Coal and Ore Corp., and it has been operated by Zontelli Bros., Inc., since 1951. The SW1/4NE1/4 sec. 3, including both the underground and the openpit mines, produced 651,692 tons of ore through 1955; production from lot 5 is included under the Mangan No. 1 mine. The Joan open pit is on the southeast flank of a major southwest-plunging syncline and is less than 1,000 feet from the keel of the syncline. The beds in the mine dip generally northwestward, but they are complicated by drag folds in several places. The visible iron-formation includes the thinbedded facies and two subfacies of the thick-bedded facies, which are described below; there are also excellent exposures of the base of the Rabbit Lake formation. The stratigraphic section that can be seen probably exceeds 400 feet in thickness and includes all the Trommald formation, except perhaps 100 feet or less at the base.

The thin-bedded facies is exposed in a belt as much as 100 feet wide, extending 1,000 feet along the southeast side of the mine. An unusual feature of the facies at this place is the abundance of coarse quartz sand in thin laminae in the lowermost beds exposed. Much of the sandy iron-formation is unoxidized and is very magnetic. Above the unoxidized thin-bedded facies is oxidized thin-bedded lean iron-formation and ore that grades upward into the thick-bedded facies through a transition zone which is about 50 feet thick. The lower part of the thick-bedded facies is about 130 feet thick, and is made up of straight chert beds 1 to 6 feet thick separated by thinly laminated layers. The upper part, 100 feet thick, is wavy bedded and includes much wash ore. The contact between the subfacies is relatively sharp. Along the northwest bank of the mine the Rabbit Lake formation is exposed for 500 feet where it overlies the iron- 
formation. It is composed of 20 feet of laminated argillite and interbedded tuff overlain by spotted-gray unbedded slate that is probably a metamorphosed tuff or flow. Manganiferous iron ore and iron ore were produced from the Joan mine. The manganiferous ore occurred in a belt extending about 30 feet on each side of the transition between the facies. The underground mine was probably confined to the transition zone.

\section{MAROCO MINE}

The Maroco mine (pl. 3, secs. 4 and 5, T. 46 N., R. $29 \mathrm{~W}$.) is the largest in the district, producing ore exclusively from the thick-bedded facies of the Trommald formation. It was first opened as the Adbar underground mine by the Adbar Development Co. in 1915 and 1916, but no ore was shipped. The mine was leased to the Marquette Ore Co., who stripped the ore body in $1920^{-}$and 1921 and shipped the first ore in 1921. The mine is now operated by the Hanna Coal and Ore Corp. It had produced 3,463,482 tons through 1955; the Trojan property in sec. 5, operated as part of the Maroco mine, had produced 102,932 tons through 1948.

The Maroco mine is on a spectacular group of southwest-plunging drag folds on the northwest flank of a major syncline. The drag folds plunge $20^{\circ}$ to $45^{\circ}$. Two small faults that offset the upper contact of the Trommald formation strike N. $55^{\circ}-60^{\circ} \mathrm{W}$. and dip away from each other; data on these faults were kindly supplied by Paul Zimmer, of the M. A. Hanna Co. Excellent extensive exposures of the Mahnomen, Trommald, and Rabbit Lake formations occur in the mine. The Mahnomen formation is largely quartzitic, but there is much interbedded red-brown slate. The Trommald formation is entirely of the thick-bedded facies, largely wavy bedded, very cherty, and relatively thin-85 feet thick at the west end of the mine and 130 feet at the east end. The material mined is treated in a washing plant at the east end of the mine. The ore consists of alternating layers of iron oxides and crumbly white chert or quartz. The iron oxides, either hematite or goethite, are in wavy, irregular layers 1 to 6 inches thick, separated by layers of chert 1 to 12 inches thick. The ore of this mine generally contains very little manganese, but small pockets of very rich manganese ore have been found. One was in the southeast corner of lot 3 near the base of the Trommald formation, and fractures filled with cryptomelane and pyrolusite extend into the underlying quartzite.

The Rabbit Lake formation consists of laminated argillite and slate, bedded tuff, and hundreds of feet of saprolitized chloritized basalt. One 10-foot layer of thinly laminated lean ferruginous chert is interbedded in the laminated argillite.

\section{SECTION SIX MINE}

The Section Six mine (pl. 2, sec. 6, T. 46 N., R. 29 W.) was stripped by the Hanna Coal and Ore Corp. during $1950-51$, and 622,486 tons of ore was shipped during 1951-55. The mine is now idle.

Like the Maroco mine, the Section Six mine produced ore from only the thick-bedded facies of the Trommald formation and is on a southwest-plunging drag fold on the northwest flank of the same major syncline. The Mahnomen formation, consisting of quartzite and brown sericitic slate, is well exposed in the northwest bank of the mine. Near the southwest end of the mine a bed of soft-gray ashy material several feet thick was observed at the top of the Mahnomen formation. The soft rock is titaniferous and is perhaps decomposed tuff. Similar rock was penetrated by drill holes southwest of the mine. The thick-bedded iron-formation is very cherty, generally wavy bedded, and is 120 feet thick. Cherty beds near the top of the formation at the southwest end of the mine contain abundant granules and some oolites. Rocks of the Rabbit Lake formation consist of a 2- to 5 -foot layer of laminated gray and black argillite followed by at least 40 feet of gray-green and lightbrown saprolitized chloritized basalt believed to have been a flow. Manganiferous iron ore and iron ore were produced, and the ores were treated in the Maroco plant.

\section{VIRGINIA MINE}

The Virginia open-pit mine (pl. 3, secs. 4 and 5, T. 46 N., R. 29 W.) was stripped by Zontelli Bros., Inc., and first shipments were made in 1948. The total ore shipped through 1954 was 854,830 tons. The mine is now idle.

The Virginia mine is the only one in the North range that is in a lens of upper iron-formation within the Rabbit Lake formation, and the geology is strikingly different from any other place in the district. The ore body is situated on a group of southwestplunging drag folds on the northwest limb of a major syncline. Beds stratigraphically under the lens of iron-formation are exposed along the northwest bank of the mine. The underlying beds are gray laminated sericitic slate near the middle of the mine and black slate at the southwest end. The iron-formation is very cherty, very argillaceous, and is transitional into the underlying slate. Perhaps the iron-formation is so argillaceous that it behaved in a very incompetent manner when folded and yielded the most 
complex series of tight drag folds seen in the district (fig. 9). The limbs of the drag folds are nearly straight, and the crests and troughs very sharp and $\mathrm{V}$-shaped. The drag folds plunge $30^{\circ}-55^{\circ} \mathrm{SW}$., and some in the inaccessible southwest end appeared to plunge almost vertically. The ore is red and brown iron oxide interbedded with chert and argillite; no unoxidized iron-formation was observed. Manganiferous iron ore and iron ore were produced. The ore was treated in a concentrating plant at the mine.

\section{MALLEN MINE}

The Mallen open pit (pl. 4, sec. 17) was operated by the Hanna Coal and Ore Corp. who stripped the mine during 1951-52 and shipped 81,198 tons of ore in 1952 and 1953. It is now idle.

The Mahnomen formation on the south side of the mine is composed of gray and red-brown slate and siltstone. No quartzite was found.

The mine has excellent exposures of the thin-bedded facies of the Trommald formation; it strikes about N. $65^{\circ}$ E., is overturned, and dips $65^{\circ}-80^{\circ} \mathrm{SE}$. Local normal dips are in the southeast corner of the mine where a drag fold plunges to the northeast. The Trommald formation is almost entirely of the thinbedded facies. A layer of the thick-bedded facies about 10 feet thick was mapped at the top of the formation in the northwest corner of the mine; this pinched out northeastward within 300 feet, the distance to the exposures on the other side of the mine where the top of the iron-formation was cherty but thinly bedded.

In the northwest bank of the mine, three distinct stratigraphic layers were recognized in the lower part of the Rabbit Lake formation. The first above the contact was a 5- to 10-foot layer of light- and darkgray and red-brown laminated argillite and slate. The second was a 45-foot layer of gray and red-brown unbedded schist believed to be metamorphosed tuff or flow rock. The third unit, of unknown thickness, was largely dark-gray to black slate and lesser amounts of light-gray and brown slate and phyllite.

The ores of the Mallen mine were all hematitic and somewhat manganiferous. All iron-formation exposed in the mine was oxidized.

\section{CARLSON-NELSON MTNE}

The Carlson-Nelson mine (pl. 4, sec. 17) is in an eastern extension of the Rowe ore body, which is described below. This mine was stripped in 1955 and 1956 by Rhude and Fryberger. The exposed ironformation was examined in 1956 , but the mine was not mapped in detail.
The Trommald formation in the Carlson-Nelson mine strikes $\mathrm{N} .65^{\circ}$ E. and dips nearly vertical with the top on the northwest side. The Trommald formation includes the two (thin- and thick-bedded) facies common to it; the facies transition is roughly 10 to 20 feet thick and runs down the center of the mine. Other formations were not exposed in the mine in 1956 , but they are known from drilling near the Rowe mine and in the SE1/4 NW1/4 sec. 17. The Mahnomen formation is largely argillite and slate, and includes quartzite lenses that decrease in size and abundance eastward.

\section{ROWE MINE}

The Rowe mine (pl. 4, sec. 18) was one of the first open pits in the district; stripping began in 1912, and ore was shipped from 1914 to 1920 . It was operated by the Pittsburgh Steel Ore Co. for direct-shipping ore and wash ore that was treated in a plant on the property. The flooded mine is now held by the Hanna Iron Ore Co., which made small shipments during 1951-53 from reprocessed tailings. Total shipments through 1953 were 907,609 tons.

The Rowe ore body is at the end of a large northeast-plunging syncline in the thick-bedded facies of the Trommald formation. The iron-formation is probably partly wavy bedded, and perhaps a thin wedge of thin-bedded iron-formation occurs in the eastern part of the mine. The iron-formation in the western part is much drag folded, the axes plunging $35^{\circ}-58^{\circ}$ NE. An unpublished detailed planetable sheet of the geology is in the files of the U.S. Geological Survey, and a geologic map of the mine was published by Harder and Johnston (1918, pl. 20). Little or none of the Mahnomen formation was exposed in the pit; red and gray slate near the base of the Rabbit Lake formation was exposed in two areas in the north side of the mine. Harder and Johnston stated that the depth of the ore body was not known. Vertical holes were drilled north of the mine near the center of the syncline, and the deepest hole intersected the ironformation from 324 to 699 feet below the surface.

The Rowe ores were hematitic and generally low in manganese. Small pockets of manganiferous ore were found near the bottom of the Trommald formation; they were too small to mine separately (Harder and Johnston, 1918, p. 141).

\section{SNOWSHOE MINE}

The Snowshoe mine (pl. 4, secs. 17 and 18) is an open pit operated during $1944-48$ by Rhude, Fryberger, \& Leach, and during 1952-54 by the Hanna Coal and Ore Corp. Total shipments have been 
463,632 tons of argillaceous high-phosphorus hematitic ore. The mine is considered exhausted (Wade and Alm, 1955, p. 186).

The Snowshoe mine was described by Grout and Wolff (1955, p. 71) as being in a northeast-plunging syncline. The syncline observed is, however, a minor structure at the west end of the mine and only a drag fold on a southeast-dipping monocline. The general structure is more clearly shown at the east end of the mine where there are no drag folds.

The geology of the Snowshoe ore body is unique in the Cuyuna district, and the relation to the rest of the district is not known. The ores occurred in a lenticular mass of iron-bearing rock that dips gently southeastward, seemingly conformable between a gray and greenish-gray micaceous siltstone and argillite footwall and a finely laminated greenish-gray argillite and siltstone hanging wall. Analyses of the wallrocks (samples 1042, 1043) and of a grab sample of ore (sample 1044) are shown in table 6. The phosphorus content of the ore in particular, but also of the wallrocks, is notably high. The iron content of the hanging wall is higher than the footwall, but it does not approach that of an iron-formation. Part of the ore was finely laminated. No cherty layers were found in the ore, and no unoxidized iron-formation occurs in the deposit. The lenticular mass of iron-bearing rock was thickest, nearly 100 feet, near the center of the mine and thinned downdip and in both directions along the strike. The lower contact of the iron-bearing rock was sharp; most of the underlying beds are gray siltstone. The upper contact was transitional, the ore grading upward into soft red ferruginous clay, then red argillite or slate, finally into hard gray-green laminated argillite-all in a distance of 20 to 30 feet. The ores probably passed into similar argillite downdip. Such limitation of the ore-bearing formation to a small lenticle is unknown in the Trommald formation at any place in the district, and the ore is unlike any formed in the Trommald formation; therefore, this lenticle is probably not that formation. Minor shears occurred near the lower contact, but there was no evidence of major faulting; the upper contact, being transitional, was obviously not faulted.

The rocks below and above the ore in the Snowshoe mine resemble rocks known elsewhere in the Mahnomen formation, and the stratigraphic position of the iron-bearing lens appears to be perhaps as much as 1,000 feet below the top of that unit. No reason is known for such a concentration of ore in the Mahnomen formation.
SAGAMORE MTNE AND THE SYRACUSE PROPERTY

The Sagamore mine (pl. 4, sec. 19, T. 46 N., R. 29 W.) has been one of the most important in the Cuyuna district. The property was explored from 1911 until 1919 when stripping was started by John A. Savage \& Co. Operations are in two large connected open pits. The Sagamore mine together with the Syracuse mine (lot 4, sec. 19) and the Syracuse reserve (SE1/4.SE1/4 sec. 24 , T. 46 N., R. 30 W.) produced $10,588,005$ tons of ore through 1955 . The ore is dried in rotary kilns in a large plant at the mine. The mine and drying plant have been operated by the Sagamore Ore Mining Co. (Pickands Mather \& Co., Agents) since 1928.

The Sagamore ore bodies occur in a large southwest-plunging drag-folded syncline, which may itself be an isolated drag fold on a larger synclinal structure. The plunging syncline is cut off sharply at the southwest end along a line trending due west; this line cuts across the trend of the fold axes and probably is a fault. Beds near the top of the Trommald formation and near the base of the Rabbit Lake formation north of the fault are brought into close proximity with argillite and siltstone believed to be the Mahnomen formation south of the fault. Exposures near the contact are scant and poor, and drilling data are not conclusive. The limits of the Trommald formation and satisfactory interpretation of the geologic structure along the southeast side of the mine for about 1,000 feet northeast of the fault have not been determined, and it is possible that the iron-formation extends considerably beyond the explored area at this place.

The Mahnomen formation is exposed at several places along the northwest side of the No. 2 mine and along the east side of the No. 1 mine. The Trommald formation is practically all thin bedded. The nearness of the transition or actual extension of the transition into the southwest end of the mine is suggested by one 6 - to 10 -inch bed of mottled chert near the top of the Trommald formation in the $\mathrm{NE}_{1} / 4 \mathrm{SW}^{1} / 4$ sec. 19 in the No. 2 pit. Only at this mine is argillaceous material intercalated with the iron-formation in a persistent layer over a considerable area. The intermediate argillite layer or "paint rock" was recognized by Royce in preparing mine cross sections used by Pickands Mather \& Co. many years ago. It is 5 to 30 feet thick, perhaps averages 20 feet thick, and has been traced in most of the mine except the southwest end, where it may pinch out. The layer is ferruginous and grades into the enclosing iron-formation. No correlative layer has been found in other parts of the district. 
The No. 2 mine and the southwest end of the No. 1 mine are separated by a long narrow mass of unmined rock-oxidized iron-formation along the southeast side and gray chlorite schist on the northwest side. The schist has been variously interpreted in the past and recently described by Schmidt and Dutton (1952) and Grout and Wolff $(1955, \mathrm{pl} .2$, and p. 70, 73) as a metamorphosed intrusive rock in the iron-formation. Despite the lack of bedding the schist is probably a metamorphosed sedimentary rock and is at the base of the Rabbit Lake formation, similar to rock at the base of the same formation along the south side of the Huntington-Armour No. 1 group of mines. At the southwest end of the mass, near the proposed fault, black argillite of the Rabbit Lake formation was penetrated by one drill hole.

Ore was red brown in the southwest end of the No. 1 pit adjacent to the rock ridge separating the open pits; most of the ore was yellow brown and brown in the rest of the mine. Large amounts of unoxidized carbonate-rich and silicate-rich iron-formation are well exposed in many places, and the relationships between ore and parent rock may be readily studied (figs. 18, 21). The brown ore cuts across the bedding in many exposures, and the contacts of the ore cut abruptly across anticlines and synclines.
Much of the Sagamore mine ore is manganiferous, and distribution of the manganese is controlled stratigraphically. It occurs near the center of the Trommald formation above and below the argillaceous layer, the most manganiferous ore being above.

\section{SELECTED REFERENCES}

Adams, F. S., 1910, The iron formation of the Cuyuna range, Minnesota : Econ. Geology, v. 5, p. 729-740.

1911a, The iron formation of the Cuyuna range; the Deerwood iron formation: Econ. Geology, v. 6, p. 60-70. 1911b, The iron formation of the Cuyuna range; the ores: Econ. Geology, v. 6, p. 156-180.

Aldrich, H. R., 1929, The geology of the Gogebic iron range of Wisconsin: Wisconsin Geol. Nat. History Survey Bull. 71, $279 \mathrm{p}$.

Alexandrov, E. A., 1955, Contribution to studies of origin of Pre-Cambrian banded iron ores: Econ. Geology, v. 50, no. 5 , p. $459-468$.

American Iron Ore Association, 1957, Average analyses Lake Superior iron ores, season 1956: Cleveland, Ohio, $66 \mathrm{p}$.

Appleby, W. R., and Newton, Edmund, 1915, Geology, in Preliminary concentration tests on Cuyuna ores: Minnesota School Mines Expt. Sta. Bull. 3, p. 8-12.

Bath, G. D., 1951, Magnetic base stations in Lake Superior iron districts: U.S. Bur. Mines Rept. Inv. 4804, 16 p.

Black, Maurice, 1933, The precipitation of calcium carbonate on the Great Bahama Bank; Geol. Mag., no. 832 (v. 70, no. 10), p. 455-466, 1 fig., 1 pl.

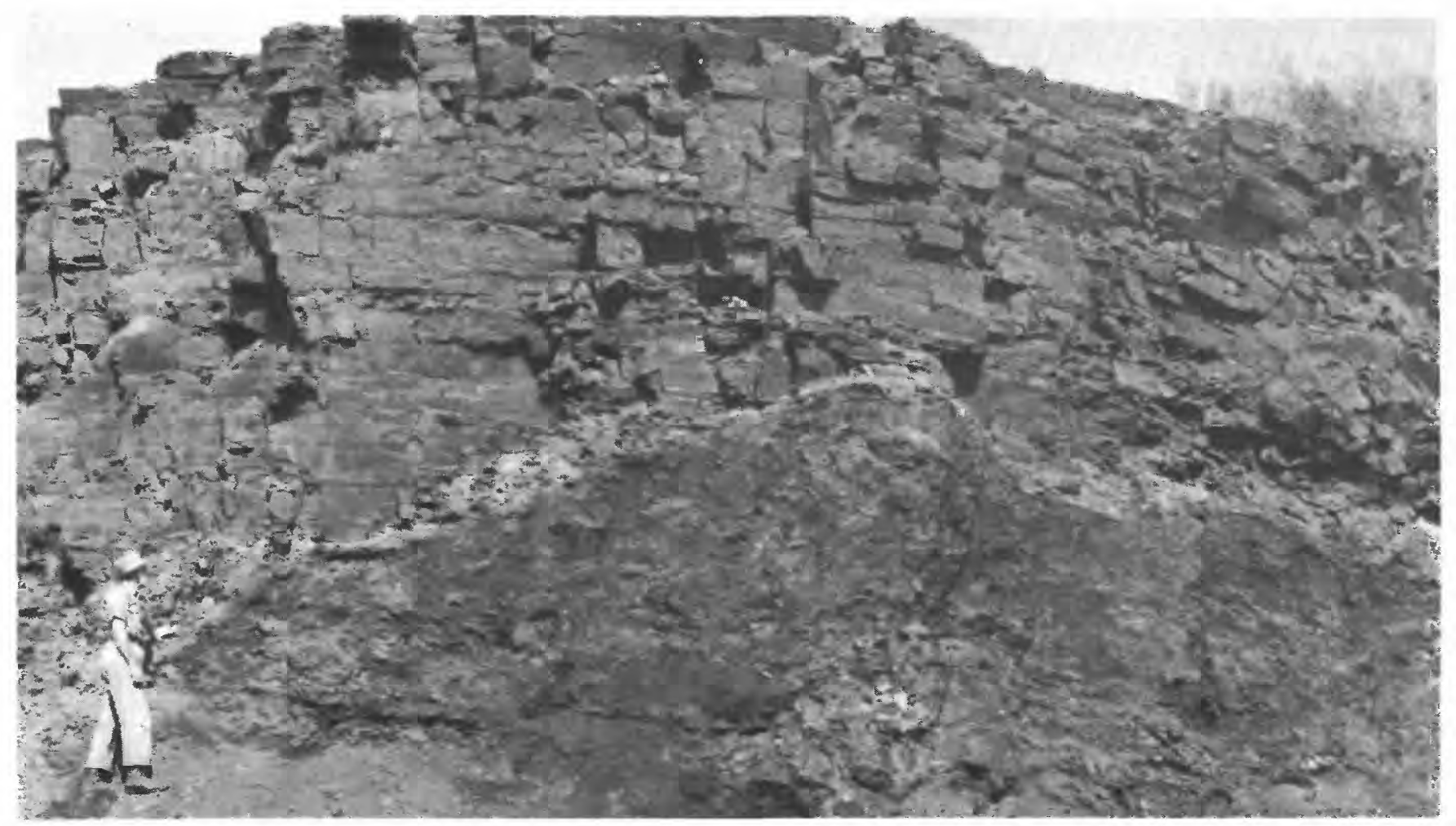

Frgore 21.-Brown gnarled ore occurring beneath unoxidized thin-bedded Trommald formation, Sagamore No. 2 mine. The bed ding is nearly horizontal as the exposure is near the crest of a gentle anticline. The ore-iron-formation contact cuts across the bedding at a low angle on the left side of the picture. Light zone above contact is soft, partly altered, nontronitic fron-formation. 
Blake, R. L., 1958, A study of the iron silicate minerals with special emphasis on the iron-formation in the Cuyuna district, Minnesota [abs.], in Inst. on Lake Superior Geology, Duluth, 1958 [Proc.]: Minneapolis, Univ. Minnesota, Center for Continuation Study, p. 17.

Butler, B. S., and Gale, H. S., 1912, Alunite, a newly discovered deposit near Marysvale, Utah: U.S. Geol. Survey Bull. 511, 64 p.

Castano, J. R., and Garrels, R. M., 1950, Experiments on the deposition of iron with special reference to the Clinton iron ore deposits: Econ. Geology, v. 45, no. 8, p. 755-770.

Cheney, C. A., Jr., 1915, Structure of the Cuyuna iron-ore district of Minnesota: Eng. Mining Jour., v. 99, p. 11131115.

Clements, J. M., 1903, The Vermilion iron-bearing district of Minnesota: U.S. Geol. Survey Mon. 45, 463 p.

Clements, J. M., and Smyth, H. L., 1899, The Crystal Falls iron-bearing district of Michigan, with a chapter on the Sturgeon River tongue, by W. S. Bayley, and an introduction by C. R. Van Hise: U.S. Geol. Survey Mon. 36, 512 p.

Collins, W. H., Quirke, T. T., and Thomson, Ellis, 1926, Michipicoten iron ranges: Canada Geol. Survey Mem. 147, $175 \mathrm{p}$.

Cook, S. R. B., 1936, Microscopic structure and concentrability of the important iron ores of the United States: U.S. Bur. Mines Bull. 391, 121 p.

Credner, H., 1869, Die vorsilurischen Gebilde der "Oberen Halbinsel von Michigan" in Nord-Amerika: Deutsche geol. Gesell. Zeitschr. 21, p. 516-554.

Crowell and Murray, Inc., 1930, Geology, Cuyuna range, in The iron ores of Lake Superior: Cleveland, Ohio, Penton Press Co., p. 18-21.

Dougherty, E. Y., and Fitzhugh, E. F., 1946, Magnetic reconnaissance in north-central Minnesota in 1945: U.S. Bur. Mines Rept. Inv. 3919, 7 p., 10 pls., incl. index map.

Dunn, J. A., 1935, The origin of iron ores in Singhbhum, India : Econ. Geology, v. 30, no. 6, p. 643-654.

- 1937, The mineral deposits of eastern Singhbhum and surrounding areas: Geol. Survey India Mem. 69, pt. 1, 279 p.

Emmons, W. H., and Grout, F. F., eds., 1943, Mineral resources of Minnesota: Minnesota Geol. Survey Bull. 30, p. 23-26.

Foster, J. W., and Whitney, J. D., 1851, Report on the geology of the Lake Superior land district; Part 2, The iron region, together with the general geology: U.S. 32d Cong., spec. sess., S. Ex. Doc. 4, 406 p.

Goodwin, A. M., 1956, Facies relations in the Gunflint iron formation: Econ. Geology, v. 51, no. 6, p. 565-595.

Gordon, Mackenzie, Jr., Tracey, J. I., Jr., and Ellis, M. W., 1958, Geology of the Arkansas bauxite region: U.S. Geol. Survey Prof. Paper 299, 268 p.

Grosh, W. A., Pennington, J. W., and Wasson, P. A., 1953, Investigation of Scallon-Todd Lease, Aitkin County, Minnesota: U.S. Bur. Mines Rept. Inv. 4979, 24 p.

Grout, F. F., 1941, Emergency reserves of manganese on the Cuyuna Range, Minnesota: Econ. Geology, v. 36, no. 8, p. 848 .

- 1942, Manganese for emergency use on the Cuyuna range: Eng. Mining Jour. 143, no. 7, p. 43-44.

- 1946a, Acmite occurrences on the Cuyuna range, Minnesota : Am. Mineralogist, v. 31, p. 125-130.

1946b, Microscopic characters of vein carbonates: Econ. Geology, v. 41, no. 5, p. 475-502.
CUYUNA NORTH RANGE, MINNESOTA

Grout, F. F., Gruner, J. W., Schwartz, G. M., and Thiel, G. A., 1951, Precambrian stratigraphy of Minnesota: Geol. Soc. America Bull. v. 62, p. 1017-1078.

Grout, F. F., and Wolff, J. F., Sr., 1955, The geology of the Cuyuna district, Minnesota: Minnesota Geol. Survey Bull. $36,144 \mathrm{p}$.

Grout, F. F., and others, 1932, Geologic map of the State of Minnesota [2 sheets]. Scale 1:500,000: Minnesota Geol. Survey.

Gruner, J. W., 1922, Organic matter and the origin of the Biwabik iron-bearing formation of the Mesabi range: Econ. Geology, v. 17, no. 6, p. 407-460.

1926, The Soudan formation and a new suggestion as to the origin of the Vermilion iron ores: Econ. Geology, v. 21, p. $629-644$.

1932, Additional notes on secondary concentration of Lake Superior iron ores: Econ. Geology, v. 27, no. 2, p. 189-205; discussion by Stephen Royce, no. 5, p. 487-491, v. 28, no. 3 , p. 293,1933 .

1937, Hydrothermal leaching of iron ores of the Lake Superior type, a modified theory: Econ. Geology, v. 32, no. 2, p. 121-130; discussions by Stephen Royce, no. 3, p. 389 ; C. O. Swanson, no. 6, p. $855-857$; and J. A. Dunn, no. 7 , p. 976-977.

1946, The mineralogy and geology of the taconites and iron ores of the Mesabi range, Minnesota: St. Paul, Minn., Iron Range Resources and Rehabilitation Comm. and Minnesota Geol. Survey, $127 \mathrm{p}$.

- 1947, Groutite, $\mathrm{HMnO}_{2}$, a new mineral of the diasporegoethite group [Cuyuna iron range, Minnesota]: Am. Mineralogist, v. 32, nos. 11-12, p. 654-659, 3 figs.

1956, The Mesabi range: Geol. Soc. America Guidebook, the Precambrian of northeastern Minnesota, p. 182215.

Guild, P. W., 1953, Iron deposits of the Congonhas district, Minas Gerais, Brazil : Econ. Geology, v. 48, p. 639-676. 1957, Geology and mineral resources of the Congonhas district, Minas Gerais, Brazil: U.S. Geol. Survey Prof. Paper 290, 90 p.

Han, T. M., 1958, The mineralogy, paragenesis, and origin of the Cuyuna sulfide deposits [abs.], in Institute on Lake Superior Geology, Duluth, 1958 [Proc.]: Minneapolis, Univ. Minnesota, Center for Continuation Study, p. 24.

Harder, E. C., 1910, Cuyuna iron range, Minnesota, in Manganese deposits of the United States: U.S. Geol. Survey Bull. 427, p. 130-131.

1917a, Manganiferous iron ores: U.S. Geol. Survey Bull. 666, p. 197-209.

1917b, Manganiferous iron ores of the Cuyuna district, Minnesota: Am. Inst. Mining Engineers Bull. 129, p. 1313-1344.

1918, Manganiferous iron ores of the Cuyuna district, Minnesota: Am. Inst. Mining Fngineers Trans. 58, p. 453486.

Harder, E. C., and Johnston, A. W., 1917, Notes on the geology and iron ores of the Cuyuna district, Minnesota: U.S. Geol. Survey Bull. 660-A, 26 p.

1918, Preliminary report on the geology of East Central Minnesota including the Cuyuna iron-ore district: Minnesota Geol. Survey Bull. 15, 178 p.

Hay, O. P., 1923, Description of remains of Bison occidentalis from Central Minnesota: U.S. Natl. Mus. Proc., v. 63, art. $5,8 \mathrm{p}$. 
Henderson, J. R., Hill, M. E., and Meuschke, J. L., 1949a, Total intensity aeromagnetic map and accompanying magnetic profiles of the northern part of Crow Wing County and part of Cass County, Minnesota: U.S. Geol. Survey Geophys. Inv. Map, 2 sheets.

1949b, Total intensity aeromagnetic map and accompanying magnetic profiles of the southern part of Crow Wing County, Minnesota: U.S. Geol. Survey Geophys. Inv. Map, 2 sheets.

Henderson, J. R., and Meuschke, J. L., 1953a, Total intensity aeromagnetic and geologic map of parts of Kanabec, Mille Lacs, and Pine Counties, Minnesota: U.S. Geol. Survey Geophys. Inv. Map GP-102.

- 1953b, Total intensity aeromagnetic and geologic map of southern Aitkin County and northern Mille Lacs County, Minnesota: U.S. Geol. Survey Geophys. Inv. Map GP-101.

- 1953c, Total intensity aeromagnetic and geologic map of northern Aitkin County, Minnesota: U.S. Geol. Survey Geophys. Inv. Map GP-100.

Himrod, Anna, 1940, The Cuyuna range, a history of a Minnesota iron mining district: St. Paul, Minn., Minnesota Hist. Recs. Survey Proj., WPA, 168 p.

Holbrook, S. H., 1939, Iron Brew : New York, Macmillan Co., 352 p.

Irving, R. D., 1886, Origin of the ferruginous schists and iron ores of the Lake Superior Region: Am. Jour. Sci., 3 ser., v. 32, p. 255-272.

Irving, R. D., and Van Hise, C. R., 1892, The Penokee ironbearing series of Michigan and Wisconsin: U.S. Geol. Survey Mon. 19, 534 p., 37 pls.

Iverson, C. L., 1958, The properties of silica gel and its possible relationship to the development of Lake Superior type iron ores [abs.], in Institute on Lake Superior Geology, Duluth, 1958 [Proc.]: Minneapolis, Univ. Minnesota, Center for Continuation Study, p. 22.

James, H. L., 1951, Iron formation and associated rocks in the Iron River district, Michigan: Geol. Soc. America Bull., จ. 62 , p. 251-266.

- 1953, Origin of the soft iron ores of Michigan (discussion) : Econ. Geology, v. 48, p. 726-728.

1954, Sedimentary facies of iron formation: Econ. Geology, v. 49, no. 3, p. 235-293.

- 1955, Zones of regional metamorphism in the Precambrian of northern Michigan: Geol. Soc. America Bull., v. 66 , no. 12 , p. 1455-1488.

Joseph, T. L., and Kinney, S. P., 1927, Minnesota manganiferous iron ore in relation to the iron and steel industry: Minnesota School Mines Expt. Sta. Bull. 12, 101 p.

Krauskopf, K. B., 1956, Dissolution and precipitation of silica at low temperatures: Geochim. et Cosmochim. Acta, v. 10, p. 1-26.

Krumbein, W. C., and Garrels, R. M., 1952, Origin and classification of chemical sediments in terms of $\mathrm{pH}$ and oxidation-reduction potentials: Jour. Geology, v. 60, p. 1-33.

Lake Superior Iron Ore Association, 1938, Lake Superior iron ores: Cleveland, Ohio, $364 \mathrm{p}$.

Lane, A. C., 1924, Native silver in an iron mine [abs.] : Geol. Soc. America Bull., v. 35, no. 1, p. 127-128; Pan-Am. Geol., v. 41 , no. 2 , p. 160.
Leith, C. K., 1903, The Mesabi iron-bearing district of Minnesota: U.S. Geol. Survey Mon. 43, 316 p., 33 pls.

1906, A summary of Lake Superior Geology with special reference to recent studies of the iron-bearing series: Am. Inst. Mining Engineers Trans., v. 36, p. 101-153.

1907, The geology of the Cuyuna iron range, Minnesota : Econ. Geology, v. 2, p. 145-152.

Leith, C. K., Lund, R. J., and Leith, Andrew, 1935, PreCambrian rocks of the Lake Superior region, a review of newly discovered geologic features, with a revised geologic map: U.S. Geol. Survey Prof. Paper 184, 34 p.

Leverett, Frank, 1932, Quaternary geology of Minnesota and parts of adjacent States with contributions by Frederick W. Sardeson: U.S. Geol. Survey Prof. Paper 161, 149 p., 5 pls.

Lewis, W. E., 1951, Relationship of the Cuyuna manganiferous resources to others in the United States, in Mining Symposium-Geology of the Cuyuna range: Minneapolis, Univ. Minnesota, Center for Continuation Study, p. 30-43.

McCarty, E. P., 1915, Manganiferous iron ores of the Cuyuna Range [Minn.]: Eng. Mining Jour. 100, p. 400-402.

McCormack, C. P., 1925, Economics of the Cuyuna manganiferous iron ores: Am. Inst. Mining Metall. Engineers Trans., v. 71, p. 386-397.

Mann, V. I., 1953, The relation of oxidation to the origin of soft iron ores of Michigan: Econ. Geology, v. 48, p. 251281.

Moore, E. S., and Maynard, J. E., 1929, Solution, transportation, and precipitation of iron and silica: Econ. Geology, v. 24 , no. 3 , p. $272-303$; no. 4 , p. $365-402$; no. 5 , p. 506-527.

Newland, D. H., 1922, Paragenesis of the martite ore bodies and magnetics of the Mesabi Range: Econ. Geology, $\nabla$. 17 , no. 4, p. 299-302.

Newton, Edmund, 1915, Concentration of Cuyuna ores: Lake Superior Mining Inst. Proc. 20, p. 200-212.

1918, Manganiferous iron ores of the Cuyuna district, Minnesota: Minnesota School Mines Expt. Sta. Bull. 5, $126 \mathrm{p}$.

Percival, F. G., 1981, The iron ores of Noamundi, Singhbhum, India: Mining Geol. Metall. Inst. India Trans., v. 26, no. 3, p. 167-271.

Pfleider, E. D., 1957, The Cuyuna iron range; its competitive challenge: Skillings Mining Review, March 9, 1957.

Royce, Stephen, 1936, Geology of the Lake Superior iron deposits: Lake Superior Mining Inst. Proc. 29, p. 68-107.

1938, Geology of the iron ranges; the influence of geological conditions on mining practice, in Lake Superior Iron Orés: Cleveland, Ohio, Lake Superior Iron Ore Assoc., p. 27-61.

1942, Iron ranges of the Lake Superior district, in

Newhouse, W. H., ed., Ore deposits as related to structural features: Princeton, N. J., p. 54-63, 10 flgs.

Sakamoto, Takao, 1950, The origin of the pre-Cambrian banded iron ores: Am. Jour. Sci., v. 248, no. 7, p. 449-474.

Schmidt, R. G., 1958a, Geology of the southwestern part of the North range, Cuyuna district, Minnesota: U.S. Geol. Survey Mineral Inv. Field Studies Map MF-181.

1958b, Titaniferous sedimentary rocks in the Cuyuna district, central Minnesota: Econ. Geology, v. 53, p. 708721.

1959, Geology of the northern and eastern parts of the North range, Cuyuna district, Minnesota: U.S. Geol. Survey Mineral Inv. Field Studies Map MF-182. 
Schmidt, R. G., and Dutton, C. E., 1952, Progress report on geologic study of Crosby and Ironton area of the Cuyuna range, Crow Wing County, Minnesota: U.S. Geol. Survey open-file report, 3 p., 7 maps.

1957, Bedrock geology of the south-central part of the North range, Cuyuna district, Minnesota: U.S. Geol. Survey Mineral Inv. Field Studies Map MF-99.

Schwartz, G. M., 1942, Correlation and metamorphism of the Thomson formation, Minnesota: Geol. Soc. America Bull., v. 53, no. 7, p. 1001-1020.

- 1951a, Regional setting of the Cuyuna range, in Mining Symposium-Geology of the Cuyuna range: Minneapolis, Univ. Minnesota, Center for Continuation Study, p. 1-3.

- 1951b, Minnesota iron sulphide, in Mining SymposiumGeology of the Cuyuna range: Minneapolis, Univ. Minnesota, Center for Continuation Study, p. 44-45.

Schwartz, G. M., and Thiel, G. A., 1954, Minnesota's rocks and waters: Minnesota Geol. Survey Bull. 37, 366 p.

Shapiro, Leonard, and Brannock, W. W., 1953, A field method for the determination of titanium in rocks: Econ. Geology, จ. 48 , no. 4 , p. 282-287.

Shelton, S. W., and Fine, M. M., 1941, Ferrogradé manganese concentrates from the Cuyuna range: U.S. Bur. Mines Rept. Inv. 3582, $14 \mathrm{p}$.

Spencer, G. H., Jr., 1958, The role of interstitial and combined waters in the development of Lake Superior iron ores [abs.], in Institute on Lake Superior Goology, Duluth, 1958 [Proc.]: Minneapolis, Univ. Minnesota, Center for Continuation Study, p. 23.

Spurr, J. E., 1894, The stratigraphic position of the Thomson slates : Am. Jour. Sci., 3d ser., v. 48, p. 159-166.

Stauffer, C. R., 1945, Some Pleistocene mammalian inhabitants of Minnesota: Minnesota Acad. Sci. Proc., v. 13, p. 20-43.

Thiel, G. A., 1924a, High temperature manganese veins of the Cuyuna range: Econ. Geology, จ. 19, no. 4, p. 377-381.

$1942 \mathrm{~b}$, Relations of manganese and iron minerals in manganiferous iron ores, with special reference to the Cuyuna range, in The manganese minerals, their identification and paragenesis: Econ. Geology, v. 19, p. 107-145. 1924c, Commercial possibilities of the magnetite slates of the Cuyuna range: Eng. Mining Jour., v. 118, no. 19, p. 735-738.

1926, Phosphorus iron-ores on the Cuyuna range: Eng. Mining Jour., v. 121, p. 687-690.

1927, Geology of the Cuyuna range: Geol. Soc. America Bull., v. 38, p. 783-793.

Twenhofel, W. H., 1932, Treatise on sedimentation: Baltimore, Md., Williams \& Wilkins Co., 926 p.

Tyler, S. A., 1949, Development of Lake Superior soft iron ores from metamorphosed iron formation: Geol. Soc. America Bull., v. 60, p. 1101-1124.

Tyler, S. A., and Twenhofel, W. H., 1952, Sedimentation and stratigraphy of the Huronian of Upper Michigan, Part 1: Am. Jour. Sci., v. 250, p. 1-27.

U.S. Bureau of Mines, 1952, United States deposits, Cuyuna range, Minnesota, chap. 7 of Materials survey, manganese, compiled for the National Security Resources Board by the U.S. Dept. of the Interior, Bureau of Mines, with the cooperation of the U.S. Geol. Survey, p. 14-21.

1954, Minerals Yearbook, v. 3.

University of Minnesota, 1920-58, Bulletin, Mining Directory Issue, published annually.
Upham, Warren, 1888, The geology of Crow Wing and Morrison Counties, in The geology of Minnesota, final report of the Geological and Natural History Survey of Minnesota, v. 2, by N. H. Winchell assisted by Warren Upham, p. 580-611.

Van Evera, J. W., 1923, Brief history of the Cuyuna range: Lake Superior Mining Inst. Proc., v. 23, p. 85-90.

Van Hise, C. R., 1889, The iron ores of the Penokee-Gogebic series of Michigan and Wisconsin: Am. Jour. Sci. 3d ser., v. 37, p. 32-48.

1892, The iron ores of the Lake Superior region: Wisconsin Acad. Sci. Trans. 8, p. 219-227.

1896, Principles of North American pre-Cambrian geology: U.S. Geol. Survey 16th Ann. Rept., Pt. 1, p. 571-874. 1901, The iron-ore deposits of the Lake Superior region: U.S. Geol. Survey 21st Ann. Rept., Pt. 3, p. 305-434.

Van Hise, C. R., and Bayley, W. S., 1897, The Marquette ironbearing district of Michigan: U.S. Geol. Survey Mon. 28, $608 \mathrm{p}$. , atlas.

- 1900, Description of the Menominee quadrangle [Mich.] : U.S. Geol. Survey Atlas, Folio 62, 13 p., maps.

Van Hise, C. R., and Leith, C. K., 1911, The geology of the Lake Superior region: U.S. Geol. Survey Mon. 52, 641 p., 49 pls.

Van Hise, C. R., Leith, C. K., and Zapffe, Carl, 1911, The iron ores of the Cuyuna district, in The geology of the Lake Superior Region: U.S. Geol. Survey Mon. 52, p. 216-224.

Wade, H. H., and Alm, M. R., 1954, Mining directory of Minnesota: Univ. Minnesota School Mines Expt. Sta. Bull., v. 57, no. 9, $274 \mathrm{p}$.

1955, Mining directory of Minnesota: Univ. Minnesota School Mines Expt. Sta. Bull., v. 58, no. 9, 278 p.

Wagner, P. A., 1928, The iron deposits of the Union of South Africa: Geol. Survey South Africa Mem. 26, 268 p.

Washington, H. S., 1923, Petrology of the Hawaiian Islands; III, Kilauea and General petrology of Hawaii : Am. Jour. Sci., 5th ser., v. 6, p. 338-367.

Weidman, Samuel, 1904, The Baraboo iron-bearing district of Wisconsin: Wisconsin Geol. Nat. History Survey Bull. 13, $190 \mathrm{p}$.

Wentworth, C. K., 1938, Ash formations of the Island Hawail : Hawaiian Volcano Observatory, 3d Spec. Rept., 183 p.

White, D. A., 1954, The stratigraphy and structure of the Mesabi Range, Minnesota: Minnesota Geol. Survey Bull. $38,92 \mathrm{p}$.

Whittlesey, Charles, 1852, Geological report on that portion of Wisconsin bordering on the south shore of Lake Superior, in Owen, D. D., Report of a geological survey of Wisconsin, Iowa, and Minnesota: Philadelphia, Pa., p. 421473.

Winchell, N. H., 1900, Mineralogy and petrology of Minnesota : Minnesota Geol. Survey Final Rept., v. 5, p. 937-1006. 1907, The Cuyuna iron range: Econ. Geology, v. 2, p. $565-571$.

Wolff, J. F., Sr., 1919, Correlation of the Mesabi and Cuyuna ranges: Skillings Mining Review, 7, no. 45, p. 1 and 4. 1951, The geologic stratigraphy and correlation of the Cuyuna iron district of Minnesota, in Mining Symposium - Geology of the Cuyuna range : Minneapolis, Univ. Minnesota, Center for Continuation Study, p. 4-29.

Woolnough, W. G., 1941, Origin of banded iron deposits; a suggestion: Econ. Geology, v. 36, no. 5, p. 465-489. 
Woyski, M. S., 1949, Intrusives of Central Minnesota: Geol. Soc. America Bull., v. 60, p. 999-1016.

Zapffe, Carl, 1911, Geology of the Cuyuna iron ore district, Minnesota : Mining World, v. 34, p. 585-588.

1925a, Manganiferous iron ores of Cuyuna district, Minnesota: Am. Inst. Mining Engineers Trans. 71, p. 372-385.

- 1925b, Stratigraphy and correlation of the Cuyuna iron ore district, Minnesota: Lake Superior Mining Inst. Proc., v. 24, p. $89-105$.

1926, Further data on the correlation of the Cuyuna iron-bearing member : Lake Superior Mining Inst. Proc., v. 25, p. 219-227.
Zapffe, Carl, 1928, Geologic structure of the Cuyuna iron district, Minnesota: Econ. Geology, v. 23, no. 6, p. 612-646.

1930, Cuyuna stratigraphy: Lake Superior Mining Inst. Proc., v. 28, p. 99-106.

1933, The Cuyuna iron-ore district, in Hotchkiss, W. O., Internat. Geol. Cong., 16th sess., United States, Guidebook, Excursion C-4, p. 72-88.

1938, Discovery and early development of the iron ranges, in Lake Superior Iron Ores: Cleveland, Ohio, Lake Superior Iron Ore Assoc., p. 13-26.

Zapffe, Carl, and Barrows, W. A., Jr., 1912, The iron ores of the South Range of the Cuyuna District, Minn.: Am. Inst. Mining Engineers Trans. 44, p. 3-13. 


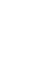

,$$
\text { . }
$$ 


\section{INDEX}

A

Page

Acknowledgments
Adams, Cuyler.

Adams, F. S., cited.

Adams, Mrs. Cuyler.

Adbar Development Co.

Aitkin

Aitkin County......................... 3, 6, 10,11, 38, 65

Alexandro, E. A., quoted.........................

Algoman granite..................................... 11

Algoman MeGrath gneiss.............. 10

Altitudes.

Alumina content, sedimentary and volcanic rocks - 33-34

Trommald formation.........................

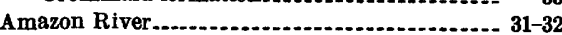

Amherst Mining Co.............................. 67

Anslyses, chemical, Mahnomen formation...... 14

chemical, miscellaneous rocks.................. 26

Rabbit Lake formation. ....................

Trommald formation, thick-bedded

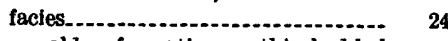

Trommald formation, thin-bedded facies................................ 20, 21, 28

grades of ore................................ $\quad 60$

semiquantitative spectrographic, minor constituents.

Animikie group, Emily district

Mesabi district........................... 7, 11, 12, 39

Anomalies, magnetic............. 5, 10, 14, 15, 57,64, 83

Anticlines....................................... 8, 45, 46

Alstead-North Hillcrest mine.................. 82

Armour No. 1 mine........................... 73

Feigh mine..................... 63, 75, 76; pls. 3, 7, 8

Huntington mine............................ 63,77

Louise mine.................................. 80

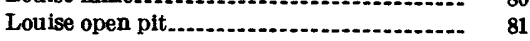

Mahnomen No. 1 mine................. 15, 78; pl. 3

Mangan No. 1 pit_.......................... 83

Merritt mine....................................... 69

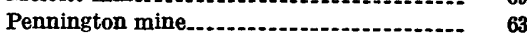

Sagamore No. 1 open pit.................... 87

South Hillerest mine......................... 63, 76

Sultana-Hopkins mine

Argillite ...................... 36, 38, 86

Mahnomen formation.... 11, 14, 15, 16-17, 82, 85, 86 (paint rock) in thin-bedded facies of Trommald formation, Sagamore mine.... 20 ,

25, 54; pl. 4

Pokegama formation. ....................... 38 Trommald formation_...... 25, 33, 47, 54, 67, 72,73 Arko Mining Co .

Ayres, H. B

B

Baraboo district, Wisconsin.

Baraboo quartzite of Wisconsin

Barrows, W. A., Jr. quoted

$26,40,41,42,43,48,84$

Bastron, Harry, analyst........................ 61

Biwabik formation........................... 8, 14,33, 37

Biwablk iron-formation, Emily district......... 18

Mesabi district. ............................. 32, 39

Blackhoof Lake.................................. 16, 63

Boron content, of iron-formation in the Trom-

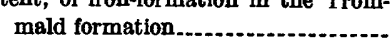

of ore.

(1) 57
Page

Brainerd.................................. 3, 5, 10,40,41

Browerville........................................... 10

Butler Bros...................... 68, 69

$\mathbf{C}$

Carlton County

Cass County.............. $\quad 7,10$

Chippewa quartzite of Wisconsin

Coates and Tweed.

Credner, H., cited................................ 56

Cretaceous, fossils................................. 11

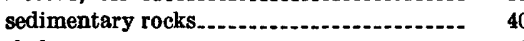

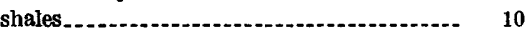

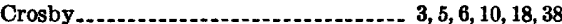

Crosby Exploration Co., log of drill hole........ 37

Crow Wing County ......... 3,10

Cuyruna................................ 5, 6, 38

Cuyuna Ore Co....................... 77, 78, 79,80,81

Cuyuna-Duluth Iron Co........................ 74

Cuyuna Mille Lacs Iron Co...

Cuyuna-Minneapolis Iron-Co

Cuyuna Range Railroad.

\section{D}

Dam Lake.

$5,7,10,13$

Deerwood.

Denham...-

10

41-42

Dikes, diabase

diorite.

gabbro.

Donahue, E. J. W-

Drainge. .......

Edson, W. D.................. Elephas sp., near Brainerd................... 41

Emily district.................. 3,4,8, 9, 10,11, 35, 39, 40 Biwabik iron-formation..................... 18

Esquagamah Lake................................. 10

Evergreen Mines Co........................... 77

Exploration for ore, recommendations........... 62-64

\section{F}

Faults...... 8, 35, 36, 38, 39, 45, 46-47, 67, 75, 77, 84, 86, 87

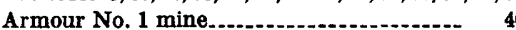

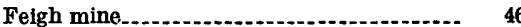
Milford mine................................. 67 Pennington mine................................ 46 Sagamore-Menomin Lake............... 36, 38 Sagamore mine........................ 46 South Hillerest mine......................... 46

Fieldwork

Fogelstrom, P. G..............

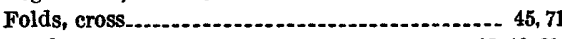
drag . . . $63,64,67,68,69,75,78,79,81,83,84,85,86$ iron-formation................................. 60 Mahnomen formation. Northland mine............................... 67 occurrence of ore bodies..................... 60,63 Pennington mine............................. 30

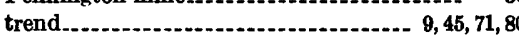

Trommald formation.......................... 73 Fort Ripley $\ldots . . . \ldots \ldots \ldots \ldots \ldots \ldots \ldots \ldots$ $\begin{array}{cr} & \text { Page } \\ \text { Fossils, Cretaceous. } & 11 \\ \text { Pleistocene._. } & \\ \end{array}$

Fractures.................................... 44-45, 45

G

Geosyncline, Precambrian...................... 9,32 Germanium content of iron-formation in the

Trommald formation........... 61

rift, Pleistocene........................... 3, 9,12

Glacial Lake Aitkin............................ 41

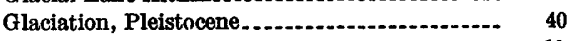

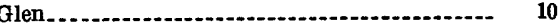

Gogebic district, Michigan........................ 56

Goodwin, A. M., quoted................. 32

Granules, thlek-bedded facies of Trommald

formation

Graywacke, Mahnomen formation............ 14

Griffin, Eli. -

Grout, F. F., quoted....................... 36, 39, 56

Gruner, J. W., cited...................... 31-32, 59

Guild, P. W., quoted....... 31

Gunflint district............................... 43

$\mathbf{H}$

Hanna Co., M. A. ........................ 6,8,69 Hanna Coal \& Ore Corp ...................... 70,

$75,76,79,80,81,82,83,84,85$

Hanna Iron Ore Co.................. 67, 69,71, 76, 77,85

Harder, E. C., cited........ 7, 56, 66, 68-69, 72,80, 83, 85

Hassman.

Hawalian basalt................................... 42, 48

Hill Mines Co........ 76

Himmrod, Anna, cited.......................... 5,6

Hobart Iron Co. of Pickands Mather \& Co..... 6

Holbrook, S. H., cited

Inland Steel Co.................... 6, 67, 71, 72, 73, 74 Iron content, schists of Rabbit Lake formation - $\quad 30$ Iron formation..................... 3, 9, 10, 46, 60,72,74

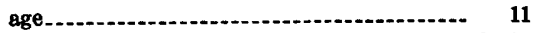
interpretation of the stratigraphy manganiferous........ 53-54,57 minerals. $48-49,53,55,61,69,70,71,73,75,79,80,82$

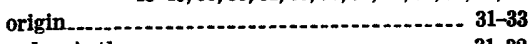
volcanic theory oxidized.................... 19, 33, $41,45,54,59,60$, $62,67,69,70,73,74,75,76,80,81,83,85,87$

unoxidized. $58-59,60,65,67,68,71,78,79,80,81,83,87$

veins

See also Rabblt Lake formation; Trommald formation.

Iron-formation geosyncline.................. $\quad 30$ Iron Mountain Mining Co ......... 68 Ironton

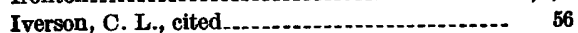
J

James, H. L., cited ___ 32,47, 56

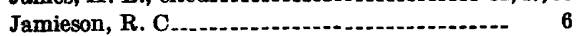
Jefferson Iron Mining Co..._................. 75 Jenkins Joan Mining Co........... 69, 83 Johnston, A. W., cited..... 7, 56, 66, 68-69, 72, 80, 83,85 Joints in iron-formation.......................... 45,51

June Lake.

36,46 


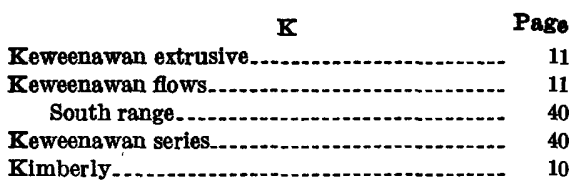

$\mathbf{L}$

Labrador-Quebec district, high-grade manganif-

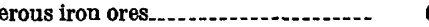

Lake Superior region. ............ 3, 5, 7, 19, 55, 56, 57,62 Leith, C. K., cited............... 7, 13, 31

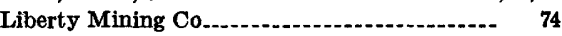
Limestone, Mahnomen formation............... 14, 30 Little Falls...................... 10

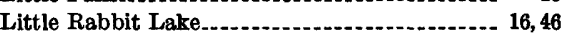
Location of area. Locker-Donahue Co Logs of drill holes, Northrange.............. 12-13,37

\section{M}

10 McGrath gneiss. Mahnomen formation. $11,12,14-18,25,30-31,35,38,39,40,44,45$, $47,63,66,70,76,77,78,79,82,84,85,86$; pls. $1,3$.

Mahnomen Mining Co. (Clement K. Quinn \& Co.)

Malmo_t_._. 10

Mangan Iron and Steel Co _............ 77,82

Manganese (village)

Manganese content, iron-formations at bedrock surface................. 53-54; pl. 9

Manganese reserves, low-grade............... 64-65

Mann, V. L., cited.... 56

Marquette district, Michigan................ 49, 55, 56

Marquette Ore Co-..-.......... 84

Maynard, J. E., quoted...................... 32

Menomin Lake.......... 18, 25, 29, 36, 38, 63, 54, 69, 81, 83

Merrimac Mining Co

Merritt Development Co........................ 69

Merritt-Joan No. 4-Ferro orebody, origin ....- 45-46

Mesabi district................ 3, 5, 7-8, 9, 10,11,13,14

$33,35,39,40,41,56,59 ;$ pl. 3

Biwabik iron-formatlon................... 32, 39

Metamorphism, igneous rocks.................... 48

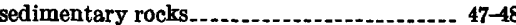

Michigamine, Mich....... 5

Milford mine disaster

Milford ore body

Mille Lacs Lake............... 10

Miller Lake.

Minerals:

acmite.... $20,44,45,69$

actinolite

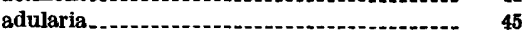

albite_................. 41, 45, 48

alunite

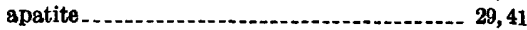

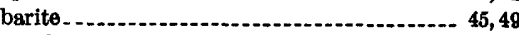

binghamite........................... 44

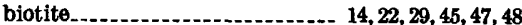

calcite............................ 14, $27,41,42,44,48$

carbon

carbonate

chert. $24,28,31,47,68,71,73,84,86$

corruginous -.... 20,26 chlorite.............. 14, 20, 22, 24, 29, 41, 42, 44, 47, 48 chloropal clinozoisite. copper, native............. 49 cryptomelane........................... 22, 44,49,84 diopside...................................... 45 edenite........................................ 41 epidote............................. 41,42,45, 48, 69 feldspar. . ........................................ 41, 48

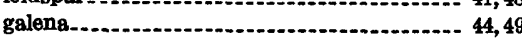

Minerals-Continued

goethite

Page

$22,44,48,49$,

22, 29, 44, 4

hematite $47,48,49,50,51,52,53,60,75,79,84$

hornblende.................................... 41, 42

itmenite

iron-ore.

iron oxide.

iron silicate.

jasper.

kaolin.

leucoxene.

magnetite

$14,20,22,24,41,47,48,49,55,64,80$

malachite........................... 49

manganese-ore ................. 48-48

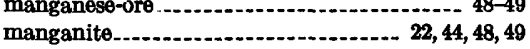

martite

microclin $\theta_{-}$

minnesotaite $\ldots . . . . . . . . . . . . . . . . . .20,44,47,48,59$

muscovite............................... 14, 27, 43,47,48

nontronite_............................. 22, 44, 48, 59

oligoclase....................................... 41, 48

orthoclase.

plagioclase_....................................... 14,41

psilomelane

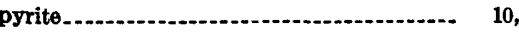

$14,15,26,27,29,30,33,42,44,49,75$

pyrolusite ....................... 22,44,49,80,84 pyrrhotite.................................. 10 quartz $\ldots . . . . . . .11,14,18,19,20,22,24,27,41$, $43,44,47,48,51,52,59,61,82,84$

rhodochrosite

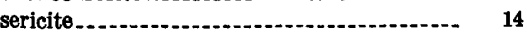
siderite............. 20, 22, 26, 29, 33, 44, 47, 48, 59, 80

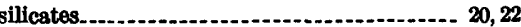
silver, native.................................. 49

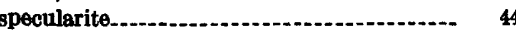
sphene................................... 41, 42,48 stilpnomelane ........... 20, 22, 28, 44, 45, 47, 48, 59 ferristilpnomelane....................... 24 tourmaline...................... 14, 20, 25, 44, 62, 76

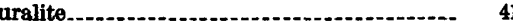
zircon, hyacinth............................. 14

Mines, Adbar mine. See Maroco mine.

Algoma... Alstead_._........... 15, 22, 36, 45, 57, 58; pl. 3 Alstead-North Hillerest open-pit..... 79, 82; pl. 3 Arko.............22, 36, 40,44, 46, 52, 58, 81, 82; pl. 3

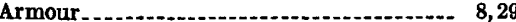
Armour No. 1.. 6 6, 26, 44, 46, 47, 52, 58, 60, 72, 73-74,

78; pls. 3, 7, 8

open-pit

6,73

sheft $48,72,74 ;$ pl. 3

Armour No. 2........27, 42, 43, 47, 49, 58, 59, 63, 70, 72-73, 74; pl. 3

open-pit_............ 43,46, 52, 71,72,73, 74; pl. 3 shaft........................ 48, 72; pl. 3 Bonnie Belle.................... 48, 63, 73,74; pl. 3 Carlson-Nelson open-pit................ 36, 85; pl. 4 Chisholm-Williams. See Portsmouth.

Clark. See Pontiac.

Croft._...................... 55, 58, 70; pl. 3

Cuyuna-Duluth mine. See Ironton.

Cuyuna-Mille Lacs. See Louise mine.

Cuyuna-Sultana. See Sultana mine.

Donahue. See Gloria.

Duluth-Brainerd. See Ferro.

East Feigh open-pit............

Evergreen. See Portsmouth.

Feigh $29,46,47,49,52,58,63,74,75-76,77$, pl. 3

Ferro ............................... 54,68-69; pl. 3

Gloria........................... 37, 54,67-68; pl. 3

Gorman open-pit, South range............... 3,10
Mines-Continued

Page

Healy. See Portsmouth.

Hillerest_.............................. 15, 76; pl. 3

Hillarest Extension open-pit................. 15,

Hoch. See Algoms

$22,54,58,59,79 ;$ pl. 3

Hopkins $41,52,80,83$

Huntington.......... 26, 27, 29, 47, 58, 63, 76-77; pl. 3

Huntington-Armour No. 1 group. 87

Ida. See Milford.

Iron Mountain. See Algoma.

Ironton. 48, 73, 74; pl. 3

Ironton shaft ....... 74

Joan

Joan No. 1 ........ 22, 24, 36, 38, 42, 43, 46, 52, 54, 83, 84

Joan No. 3 shaft. ..........

Joan No. 4_.................. 69; pl. 3

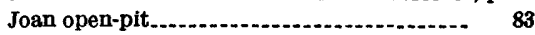

Kennedy ...................... 6, 63, 65-67; pl. 2

Liberty. See Bonnie Belle.

Louise..._................. 15, 52, 57, 58, 80; pl. 3 open-pit_................. 15, 22, 58, 80-81; pl. 3

McKenzie. See Gloria.

Mahnomen group..................... 58, 78, 79, 80 Mahnomen No. 1 open-pit_............... 15, $22,30,46,54,58,59,62,77,78-79$; pl. 3 See also Mangan No. 2

Mahnomen No. 2 open-pit .............. 22 ,

Mahnomen No. 3_.. 15, 22, 25, 54, 58, 78, 79, 82; pl. 3

Mahnomen No. 4 open-pit........... 78, 79-80; pl. 3

Mallen open-pit........ 27, 36, 42, 58, 59, 77, 85; pl. 4

Mangan-Joan open-pit.

Mangan No. 1............ 22, 42, 46, 80, 82-83; pl. 3 or Mangan-Stai open-pit........... 82-83; pl. 3

Mangan No. 2_................ 43, 46, 77-78; pls. 3, 8 open-pit. 77-78

Manuel open-pit.............................. 25, $27,42,43,52,53,62,69-70 ;$ pl. 3

South Yawkey property

West Airport property.............. 69

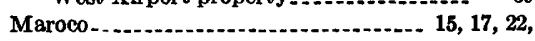

$27,29,35,38,42,43,48,49,54,84 ;$ pl. 3

Martin $\quad 16-17,58,62,77$; pl. 3

Meacham........................... 55, 70, 71; pl. 3

Meacham open-pit..

Merritt - 17

$20,24,35,36,37,38,46,52,68,69 ;$ pl. 3

Merritt No. 1....

Merritt No. 2......................... 69; 3

Milford................ 6, 44, 47, 67; pl. 2

North Hillerest open-pit..................... 22, $44,45,51,58,59,76,81,82$; pl. 3

North Yawkey open-pit............ 58, 65, 69; pl. 3

Northland. ........................ 30, 46, 67; pl. 2 property.

Osberg. See Portsmouth.

Pennington open-pit.......... 6, 27, 29, 30, 41, 43, $46,47,52,58,59,63,73,74-75 ;$ pl. 3 Pontiac, property...... 38

Portsmouth open-pit................. 25, 26, 33, 44, $45,47,50,63,54,58,59,70,71-72$; pls. 2,3

Preston shaft...... 54, 67; pl. 2 Rabbit Lake _ 25, 52, 54, 58, 59, 63, 67; pl. 2 Rowe open-pit:...... 6,15,36,43,46,54,77,85; pl. 4 Sagamore $15,16,20,22,25,33,36,41,45,46$.

Sagamore No. 1 open-pit_... $36,58,59,86,87$; pl. 4 Sagamore No. 2 open-pit.................... 15, 16, $22,29,30,36,49,50,52,62,86,87$; pl. 4 Section Six _...... 15, 17, 22, 27, 42, 43, 48, 64, 84; pl. 2 Sigma mine.

Snowshoe open-pit................ 57, 58-86; pl. 4 South Alstead. South Hillcrest open-pit.. $29,43,46,47,58,76$; pl. 3 Sultana _........................................ 80 Sultana-Hopkins open-pit_............ 78, 80; pl. 3 Syracuse open-pit.
Thompson. 
Mines-Continued

Page

Virginis open-pit...... 27, 28, 49, 54, 61, 84-85; pl. 3

Wearne open-pit. See Portsmouth.

Mining companies, active........................ 6,9 Minneapolis, St. Paul \& Sault Ste. Marie RR.. $\quad 5,6$ Minnesota, University, drill hole.......... 14-15, 25, 69 Minnesota County............................ 3 Mississippi River............................. 3, 7, 9, 29

Moore, E. S., quoted.......................... 32

Morrison County

Mrose, Mary, identification of unknown strontium-bearing mineral

\section{$\mathbf{N}$}

Northern Minnesota Ore Co

Northern Pacific Railway.

Onahman Iron $\mathrm{Co}$ Oneida Mines Co.

Oolites, iron-formation.

(1)

Open pits, maps

Ore, chemical analyses.

- 49-63

.

brown, in thick-bedded facies of Trommald formation................................... 58-59

gnarled, defined....................... 49 distribution............................ 53

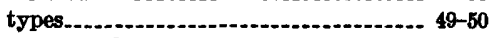
grades of North range........................ 49, 50

laminated, composition

occurrence, in Trommald formation, thickbedded facies...........................

in Trommald formation, thin-bedded facies.................... 57-60 in Rabbit Lake formation. ............ 61 origin of Cuyuna-type, proposed............ 61-62 theories. $55-57$ red-brown, in thick-bedded facies of Trommald formation........ 59-60

solution-banded.............................. 53

specular.............. 52-53 distribution................................ 53

texture............................ 49-53, 58, 60,75

\section{$\mathbf{P}$}

Paint rock. See Argillite.

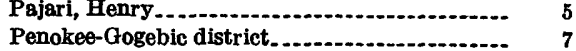

$\begin{array}{lr}\text { Penokee-Gogebic district. .......... } & 7 \\ \text { Philbrook. } & \end{array}$

Phosphorus content in Cuyuns ores......... 54-55,86

Phyllite, Mahnomen formation................. 14, 15 Rabbit Lake formation.................. 85

Pickands Mather \& Co........................ 6,86

Pittsburgh Steel Ore Co

Pleistocene conglomerates......................... 11

Pleistocene deposits............................... 40-41

Pleistocene ferruginous conglomerates.......... 40

Pleistocene glacial drift.................... 3, 9, 12, 37, 40

Pleistocene pebbles and boulders............... 37

Pokegama formation................... 8, 14, 36, 37, 38, 39

Pokegams quartzite of the Mesabi district.... 13, 38, 39

Population of villages.............................. 5

Portage Lake.

Potash content, sedimentary rocks of Rabbit formation................................ 27

Precambrian iron-formation, origin.............. 31-33

Production of ore.....

Algoma mine................ 68

Alstead, North Hillerest, Hillorest Extension

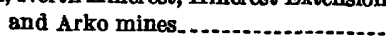

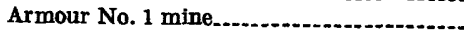

Armour No. 2 mines..........................

Croft mine.

Cuyuns district.

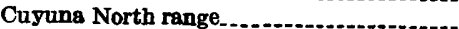

Ferro mine

Gloria mine.
Production of ore-Continued

Hopkins property.

Kennedy mine.

Louise mines.

Mahnomen group.

Mangan-Joan open-pit mine

Maroco mine.

Trojan property

Merritt mine

Milford mine.

Pennington mine

Sagamore mine

See also Shipment of ore.

Property ownership in Cuyuna district

\section{Q}

Quartz diorite

74

Quartz sand, Trommald formation............ 24-25, 83 Quartz siltstone, Mahnomen formation........... 11, 15 Quartzite._........................................... 36

Mahnomen formation.- $14,15,33,79,81,82,84,85$ Pokegama formation...................... 13, 38, 39 Rabbit Lake formation...................... 27

\section{$\mathbf{R}$}

Rabbit Lake................... 26, 29, 35, 41, 45, 63, 67 Rabbit Lake formation.......................... 11 $12,13,25,26-30,33,35,38,40,41,42,45$, $46,47,48,51,53,57,61,63,64,66,69,70$. $71,73,74,75-76,77-78,83-84,85,86,87$

black argillite and state...................... 27-28

chlorite and chlorite-biotite schist............ 29-30 Randall. .. 3, 10; pl. 1 Relief $3,5,11,40,62$

Reserves, low-grade manganese................. 64-65 Rhude and Fryberger. ..................... 6, 74, 85 Rhude, Fryberger, \& Leach....................... 85 Riverton.

Roches moutonnee of unoxidized thin-bedded Trommald formation................ 40

Rodgers-Brown Ore Co..................... 65.70,72,73

Royce, Stephen, cited....................... 8, 13, 59

\section{$\mathbf{s}$}

Sagamore Ore Mining Co..._.................. 86 St. Louis slates of Minnesota.................. 7 Sandstone, Mahnomen formation............. 14, 16, 82 Pokegama formation . . ...................... 38 Savage, John A., \& Co .......................... 70,86 Schist. $60,71,72,73,74,75$

Mahnomen formation ................. 14 Rabbit Lake formation....................... 14, $18-19,26,29-30,47,48,63,71,73,74,75-76,77$ Trommald formation................. 25, 26,33, 75 Schwartz, G. M., cited........................ 10 Shale.............................. 36, 37, 38, 43, 69, 75, 78 Mahnomen formation..................... 14, 16

Shipment of ore, Algoma mine.................. 68 Arko mine.

Armour No. 1 mine

Armour No. 2 mine..... 72

Croft mine.

Cuyung North range. 6,6

Feigh mine................................ 75

Ferro mine

Gloria mine.

Huntington mine.

Ironton mine.

Joan No. 4 mine.

Kennedy mine

Louise mine.

Mangan No. 1 mine

Mangan property --

Manuel-open-pit mine.

Martin mine.

Meacham mine

Merritt mine.
Shipment of ore-Continued

Page

Milford mine

North Yawkey open-pit mine

Northland stockpile

Pennington mine...-

Rabbit Lake open-pit mine................

Rowe open-pit mine

Section Six mine.

Snowshoe open-pit

South Hillcrest open-pit mine................ 85-86

Thompson mine

Virginia open-pit mine. .................

See also Production of ore.

Sills, basalt.

diabase

Martin mine

Siltstone__.

Mahnomen formation........... 14, 15, 16, 17, 85, 86

Slate, Mahnomen formation................ 15, $16-17,77,79,81,82,84,85$

manganiferous.

Pokegama formation

Rabbit Lake formation .................... 11 $18-19,26,27,30,75,76,77$

Trommald formation.................. 25, 33,47,75

Snyder Mining Co

South range......... 3, 4, 6, 8, 9, 11, 12, 13, 14, 38-39, 40, 55 fron-formation.............................. 18

Keweenawan flows........................ 40

Spencer, G. H., Jr., cited_..................... $\quad 56$

Staples.

Stylolites, thin-bedded facies of Trommald formation

Sulfur content, tuffaceous argillite of Rabbit Lake formation...-................... 27

Synclines................................ 17, 29,45-46

Algoma mine................................ 68

Alstead-North Hillcrest open-pit mine_..... 82

Arko mine_................................... 81

beneath Menomin Lake..................... 81

Ferro mine......................................... 68

Gloria mine............................... 37

Hillerest Extension open-pit mine.......... 79

Joan open-plt mine_.......................... 83

Louise mine_.................................. 80

Mahnomen No. 1 mine....................... 78,79

Mahnomen No. 2 open-pit mine............. 80

Mahnomen No. 3 mine..................... 79

Mahnomen No. 4 open-pit mine........... 79

major, in North range......................... 45-46

Mangan No. 1 open plt.................... 83

Mangan No. 2 mine._...................... 77

Manuel mine_................................ 69

Merritt mine_................................... 69

Merritt mine-Rabbit Lake................... 65

Milford mine.............................. 67; pl. 2

Northland mine_........................... 67

occurrence of ore bodies...................... 60,63

Portsmouth mine............................. 71

Rabbit Lake formation................. 29, 45, 73,78

Rabbit Lake mine............................ 67

Rowe open-pit mine._...... 85

Sagamore No. 1 open-pit..................... 87

Sagamore ore bodies......................... $\quad 86$

Snowshoe open-pit mine................... 86

Sultang-Hopkins open-pit mine-_-_........ $\quad 80$

Trommald formation..........................

Synclinorium, northeast-trending, Cuyuna dis-

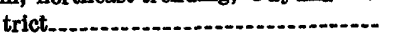

Thiel, G. A., quoted $\ldots \ldots \ldots \ldots \ldots$

Thomson formation.

at base.............................. 25,26

Rabbit Lake formation, schists_............ 30

rocks of North range.......................... 28, 33, 34

Trommald formation, argillaceous layers in thin-bedded factes..................... 25

tufi in North range.
3 
Page

Todd County..................... 3,

Tod-Stambaugh Co.......

Transportation

Transportation

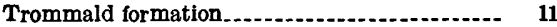

$12,13,15,18-26,31,33,35,38,39,40.42$, $44,45,46,47.50,51,52,53,54,57,65,66,70$, 75,77 ; pls. 1,6 .

recommendations for further exploration.... 62-63 thick-bedded facies.......................... 13 $20,22,24,29,31,33,39,60-61,62,63-64,66$, $68,69,77,79,81,82,83,84,85$; pls. 5,6 .

thin-bedded facies. ....................... 13

$20-22,33,38,40,57-60,61,63,66,67,68$, $69,70,71,73,74,76,77,78,79,81,82,83$ 86.

Tyler, S. A., cited.

Tuffs........... 9, 36, 38, 42-43

basaltic.

Rabbit Lake formation.................... 11, 26, 33
Twenhofel, W. H., cited..

U

U.S. Bureau of Mines..................... 10, 12,64,65

V

Van Hise, C. R., quoted

Veins.................................... 43-44, 49, 52,59 Mahnomen No. 2 open pit................ 81

quartz, Alstead-North Hillcrest open pit.... $\quad 82$

Vermillion district.................................. 41

Virginia formation...................... 8, 14, 33, 36, 38

Virginia slate.............................. 7, 10, 13, 39, 40

Volcanic ash.................................. 25, 31, 33

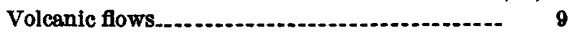

Wash ore, distribution.

upper iron-formation lenses of Rabbit Lake formation. age

White, D. A., quoted....................... 32,56

White, W. C...................................... 5

Whitmarsh Mining Co

Wolff, J. E., Sr., cited......... 8, 35-36, 39, 46, 56, 68

$\mathbf{x}$

$\mathbf{X}$-ray powder patterns, thin-bedded facies of Trommald formation.

$\mathbf{Y}$

Youngstown Mines Corp

Zapffe, Carl, cited...................... 5, 7-8, 13,67 Zontelli Bros., Inc........................... 69, 77,83,84 Zontelli Division of Pittsburgh Pacific Co...... 6,69 Zubovic, Peter, analyst......................... 61 


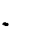


. 